
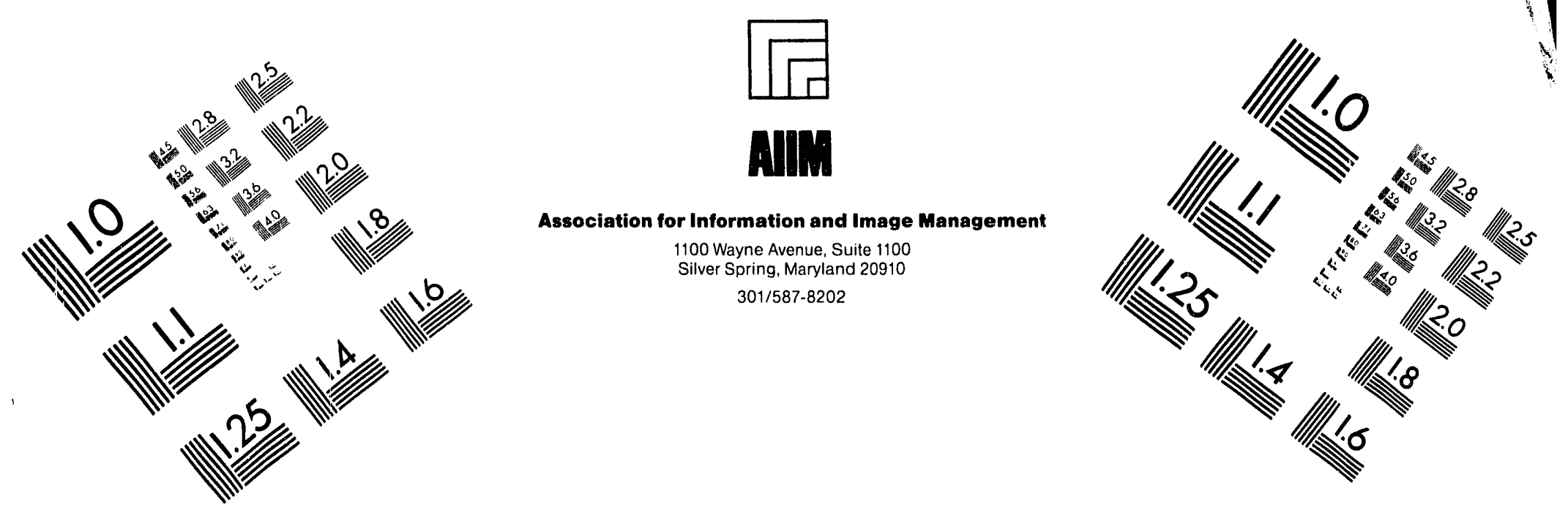

\title{
Centimeter
}

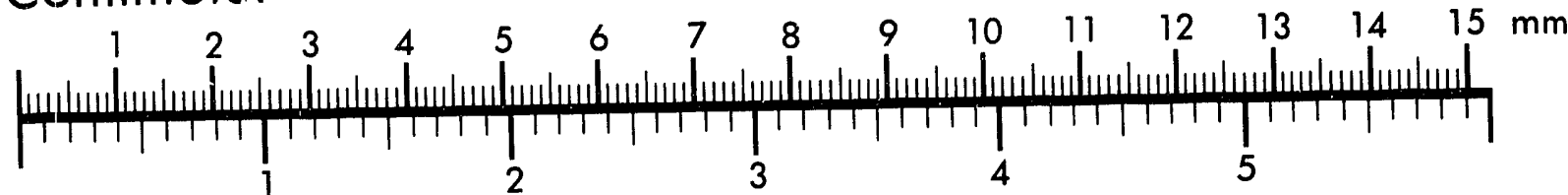

Inches
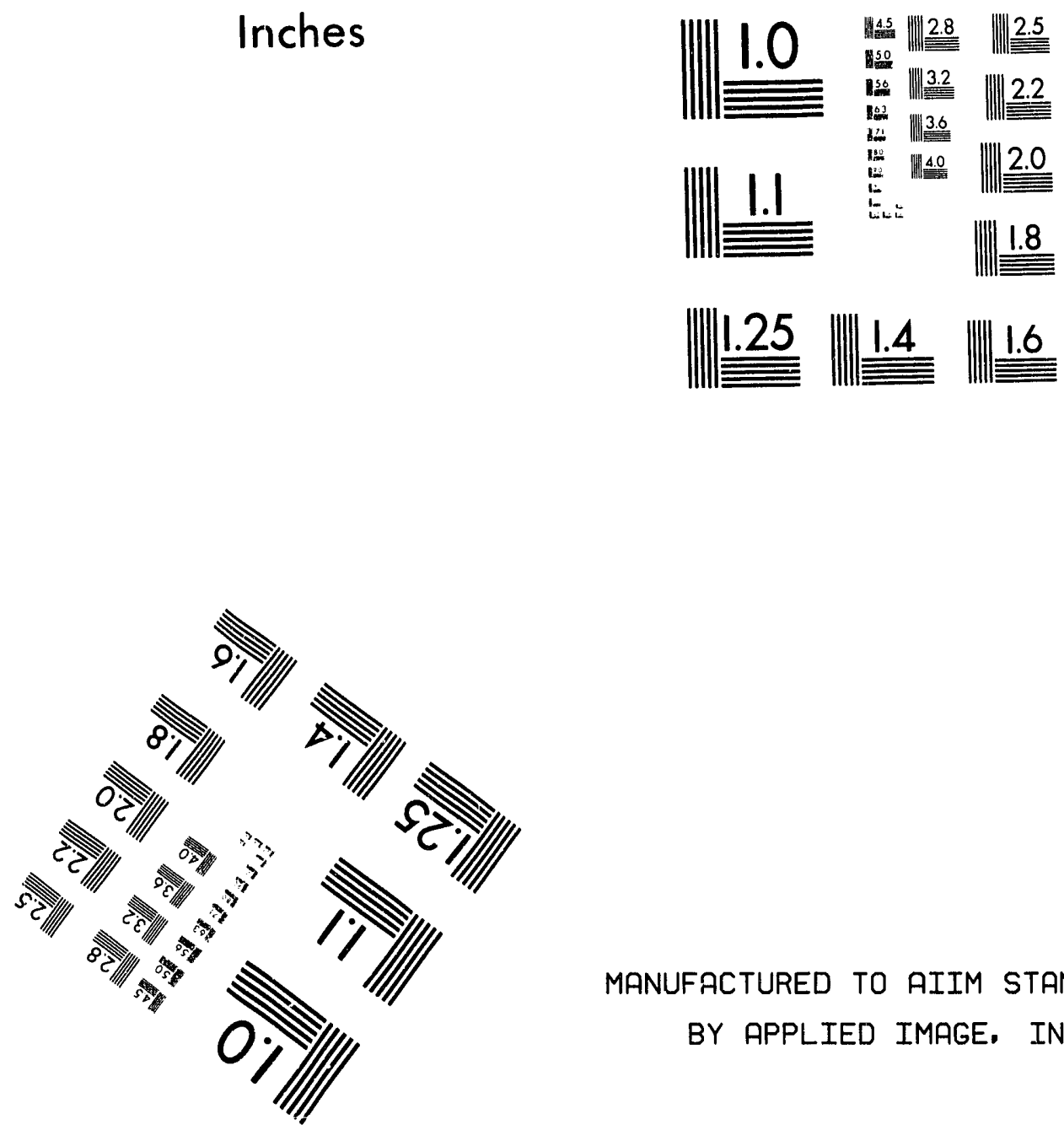

MANUFACTURED TO AIIM STANDARDS

BY APPLIED IMAGE, INC.

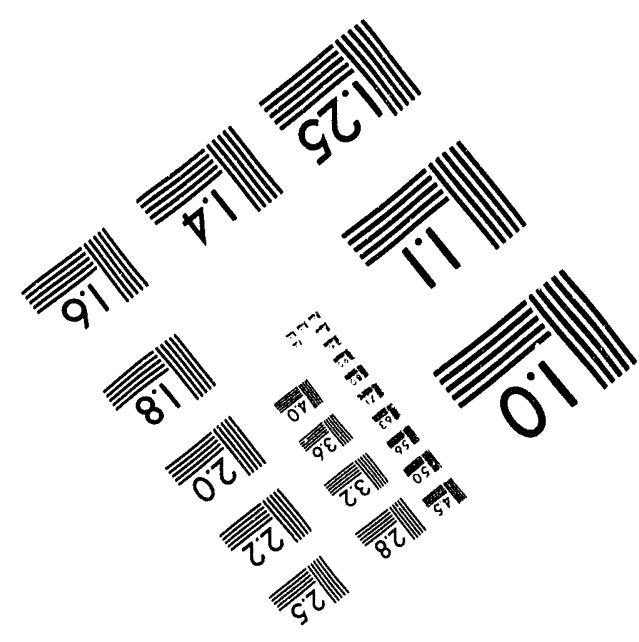



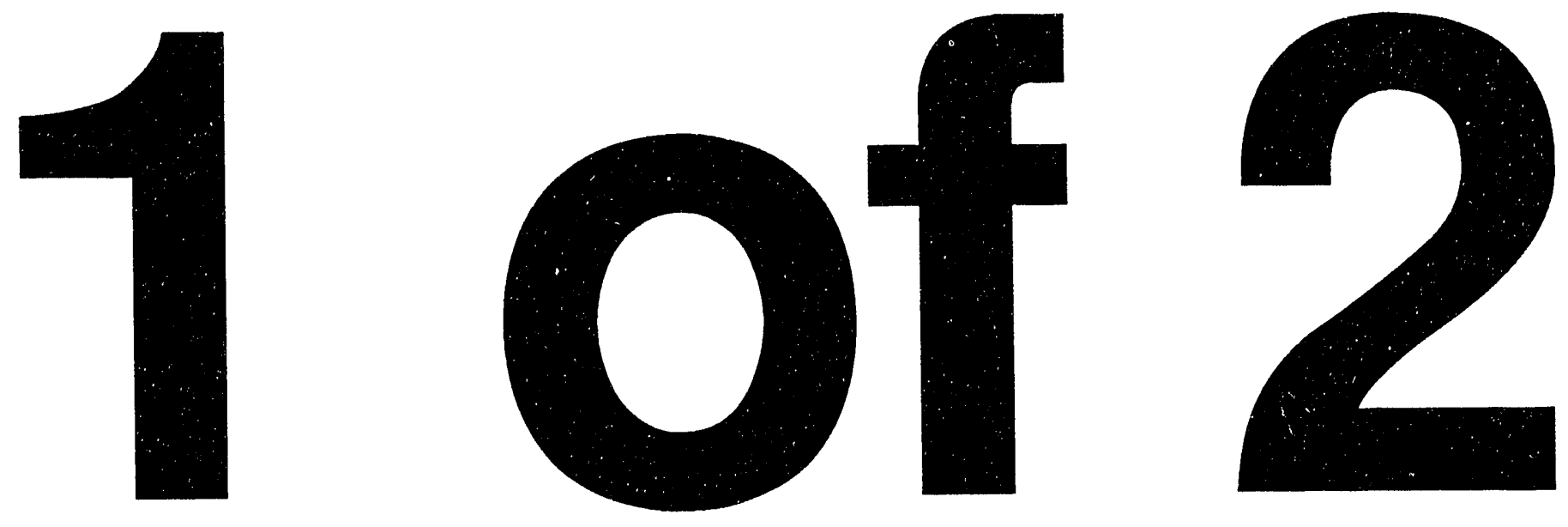


\title{
STATE OF NEVADA \\ AGENCY FOR NUCLEAR PROJECTS \\ NUCLEAR WASTE PROJECT OFFICE
}

\section{NWPO-TR-011-89 \\ THE RELATIONSHIP OF THE YUCCA MOUNTAIN REPOSITORY BLOCK TO THE REGIONAL GROUND-WATER SYSTEM: A GEOCHEMICAL MODEL}

\author{
by \\ Nancy A. Matuska \\ John W. Hess \\ Water Resources Center \\ Desert Research Institute \\ University of Nevada System \\ Las Vegas and Reno, Nevada
}

August 1989

\begin{abstract}
DISCLAIMER
This report was prepared as an account of work sponsored by an agency of the United States Government. Neither the United States Government nor any agency thereof, nor any of their employees, makes any warranty, express or implied, or assumes any legal liability or responsibility for the accuracy, completeness, or usefulness of any information, apparatus, product, or process disclosed, or represents that its use would not infringe privately owned rights. Reference herein to any specific commercial product, process, or service by trade name, trademark, manufacturer, or otherwise does not necessarily constitute or imply its endorsement, recommendation, or favoring by the United States Government or any agency thereof. The views and opinions of authors expressed herein do not necessarily state or reflect those of the United States Government or any agency thereof.
\end{abstract}

The Nevada Agency for Nuclear Projects/Nuclear Waste Project Office was created by the Nevada Legislature to oversee federal high-level nuclear waste activities in the state. Since 1985, it has dealt largely with the U.S. Department of Energy's siting of a high-level nuclear waste repository at Yucca Mountain in southern Nevada. As part of its oversight role, NWPO has contracted for studies of various tehcnical questions at Yucca Mountain.

This study was funded by DOE grant number DE-FG08-85-NV10461.

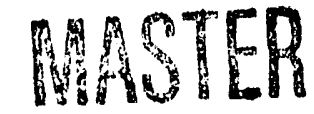




\begin{abstract}
Yucca Mountain, in southern Nevada, is being studied by the Department of Energy and the State of Nevada as the site of a high-level nuclear waste repository. Geochemical and isotopic modeling were used in this study to define the relationship of the volcanic tuff aquifers and aquitards to the underlying regional carbonate ground-water system. The chemical evolution of a ground water as it passes through a hypothetical tuffaceous aquifer was developed using computer models PHREEQE, WATEQDR and BALANCE. The tuffaceous system was divided into five parts, with specific mineralogies, reaction steps and temperatures. The initial solution was an analysis of a soil water from Rainier Mesa. The ending solution in each part became the initial solution in the next part. Minerals consisted of zeolites, smectites, authigenic feldspars and quartz polymorphs from described diagentic mineral zones. Reaction steps were ion exchange with zeolites. The solution from the final zone, Part V, was chosen as most representative, in terms of $\mathrm{pH}$, element molalities and mineral solubilities, of tuffaceous water. This hypothetical volcanic water from Part V was mixed with water from the regional carbonate aquifer, and the results compared to analyses of Yucca Mountain wells. Mixing and modeling attempts were conducted on wells in which studies indicated upward flow. These attempts suggest that volcanic water from well UE-25 $\mathrm{p}^{* 1}$ may be represented as $68 \%$ modeled tuffaceous water and $32 \%$ carbonate aquifer water. The hypothetical tuffaceous water of Part $\mathrm{V}$ appears to most represent well samples with high $\mathrm{pH}$ values, such as USW H-3 and USW WT-10. Wells with near-neutral $\mathrm{pH}$ values are not well represented by this model, and appear to show great influxes of water from the carbonate aquifer. This may be an erroneous result, caused by problems with the model involving kinetics, thermodynamic data, and mineral equilibrium. Isotope analyses of the Yucca Mountain wells suggest no upward flow from the carbonate aquifer, except in well USW $\mathrm{p}^{\#} 1$, and suggest that Forty Mile Wash might be a local zone of recharge.
\end{abstract}




\section{Table of Contents}

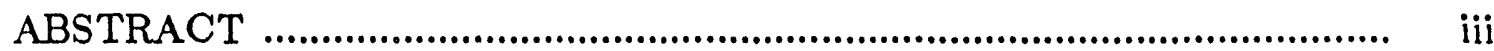

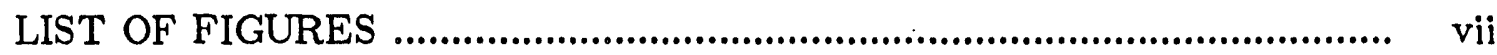

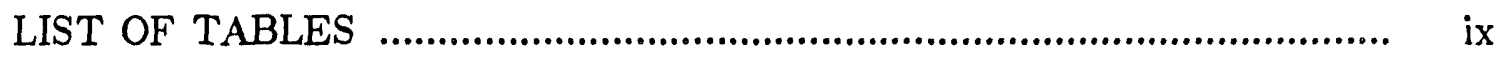

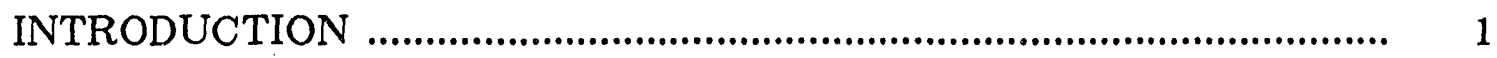

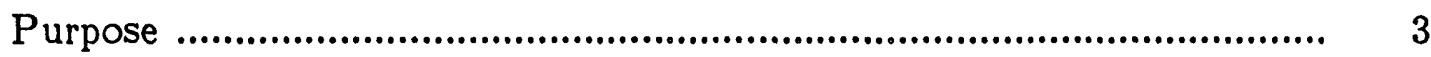

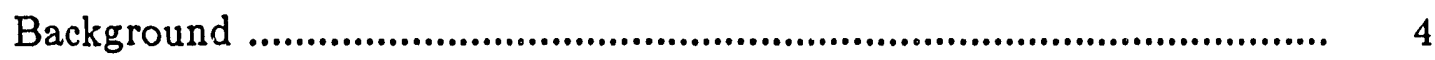

PREVIOUS INVESTIGATIONS _.......................................................... 7

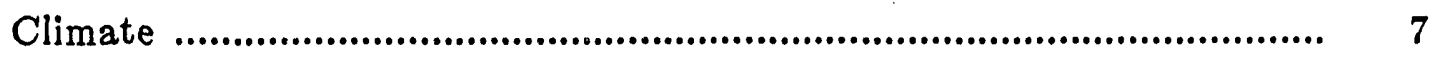

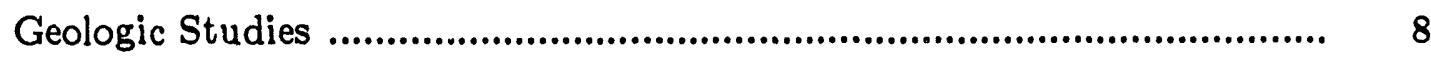

Pre-Cenozoic Tectonism and Geology .................................................. 11

Cenozoic Tectonism and Volcanism ..................................................... 12

Hydrologic Studies .............................................................................. 17

Lower Carbonate Aquifer ................................................................. 17

Volcanic Tuff Aquifers and Aquitards ................................................. 19

Valley Fill Aquifer ...................................................................... 20

Regional Ground-Water Flow Directions …........................................... 20

Ash Meadows Subbasin ....................................................................... 22

Alkali Flat - Furnace Creek Ranch Subbasin ................................... $\quad 22$

Ground-Water Flow Around Yucca Mountain ................................... 24

Ground-Water Chemistry ..................................................................... 26

Ground-Water Chemistry of Study Area ………….............................. $\quad 26$

Yucca Mountain Ground-Water Chemistry ....................................... $\quad 29$

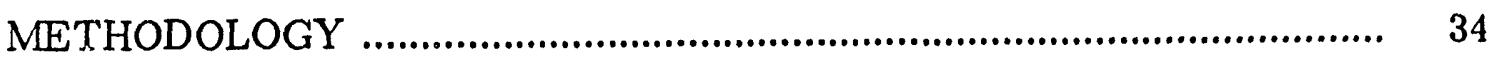

Literature Review ................................................................................. 34

Ground-Water Sampling .................................................................. 34

CONTROLS ON GEOCHEMISTRY ….................................................... 38

Influence of Volcanic Tuffs ......................................................................... 38 
Minerals Which Influence Chemistry _................................................ $\quad 39$

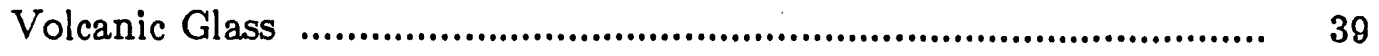

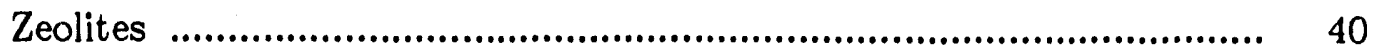

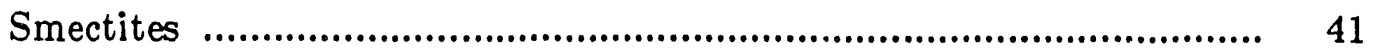

Diagenetic Mineral Zones ...................................................................... 42

GEOCHEMICAL COMPUTER MODELS …........................................ 46

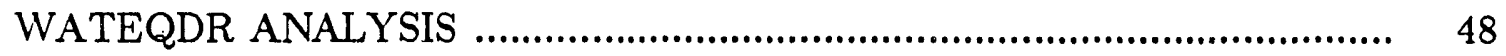

PHREEQE GEOCHEMICAL MODEL _.................................................. 61

Geochemical Model Input ............................................................................ 61

Geochemical Flow Path Model .............................................................. 63

Geochemical Modeling Results ............................................................... 67

MIXING MOḊELED VOLCANIC AND CARBONATE WATERS .............. $\quad 75$

Modeling Specific Wells ......................................................................... 75

Modeling Specific Well Results .................................................................. 76

Results From Well UE-25 p\#1 _.................................................. 77

Results From Wells USW H-3 And USW H-4 ................................. 79

Mixing Tuffaceous and Carbonate Waters in Set Ratios .......................... $\quad 80$

Mixing In Set Ratio Results .................................................................. 81

ENVIRONMENTAL ISOTOPES _............................................................... 83

Deuterium and ${ }^{18}$ Oxygen ....................................................................... 83

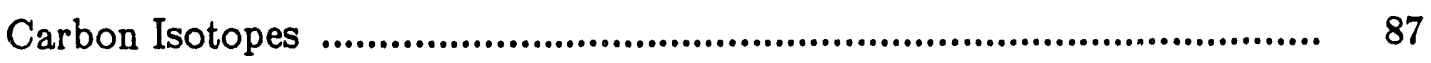

SUMMARY AND CONCLUSIONS …..................................................... 94

Conclusions From WATEQDR Analysis ................................................ 94

Conclusions From PHREEQE Model ...................................................... 95

Summary of Results ..................................................................... 95

Discussion of Errors in Modeling ...................................................... 96

Conclusions From I'sotope Analyses ................................................... 98

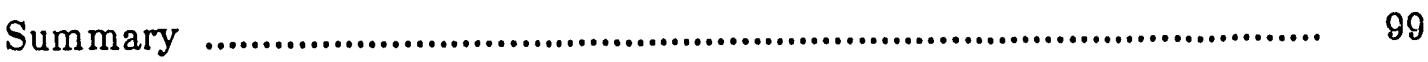

Additional Studies …............................................................................ 100

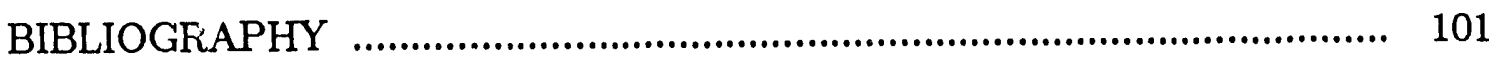




\section{APPENDIX A}

Data Base of Wells and Springs

Surrounding Yucca Mountain

APPENDLX B

Computer Listing of PHREEQE Flow Path and Mixing Models 


\section{LIST OF FIGURES}

Figure

Page

1. Location of Yucca Mountain and vicinity in southern Nevada.

2. Location of strike-slip and normal faults around Yucca Mountain, Nevada.

3. Ground-water flow directions within subasins of the Death Valley Ground-Water Basin in southern Nevada.

4. Location of wells with chemical and hydraulic analyses on

Yucca Mountain, Nevada.

5. Location of Yucca Mountain and data points in southern Nevada.

6. Diagenetic mineral zones of Yucca Mountain wells UE-25 b\# 1 and J-13.

7. Diager etic mineral zones of Yucca Mountain, Nevada.

8. Log activity of $\mathrm{H}_{4} \mathrm{SiO}_{4}$ and temperature of Yucca Mountain, Nevada, wells.

9. Mineral stability relationships of $\mathrm{Na}_{2} \mathrm{O}-\mathrm{K}_{2} \mathrm{O}-\mathrm{Al}_{2} \mathrm{O}_{3}-\mathrm{SiO}_{2}$ system at 1 bar pressure and $25^{\circ} \mathrm{C}$ and $37^{\circ} \mathrm{C}$.

10. Mineral stability relationships of $\mathrm{CaO}-\mathrm{Na}_{2} \mathrm{O}-\mathrm{Al}_{2} \mathrm{O}_{3}-\mathrm{SiO}_{2}$ system at 1 bar pressure and $25^{\circ} \mathrm{C}$ and $37^{\circ} \mathrm{C}$.

11. Sodium-potassium mineral stability relationships of wells and springs at 1 bar pressure and $25^{\circ} \mathrm{C}$ and $37^{\circ} \mathrm{C}$, of study area in southern Nevada.

12. Calcium-sodium mineral stability relationships of wells and springs at 1 bar pressure and $25^{\circ} \mathrm{C}$ and $37^{\circ} \mathrm{C}$, of study area in southern Nevada. 
13. Sodium-potassium mineral stability relationships of wells at 1 bar pressure and $25^{\circ} \mathrm{C}$ and $37^{\circ} \mathrm{C}$, Yucca Mountain, Nevada.

14. Calcium-sodium mineral stability relationships of wells at 1 bar pressure and $25^{\circ} \mathrm{C}$ and $37^{\circ} \mathrm{C}$, Yucca Mountain, Nevada.

15. Saturation index of Ca-montmorillonite compared to the partial pressure of $\mathrm{CO}_{2}$ along a flow path at Yucca Mountain, Nevada.

16. Chemical analyses of geochemical flow path modeled zones in volcanic aquifers around Yucca Mountain, Nevada.

17. Chemical anaylses of Yucca Mountain, Part V modeled zone and carbonate wells surrounding Yucca Mountain, Nevada.

18. Sodium-potassium mineral stability relationships of flow path model compared to Yucca Mountain, Nevada, wells at 1 bar pressure and $25^{\circ} \mathrm{C}$ and $37^{\circ} \mathrm{C}$.

19. Calcium-sodium mineral stability relationships of flow path model compared to Yucca Mountain, Nevada, wells at 1 bar pressure and $25^{\circ} \mathrm{C}$ and $37^{\circ} \mathrm{C}$.

20. Delta Deuterium and delta ${ }^{18}$ Oxygen values of Yucca Mountain, Nevada, wells.

21. Delta ${ }^{13}$ Carbon as a function of percent modern carbon of study area wells and springs in southern Nevada.

22. Delta ${ }^{13}$ Carbon as a function of percent modern carbon of Yucca Mountain, Nevada, wells. 


\section{LIST OF TABLES}

Table

1. Stratigraphic units underlying Yucca Mountain, Nevada.

2. Hydrologic units of Nevada Test Site.

3. Hydrogeology of wells surrounding Yucca Mountain, Nevada.

4. Diagenetic minerals of Yucca Mountain.

5. Thermodynamic data used in ground-water modeling.

6. Tuffaceous water chemistry zones modeled in PHREEQE.

64

7. Analyses of water table wells on Yucca Mountain, Nevada.

8. Comparison of Yucca Mountain wells analyses to PHREEQE flow path model: hydrochemical Part V analysis.

9. Comparison of UE-25 $\mathrm{p} \# 1$ sample analysis to UE-25 $\mathrm{p \# 1}$ from flow path mixing model using PHREEQE.

10. PHREEQE analyses of mixing Part $\mathrm{V}$ tuffaceous solution with carbonate aquifer water.

11. $\delta^{i 3} \mathrm{C}$ signatures of $\mathrm{CO}_{2}$ sources. 


\section{INTRODUCTION}

Yucca Mountain, Nevada, was selected as one of three possible sites for a high-level nuclear waste repository as part of the Nuclear Waste Policy Act of 1982, and targeted for further intensive study with the Nuclear Waste Policy Act Amendment of 1987. Yucca Mountain is located in southern Nevada, 105 $\mathrm{km}$ northwest of Las Vegas. The proposed repository site is on the east flank of Yucca Mountain on the southwest side of the Nevada Test Site (NTS) on three adjacent sections of Federal lands under the jurisdiction of the Department of Energy (DOE), the Air Force and the Bureau of Land Management (Figure 1).

The DOE's 1986 Environmental Assessment of Yucca Mountain required that a favorable condition which should be present at the proposed nuclear waste repository was a geohydrological system (which) can be readily characterized and modeled with reasonable certainty (DOE, 1986, p. 6-133). Due to a lack of available data, the DOE did not find this condition to be present at Yucca Mountain, although this area has been extensively studied by the DOE, U.S. Geological Survey (USGS), various national and local laboratories, and other agencies.

Hydrologic studies at Yucca Mountain indicate the ground-water flow to be controlled by both the Tertiary volcanic tuff aquifers and aquitards, and the underlying Paleozoic carbonate aquifer. Geochemical and isotopic modeling of the ground water, as presented in this study, is used to help define the vertical ground-water movement between the two units. 


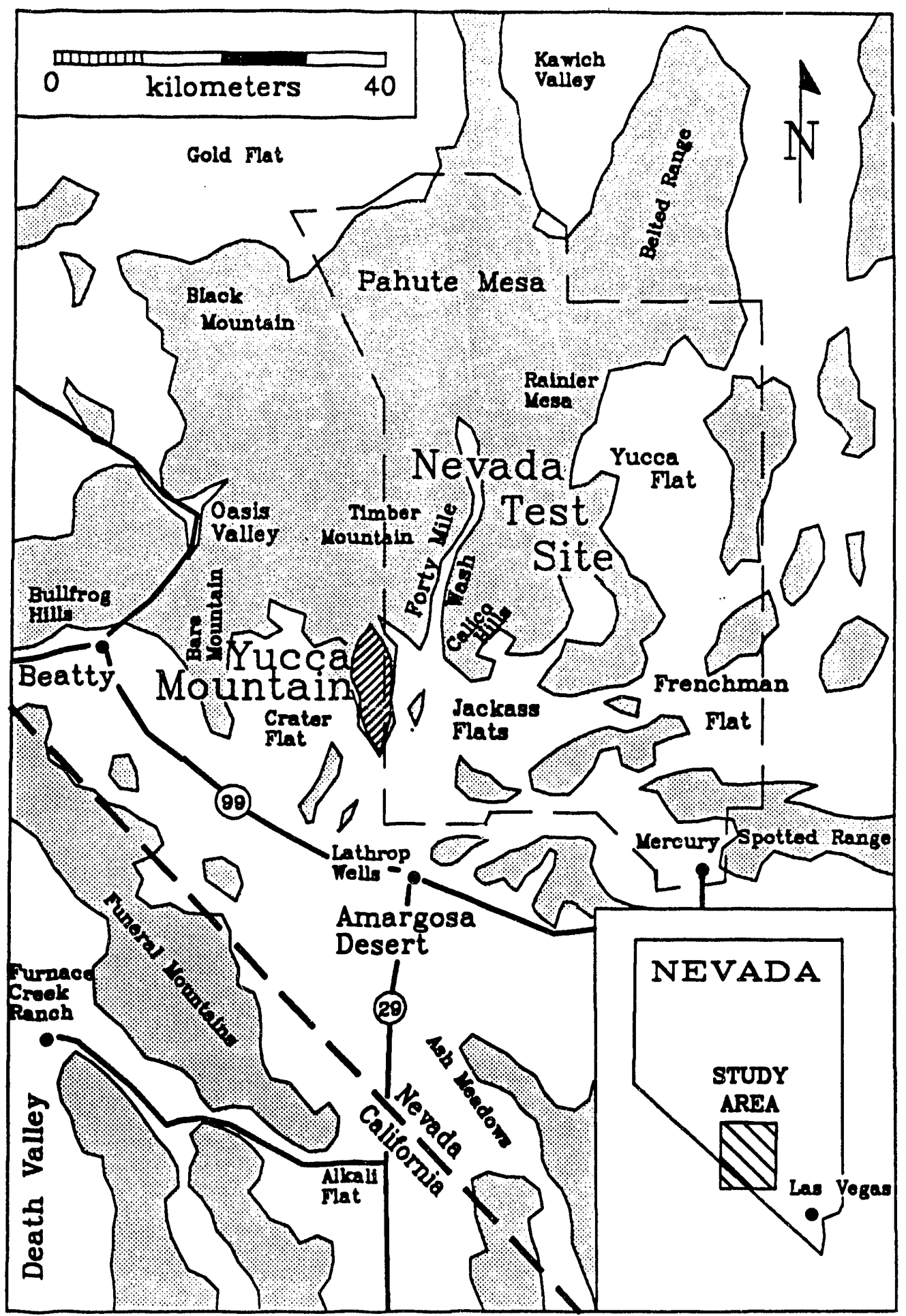

Figure 1: Location of Yucca Mountain and vicinity in southern Nevada. 


\section{Purpose}

The purpose of this study is to further define the possibility of upward flow of groundwater from the regional carbonate aquifer into the Tertiary volcanic tuffs. This is accomplished by incorporating a variety of hydrologic, geochemical and isotopic techniques which resulted in a flow path model for Yucca Mountain, which is compared to the DOE analysis of the area. The following steps are taken to reach this goal:

1. compilation of an extensive data base consisting of hydraulic, physical, chemical and isotopic data for water from wells and springs at Yucca Mountain and elsewhere in southern Nevada, collected from published literature;

2. collection of ground-water samples from the USGS water-table wells surrounding Yucca Mountain to augment the data base;

3. delineation of well waters into geochemical groups and determination of mineral equilibrium (what is potentially precipitating or dissolving) in each well;

4. geochemical modeling of the ground-water, which is assumed to move from a volcanic terrane into a carbonate terrane, and vice versa, using the computer models BALANCE, WATEQDR and PHREEQE, and analysis of the resultant watur chemistries;

5. comparison of these hypothetical waters to the data base water chemistries;

6. use of graphical and analytical methods to differentiate water groups on the basis of isotopic analysis, and comparison of these groups to the results of the geochemical flow path modeling. 


\section{Background}

Yucca Mnuntain was selected for further study by the DOE as a potential high-level nuclear waste repository in part because hydrologic and geologic conditions seem to indicate a low potertial for radionuclide transport. The rock type under consideration at the repository site is ash-flow and nonwelded to welded Tertiary volcanic tuff. Thick zeolitic layers are present within the tuffs. These may exchange cations and therefore may retard the movement of radionuclides.

The position of the putential repository horizon, within the Topopah Spring member of the Paintbrush Tuff, is 250 to $\mathbf{3 5 0}$ meters below land surface and 200 to 450 meters above the water table. Direct recharge from precipitation is estimated to be less than five millimeters per year. In the saturated zone, downward flow through the tuffs is believed to be of low quantity, less than 10 centimeters per year (Montazer and Wilson, 1984). There is evidence for possible upward flow from the carbonate aquifer occuring in one well, UE-25 $\mathrm{p}^{\#} 1$, and temperature gradients in other wells suggest upward flow, but not necessarily from the carbonate aquifer. Upward flow from the regional carbonate aquifer to the tuffs is viewed as a favorable condition for a nuclear waste repository, as this would limit the transport of radionuclides into the regional carbonate aquifer ground-water system.

Ground-water chemistry in a tuffaceous aquifer is believed to be controlled by the dissolution of volcanic glass, the removal of ions from solution through secondary mineralization of smectites, and cation exchange within zeolites. Water chemistry in a carbonate aquifer is a function of $\mathrm{P}_{\mathrm{CO}_{2}}$, calcite, dolomite and smectites. This results in a unique water chemistry in each type of aquifer.

Geochemical modeling is a process of simulating conditions expected to be present in a system and predicting what happens to such parameters as mineral equilibria, $\mathrm{pH}$ or $\mathrm{P}_{\mathrm{CO}_{2}}$. To model the geochemistry of ground-water at Yucca 
Mountain, a flow path through a tuffaceous aquifer was constructed using published lithologies of volcanic tuff. The volcanic tuffs are divided into a series of mineral zones designed to reflect the reaction (ion exchange or dissolution of volcanic glass) between various volcanic minerals and ground water.

The objectives of the geochemical modeling of this study are presented in the following questions:

1) Can the geochemistry of the ground water traveling through Yucca Mountain be modeled?

2) What happens to various minerals along the flow path through the tuffs?

3) What is happening to theoretical partial pressure of $\mathrm{CO}_{2}$ along the flow path, i.e., is this an open or closed system to atmospheric influence?

4) If modeled tuffaceous ground water is mixed with water from the regional carbonate aquifer, what happens with respect to mineral precipitation and dissolution?

5) How well do water samples from Yucca Mountain wells compare to the modeled tuffaceous ground water?

6) How does the ground water of Yucca Mountain and the model compare to ground waters in the study area of Pahute Mesa, Oasis Valley or the Amargosa Desert?

7) How do the results of this study compare to the DOE's assessment of the vertical ground-water flow between the tuffaceous and carbonate aquifers at Yucca Mountain?

The following report is divided into four sections: (1) the geologic history and previous hydrologic studies of Yucca Mountain; (2) the collection of data used in the study; (3) the controls and steps taken in constructing the 
geochemical computer model; and (4) a comparison of the results of the computer and isotopic models and their applicability to Yucca Mountain wells. 


\section{PREVIOUS INVESTIGATIONS}

The climate, geology, hydrology and chemistry of Yucca Mountain have been extensively studied by many agencies. A. review of these studies provides a basis for understand how the modeling problem is set up, and how the results compare with those of previous investigations.

\section{Climate}

Yucca Mountain and vicinity have been classified as a low latitude desert, which is primarily the result of physiography. The Sierra Nevada Mountains to the west impede the movement of moisture-bearing Pacific air masses, causing a "rainshadow" effect. Precipitation averages $15 \mathrm{~cm}$ per year, 7-15 cm in the valleys and less than $25 \mathrm{~cm}$ on the ridges (Houghton et al., 1975; Winograd and Thordarson, 1975). The amount of annual recharge at Yucca Mountain by precipitation is estimated at 0.5 to $4.5 \mathrm{~mm} / \mathrm{yr}$ (Montazer and Wilson, 1984), and is a function of the amount, type and distribution of precipitation, conditions at time of snowmelt, moisture content of the soil, type of vegetation and topography (Waddell et al., 1984). The annual potential evapotranspiration is estimated to be 5 to 25 times greater than precipitation (Winograd and Thordarson, 1975).

.PP The primary sources of precipitation in southern Nevada are the Pacific frontal systems, which generally occur from October to May, and the Great Basin lows, which occur from April to June. (Houghton et al., 1975). These low pressure systems bring strong winds and moisture from the Pacific; but while the 
Pacific fronts are more frequent, the Great Basin lows are the chief source of winter precipitation because they generally remain stationary for several days at a time (Spaulding, 1985).

Surnmer precipitation, which accounts for 25 percent of annual NTS precipitation (Spaulding, 1985), occurs as localized thunderstorms. These high intensity, short duration storms are the result of convection heating of air over the valleys and subsequent cooling of this air as it moves over mountain ranges. The sources of moisture for these storms are subtropical highs which push moist air masses up from the Gulf of Mexico and Gulf of California.

The distribution of precipitation over southern Nevada may be divided into two zones of relative moisture quantity (French, 1983). The western side of southern Nevada falls within the moisture deficit zone defined by a lack of winter precipitation due to the rainshadow effect. The eastern side of southern Nevada has a moisture excess relative to the western side, receiving both summer and winter precipitation. The NTS lies within the transition zone between the two. Parts of the NTS, particularly the western highlands, may be considered as part of the excess zone, whereas the lower elevations may be considered deficit. Yucca Mountain is considered part of the deficit zone (French, personal communications, 1988).

\section{Geologic Studies}

Ground-water flow directions and chemistry are in part a function of structure and rock lithologies present along the flow path. The stratigraphy of Yucca Mountain consists of Paleozoic sediments unconformably overlain by Tertiary volcanic sequences. Quaternary alluvium blankets the intermontane valleys. Table 1 gives the stratigraphic sequence and lithology of the units present beneath the Yucca Mountain area. 


\begin{tabular}{|c|c|c|c|}
\hline \multicolumn{4}{|c|}{$\begin{array}{c}\text { TABLE } 1 \\
\text { STRATIGRAPHIC UNITS UNDERLYTNG YUCCA MOUNTAIN, NEVADA }\end{array}$} \\
\hline $\begin{array}{l}\mathrm{AGE} \\
(\mathrm{m} \cdot \dot{\mathrm{y}})^{1}\end{array}$ & FORMATION & MEMBER & LITHOLOGY \\
\hline $\begin{array}{l}\text { Quaternary - } \\
\text { Tertiary }(0-3)\end{array}$ & VALLEY FILL & & $\begin{array}{l}\text { Alluvial fan, fanglomerate, lakebed and } \\
\text { fluvial deposits. }\end{array}$ \\
\hline \multirow[t]{3}{*}{$\begin{array}{l}\text { Tertiary } \\
\text { Miocene (12) }\end{array}$} & PAINTBRUSH TUFF & Tiva Canyon & $\begin{array}{l}\text { Compound cooling units of ash-flow tuff; } \\
\text { nonwelded vitric base, welded, devitrified } \\
\text { interior. }\end{array}$ \\
\hline & & Yucca Mountain & $\begin{array}{l}\text { Ash-flow tuff; nonwelded vitric edges, } \\
\text { partially welded devitrifled interior. }\end{array}$ \\
\hline & & Pah Canyon & Nonwelded and vitric ash-flow tuff. \\
\hline (13) & & Topopah Spring & $\begin{array}{l}\text { Compound cooling units of ash-flow tuff. } \\
\text { Nonwelded to vitrophyric at top and } \\
\text { base, welded, devitrified interiors. Zeol- } \\
\text { ites present in basal units. }\end{array}$ \\
\hline \multirow[t]{2}{*}{$(13.4)$} & TUFF OF CALICO HILLS & (informal) & $\begin{array}{l}\text { Nonwelded to partially welded ash-flow } \\
\text { tuff; highly zeolitic, except for vitric } \\
\text { southern region. }\end{array}$ \\
\hline & CRATER FLAT TUFF & Prow Pass & $\begin{array}{l}\text { Ash-flow tufi with nonwelded top and } \\
\text { base and devitrifled interior. Nonwelded } \\
\text { zones are generally zeolitic. }\end{array}$ \\
\hline$(13.5)$ & & Bullfrog & $\begin{array}{l}\text { Compound cooling units of ash-flow } \\
\text { tuffs. Nonwelded top and base, non- to } \\
\text {-densely welded interior. Nonwelded } \\
\text { wones are zeolitic. }\end{array}$ \\
\hline \multirow[t]{4}{*}{ (15) } & & Tram & $\begin{array}{l}\text { Compound cooling units of ash-flow tuff; } \\
\text { degree of welding is variable. Zeolitic in } \\
\text { nonwelded zones, devitrifled in welded } \\
\text { zones. }\end{array}$ \\
\hline & DACITE FLOW BRECCIA. & & $\begin{array}{l}\text { Flow breccia, lava and tufis with zeolitic } \\
\text { zones. }\end{array}$ \\
\hline & LITHIC RIDGE TUFF & & $\begin{array}{l}\text { Non- to -moderately welded devitrifled } \\
\text { ash-flow tuff with zeolitic horizons. }\end{array}$ \\
\hline & $\begin{array}{l}\text { OLDER TUFF UNITS } \\
\text { (UNNAMED) }\end{array}$ & & $\begin{array}{l}\text { Dacitic to rhyolitic ash-flow tuffs, lavas, } \\
\text { and reworked volcanic sediments. Some } \\
\text { zeolitic horizons present. }\end{array}$ \\
\hline $\begin{array}{l}\text { Cretaceous to } \\
\text { Permian (67) }\end{array}$ & GRANITIC STOCKS & & $\begin{array}{l}\text { Granodiorite and quartz monzonite } \\
\text { stocks, dikes and sills. }\end{array}$ \\
\hline
\end{tabular}




\begin{tabular}{|c|c|c|c|}
\hline \multicolumn{4}{|c|}{$\begin{array}{c}\text { TABLE } 1 \text { continued... } \\
\text { STRATIGRAPHIC UNITS UNDERLYTNG YUCCA MOUNTAN, NEVADA }\end{array}$} \\
\hline $\begin{array}{l}\text { AGE } \\
(\mathrm{m} \cdot \mathrm{y} .)^{1}\end{array}$ & FORMATION & MEMBER & LITHOLOGY \\
\hline $\begin{array}{l}\text { Permian- } \\
\text { Pennsyl- } \\
\text { vanian }\end{array}$ & \multicolumn{2}{|l|}{ TIPPIPAH LIMESTONE } & Limestone \\
\hline $\begin{array}{l}\text { Mississippian } \\
\text { - Devonian } \\
\end{array}$ & \multicolumn{2}{|l|}{ ELEANA FORMATION } & $\begin{array}{l}\text { Argillite, quartzite, limestone } \\
\text { and conglomerate. }\end{array}$ \\
\hline \multirow[t]{2}{*}{ Devonian } & \multicolumn{2}{|l|}{ DEVILS GATE LIMESTONE } & $\begin{array}{l}\text { Limestone, dolomite, and } \\
\text { minor quartzite. }\end{array}$ \\
\hline & \multicolumn{2}{|l|}{ NEVADA FORMATION } & Dolomite \\
\hline \multirow{2}{*}{$\begin{array}{l}\text { Devonian } \\
\text { Silurian }\end{array}$} & \multicolumn{2}{|l|}{ LONE MOUNTAIN DOLOMITE } & Dolomite \\
\hline & \multicolumn{2}{|l|}{ ROBERTS MOUNTAIN FM } & Limestone and limey dolomite. \\
\hline \multirow[t]{5}{*}{ Ordovician } & \multicolumn{2}{|l|}{ ELY SPRINGS DOLOMITE } & Dolomite \\
\hline & \multicolumn{2}{|l|}{ EUREKA QUARTZITE } & $\begin{array}{l}\text { Quartzite with minor lime- } \\
\text { stone. }\end{array}$ \\
\hline & \multirow[t]{3}{*}{ POGONIP GROUP } & Antelope Valley Ls & Limestone and silty limestone. \\
\hline & & Ninemile Formation & $\begin{array}{l}\text { Interbedded claystone and } \\
\text { limestone. }\end{array}$ \\
\hline & & Goodwin Limestone & Limestone \\
\hline \multirow[t]{7}{*}{ Cambrian } & \multirow[t]{3}{*}{ NOPAH FORMATION } & Smokey & Dolomite, limestone \\
\hline & & Halfpint & $\begin{array}{l}\text { Limestone, dolomite and silty } \\
\text { limestone. }\end{array}$ \\
\hline & & Dunderberg Shale & Shale, Limestone \\
\hline & \multirow[t]{2}{*}{ BONANZA KING } & Banded Mountain & $\begin{array}{l}\text { Dolomite, limestone and minor } \\
\text { siltstone. }\end{array}$ \\
\hline & & Papoose Lake & $\begin{array}{l}\text { Limestone, dolomite and } \\
\text { minor siltstone. }\end{array}$ \\
\hline & \multicolumn{2}{|l|}{ CARRARA FORMATION } & $\begin{array}{l}\text { Interbedded siltstone and } \\
\text { limestones. Upper half is pri- } \\
\text { marily limestone. }\end{array}$ \\
\hline & \multicolumn{2}{|l|}{ ZABRISKIE QUARTZITE } & Quartzite \\
\hline \multirow[t]{3}{*}{ Precambrian } & \multicolumn{2}{|l|}{ WOOD CANYON } & $\begin{array}{l}\text { Quartzite,siltstone, shale, and } \\
\text { minor dolomite. }\end{array}$ \\
\hline & \multicolumn{2}{|l|}{ STIRLING QUARTZITE } & Quartzite, siltstone. \\
\hline & \multicolumn{2}{|l|}{ JOHNNIE FORMATION } & Quartzite, sandstone, siltstone, \\
\hline
\end{tabular}

Modified From: Robinson, 1985; Broxton et al, 1986

1 Million Years Ago 


\section{Pre-Cenozoic Tectonism and Geology}

Based on extrapolation of outcrops and aeromagnetic studies, a thick sequence of paleosediments is believed to be present beneath Yucca Mountain (Robinson, 1985). These sediments consist of Silurian to Mississippian sedimentary rocks which become younger to the south, and are folded into a large-scale, north-plunging syncline. Yucca Mountain is located over a small, northeastplunging subordinent syncline on the western limb of this larger fold (Sinnock, 1982, Robinson, 1985).

The Paleozoic carbonates encountered in drillhole UE-25 $\mathrm{p}^{\#} 1$, which is located on the eastern flank of Yucca Mountain, are the Silurian Lone Mountain Dolomite and the Roberts Mountain Formation. These formations are finely crystalline bedded dolomite with calcite and chert stringers (Carr et al., 1986) and are part of the lower carbonate aquifer which controls regional ground-water flow. Within the carbonate rocks, interstital porosity is low, thus permeability is along secondary fractures.

Sediments of this aquifer are part of the miogeosynclinal strata of the Cordilleran geosyncline deposited during late Precambrian and early Paleozoic eras. They consist of up to $11,300 \mathrm{~m}$ of dolomites, limestones and siltstones, with calcite, dolomite, chert, fluorite, pyrite and iron-magnesium oxides present in the fractures (Winograd and Thordarson, 1975).

During Mississippian time, the Antler Orogeny thrust marine sediments eastward, creating a highland from which detritus is shed into a marine foreland basin (USGS, 1984). These sediments form the Paleozoic aquitard strata of argillites, conglomerates, and quartzites of the Eleana Formation. Further deposition of marine shelf carbonate rocks occurred during Pennsylvanian and early Permian time (USGS, 1984). 
The next major orogenic event to influence the rocks of the study area is the Cordilleran Orogeny 195 to 80 m.y. (Robinson, 1985). During this time, the paleosediments were gently folded, and in some instances, thrust faulted. Segments of the CP thrust, a mid-Cretaceous age thrust which moved older rocks east-southeast over the younger Mississippian Eleana Formation (Carr, 1984), are exposed along the west side of Yucca Flat, in the Spotted Range, Bare Mountain, the Calico Hills and Death Valley.

During the Late Jurassic to early Late Cretaceous, the Sevier Arch, extending from southeast Nevada to western Utah, prevented any depositon of Mesozoic sedimentary rocks in the study area (Winograd and Thordarson, 1975). Mesozoic rocks present are mid-Cretaceous granite intrusives beneath Bare Mountain, Bullfrog Hills, Yucca Flat and, based on geophysical surveys, possibly the Calico Hills and Yucca Mountain (Winograd and Thordarson, 1975; Carr, 1984; USGS, 1984). Conjecture exists as to whether or not the granitic stocks under Yucca Mountain might actually be metamorphosed Eleana Formation (USGS, 1984).

\section{Cenozoic Tectonism and Volcanism}

The geology of the Yucca Mountain repository block itself is a result of the great amount of volcanic and tectonic activity which occurred during the Cenozoic era. During the late Mesozoic to mid-Cenozoic (100 - 10 m.y.), the Walker Lane Tectonic Belt was active. This is a northwest-trending, 100-km- wide zone of right-lateral shear extending from Texas to Oregon (Carr, 1984). Yucca Mountain and vicinity are located within this belt; a younger extension is the Las Vegas Valley Shear Zone. Total displacement along this zone may be 130 to $190 \mathrm{~km}$ (USGS, 1984). Proximal to Yucca Mountain, the Walker Lane Belt is expressed as right lateral shear, and is one of the least tectonically active zones 
in the Great Basin.

The Walker Lane Belt is the source of middle and late Miocene silicic volcanism in southwestern Nevada (Carr, 1984). This may be due to "leaky" transform faulting where volcanic centers are located on northeast trending zones of Tertiary crustal spreading (Weaver and Hill, 1979). The silicic volcanic activity appears to be concentrated where large right-lateral faults die out or split into branches or en-echelon arrangements (USGS, 1984).

Cenozoic volcanism began in central Nevada about late Eocene tima and spread southward, erupting within the Yucca Mountain area 16 to $7.5 \mathrm{~m} . \mathrm{y}$. (Carr, 1984; USGS, 1984). This volcanic activity deposited thick sequences of ash-fall tuffs, rhyolites, rhyodacites and lavas up to $4500 \mathrm{~m}$ thick beneath Pahute Mesa; less to the south (Winograd and Thordarson, 1975).

Five large calderas resulting from middle Miocene volcanic activity are located in the study area: Crater Flat-Prospector Pass, Silent Canyon, Claim Canyon, Timber Mountain and Oasis Valley calderas. There is evidence for an older caldera beneath Yucca Mountain (Carr, 1984). Approximately 11 to 8.5 m.y., volcanism changed from predominantly silicic to basaltic along rift-like structures localized in the Death Valley-Pancake Range Basalt Belt. This is a relatively youthful zone of slightly higher than regional tectonic activity (Carr, 1984; USGS, 1984). The basaltic cinder cones of Crater Flat are part of this zone and were erupted one million years ago (Carr et al., 1983) or more recently. There is speculation that the basaltic cinder cone of Lathrop Wells may be late Pleistocene or Holocene in age (Wells, 1988).

The Miocene volcanics, in which the Yucca Mountain repository block is located, are high silica rhyolites and quartz latites that are $3 \mathrm{~km}$ thick at the northern end of Yucca Mountain and pinch out approximately $22 \mathrm{~km}$ to the south (Robinson, 1985). They were deposited predominantly as multiple ash- 
flow sheets that constitute one compound cooling unit. Generally the top and base of the flows are nonwelded, vitric, and may contain pumice, glass shards and lithic fragments. The interiors of the flows are generally welded and devitrified, and may have vapor-phase crystallization. Vitrophyric zones are often present between the welded and nonwelded zones. Compositional variations within each ash-flow sheet are thought to record, in inverse order, the compostitional sequences that were established in the magma chamber prior to eruption (Lipman et al., 1966).

The lithology of a "typical" unaltered rhyolite from Yucca Mountain consists of 1 to 20 percent phenocryts of sanidine, oligoclase, quartz, biotite, minor clinopyroxene and oxides, plus lithic fragments, pumice and glass shards in a fine-grained groundmass of alkali feldspar - plagioclase - quartz - perlite (Bish et al., 1982). A description of each volcanic unit may be found in Table 1 and a thorough discussion of the lithology of Yucca Mountain volcanics may be found in Bish et al., 1982 and Broxton et al., 1986.

Diagenetic alteration has affected most of the volcanic rocks, especially those below the water table. Paleowater tables and/or zones of perched water may be inferred from secondary mineralization zones. The principal alteration products present in the volcanic rocks are zeolites, smectites and authigenic feldspars which replace volcanic glasses, pumice, and primary feldspars. Diagenetic alteration is best developed in the groundmass and phenocrysts of the nonwelded sections of the cooling units (Broxton et al., 1986), and as fracture coatings in the welded tuffs (Carlos, 1985).

Approximately 17 m.y., Basin and Range extensional tectonism began, resulting in the formation of the long, linear, north-striking horst and graben topography prevalent today. These high-angle normal faults often occur along reactivation of caldera ring fractures and tend to flatten with depth. Nearly all 
extensional faulting has occurred by reactivation of existing faults. The present-day topography of the study area was influenced by both Cenozoic volcanism and Basin and Range faulting.

The Yucca Mountain repository block has typical Basin and Range topography of tilted mountain blocks bounded by antithetic normal faults. To the north of Yucca Mountain is a highly faulted and eroded volcanic plateau. Yucca Mountain is on the southern boundary of this plateau and is bounded on three sides by faults. The geomorphology of Yucca Mountain is controlled by two sets of faults. The first set consists of Basin and Range-type, high-angle, normal faults striking north-northeast. Ghost Dance, Solitario Canyon, Dune Wash, Bow Ridge, Paintbrush Canyon, Fatique Wash and Abandoned Wash faults (Scott and Bonk, 1984) are the larger faults of this set. The second set consists of faults which are at the northern end of Yucca Mountain and are a series of northwest-trending, right-lateral, strike-slip faults. Yucca Wash, Pagany Wash, Sever Wash and Drill Hole Wash faults are examples, and may be from reactivation of the Walker Lane Belt. Figure 2 shows the location of the major faults of these sets. Some minor late Fleistocene movement has occurred in the vicinity of Yucca Mountain; however, no unequivocal displacement of Holocene deposits has been discovered (USGS, 1984). Knowledge concerning fault locations is important in ground-water modeling, as the faults may be either conduits or barriers to ground-water flow.

The Quaternary alluvial deposits in the study area are fanglomerate, alluvial fan, lakebed and fluvial detritus shed from the mountain ranges, and may attain thicknesses greater than $2000 \mathrm{~m}$ in the centers of valleys (Winograd and Thordarson, 1975). The composition of the alluvium is a function of the lithology of the source rock and distance of transport. 


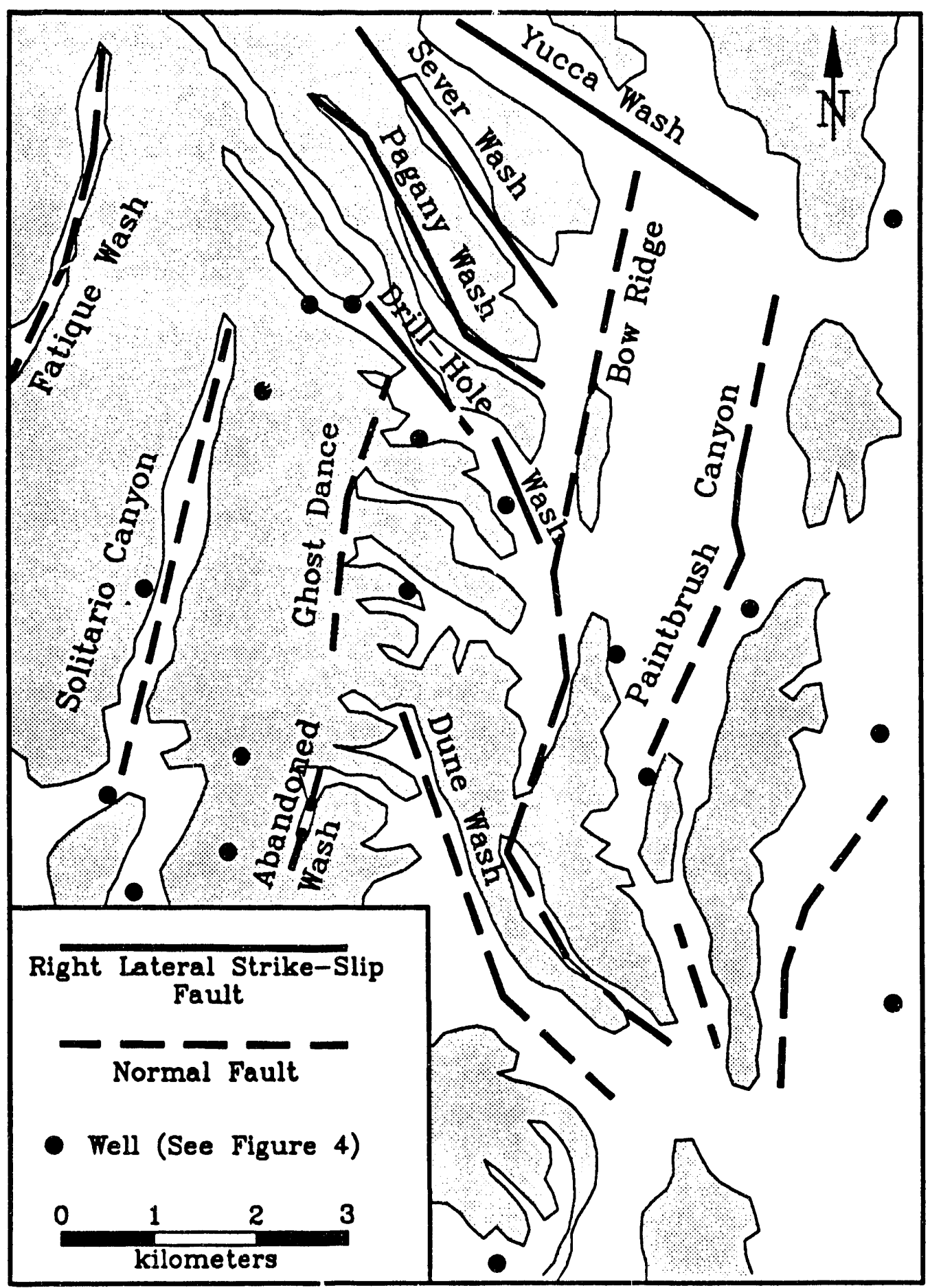

Figure 2: Location of strike-slip and normal faults around Yucca Mountain, Nevada (USGS, 1984). 


\section{Hydrologic Studies}

Yucca Mountain is located in the Great Basin subprovince of the Basin and Range physiographic province. Our current understanding of the spatial and temporary characteristics of recharge in this region is limited. It appears that the major recharge sources to ground water are long duration winter storms, with minor input from summer thundershowers. A generalized ground-water system in the Great Basin is conceptualized as a local flow system consisting of precipitation recharge on the mountain flanks that moves downward through bedrock into valley fill in the basin, where it is discharged through evapotranspiration (Schoff and Moore, 1964). The local system of mountain recharge valley discharge may be underlain by a larger, more regional ground-water basin consisting of several interconnected local systems, which may or may not coincide with the topographic surface watersheds (Naff et al., 1974).

The three prevalent rock types of the study area, valley-fill alluvium, Tertiary volcanic rocks, and Paleozoic carbonate rocks, are geieral aquifer classifications that have been further divided into 12 formal aquifers and aquitards for the NTS area by Winograd and Thordarson (1975) (Table 2). The aquifers with the largest areal distribution are the lower carbonate and the valley-fill aquifers. The tuff aquifers and aquitards are the location of the potential nuclear waste repository horizons at Yucca Mountain.

\section{Lower Carbonate Aquifer}

The lower carbonate aquifer, also known as the regional carbonate aquifer, generally underlies most of the study area and transmits much of the interbasin flow. This aquifer is alternately confined and unconfined (Winograd and Pearson, 1976). Its saturated thickness is a few hundred to a thousand meters and is a function of geology, structure, erosion and elevation of the water table. 


\begin{tabular}{|c|c|c|}
\hline \multicolumn{3}{|c|}{$\begin{array}{c}\text { TABLE } 2 \\
\text { HYDROLOGIC UNITS OF THE NEVADA TEST SITE }\end{array}$} \\
\hline Hydrologic Unit & $\begin{array}{l}\text { Maximum } \\
\text { Thickness } \\
\text { (m) }\end{array}$ & Stratigraphic Unit ${ }^{1}$ \\
\hline Valley Fill Aquifer & 1100 & \\
\hline Lava Flow Aquifer & $\begin{array}{c}75 \\
600 \\
75\end{array}$ & $\begin{array}{l}\text { Basalt of Kiwi Mesa } \\
\text { Rhyolite of Shoshone Mesa } \\
\text { Basalt of Skull Mountain }\end{array}$ \\
\hline Welded Tuff Aquifer & $\begin{array}{l}230 \\
250 \\
375\end{array}$ & $\begin{array}{l}\text { Thirsty Canyon Tuff } \\
\text { Timber Mountain Tuff } \\
\text { Paintbrush Tuff }\end{array}$ \\
\hline Bedded Tuff Aquifer & 300 & Paintbrush Tuff \\
\hline Lava Flow Aquitard & 1200 & Wahmonie Formation \\
\hline Tuff Aquitard & $\begin{array}{l}500 \\
600 \\
150 \\
600\end{array}$ & $\begin{array}{l}\text { Wahmonie Formation } \\
\text { Salyer Formation } \\
\text { Belted Range Tuff } \\
\text { Local Informal Units }\end{array}$ \\
\hline Tuff Aquifer / Aquitard & $\begin{array}{l}600 \\
600\end{array}$ & $\begin{array}{l}\text { Tuff of Calico Hills } \\
\text { Crater Flat Tuff }\end{array}$ \\
\hline Tuff Aquitard & $\begin{array}{c}300 \\
? \\
425 \\
300 \\
?\end{array}$ & $\begin{array}{l}\text { Lithic Ridge Tuff } \\
\text { Older Tuff Units (Unnamed) } \\
\text { Rocks of Pavits Springs } \\
\text { Horse Springs Formation } \\
\text { Granicic Stocks }\end{array}$ \\
\hline Uprer Carbonate Aquifer & 1100 & Tippipah Limestone \\
\hline Upper Clastic Aquitard & 2400 & Eleana Formation \\
\hline Lower Carbonate Aquifer & $\begin{array}{c}425 \\
460 \\
430 \\
90 \\
100 \\
650 \\
615 \\
1400 \\
610\end{array}$ & $\begin{array}{l}\text { Devils Gate Formation } \\
\text { Nevada Formation } \\
\text { undifferentiated } \\
\text { Ely Springs Dolomite } \\
\text { Eureka Quartzite } \\
\text { Pogonip Group } \\
\text { Nopah Formation } \\
\text { Bonanza King } \\
\text { Carrara Formation }\end{array}$ \\
\hline Lower Clastic Aquitard & $\begin{array}{c}70 \\
700 \\
1025 \\
9 ? 5\end{array}$ & $\begin{array}{l}\text { Zabriskie Quartzite } \\
\text { Wood Canyon Formation } \\
\text { Stirling Quartzite } \\
\text { Johnnie Formation }\end{array}$ \\
\hline
\end{tabular}

Modified From Winograd and Thordarson, 1975.

1 See Table 1 For Explanation of Strat:graphic Units 
The stratigraphy of this aquifer is Devonian Devils Gate Formation through the Cambrian Carrara limestones and dolomites. Intercrystalline porosity is low, but secondary permeability is high and water moves primarily along fractures. The greatest fracture density occurs in fine-grained rocks. Often fractures are partially or completely filled with secondary calcite, calcareous clay, or iron oxides (Winograd and Thordarson, 1975).

\section{Volcanic Tuff Aquifers and Aquitards}

The Tertiary volcanic tuffs form a system of interlayered aquifers and aquitards. The tuffs induration ranges from nonwelded to densely welded. Nonwelded tuffs may have interstial porosities as high as 35-40\% (Winograd and Thordarson, 1975), however, secondary mineralization within void spaces decreases permeability; therefore, it has been suggested that the amount of secondary permeability defines whether a tuff unit is either an aquifer or an aquitard. Tuff aquifer transmissivity is a function of degree of fracturing and interconnectiveness of fracture systems. Fracture permeability may be related to the vertical position within a cooling unit, distance from the eruptive source, proximity to faults, secondary mineralization, and lithology (Waddell et al., 1984), and the tectonically controlled stress field. In the tuff aquitards, with less fracture density and/or interconnectiveness, interstitial porosity probably controls ground-water movement (Winograd and Thordarson 1975). The iuff aquitards are the principal hydrologic units in which perched water occurs at the NTS (Winograd and Thordarson, 1975). In the eastern part of the NTS, volcanic rocks commonly transmit water downward to the underlying carbonates; in the western part of the NTS, volcanic rocks act as regional aquifers and move water laterally (Rush, 1970). 


\section{Valley-Fill Aquifer}

This widespread aquifer is composed of Quaternary and Tertiary alluvial fan, lakebed and fluvial deposits, and typically is saturated only beneath the stucturally deepest parts of the intermontane basins and near the discharge areas in the Amargosa Desert (Waddell et al., 1984). Because of the interlayered nature of the fanglomerates and alluvium, horizontal permeability in this unit is generally much greater than vertical permeablility.

\section{Regional Ground-Water Flow Directions}

The regional ground-water flow direction in the lower carbonate aquifer underlying the NTS and vicinity is generally from the north to the southwest, and is thought to eventually discharge into Death Valley, California. Discharge is primarily through evapotranspiration and has been estimated at 25-30 million $\mathrm{m}^{3}$ /year (Miller, 1977). This system is believed to be under steady-state conditions with respect to recharge, storage and discharge for hundreds of years, with some water in transit longer than 10,000 years (Miller, 1977). Smaller local flow systems may be developed within the Tertiary volcanic tuffs, which may or may not be hydrologically connected to the underlying lower carbonate aquifer. Geologic structure and lithology may influence these local ground-water flow directions.

The Death Valley regional ground-water system has been divided into two subbasins, the Ash Meadows subbasin and the Alkali Flat-Furnace Creek Ranch subbasin (Figure 3). Because of the scarcity of data from the lower carbonate aquifer, boundaries of these subbasins are not definite. Figure 3 represents an intermediate location of suggested subbasin boundaries. Yucca Mountain is located within the Alkali Flat-Furnace Creek Ranch subbasin and is probably a 


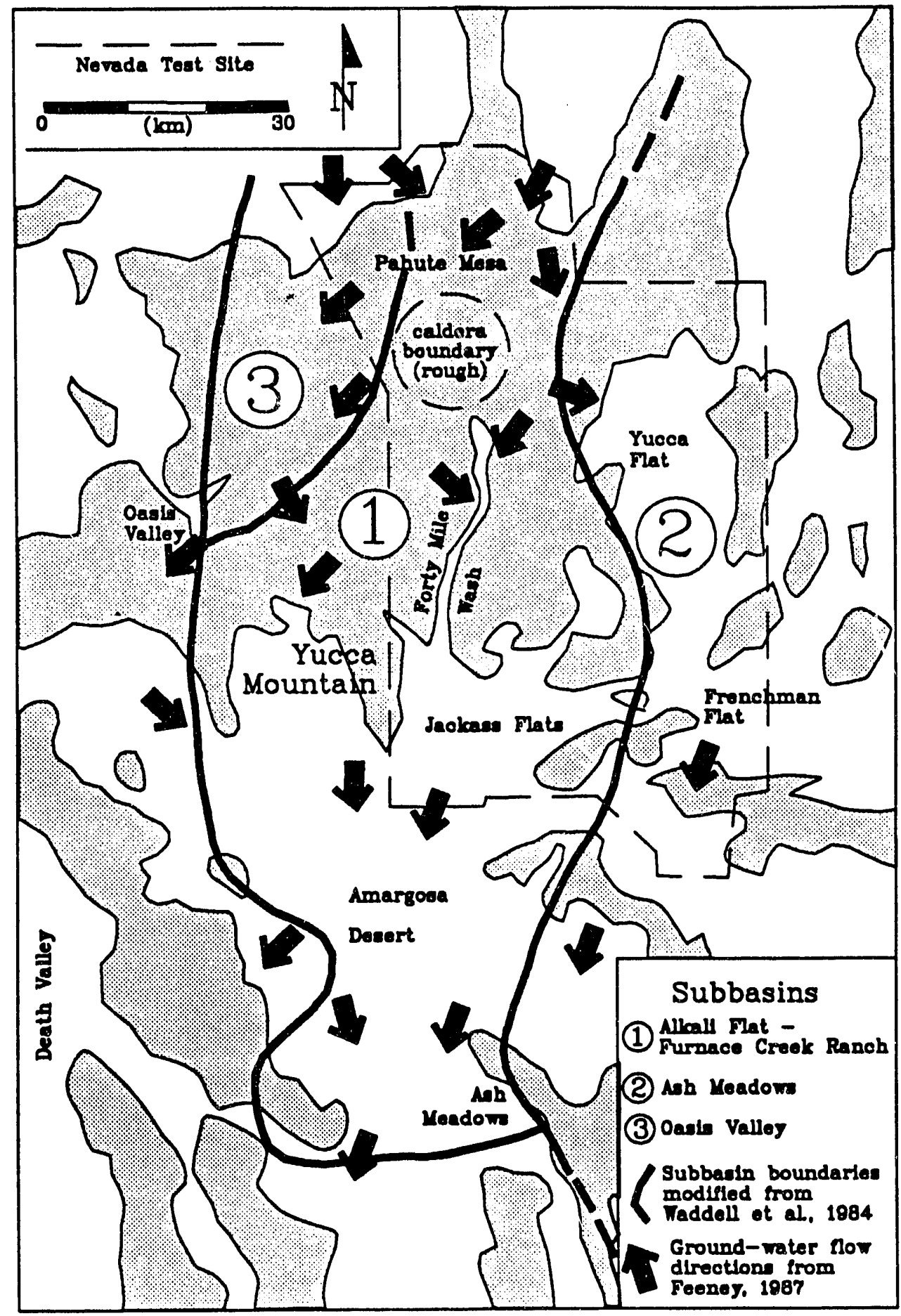

Figure 3: Ground-water flow directions within subbasins of the Death Valley Ground Water Basin in southern Nevada. 
local flow system within the Miocene tufis overlying the regional flow system of the lower carbonate aquifer.

\section{Ash Meadows Subbasin}

The Ash Meadows ground-water basin is located on the eastern side of the NTS (Figure 3). Regional ground-water movement is strongly influenced by the late Mesozoic and early Tertiary deformation of Precambrian and Palezoic miogeosynclinal rocks (Rush, 1970; Naff et al., 1974) and is to the southsouthwest. Semi-perched ground water in Frenchman and Yucca Flats moves from the valley fill to the underlying regional carbonate aquifer (Rush, 1970; Naff et al., 1974; Winograd and Thordarson, 1975; French et al., 1984; Waddell, 1984). This downward flow, has been estimated at $120,000 \mathrm{~m}^{3} /$ year per valley (Rush, 1970). Ground water moves laterally from these valleys to the Amargosa Desert.

The discharge point of this subbasin is an alignment of 15 springs located along a fault-induced barrier in Ash Meadows of the Amargosa Desert where Paleozoic carbonate terrain is juxtapositioned next to Quaternary and Tertiary alluvium. There may be appreciable leakage across this barrier (Rush, 1970). The Ash Meadows ground-water system discharge, temperature and water chemistry have changed little over the past few decades, indicating a steady-state hydraulic condition of a time frame of decades, and possibly since the turn of the century (Winograd and Pearson, 1976).

\section{Alkali Flat - Furnace Creek Ranch Subbasin}

This ground-water subbasin has been alternately described as the Pahute Mesa subbasin (Rush, 1970; French et al., 1984) and the Oasis Valley - Forty Mile Canyon subbasin (Winograd and Thordarson, 1975) (Figure 3). It extends 
from Pahute Mesa in the north to the western one-third of the NTS (including Yucca Mountain), Oasis Valley, and the Amargosa Desert. The actual boundary on the eastern side of this subbasin is still uncertain. Because Tertiary volcanism obliterated most of the carbonate rock directly around Pahute Mesa, the Tertiary volcanic rock aquifer is the principal aquifer, moving water from the recharge areas of Pahute Mesa in the northeast section southward into Oasis Valley, Crater Flat, and western Jackass Flats, then into the Amargosa Desert (Blankennagel and Weir, 1973; Winograd and Thordarson, 1975; Waddell, 1982). Other authors (White, 1979; White and Chuma, 1987) believe that ground water in Forty Mile Wash is from recent recharge and that no underflow from Pahute Mesa occurs.

Ground-water flow direction is generally to the south. Figure 3 indicates flow directions in the Tertiary tuffs, as suggested by Feeney (1987), based upon his Discrete State Compartment (DSC) model using deuterium as a tracer. These flow directions suggest local flow across boundaries, possibly indicating connection between the volcanic flow system and the underlying carbonate system. Feeney's (1987) flow model suggests that the caldera structure in Pahute Mesa may be locally influencing the flow directions.

About one-half of the ground water in Oasis Valley is lost through evapotranspiration, with the rest continuing as underflow to the Amargosa Desert (White, 1979). Some recent isotopic evidence is interpreted by Claassen (1985) to indicate that ground water in the Amargosa Desert was recharged to the valley-fill aquifer primarily by overland flow in stream channels from snowmelt at the end of the Pleistocene, rather than by underflow from the north, and that none of the water is older than 17,000 years B.P.

Waddell (1982), Waddell et al. (1984), and Sinton (1987) suggest that the large Alkali Flat - Furnace Creek Ranch subbasin be further divided into two 
subbasins, with a smaller Oasis Valley subbasin receiving underflow from Pahute Mesa. Waddell (1982) proposes that a flow barrier exists between the southern edge of Pahute Mesa and northern Jackass Flats, perhaps caused by the Timber Mountain Caldera complex, which prohibits underflow from Pahute Mesa to Yucca Mountair.

Discharge from the Amargosa Desert is believed to be through evapotranspiration and underflow to Death Valley (Naff et al., 1974). There is an upward potentiometri head potential in the alluvium in the southern part of Amargosa Desert which may or may not be connected to the underlying carbonates (Waddell et al., 1984).

\section{Ground-Water Flow Around Yucca Mountain}

Some of the sources of the ground water in the tuffaceous aquifer at Yucca Mountain have been sugyested as subsurface flow from other tuffaceous recharge areas, direct recharge from local precipitation or runoff, and upward flow from the regional carbonate aquifer (Kerrisk, 1987). The direction and pathways of ground-water flow surrounding Yucca Mountain are of great interest in characterizing the area for the proposed nuclear waste repository. The regional ground-water flow direction in the underlying lower carbonate aquifer is to the south-southwest, as part of the Alkali Flat-Furnace Creek Ranch ground-water subbasin (Waddell et al., 1984). The direction of vertical ground-water flow between the Tertiary volcanic tuff aquifers and the underlying lower carbonate aquifer at Yucca Mountain could directly affect the travel time of radionuclides to the accessible environment

Yucca Mountain is in an arid region and recharge is considered to be fairly low. Waddell et al., (1984) propose two hypotheses of recharge to Yucca 
Mountain. One is that runoff recharges the alluvium in the washes; however, evapotranspiration may remove this water before it reaches the water table. Another hypothesis suggests that open fractures in surficial bedrock transmit water very quickly below the depth of evaporation. This water then passes through the unsaturated zone to recharge the ground water. Waddell et al., (1984) suggest that recharge will occur as pulses rather than as a steady condition over long periods of time.

Due to the interbedded and fractured nature of the welded and ash-fall tuffs of Yucca Mountain, hydraulic conductivity could be highly anisotropic. Highly fractured welded tuff units might allow for either isotropic or anisotropic flow conditions; in the bedded, nonwelded ash-fall tuffs, vertical conductivity is likely to be smaller than horizontal conductivity. Major fault or fracture zones locally may penetrate both types of lithologies to establish zones of greater vertical hydraulic conductivities. These probable conditions create uncertainty in location and importance of vertical ground-water flow in the Yucca Mountain region.

Temperature measurements in wells USW $\mathrm{H}-1$, USW $\mathrm{H}-4, \mathrm{UE}-25 \mathrm{~b}^{*} 1$ and USW G-2 indicate downward flow in the upper part of the saturated zone, while also indicating a very low upward gradient in the deepest parts of the wells (Waddell et al., 1984). Hydraulic head potentials also increase with depth in wells USW $\mathrm{H}-1$ and UE-25 p"1. Based upon potentiometric head data in wells surrounding Yucca Mountain, the hydraulic head gradient is apparently very low in the volcanics on the eastern side of Yucca Mountain, and much steeper in the volcanic rocks in the northern part of Yucca Mountain (Robison, 1985). Waddell et al. (1984) consider Yucca Mountain to be located within the transitional zone of the regional ground-water flow; therefore, it is considered neither a significant recharge nor discharge area. They suggested that vertical flow, as related to the regional ground-water system, may be in either direction 
(Waddell et al., 1984, p. 61).

Sinton (1987) numerically modeled the ground-water flow in the region of Yucca Mountain by dividing the area into a two-layer model. The upper layer is composed of volcanic and alluvium aquifers and aquitards, and the lower layer represents the lower carbonate aquifer. The amount of vertical leakage is controlled by recharge and discharge, and the difference between the upper and lower layer transmissivities. From this model, Sinton (1987) proposed an upward flux of $44 \mathrm{~m}^{3} /$ year for the Yucca Mountain repository area, and also proposed upward fluxes in Crater Flat, Amargosa Desert, Ash Meadows and Oasis Valley. In contrast, there were downward fluxes in Forty Mile Wash, Pahute Mesa and Timber Mountain.

\section{Ground-Water Chemistry}

\section{Ground-Water Chemistry of the Study Area}

Schoff and Moore (1964) studied the ground-water chemistry at the NTS and came up with three divisions of ground water: a $(\mathrm{Na}+\mathrm{K}) \mathrm{HCO}_{3}$ type found in the volcanic tuffs and tuffaceous valley-fill alluvium; a $(\mathrm{Ca}+\mathrm{Mg}) \mathrm{HCO}_{3}$ type found in the Paleozoic carbonate aquifers and carbonate detritus; and a mixed type from the interaction of ground water traveling between these two. Water from the regional carbonate aquifer, the $(\mathrm{Ca}+\mathrm{Mg}) \mathrm{HCO}_{3}$ type, is found to be relatively uniform in terms of total dissolved solids (TDS) to depths of several thousand meters (Winograd and Thordarson, 1975).

Pahute Mesa, which has been suggested as a source area for Yucca Mountain ground water, has a similar volcanic terrain and diagenetic minerals. The ground water of Pahute Mesa is a sodium-bicarbonate type, with $\mathrm{Na}^{+}+\mathrm{K}^{+}$ comprising $90 \%$ cations (Blankennagel and Weir, 1973). Pahute Mesa may be 
divided hydrologically into two regimes: a nonzeolitized eastern section with decreasing head potential with depth, and a zeolitized western section with increasing head potential with depth. The ground water in the eastern section is primarily a $\mathrm{NaHCO}_{3}$ type, with accessory $\mathrm{Ca}^{2+}$ and $\mathrm{SO}_{4}^{2-}$ (Blankennagel and Weir, 1973). In the western section, sodium, sulfate and chloride contents increase, while calcium decreases, relative to the eastern section (Blankennagel and Weir, 1973). This may be due to longer flow paths in the western section which allow more water/rock interaction and hydrothermal alteration of older volcanic rocks. Secondary mineralization is believed to have formed under closed conditions (Moncure et al., 1981).

Oasis Valley, to the west of the NTS, might be viewed as a small-scale analog of the regional ground-water flow system containing Yucca Mountain, with underflow and recent recharge in Tertiary volcanics and carbonate aquifers. The ground water in Oasis Valley was characterized as $\mathrm{NaHCO}_{3}$ type by Malmberg and Eakin (1962) and $(\mathrm{Na}+\mathrm{K}) \mathrm{HCO}_{3}$ by Winograd and Thordarson (1975). Along a flow path down the valley, modeled as a system open to atmospheric $\mathrm{CO}_{2}$, White $(1979, \mathrm{p} .17)$ found that evapotranspiration causes TDS increases, calcium increases due to $\mathrm{CaCO}_{3}$ input from carbonate rocks of Bare Mountain, and potassium and fluoride are removed by clay minerals and fluorite, respectively. White (1979) also found that in water containing moderate amounts of $\mathrm{Mg}^{2+}$, the principal alteration product is montmorillonite, while if $\mathrm{Mg}^{2+}$ is deficient, but $\mathrm{Na}^{+}$and $\mathrm{K}^{+}$were present, zeolites such as clinoptilolite, mordenite, analcime and chabasite would form. Using environmental isotopes, White and Chuma (1987) suggested underflow from Pahute Meas as a recharge source, and that local recharge occurs in Bullfrog Hills. There is a $5 \%$ deuterium depletion in older ground water. White and Chuma (1987) modeled the ground water in 
Oasis Valley as an open system, a decision based upon the shallow depth $(<10$ m) to ground water. They supported this by noting that $\mathrm{P}_{\mathrm{CO}_{2}}$ and $\delta^{13} \mathrm{C}$ increases and $\delta^{14} \mathrm{C}$ decreases along a flow path. Calcium carbonate saturation is maintained by the dissolution of caliche.

Southern Amargosa Desert is suggested as a possible discharge area for the ground water from Yucca Mountain. Winograd and Thordarson (1975) described the ground water as a mixed type which graded into a $(\mathrm{Na}+\mathrm{K}) \mathrm{HCO}_{3} /$ mixed type to the west. Claassen (1985) divides the water chemistry into three groups: volcanic, carbonate and mixed ground waters, similar to Schoff and Moore's 1964 work on the NTS, that are controlled by the alluvium lithology. Claassen (1985) found that the north-central part of Amargosa Desert has the lowest values of $\mathrm{Na}^{+}, \mathrm{Ca}^{2+}, \mathrm{HCO}_{3}^{-}$and $\mathrm{SO}_{4}^{2-}$, with ion concentrations increasing sharply to the east and west. This coincides with the presence of highly permeable sands and gravels within the center of the Amargosa Desert. Claassen (1985) suggests that, with respect to cation composition, Amargosa Desert ground water is more similar to the NTS spring water compositions derived from perched systems, rather than the regional ground-water table. Amargosa Desert has been modeled as a system that is closed to atmospheric $\mathrm{CO}_{2}$ (Claassen, 1985; White and Chuma, 1987) because $\mathrm{P}_{\mathrm{CO}_{2}}$ decreases along the flow path. Assuming cooler recharge conditions during Pleistocene time, Claassen (1985) used $\delta^{13} \mathrm{C}, \delta \mathrm{D}$ and $\delta^{18} \mathrm{O}$ to support his hypothesis that water was recharged to the valley fill primarily through runoff infiltration and overland flow from Pleistocene snowmelt.

Ground water near Forty Mile Wash, which is located to the east of Yucca Mountain (Figure 4), is thought to be either a mixture of underflow from Yucca 


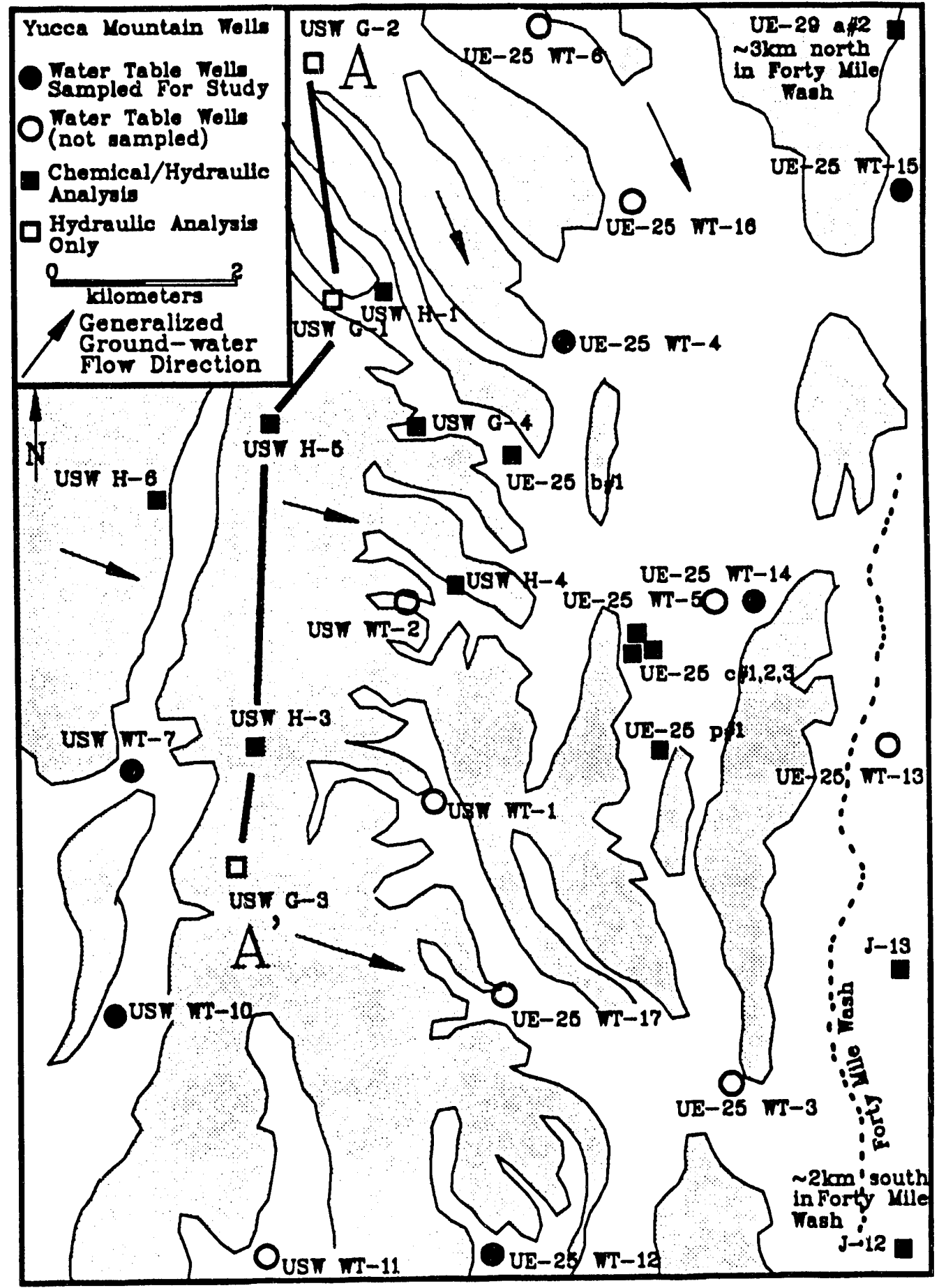

Figure 4: Location of wells with chemical and hydraulic analyses on Yucca Mountain, Nevada. Cross-section $\mathbf{A}-\mathbf{A}^{\prime}$ is Figure 7. 
Mountain and recent recharge (Waddell et al., 1984; White and Chuma, 1987), or derived purely from recent recharge (Claassen, 1985). Three wells are completed in the Tertiary volcanics underlying Forty Mile Wash. Well UE-29 a ${ }^{\#}$, located the farthest upgradient, has a lower ion concentration (except for $\mathrm{Cl}^{-}$) and is isotopically lighter than Yucca Mountain wells (Benson et al., 1983). Wells J-12 and J-13 are higher in ions (except for $\mathrm{Na}^{+}$) and isotopically lighter than Yucca Mountain wells (Benson et al., 1983). Based upon carbon-14 data, uncorrected ground-water ages of these wells are 4,000, 9,100 and 9,900 years B.P. for UE-29 $\mathrm{a}^{\# 2} 2, \mathrm{~J}-12$ and J-13, respectively (Benson and Mickinley, 1985). Ogard and Kerrisk (1984) consider well J-13 to be typical of wells surrounding Yucca Mountain, although this well is used for water supply and as such has undergone extensive pumping, thus likely disturbing the local flow field. White (1981) and White and Chuma (1987) have modeled Forty Mile Wash as a closed system, after a total carbon balance showed decreases of $\mathrm{P}_{\mathrm{CO}_{2}}$ and increases of $\delta^{13} \mathrm{C}$ downgradient. An increase in $\mathrm{CO}_{3}^{2-}$ could result from increased $\mathrm{CaCO}_{3}$ saturation from the dissolution of calcite (perhaps caliche?) by ground water.

\section{Yucca Mountain Ground-Water Chemistry}

Composite ground-water samples have been collected from 20 wells on and surrounding Yucca Mountain (Table 3) which were completed in Tertiary volcanics. The screened interval in each well is generally quite large, up to several hundred meters, thus the sample collected probably represents a mixture of several geologic units and flow paths. Well UE-25 $p^{\# 1} 1$ is sampled from two separate packed intervals in the volcanics and the lower carbonate aquifer in the Paleozoic carbonates. Figure 4 shows the locations of these wells on Yucca Mountain. While no data have been published about the unsaturated zone water, Ogard and Kerrisk (1984) estimated the chemistry of pore water to be in 


\begin{tabular}{|c|c|c|c|c|}
\hline \multicolumn{5}{|c|}{$\begin{array}{c}\text { TABLE } 3 \\
\text { HYDROGEOLOGY OF WELLS SURROUNDING YUCCA MOUNTAIN, NEVADA }\end{array}$} \\
\hline Well & $\begin{array}{c}\text { Depth } \\
(\mathrm{m})\end{array}$ & $\begin{array}{c}\text { Hydraulic } \\
\text { Head } \\
(\mathrm{m})^{1}\end{array}$ & $\begin{array}{l}\text { Sampled } \\
\text { Interval } \\
\text { (m) }\end{array}$ & Producing Unit ${ }^{2}$ \\
\hline $\mathrm{J}-12$ & 347 & 953.2 & $214-264$ & Topopah Spring \\
\hline$J-13$ & 1063 & 727.1 & $207-450$ & Topopah Spring-Tram \\
\hline UE-29 a"2 & 422 & 1188.0 & $\begin{array}{r}87-213 \\
247-354\end{array}$ & Tuff of Calico Hills \\
\hline$U E-25 b^{\# 1}$ & 1220 & 730.3 & $863-875$ & Bullfrog \\
\hline $\mathrm{UE}-25 c^{\# 1}$ & 914 & 728.4 & - & Bullfrog-Tram \\
\hline UE-25 $c^{\# 2}$ & 913 & - & - & Bullfrog \\
\hline$U E-25 c^{\# / 3}$ & 913 & - & - & Bullfrog-Tram \\
\hline UE-25 $p^{\# 1(\mathrm{vol})}$ & 1805 & 729.9 & $381-1197$ & $\begin{array}{l}\text { Tuff of Calico Hills - Crater Flat } \\
\text { Tuff - Lithic Ridge Tuff }\end{array}$ \\
\hline UE-25 p" 1 (carb) & 1805 & 751.0 & $1297-1805$ & $\begin{array}{l}\text { Lone Mountain Dolomite - } \\
\text { Roberts Mountain Formation }\end{array}$ \\
\hline USW G-4 & 915 & 730.1 & $549-915$ & Tram \\
\hline USW $\mathrm{H}-1$ & 1829 & 730.7 & $\begin{array}{l}572-687 \\
687-1829\end{array}$ & Prow Pass \\
\hline USW H-3 & 1220 & 732.4 & $822-1220$ & Tram-Lithic Ridge Tuff \\
\hline USW $\mathrm{H}-4$ & 1220 & 730.7 & $569-1219$ & Bullfrog-Tram \\
\hline USW $\mathrm{H}-5$ & 1220 & 774.7 & - & Bullfrog-Tram \\
\hline USW $\mathrm{H}-6$ & 1220 & 775.6 & $\begin{array}{l}608-646 \\
753-835\end{array}$ & Bullfrog-Tram \\
\hline USW VH-1 & 762 & 779.3 & - & Bullfrog \\
\hline UE-25 WT-4 & 482 & 728.2 & $474-477$ & Tuff of Calico Hills \\
\hline USW WT-7 & 491 & 775.9 & $477-481$ & Topopah Spring \\
\hline USW WT-10 & 430 & 728.0 & $399-403$ & Topopah Spring \\
\hline UE-25 WT-12 & 399 & 729.2 & $382-388$ & Tuff of Calico Hills \\
\hline UE-25 WT-14 & 399 & 729.9 & $393-397$ & Tuff of Calico Hills \\
\hline UE-25 WT-15 & 415 & 728.6 & $403-407$ & Topopah Spring \\
\hline
\end{tabular}

${ }^{1}$ Meters Above Mean Sea Level

2 See Table 1 for Explanation of Stratigraphic Units. 
equilibrium with the rock with which it is in contact. Vadose water in the fractures of the crystalline tuff would likely be higher in $\mathrm{Ca}^{2+}$ and lower in $\mathrm{Na}^{+}$relative to saturated zone water, whereas water in the pores of zeolitized tuff should be similar to saturated zone water because of glass dissolution (Ogard and Kerrisk, 1984). In general, unsaturated zone water should show a higher concentration of ions due to higher evaporation rates than saturated zone water (Kerrisk, 1987).

Kerrisk (1987) cincribed six active processes that may control ground-water chemistry at Yicca Mountain: 1) physical transport of dissolved species with wa.ter; 2) rock-water interactions; 3 ) ion exchange; 4j zas dissolutions; 5) mixing of different water compositions; and 6) evaporation. The last, evaporation, Kerrisk did not consider likely at Yrucca Mountain. The ground water in the tuffs is primarily a $\mathrm{NaHCO}_{3}$ type: $\mathrm{Na}^{+}=65-95 \%$ of cations and $\mathrm{HCO}_{3}^{-}=80 \%$ of anions with subequal $\mathrm{Cl}^{-}$and $\mathrm{SO}_{4}^{2-}$ (Ogard and Kerrisk, 1984).

The ground-water chemistry may be divided into two groups based upon $\mathrm{Ca}^{2+}: \mathrm{Na}^{+}$ratios. The sodic western side of Yucca Mountain, consisting of wells USW $\mathrm{H}-3$, USW $\mathrm{H}-5$ and USW $\mathrm{H}-6$, has higher $\mathrm{Na}^{+}$costent, while the calcic eastern side, wells USW H-1, USW H-4, USW G-4 and UE-25 $\mathrm{b}^{\text {\# }} 1$, has higher relative $\mathrm{Ca}^{2+}$ (Ogard and Kerrisk, 1984; Kerrisk, 1987). Ghost Dance Fault may be an approximate dividing line between the two. Well USW $\mathrm{H}-3$ is considered as the representative well for Yucca Mountain by Ogard and Kerrisk (1984). These wells may be correlated chemically to Pahute Mesa wells UE-19e (sodic) and U-20a2 (calcic) (Ogard and Kerrisk, 1984). Kerrisk (1987) modeled the ground-water chemistry at Yucca Mountain basid upon a system that is open to $\mathrm{P}_{\mathrm{CO}_{2}}$ transfer at the water table surface, and which becomes closed at dept?. Most wells at Yucca Mountain were oxidizing with dissolved oxygen (D.O.) values of $2-6 \mathrm{mg} / \mathrm{l}$; only $\mathrm{UE}-25 \mathrm{~b}^{\#} 1$ and USW $\mathrm{H}-3$ had D.O. values less 
33

than $0.1 \mathrm{mg} / 1$ (Kerrisk, 1987). Ca' sum content is controlled by calcite solubilty, ion exchange and precipitation of smectites. Because of the relatively low $\mathrm{Ca}^{2+}$ concentrations, carbonate above $2 \mathrm{mmole} / \mathrm{l}$ was thought to come from soil zone $\mathrm{CO}_{2}$, rather than from dissolution of carbonate minerals (Kerrisk, 1987).

The ground water from well UE-25 $\mathrm{p}^{* 1} 1$ (carbonate) is the only sample from the Paleozoic carbonate aquifer beneath Yucca Mountain, and thus serves to represent the water chemistry of this aquifer. The amount: of chemical constitents are more concentrated in water from the carbonate aquifers than in the water from the tuffaceous aquifers, with greater $\mathrm{Ca}^{2+}, \mathrm{Mg}^{2+}, \mathrm{Cl}^{-}$and $\mathrm{SO}_{4}^{2-}$ concentrations (Benson and McKinley, 1985). 


\section{METHOD()LOGY}

Geochemical data for this study are from the collection of ground-water samples from six wells surrounding Yucca Mountain and a review of current literature for well and spring data from 17 sources. The data are assembled in a Unix data base (Appendix A), which is a compucer data management system developed by thi Unify Corporation that is useful for storage, organization and retrieval of large amounts of data.

\section{Literature Review}

A literature review on published data on wells and springs in southern Nevada resulted in the collection of information on 135 wells and springs located within the NTS, Amargosa Desert, Oasis Valley and Yucca Mountain. Figure 5 indicates the general location of these data points. The extensive collection of data from areas other than Yucca Mountain was used to 1) compare Yucca Mountain to areas of similar terrain, such as Pahute Mesa, Rainier Mesa and Oasis Valley, which have been extensively studied and modeled; and 2) include recharge (Pahute Mesa) and discharge (Amargosa Desert) areas in the study.

\section{Ground-Water Sampling}

The USGS, as part of the Nevada Nuclear Waste Storage Investigation (NNWSI) study of the water table in the vicinity of Yucca Mountain, completed 16 test wells on the NTS and Bureau of Land Management-administered lands surrounding Yucca Mountain. These 16 wells have been monitored by the USGS 


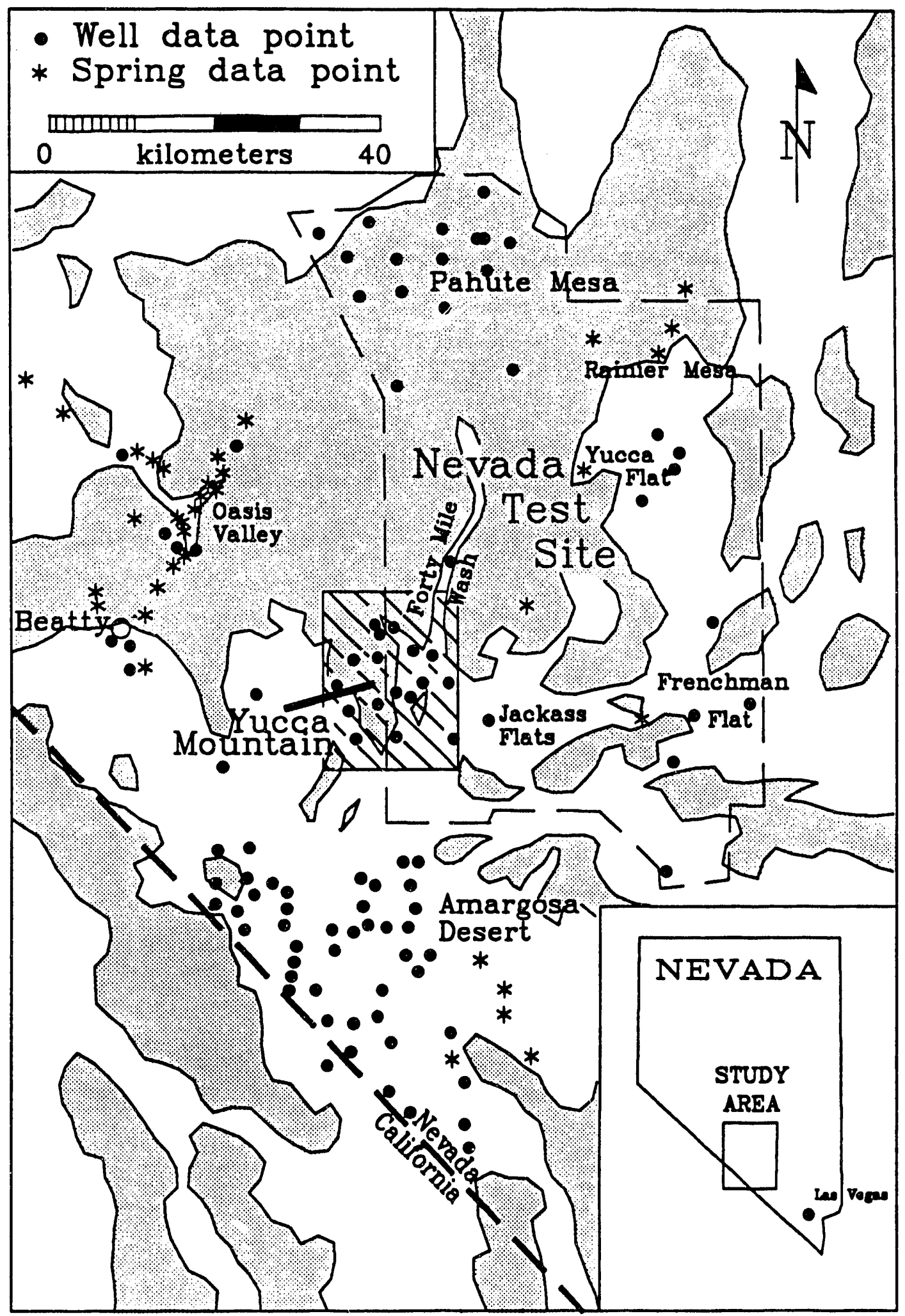

Figure 5: Location of Yucca Mountain and data points in southern Nevada. Hatched box is Figure 2. 
for water-level data; however, the wells were not sampled for ground-water chemistry or isotopic analyses. As part of this current study, samples were collected from six of these wells and analyzed for major and minor element chemistries and isotopic analyses. A complete discussion of the sampling program can be found in Matuska, 1989.

The NNWSI water table (WT) wells are located to the east and south of Yucca Mountain in the surrounding basins. The wells were drilled in 1983 to depths between 348 and 628 meters using conventional rotary methods, with a $\mathrm{LiBr}$ tracer added to the air foam. The boreholes are $22.2 \mathrm{~cm}$ in diameter at depth and have $6.2 \mathrm{~cm}$ steel tubing, which is screened over its last four meters, suspended in the open borehole.

Water-level monitoring transducers, which prevented sample collection, are installed in six of the water table wells, and four other WT wells were deemed unsuitable for sampling because they are either dry or too deep. The WT wells which were sampled are listed in Table 3.

Prior to sampling, a quality assurance sampling program, "Technical Procedure for Ground-Water Sampling and Hydrogeologic Data Aquisition", DTP03.5, was written using sample collection methods suggested by Brown et al. (1970) and Wood (1976), of the USGS. This document contains instructions on collecting ground-water samples, the preparation of the samples for laboratory analysis, as well as field analysis of unstable parameters.

The wells were first logged with the DRI chemical sonde, which consists of an Omega temperature resistance cell and a Yellow Springs Instrument flowthrough fluid conductivity cell that are connected to 1160 meters of four conductor cable. The electronic signal is transmitted to the surface and recorded by a YSI S-C-T meter and Tandy RS-80 portable computer. The initial logging served several purposes: 1) to insure that the well bores were open and free of 
obstructions; 2) to determine water levels; and 3) to record temperature and electrical conductivity profiles of the wells.

After logging, the pump was lowered to within the screened interval and well purging began. The wells were sampled using an air-driven, double-piston pump manufactured by the Robert Bennett Company, which can lift water samples from a depth of $500 \mathrm{~m}$ in a six $\mathrm{cm}$ I.D. well. Samples were collected, within an hour after purging began, from the initial waters for tritium, $\mathrm{LiBr}$ and methylene blue active (MBA) to determine relative amounts of natural purging in the wells since their installation. Purging the wells generally required several days of pumping, during which field parameters such as $\mathrm{pH}$, temperatue, electrical conductivity, alkalinity and flow rate were measured at four- to six-hour intervals.

Once three well volumes had been purged, and the field parameters had stabilized for three successive readings taken 15 to 20 minutes apart, samples for chemical and isotopic analysis were collected. Chemical analysis is performed for major ion chemistry, alkalinity, $\mathrm{SiO}_{2}, \mathrm{MBA}$ and $\mathrm{LiBr}$. Isotopic samples were collected for tritium, deuterium, oxygen-18, carbon-13 and carbon-14 analysis. The chemical and isotopic samples were randomly split with the USGS representative onsite. Quality assurance requirements were met during the sampling procedure by the collection of blanks, duplicates, standards and the required chain-ofcustody.

The WT well data from this sampling program were added to the data base (Appendix A) compiled from the literature review. This data base contains information about the location, static water level, lithology, well depths and producing intervals of the wells, in addition to chemical and isotopic analyses. This data base is the source of the data which is used in the following geochemical modeling and isotope analyses sections. 


\section{CONTROLS ON GEOCHEMISTRY}

\section{Influence Of Volcanic Tuffs}

Extensive flow path geochemical modeling has been conducted on Rainier Mesa, $50 \mathrm{~km}$ northeast of Yucca Mountain, by Claassen and White (1979), White et al. (1980), and Kerrisk (1983). Rainier Mesa is geologically similar to Yucca Mountain. Claassen and White (1979) and White et al. (1980) studied the ground-water flow of Rainier Mesa, using fracture and interstitial water from devitrified, welded crystalline tuffs and nonwelded vitric tuffs, respectively. The glass samples were initially higher in silica and monovalent $\mathrm{Na}^{+}$and $\mathrm{K}^{+}$, while the crystalline rocks were higher in aluminum and bivalent cations $\mathrm{Ca}^{2+}$ and $\mathrm{Mg}^{2+}$ (White et al., 1980). Claassen and White (1979) presented the following model of flow path evolution of a ground water in a volcanic tuff:

1. Aerobic biological activity and recharging water dissolves soil zone atmospheric $\mathrm{CO}_{n}$ in the reaction:

$$
\mathrm{H}_{2} \mathrm{O}+\mathrm{CO}_{2} \rightarrow \mathrm{H}_{2} \mathrm{CO}_{3}
$$

In a simple silicate rock dissolution, all the carbonate species would result from the reaction of this $\mathrm{H}_{2} \mathrm{CO}_{3}$ with the rock.

2. The recharged water leaves the soil zone and reacts with the rock (either vitric or crystalline) in a closed (with respect to atmospheric $\mathrm{CO}_{2}$ ) system. The $\mathrm{H}_{2} \mathrm{CO}_{3}$ contributes $\mathrm{H}^{+}$, which attacks silicate minerals resulting in the release of cations $\left(\mathrm{M}^{+}\right)$and the formation of bicarbonate by the reaction:

$$
\text { (silicate rock) }\left(\mathrm{M}^{+}\right)+\mathrm{H}_{2} \mathrm{CO}_{3} \rightarrow \text { (silicate rock) }\left(\mathrm{H}^{+}\right)+\mathrm{M}^{+}+\mathrm{HCO}_{3}^{-}
$$


As the dissolution proceeds, the aqueous phase becomes saturated and subsequently precipitates zeolites, smectites and feldspar minerals. Differences in fracture and interstitial waters at Rainier Mesa were distinquishable because the fracture water becomes enriched in $\mathrm{Ca}^{2+}$ and $\mathrm{Mg}^{2+}$ and deficient in $\mathrm{K}^{+}$relative to the interstitial waters. White et al. (1980) found that the source of $\mathrm{Ca}^{2+}$ is clinopyroxene, rather than plagioclase feldspar. Interstitial waters, influenced by glass dissolution, are dominated by $\mathrm{Na}^{+}$(White et al., 1980). Both fracture waters and interstitial waters in Rainier Mesa were found to be deficient in $\mathrm{K}^{+}$, which is preferentially retained by glass and minerals. As dissolution proceeds, crystallization of montmorillonite and zeolites provide a sink for the bivalent cations $\mathrm{Ca}^{2+}$ and $\mathrm{Mg}^{2+}$.

Claassen and White (1979) and White et al. (1980) found that incongruent dissolution of the volcanic glass was the primary influence on ground-water chemistry evolution at Rainier Mesa; because of the porous nature of the nonwelded tuff, flow paths and travel times were longer than in the fractures of the crystalline rock, thus allowing more mineral/water interaction.

\section{Minerals Which Influence Chemistry}

Ground-water chemistry in a volcanic rock is controlled by primary glass, pumice fragments and the diagenetic minerals (smectites, zeolites, feldspars) (Claassen and White, 1978). Because of the importance these play in defining ground-water chemistry, a brief discussion about each of these follows. Table 4 gives the mineralogy of diagenetic minerals present at Yucca Mountain.

\section{Volcanic Glass}

Volcanic glass (perlite) is present at Yucca Mountain as part of the finegrained groundmass, as shards and pumice fragments, and as insets in the vitrophyres. Glass is mostly found in the nonwelded horizons above the water table; 


\begin{tabular}{|c|c|c|}
\hline \multicolumn{3}{|c|}{$\begin{array}{c}\text { TABLE } 4 \\
\text { DLAGENETIC MINERALS OF YUCCA MOUNTAIN }\end{array}$} \\
\hline Zeolite & $\begin{array}{l}\text { analcime } \\
\text { clinoptilolite } \\
\text { heulandite } \\
\text { mordenite }\end{array}$ & $\begin{array}{l}\mathrm{Na}\left(\mathrm{Al} \mathrm{Si} \mathrm{S}_{2} \mathrm{O}_{6}\right) \cdot \mathrm{H}_{2} \mathrm{O} \\
\left(\mathrm{Na}_{2}, \mathrm{~K}_{2}, \mathrm{Ca}\right)\left(\mathrm{Al}_{2} \mathrm{Si}_{10} \mathrm{O}_{24}\right) \cdot 8 \mathrm{H}_{2} \mathrm{O} \\
\mathrm{Ca}\left(\mathrm{Al}_{2} \mathrm{Si}_{7} \mathrm{O}_{18}\right) \cdot 6 \mathrm{H}_{2} \mathrm{O} \\
\mathrm{Na} \mathrm{K}\left(\mathrm{Al} \mathrm{Si}_{5} \mathrm{O}_{12}\right) \cdot 3 \mathrm{H}_{2} \mathrm{O}\end{array}$ \\
\hline Feldspar & $\begin{array}{l}\text { albite } \\
\text { adularia }\end{array}$ & $\begin{array}{l}\mathrm{NaAl} \mathrm{Si} \mathrm{O}_{3} \mathrm{O}_{8} \\
\mathrm{KAl} \mathrm{Si}{ }_{3} \mathrm{O}_{8}\end{array}$ \\
\hline Clay & $\begin{array}{l}\text { montmorillonite } \\
\text { illite } \\
\text { chlorite }\end{array}$ & $\begin{array}{l}\left(\mathrm{Na}_{2}, \mathrm{~K}_{2}, \mathrm{Ca}, \mathrm{Mg}\right) \mathrm{Al}_{14} \mathrm{Si}_{2} \mathrm{O}_{60}(\mathrm{OH})_{12} \\
\mathrm{~K}_{0.6} \mathrm{Mg}_{0.25} \mathrm{Al}_{2.3} \mathrm{Si}_{3.5} \mathrm{O}_{10}(\mathrm{OH})_{2} \cdot 4\left(\mathrm{H}_{2} \mathrm{O}\right) \\
\left.(\mathrm{Mg}, \mathrm{Fe})_{3}(\mathrm{Si}, \mathrm{Al})_{4} \mathrm{O}_{10}(\mathrm{OH})_{2}, \mathrm{Fe}\right)_{3}(\mathrm{OH})_{6}\end{array}$ \\
\hline
\end{tabular}

Clay mineral formulas from Hurlbut and Klein, 1977.

Zeolite formulas from Kerrisk, 1983.

however, some glass has been preserved below the water table in dense vitrophryes and lavas (Bish and Vaniman, 1985). The composition of perlite is that of a hydrated high-silica rhyolite with subequal $\mathrm{Na}_{2} \mathrm{O}$ and $\mathrm{K}_{2} \mathrm{O}$, plus $\mathrm{CaO}$ and $\mathrm{H}_{2} \mathrm{O}$ and a silica-to-aluminum ratio of $4.8-5.6$ (Broxton et al., 1986, Broxton et al., 1987). It is the compostion of glass which largely controls the chemistry of the pore water during diagenesis, and hence the secondary mineralization. The most common alteration products of volcanic glass dissolution are cristobalite, which is a metastable, low-temperature polymorph of quartz, and zeolites. The silica concentration in the ground water is thought to be controlled by cristobalite rather than quartz when both phases are present (Bish and Vaniman, 1985).

\section{Zeolites}

Zeolites present at Yucca Mountain are clinoptilolite, heulandite, mordenite and analcime. The zeolites form as replacements of glass in the groundmass of 
the nonwelded tuff, and as fracture fillings in the welded tuff. They are rarely present above the water table, except in zones of perched water or paleowater tables. Zeolites are probably the most common alteration product in the tuffs of Yucca Mountain and in places may constitute more than $90 \%$ of the rock body (Bish et al., 1982; Broxton et al., 1986). There is a lateral and vertical stratification of mineralogy across Yucca Mountain. For example, clinoptilolite is $\mathrm{Ca}^{2+}$-rich at the top of the zeolitized zones, and $\mathrm{Na}^{+}$-rich at greatest depth, while heulandite occurs only locally (Bish, 1984). Lateral zeolite zonation is also present, whereby the zeolites grade from more sodic on the western side of Yucca Mountain to more calcic on the eastern side and potassic in the northern end. Variation of $\mathrm{Ca}^{2+}$ content may have been caused during initial zeolite formation by water from the carbonate aquifer mixing with the tuffaceous water; this does not appear to be occurring at present (Kerrisk, 1987). The abundance of zeolites increases with depth.

\section{Smectites}

Smectites are alteration products of volcanic glasses and feldspars, and are ubiquitous, although in small amounts, throughout Yucca Mountain. Dominant smectites are dioctahedral montmorillonite - beidellites with variable exchangable $\mathrm{Na}^{+}, \mathrm{K}^{+}$and $\mathrm{Ca}^{2+}$. Sodium is the dominant alkaline exchangeable cation in the

shallow smectites, whereas deeper smectites contain subequal $\mathrm{Na}^{+}, \mathrm{K}^{+}$and $\mathrm{Ca}^{2+}$ (Bish, 1988). Interstratified illite/montmorillonite layers become common at depths greater than $1500 \mathrm{~m}$, especially in the northern section of Yucca Mountain (Bish, 1988). Bish (1988) noted that chloritic interlayers are also present in the northern sections. Smectites are the major fracture filling minerals above the water table (Carlos, 1985) and have a tendency to be concentrated along structures such as major strike-slip faults (Bish and Vaniman, 1985). 


\section{Diagenetic Mineral Zones}

Distribution of the diagenetic minerals falls into four zones similar to those proposed by lijama (1980) for zeolite zonation. Broxton et al. (1986) applied this distribution of diagenetic minerals to Yucca Mountain, and from shallowest downward the zones are:

ZONE I : Found above the water table, this zone has substantial amounts of unaltered volcanic glass with minor heulandite and calcic clinoptilolite present locally in fractures, and incipient alteration of glass to smectite and opal in the groundmass. Some calcite is present as fillings in pumice fragments. Clinoptilolite occurs at the base of this zone in the Topopah Spring member of the Paintbrush Tuff.

ZONE II : This zone is vertically discontinuous, generally forming within the nonwelded tops and bases of the Tuff of the Calico Hills through the Crater Flat Tuff formations. Zone II is found both above and below the water table, and is postulated to be the major geologic sorptive barrier to radionuclide transport. Clinoptilolite completely replaces volcanic glass, and makes up $50-75 \%$ of the rock in the upper portions of this zone, whereas mordenite increases in abundance in the lower sections of the zone. Minor cristobalite, feldspar $\left(\mathrm{Or}_{99-100}\right)$ and smectite are present.

ZONE III : This zone is entirely below the water table and occurs as a continuous unit within dacite lavas and flow breccias and the Lithic Ridge Tuff. This zone is discontinuous at the tops and basal layers of members of the Crater Flat Tuff in well J-13. In Zone III, analcime progressively replaces clinoptilolite and mordenite. Some quartz and calcite are present in vugs, and smectites increase in the groundmass.

ZONE IV : This zone occurs in the lower tuff layers of the unnamed older tuff sequence. Most of the hydrologic wells of Yucca Mountain do not 
penetrate to this depth. In this zone, analcime is replaced by authigenic albite. The groundmass consists of cryptocrystalline quartz and feldspar; plagioclase phenocrysts are altered to albite, calcite and illite, and sanidine phenocrysts are either unaltered or altered to orthoclase. Calcite and chlorite minerals are minor, but ubiquitous.

Figures 6 and 7 show the distribution of these zones at Yucca Mountain. Reactions occurring in Zones I and II are hydration processes, while those in Zones III and IV are dehydration processes (Moncure et al., 1981).

Diagenesis is accompanied by widespread mobilization and redistribution of elements, especially the alkaline earths. Therefore, despite very similar starting compositions of the tuffs, this has resulted in a broad division of the diagenetic minerals laterally and vertically. Sodium and potassium are generally depleted in the zeolitized tuff (as compared to the non-zeolitized tuff) and enriched in calcium. The eastern side of Yucca Mountain is considered a calcic-rich suite, and the western side an alkalic-rich suite, with a potassic-rich suite in the northern end (Broxton et al., 1986, and Broxton et al., 1987). 


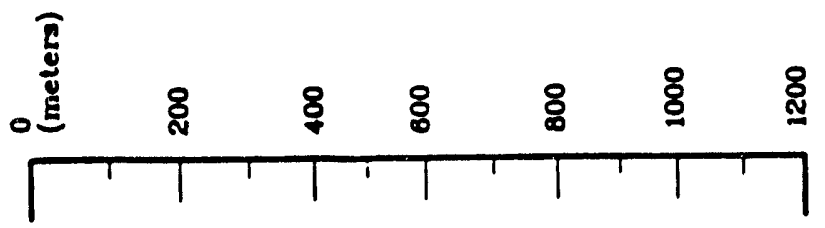
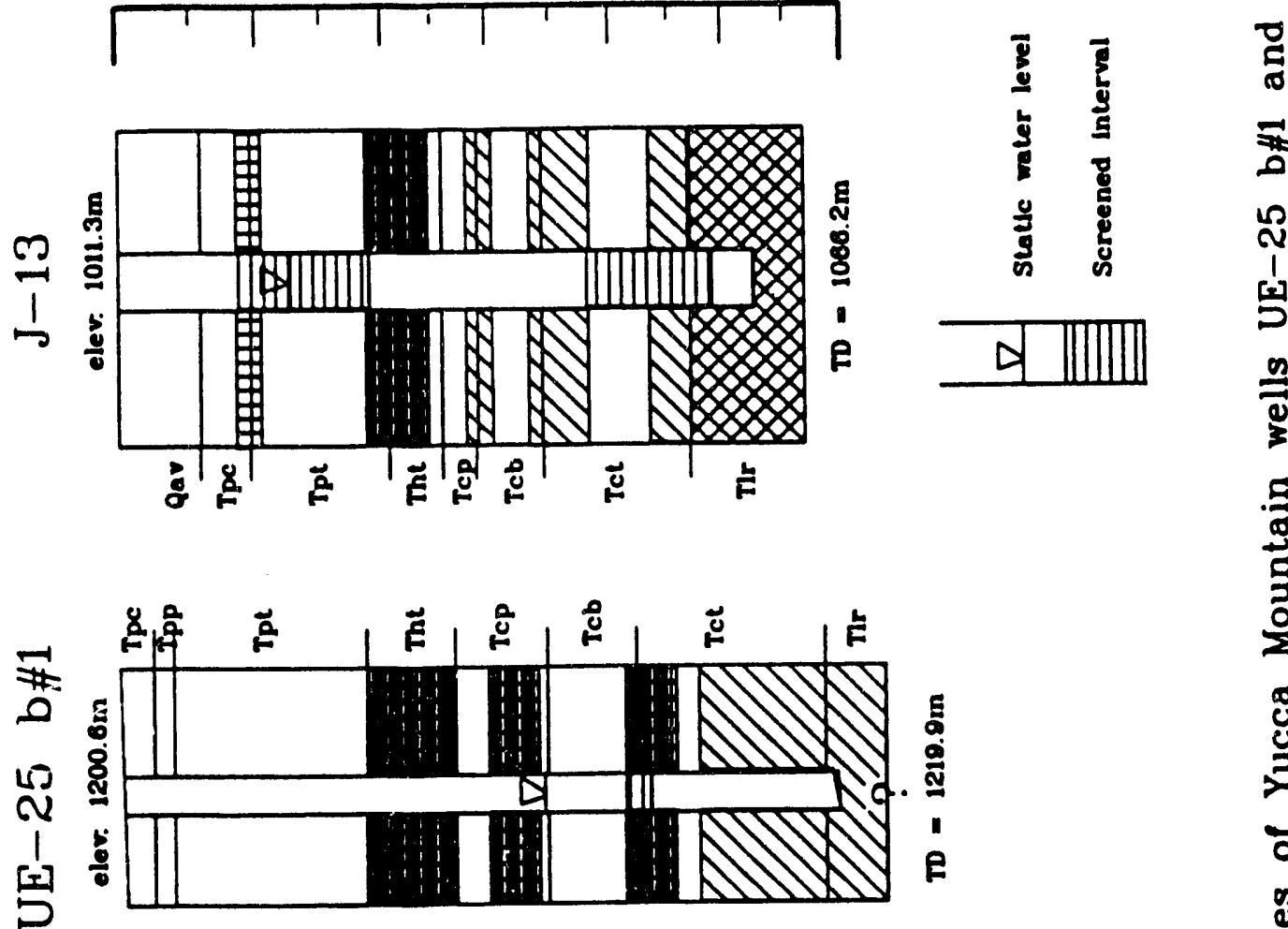

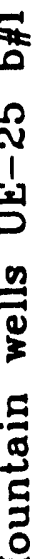

$\sum$

\& 9

림

б.

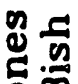

ㅎำ

N

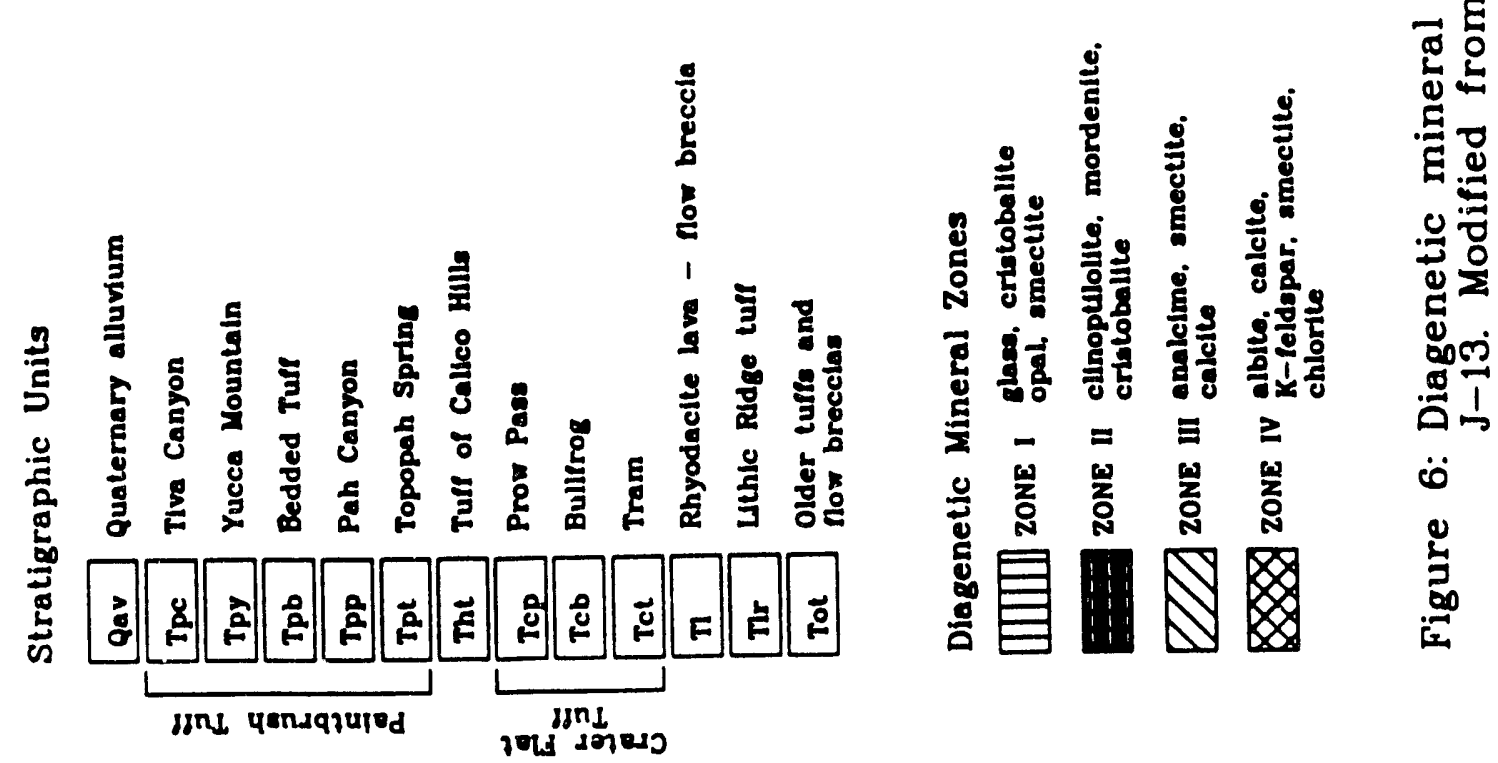




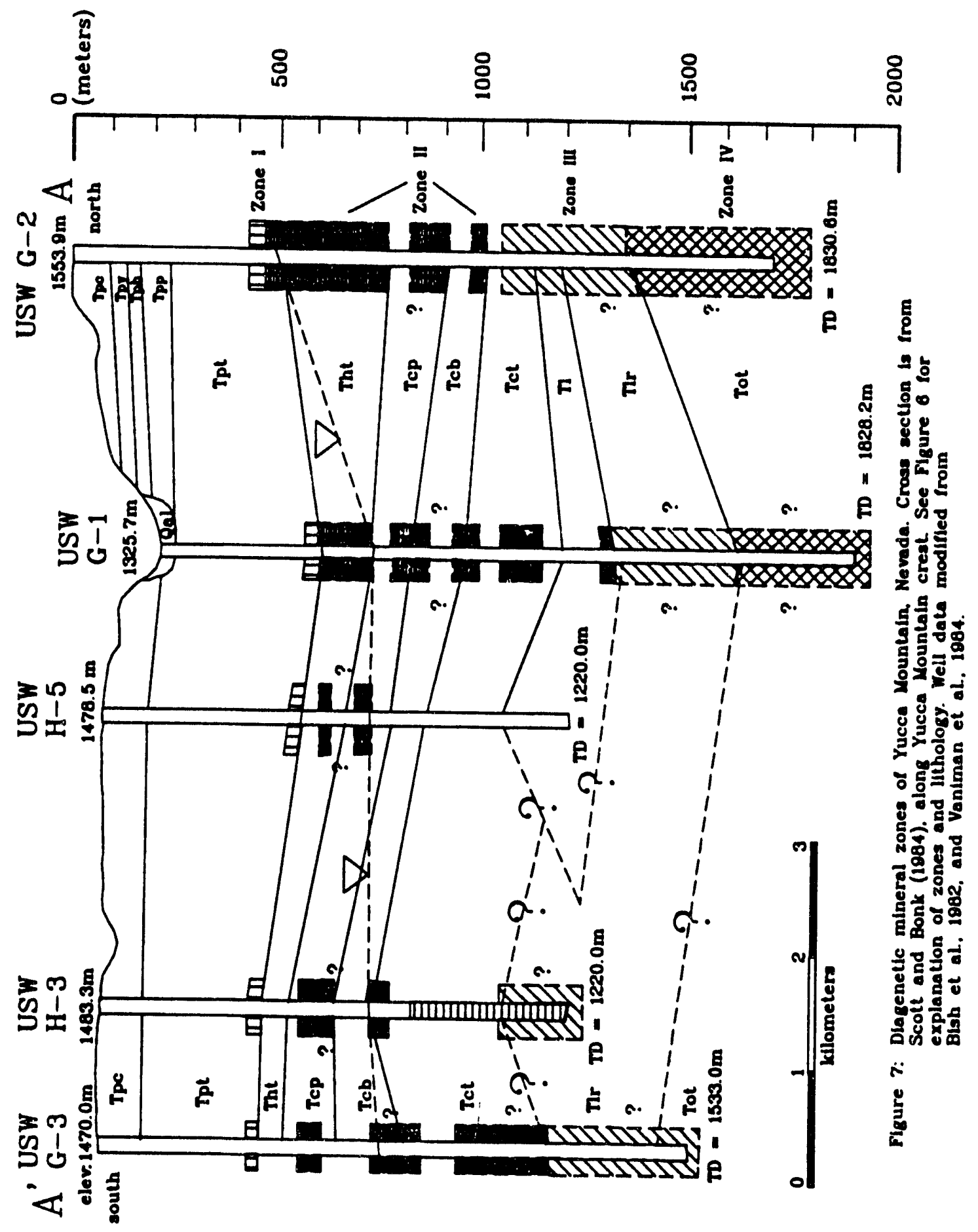




\section{GEOCHEMICAL COMPUTER MODELS}

The objective of this study is to determine if there is evidence of upward ground-water flow from the Paleozoic carbonate aquifer to the volcanic tufis through the use of geochemical models. The approach is to trace a hypothetical flow path and subsequent changes in chemistry of a ground-water solution as it passes through a tuffaceous aquifer. This hypothetical tuffaceous water is then mixed with a water sample from the carbonate aquifer, and the results compared to water samples collected from Yucca Mountain wells. The computer programs used to achieve these goals are BALANCE, NATEQDR and PHREEQE.

BALANCE (Parkhurst it al., 1982) was developed to define and quantify chemical reactions between water and minerals through simultaneously solving a set of linear equations specified by the user. BALANCE is used as a check on the solutions developed aiter modeling the reaction path with PHREEQE. "ihis is accomplished by mass balancing the phases precipitating or dissolving between two water samples and comparing the results to the PHREEQE mass balance. BALANCE is also used as an indicator of mixing amounts (percentages) of two waters to form a ihird.

The DRI uses WATEQDR (Bohm and Jacobson, 1981), which is an updated version of WATEQF (Plummer et al., 197b). WATEQDR, which is short for WATer EQuilibrium (DRI version), thermodynamically models the equilibrium distribution of aqueous species and ions of a given water sample. From this, states of equilibrium of the water with respect to solid phases (minerals) are calculated. These include activity coefficients, ionic activity products, saturation 
indices and partial pressure of gases. WQPLOT, a subprogram of WATFQDR, constructs graphs of these parameters that describe the solution. Because the thermodynamic database of WATEQDR cannot be easily modified to include zeolites and smectites, WATEQDR is used for an initial well-by-well study of water-mineral equilibria at Yucca Mountain prior to modeling the flow path in PHREEQE, and for graphical comparisons of the modeled flow path to the well samples.

PHREEQE (Parkhurst et al., 1980), which is an acronym for pH-RedoxEquilibrium-EQuations, predicts geochemical reactions based on an ion-pairing aqueous model with a thermodynamic data base that can be extensively modifed by the user. This program combines the qualities of both BALANCE and WATEQDR by mass balancing solutions to minerals phases and solvine the solution for various parameters. PHREEQE can be used to simulate a flow path through a tuffaceous aquifer by computing reactions involving the addition of reactants to a solution and mineral suite, and solving for mineral equilibria of the resulting solution. PHREEQE is also used to mix carbonate aquifer water with the modeled tuffaceous water in set ratios and in proportions suggested from BALANCE output. The resultant solutions from the flow path modeling and mixing are compared to the chemistry analyses from Yucca Mountain wells. A listing of the input, thermodynamic data and a semple of the output used to model the flow path and mix the resulting solution with earbonate water using PHREEQE are given in Appendix B. 


\section{WATEQDR ANALYSIS}

An initial analysis of the Yucca Mountain well-water analyses was completed using WATEQDR to solve for equilibrium distribution of the species and mineral phases present. The ground water was found to be supersaturated with respect to montmorillonite, adularia, albite, cristobalite, chalcedony and quartz, and undersaturated with zeolites and calcite.

Mineral stability diagrams were first constructed for minerals likely to be present. The phase boundaries were determined using thermodynamic data from Robie and Waldbaum (1968), Helgeson (1969) and Naumov et al. (1974) (Table 5); these are the sources used in the WATEQDR thermodynamic data base.

The temperature of the Yucca Mountain ground water ranges from $22.7^{\circ} \mathrm{C}$ in well UE-29 a $\mathrm{a}^{\#} 2$ to $56.0^{\circ} \mathrm{C}$ in the carbonate aquifer of well UE-25 $\mathrm{p}^{\#} 1$, (Benson and McKinley, 1985) (Figure 8) and may be roughly divided into two sets of data with averages of $25^{\circ} \mathrm{C}$ and $37^{\circ} \mathrm{C}$, respectively. In general, wells from Forty Mile Wash are lower in water temperature than wells on Yucca Mountain. Wells USW H-3, UE-25 WT-14 and UE-25 WT-15 are exceptions to the higher tempsrature Yucca Mountain wells, and are grouped with the lower temperature wells. Because of the two temperature groups, the mineral stability diagrams were constructed for $25^{\circ} \mathrm{C}$ and $37^{\circ} \mathrm{C}$. The temperature of $32^{\circ} \mathrm{C}$ was chosen as the dividing point. Figure 8 also shows the range of $\log \left[\mathrm{H}_{4} \mathrm{SiO}_{4}\right]$, determined by WATEQDR, to be from $\mathbf{- 3 . 3}$ to $-\mathbf{3 . 0}$. Because of this low range, a value of $\log \left[\mathrm{H}_{4} \mathrm{SiO}_{4}\right]=-3.1$ was chosen for the calculations of the phase boundaries in the mineral stability diagrams. 


\begin{tabular}{|c|c|c|c|c|c|}
\hline \multirow[t]{2}{*}{ THERMODYNAMIC } & $\begin{array}{c}\text { TABLE } 5 \\
\text { DATA USED IN GRC } \\
\text { AT } 25^{\circ} \mathrm{C} \text { and } 1 \mathrm{~B}\end{array}$ & $\begin{array}{l}\text { UND-WAT } \\
\mathrm{R}\end{array}$ & R MODELI & & \multirow[b]{2}{*}{ Source } \\
\hline & Mineral & $\begin{array}{c}\Delta \mathrm{H}_{\mathrm{f}} \\
\mathrm{kcal} / \mathrm{mol}\end{array}$ & $\begin{array}{c}\Delta \mathrm{G}_{\mathrm{f}} \\
\mathrm{kcal} / \mathrm{mol}\end{array}$ & $\begin{array}{c}\Delta \mathrm{S}_{\mathrm{f}} \\
\mathrm{cal} / \cdot \mathrm{K}\end{array}$ & \\
\hline $\mathrm{Al}^{3+}$ & - & -127.00 & -116.00 & - & 1 \\
\hline $\mathrm{Ca}^{2+}$ & - & -129.71 & -132.18 & -13.19 & 1 \\
\hline $\mathrm{K}^{+}$ & - & -60.30 & -67.70 & 24.19 & 1 \\
\hline $\mathrm{Mg}^{2+}$ & - & -110.35 & -108.90 & -28.62 & 1 \\
\hline $\mathrm{Na}^{+}$ & - & -57.43 & -62.54 & 14.10 & 1 \\
\hline $\mathrm{Al}(\mathrm{OH})_{4}^{-}$ & - & -356.19 & -312.00 & 34.49 & 1 \\
\hline $\mathrm{H}_{2} \mathrm{O}$ & - & -68.32 & -56.69 & 16.71 & 1 \\
\hline $\mathrm{H}_{4} \mathrm{SiO}_{4}$ & - & -348.95 & -312.62 & 42.90 & 1 \\
\hline $\mathrm{Al}_{2} \mathrm{Si}_{2} \mathrm{O}_{5}(\mathrm{OH})_{4}$ & kaolinite & -979.46 & -902.86 & 48.53 & 2 \\
\hline $\mathrm{SiO}_{2}$ & chalcedony & -217.28 & -204.28 & 9.87 & 3 \\
\hline $\mathrm{SiO}_{2}$ & cristobalite & -216.93 & -204.07 & 10.37 & 2 \\
\hline $\mathrm{SiO}_{2}$ & quartz & -217.65 & -204.64 & 8.87 & 2 \\
\hline $\mathrm{CaAl}_{2} \mathrm{Si}_{2} \mathrm{O}_{8}$ & anorthite & -1109.30 & -955.63 & 48.45 & 2 \\
\hline $\mathrm{KAlSi}_{3} \mathrm{O}_{8}$ & adularia & -945.00 & -892.60 & 63.43 & 2 \\
\hline $\mathrm{NaAlSi}_{3} \mathrm{O}_{8}$ & albite & -934.51 & -882.69 & 54.66 & 2 \\
\hline $\mathrm{CaAl}_{2} \mathrm{Si}_{7} \mathrm{O}_{18} \cdot \mathrm{H}_{2} \mathrm{O}$ & heulandite & -2527.50 & -2331.43 & - & 3 \\
\hline $\mathrm{NaAlSi}_{2} \mathrm{O}_{0} \cdot \mathrm{H}_{2} \mathrm{O}$ & analcime & -786.34 & -734.26 & 56.03 & 2 \\
\hline $\mathrm{Ca}_{0.107} \mathrm{Al}_{2.33} \mathrm{Si}_{3.67} \mathrm{O}_{10}(\mathrm{OH})_{2}$ & Ca-montmorillonite & -1367.98 & -1279.24 & 61.21 & 4 \\
\hline $\mathrm{K}_{0.33} \mathrm{Ad}_{2.33} \mathrm{Si}_{3.07} \mathrm{O}_{10}(\mathrm{OH})_{2}$ & K-montmorillonite & -1369.60 & -1280.20 & 63.41 & 4 \\
\hline $\mathrm{Na}_{0.33} \mathrm{Al}_{2.33} \mathrm{Si}_{3.07} \mathrm{O}_{10}(\mathrm{OH})_{2}$ & Na-montmorillonite & -1366.83 & -1277.75 & 62.81 & 4 \\
\hline $\mathrm{K}_{0.0} \mathrm{Mg}_{0.25} \mathrm{Ad}_{2.3} \mathrm{Si}_{3.5} \mathrm{O}_{10}(\mathrm{OH})_{2} \cdot 4\left(\mathrm{H}_{2} \mathrm{O}\right)$ & illite & -1391.46 & -1300.98 & 66.44 & 4 \\
\hline$\left.(\mathrm{Mg}, \mathrm{Fe})_{3}(\mathrm{Si}, \mathrm{Al})_{4} \mathrm{O}_{10}\right)_{2}(\mathrm{Mg}, \mathrm{Fe})_{3}(\mathrm{OH})_{6}$ & chlorite & -2127.53 & -1973.54 & 115.44 & 5 \\
\hline
\end{tabular}

Sources: 1) Naumov et al., 1974

2) Robie and Waldbaum, 1968.

3) Helgeson et al., 1978.

4) Helgeson, 1969.

5) Karpov et al., 1971. 


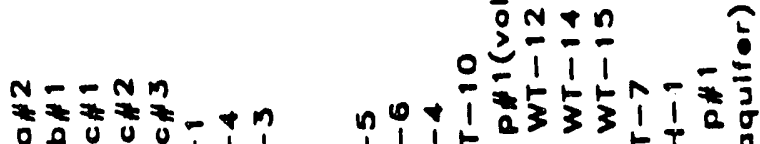

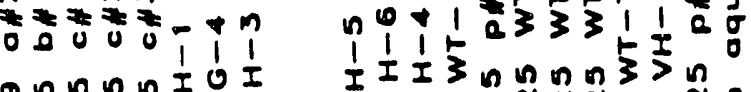

กำกำ

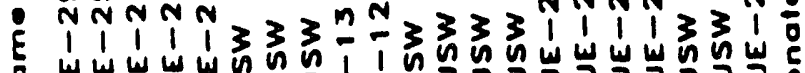

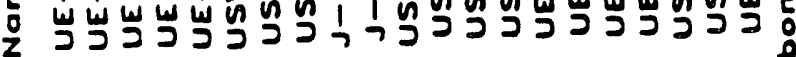

= || || || || || || || || || || || || || ||

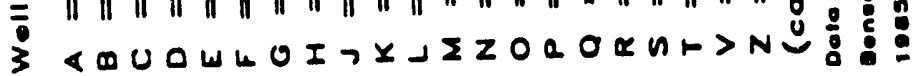

Z

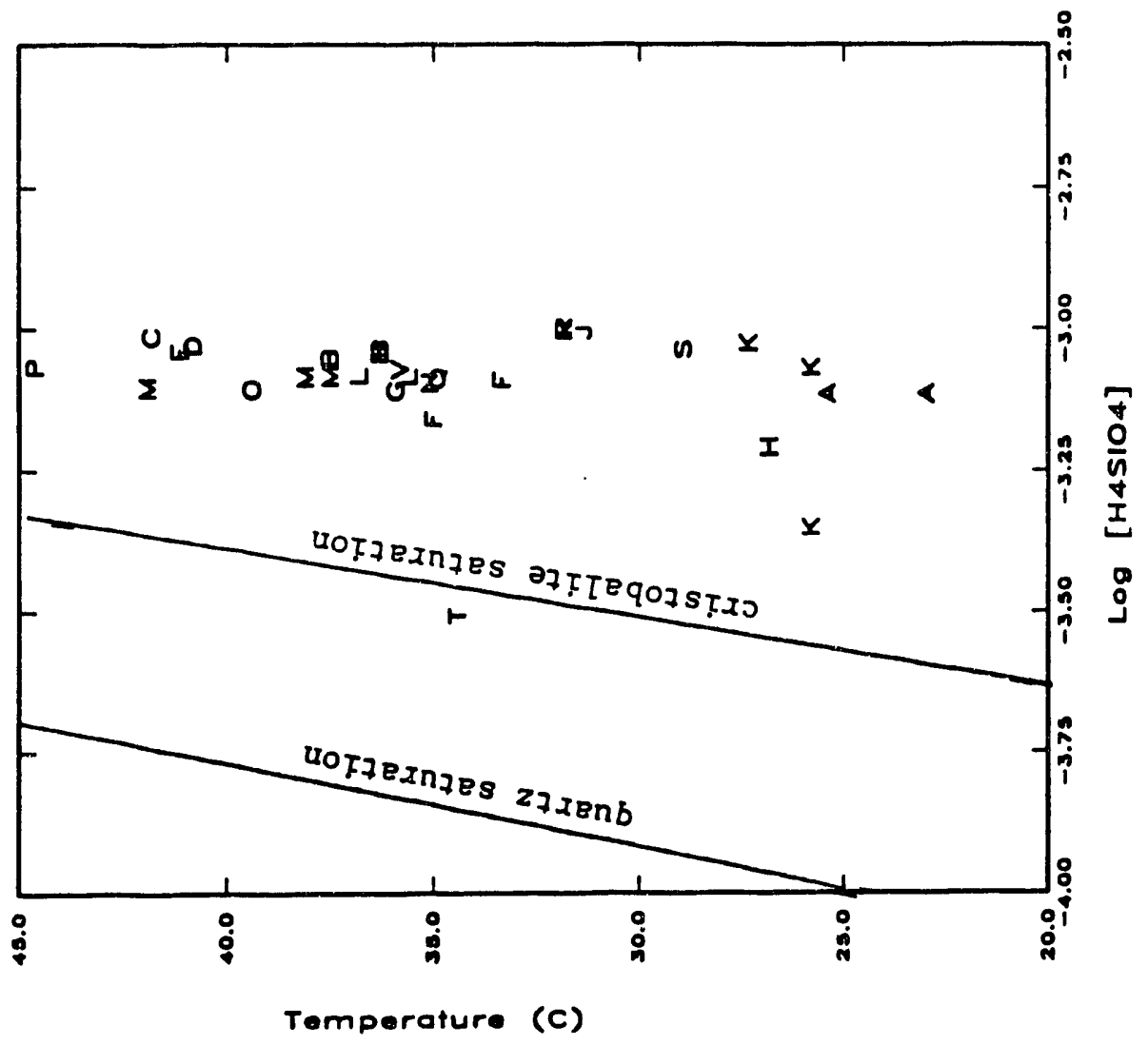

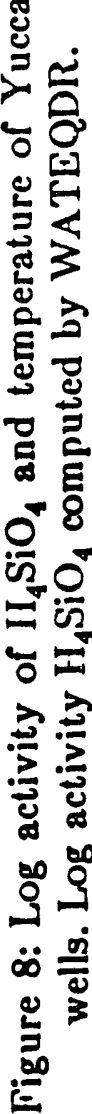


Figures 8 and 10 show the changes in mineral stability boundaries for the $\mathrm{Na}_{2} \mathrm{O}-\mathrm{K}_{2} \mathrm{O}-\mathrm{Al}_{2} \mathrm{O}_{3}-\mathrm{SiO}_{2}$ and $\mathrm{CaO}-\mathrm{Na}_{2} \mathrm{O}-\mathrm{Al}_{2} \mathrm{O}_{3}-\mathrm{SiO}_{2}$ systems, respectively, at 1 bar pressure and $25^{\circ} \mathrm{C}$ and $37^{\circ} \mathrm{C}$. As the temperature increases, the stability fields of kaolinite and adularia increase, and that of $\mathrm{K}$-montmorillonite decreases. There are only slight changes to the stability boundaries of Namontmorillonite, Ca-montmorillonite and albite with the increase in temperature.

Mineral equilibria of the study area, except for Yucca Mountain, are plotted in Figures 11 and 12. Figure 11 shows the stability fields of $\mathrm{Na}-\mathrm{K}$ minerals for the entire study area. At $25^{\circ} \mathrm{C}$, data lie within smectite and feldspar stability fields. Pahute Mesa (P) data (Blankennagel and Weir, 1973) have the highest $\mathrm{Na}^{+} / \mathrm{K}^{+} \log$ activity ratios and thus generally plot within the $\mathrm{Na}$ montmorillonite phase. Data from Amargosa Desert (A) (Claassen, 1985) are more $\mathrm{K}^{+}$enriched and lie within the $\mathrm{K}$-montmorillonite and adularia fields. Oasis Valley (O) data (Malmberg and Eakin, 1962; White, 1979) lie between the two, are subequal in $\mathrm{Na}^{+}$and $\mathrm{K}^{+}$clays, and, assuming that the adularia field represents a more evolved flow path than do the smectite fields, are slightly more evolved along the flow path than their Pahute Mesa source.

At $37^{\circ} \mathrm{C}$, the data are stable only within the adularia mineral field. This suggests that the water samples with warmer temperatures are more evolved along the flow path than those with lower temperatures. If a flow path from Pahute Mesa to Oasis Valley to the Amargosa Desert is traced, as proposed by Winograd and Thordarson (1975), it appears that the $\mathrm{K}^{+}$to $\mathrm{Na}^{+} \log$ activity ratio increases along the flow path.

Mineral stability relationships of the $\mathrm{Ca}-\mathrm{Na}$ diagenetic minerals (Figure 12) show that all the data plot within the Ca-montmorillonite field at both $25^{\circ} \mathrm{C}$ and $37^{\circ} \mathrm{C}$. Again following a Pahute Mesa to Amargosa Desert flow path, a 

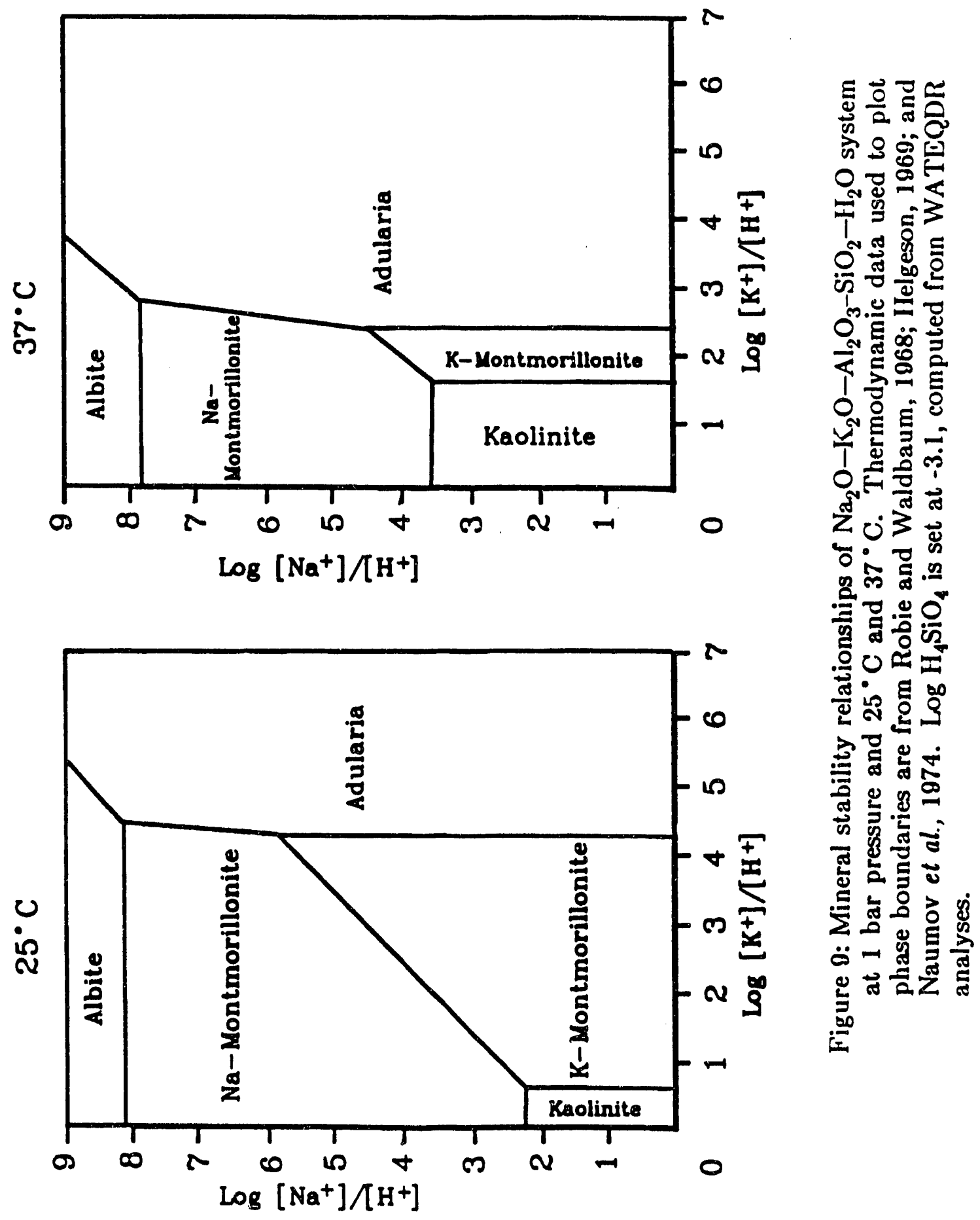

훱흠 훙

요용

워워

T政

○。

is 은

m. ․ㅡㄹ

O

र

중형

ज

Tे

元

Z゙ं

ธำ

放

뭉

ब。结

ర人

농

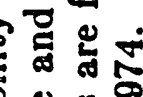

这

密哥

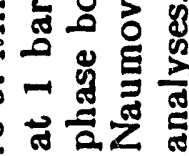



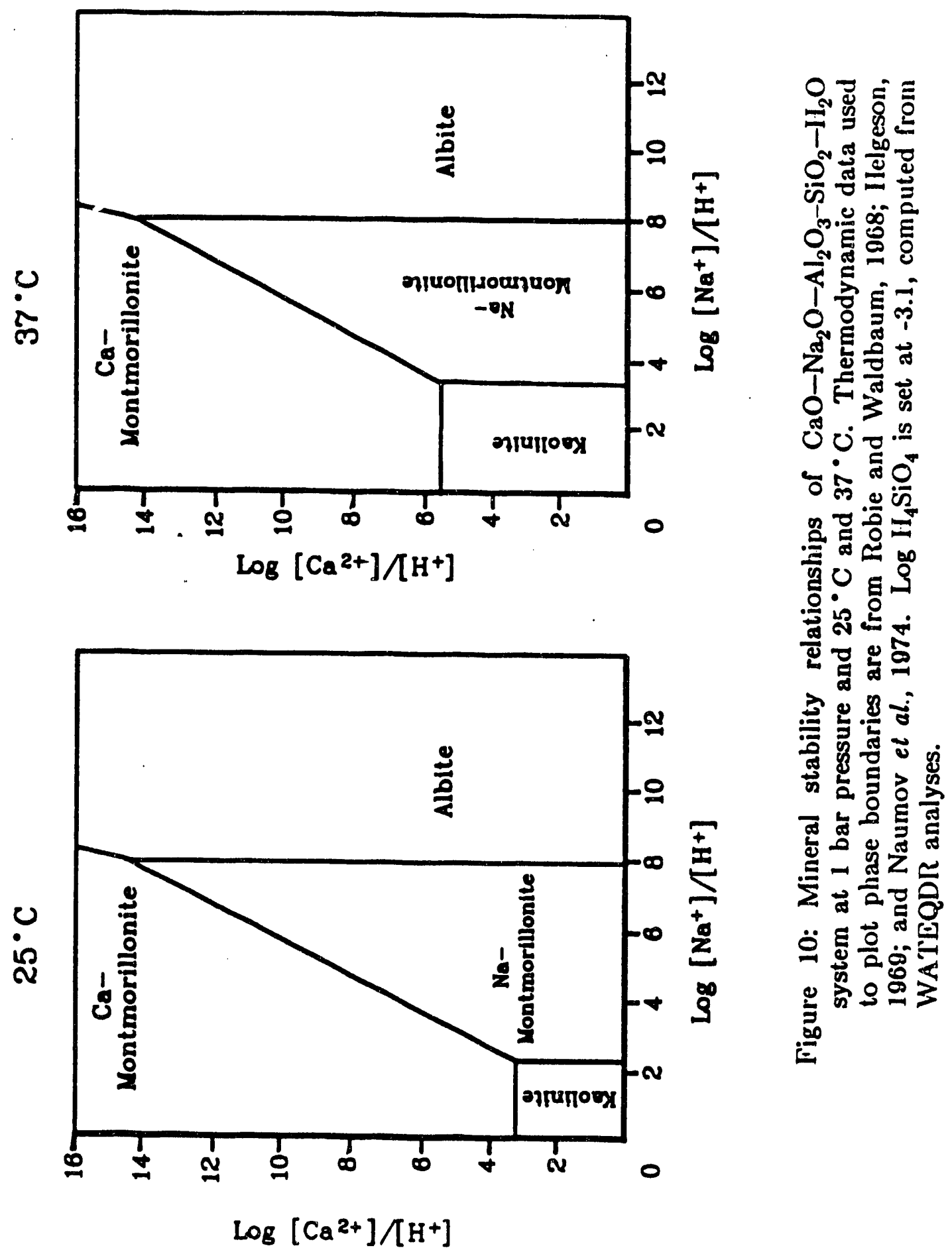

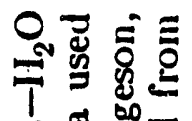
ก 的 on 胞 。 दे हे ㅇํㄹ 乙ौ

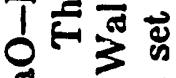
ชే 0 ชั 을 ज正 ชิ 웅 눙 굼 ذิ 等 E ค。

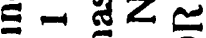
的可 형은 3 $=$ 


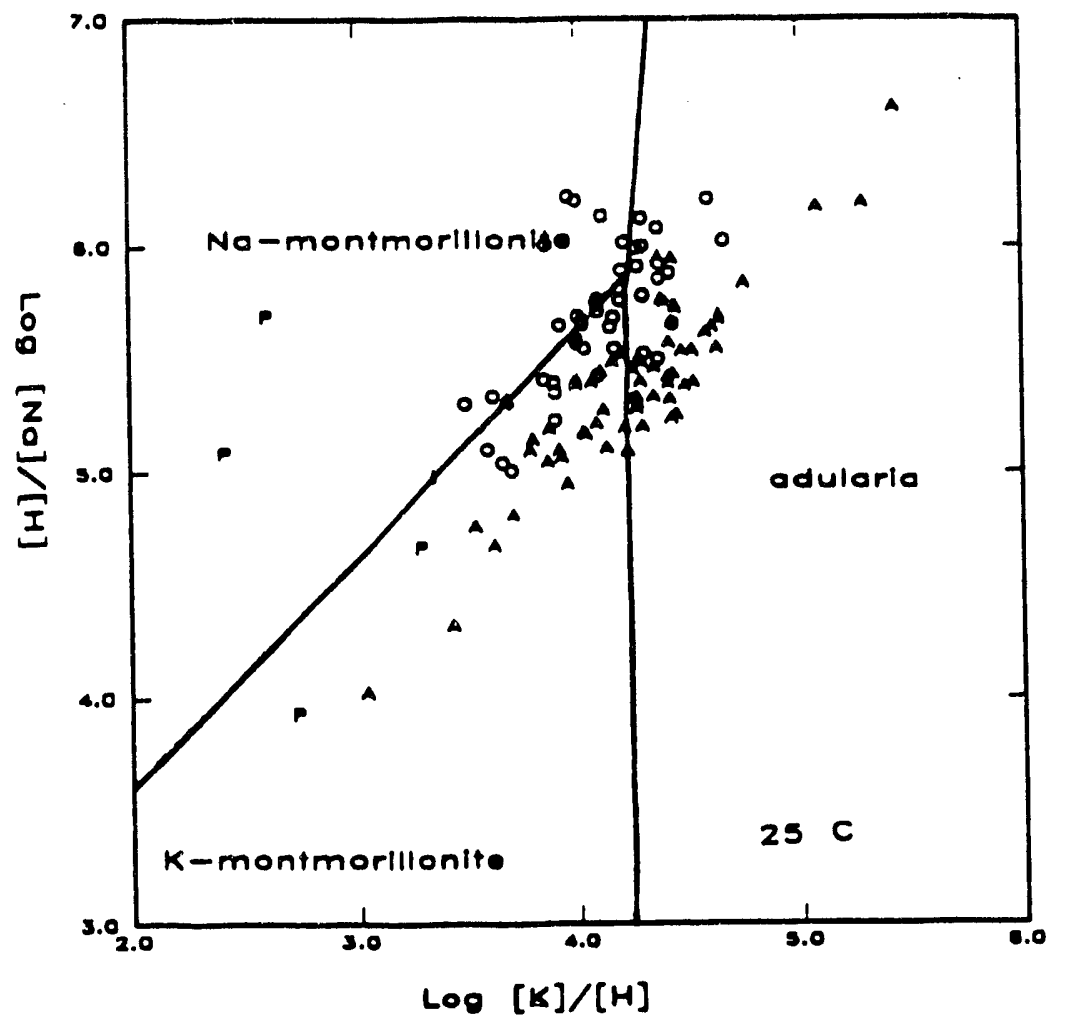

Location
$A=$ Amorooso

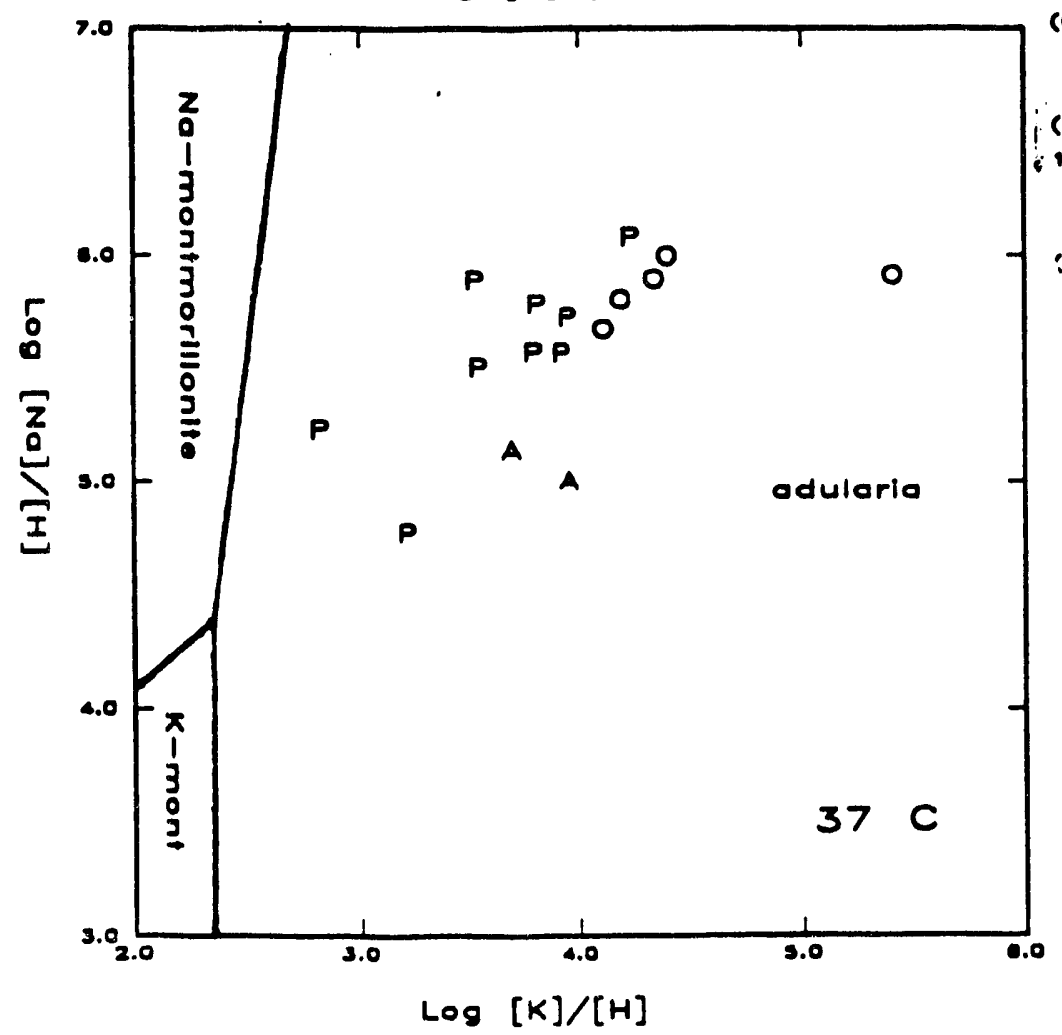

(Clesesen. 1005)

$0=$ Oosis Volley

(Molmbero ens cowin.

(1002; wnito. 1070)

$P$ = Pahute Meso

(olenkennoged and wolr, 107s)

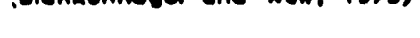



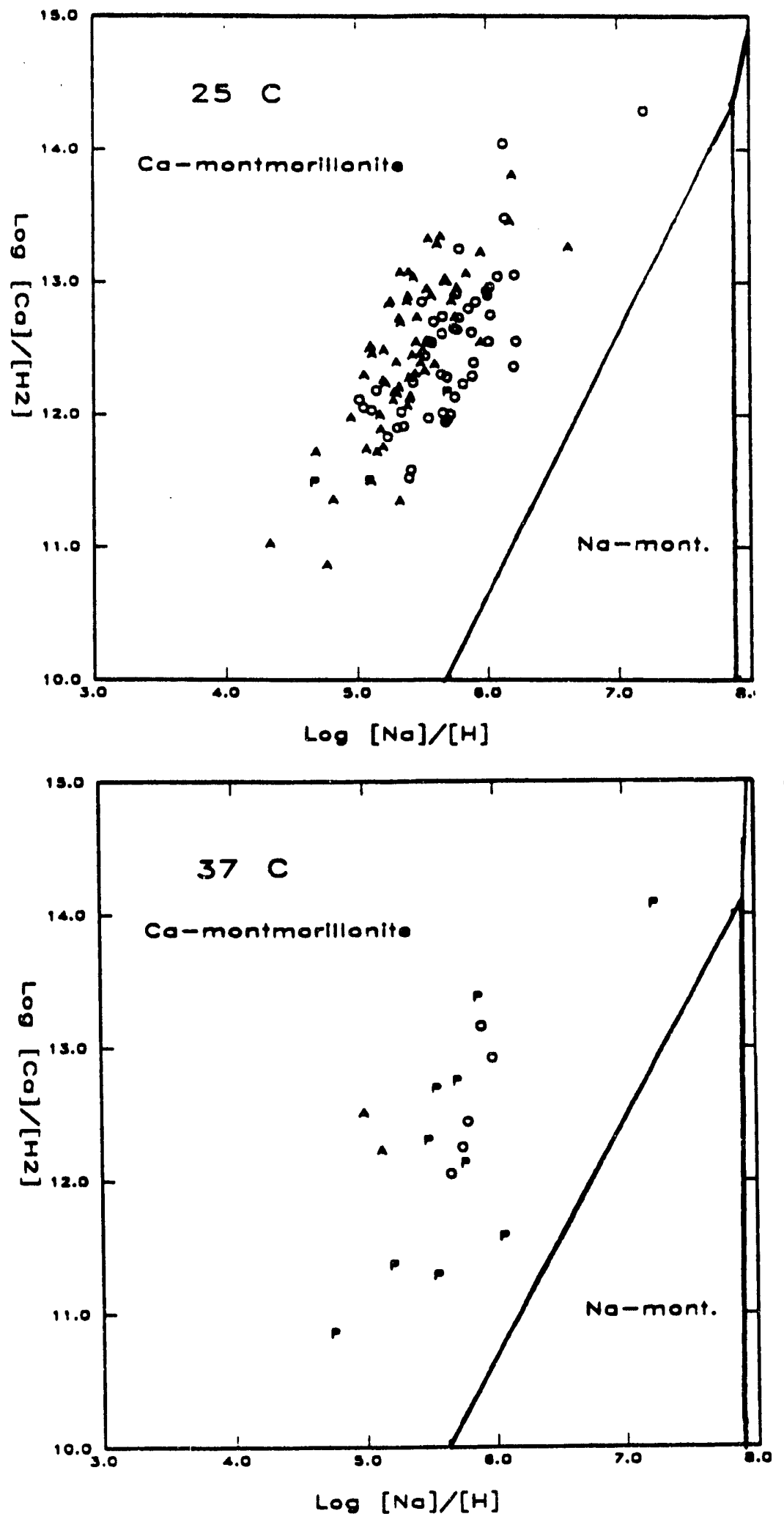

Location

$A=$ Amorooso

(Creaseon. 100s)

- Oasle Valler

crotembere ence colutn.

10e2, whilo. 1980)

$P=$ Ponute Meso

(elenmenneget ane woir. 1075)

Figure 12: Calcium-sodium mineral stability relationships of wells and springs at 1 bar pressure and $25^{\circ} \mathrm{C}$ and $37^{\circ} \mathrm{C}$, of study area in southern Nevada. 
tendency for increasing Ca-montmorillonite stability may be seen. This may be caused by two factors: either Ca-montmorillonite is thermodynamically the most stable and kinetically the most reactive mineral, and thus $\mathrm{Ca}^{2+}$ is being selectively removed from solution by $\mathrm{Ca}^{2+}$ ion exchange into montmorillonite; or there is another source of $\mathrm{Ca}^{2+}$ to the ground water which would increase $\mathrm{Ca}^{2+}$ dominance in the minerals. These sources include the weathering of carbonate detritus, underflow of ca bonate water from Bare Mountain in Oasis Valley or the regional carbonate aquifer in the Amargosa Desert.

When these $\mathrm{Na}-\mathrm{K}-\mathrm{Ca}$ mineral stability diagrams are compared to similar diagrams of Yucca Mountain well samples, it may be seen that Forty Mile Wash well samples, which are lower temperature, appear to be less evolved along a flow path, with respect to feldspar development than Oasis Valley, Amargosa Desert or other Yucca Mountain wells (Figure 13). These well data, from J-12, J-13, UE-29 a"2, UE-25 WT-14, and UE-25 WT-15, are stable within the smectite fields. One sample from well J-12 does plot in the adularia stability field; this was the first sample collected from the well, shortly after its completion. The other two J-12 samples were collected after long pumping periods. Another lower temperature well, USW H-3, is also more stable within the adularia field. At a higher temperature, $37^{\circ} \mathrm{C}$ (Figure 13), the Yucca Mountain wells all lie within the adularia stability field. Wells on the eastern flank of Yucca Mountain and the adjoining valley have higher $\mathrm{K}^{+} / \mathrm{Na}^{+}$ratios than the wells on the ridge crest and western side. This is probably caused by the selective removal of $\mathrm{K}^{+}$through the precipitation of $\mathrm{K}$-minerals and/or ion exchange along the flow path.

The relationship of $\mathrm{Na}^{+}$to $\mathrm{Ca}^{2+}$ mineral stability of Yucca Mountain water is shown in Figure 14. It may be seen that the well data at both $25^{\circ} \mathrm{C}$ 


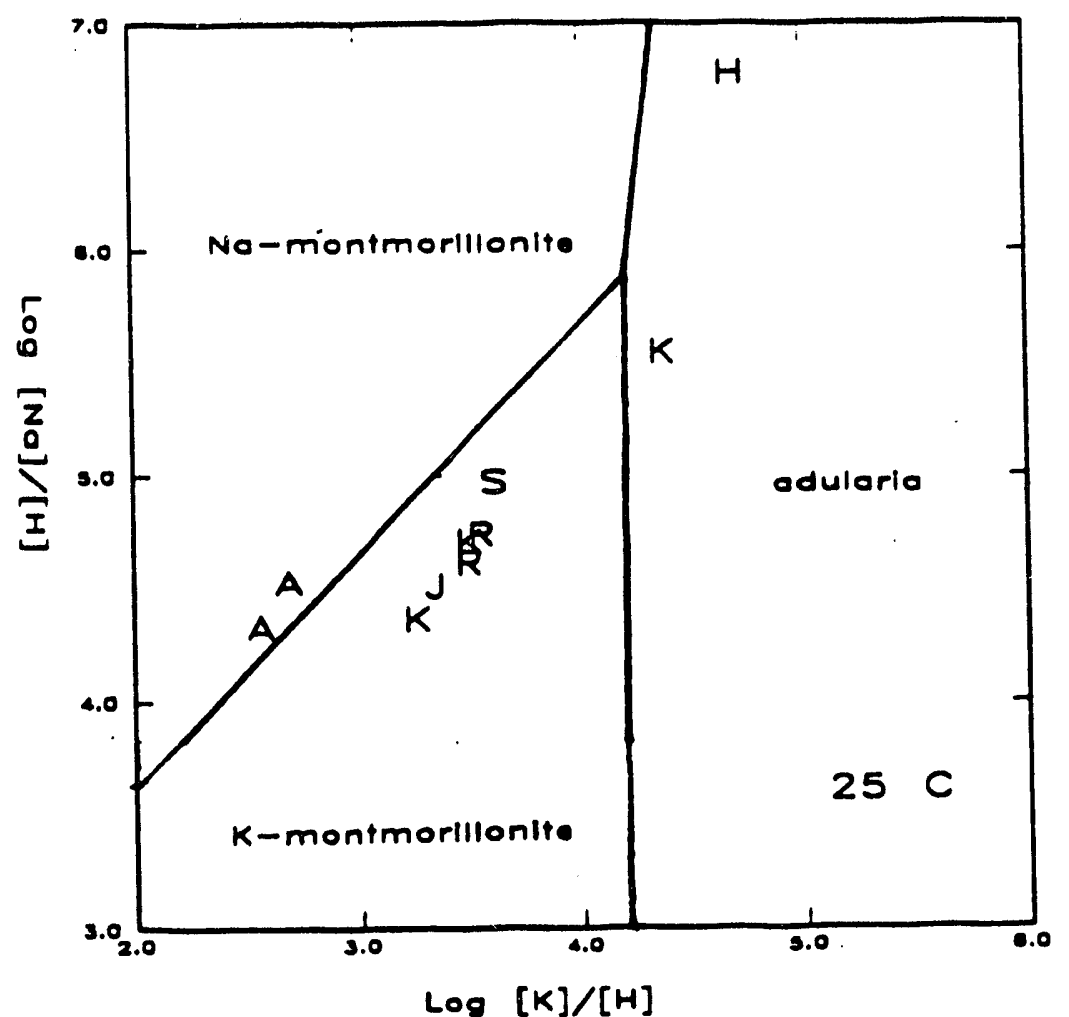

Well Name

$A=U E-29 \quad a \# 2$

$B=U E-25 \quad b \# 1$

$C=U E-25 \mathrm{C} \# 1$

$D=U E-25$ C\#2

$E=U E-25 \quad 0 \# 3$

$F=$ USW $\mathrm{H}-1$

$G=U S W \quad G-4$

$H=$ USW $\mathrm{H}-3$

$J=J-13$
$K=J-12$

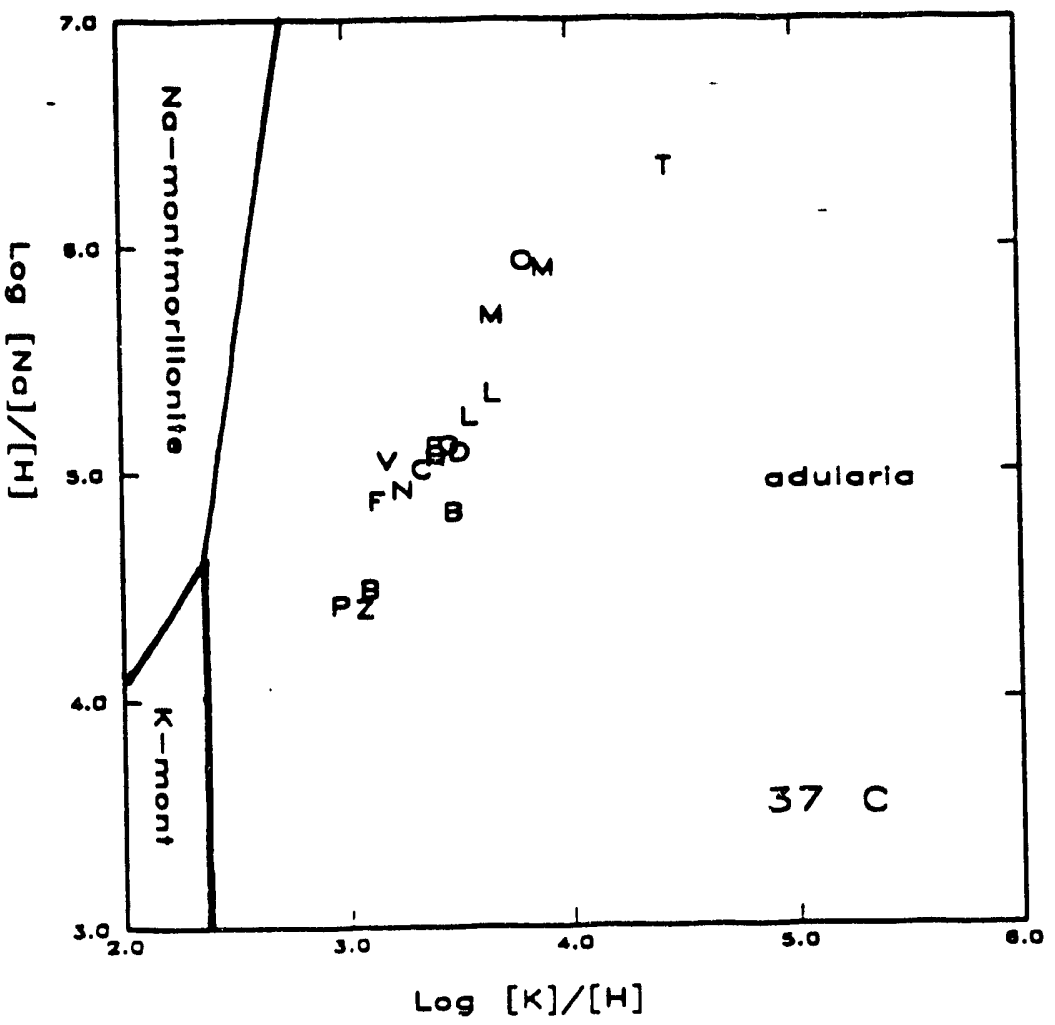

$L=U S W H-5$

$M=$ USW $H-6$

$N=U S W H-4$

$0=U S W W T-10$

$P=U E-25$ PHI (VOl)

$Q=U E-25 W T-12$

$R=U E-25 W T-14$

$S=U E-25 W T-15$

$T=U S W$ WT-7

$V=$ USW VH-1

$Z=U E-25 P \# 1$

(carbonate aquifer)

Dato From:

Deneon and Mekinley,

1985: Matulka. 1988

Figure 13: Sodium-potassium mineral stability relationships of wells at 1 bar pressure and $25^{\circ} \mathrm{C}$ and $37^{\circ} \mathrm{C}$, Yucca Mountain, Nevada. 

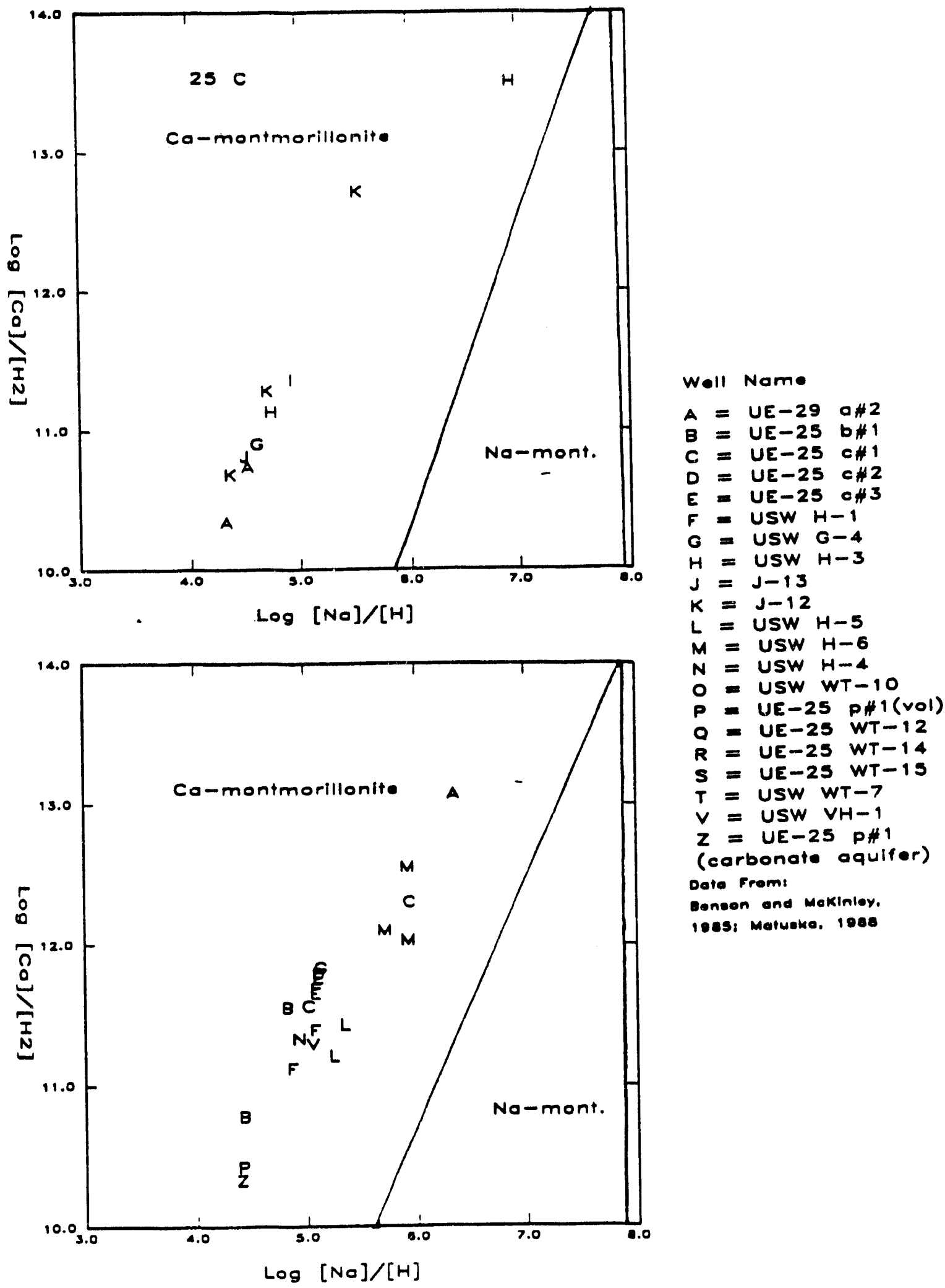

Figure 14: Calcium-sodium mineral stability relationships of wells at 1 bar pressure and $25^{\circ} \mathrm{C}$ and $37^{\circ} \mathrm{C}$, Yucca Mountain. Nevada. 
and $37^{\circ} \mathrm{C}$ are located within the Ca-montmorillonite stability field. Again, this may be caused either by selective removal of $\mathrm{Ca}^{2+}$ by ion exchange in montmorillonite, or an increase in the $\mathrm{Ca}^{2+}$ content from input of carbonate aquifer ground water. Figure 15 suggests that the source of the $\mathrm{Ca}$ montmorillonite is selective removal of $\mathrm{Ca}^{2+}$, and not the addition of carbonate ground water.

Figure 15 shows the relationship of the saturation index of $\mathrm{Ca}$ montmorillonite to the partial pressure of $\mathrm{CO}_{2}$. Along a northwest-southeast flow path in the volcanic tuffs, which is indicated by the hydraulic gradient (Robison, 1984), there is a tendency for an increase of Ca-montmorillonite saturation with a slight increase in $\mathrm{P}_{\mathrm{CO}_{2}}$. In contrast, well UE-25 $\mathrm{p}^{\#} 1$, which has an upward hydraulic gradient from the carbonate aquifer, shows a decrease in Ca-montmorillonite saturation with an increase in $\mathrm{P}_{\mathrm{CO}_{2}}$. Therefore, the apparent dominance of $\mathrm{K}^{+}$and $\mathrm{Ca}^{2+}$ removal by ion exchange in the montmorillonites, which in turn releases $\mathrm{Na}^{+}$, at Yucca Mountain agrees with the flow path evolution given by Claassen and White (1979) and White et al. (1980) when they proposed that montmorillonites were providing a sink for $\mathrm{K}^{+}$and $\mathrm{Ca}^{2+}$ cations within Rainier Mesa.

From the initial analysis of Yucca Mountain wells using WATEQDR, the following four points may be made:

1. Yucca Mountain ground water is supersaturated with respect to montmorillonites, illites, feldspars and quartz polymorphs.

2. The ground water is undersaturated with respect to analcime and calcite.

3. Water samples from wells in Forty Mile Wash are of low temperature and are generally stable with respect to smectites. This suggests that the water in this area is less evolved than is the water from Yucca Mountain, Oasis Valley or Amargosa Desert, and that this area may be a recharge zone. 


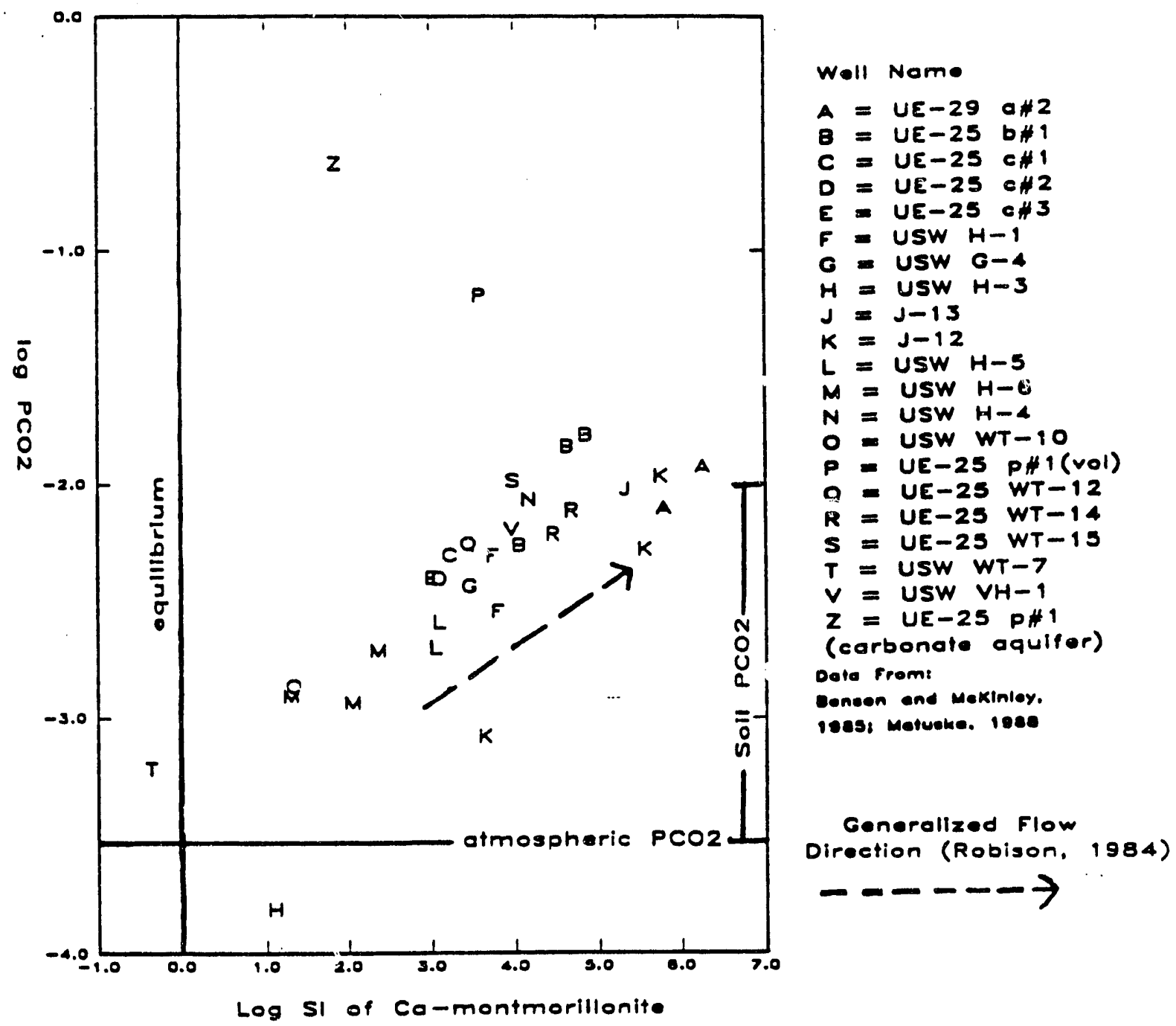

Figure 15: Saturation index of Ca-montmorillonite compared to the partial pressure oi $\mathrm{CO}_{2}$ along a flow path at Yucca Mountain, Nevada.

4. The dominance of $\mathrm{Na}^{+}$in solution is from the selective removal of $\mathrm{K}^{+}$and $\mathrm{Ca}^{2+}$ through precipitation of $\mathrm{K}$-feldspars and (K, $\mathrm{Ca}$ ) ion exchange with montmorillonites. 



\section{PHREEQE GEOCHEMICAL MODEL}

\section{Geochemical Model Input}

The hypothetical geochemical flow path developed in PHREEQE consisted of six zones which correlate to initial recharge through the soil and a downward travel path through the diagenetic mineral zones discussed previously. In each zone a reaction step releases ions into the initial solution to form a new solution. This new solution then interacts with specified minerals, which undergo congruent dissolution, until equilibrium is attained with the first mineral phase listed.

The ground-water flow path model of Yurca Mountain was divided into five parts that are based upon the four diagenetic mineral zones described by Broxton et al. (1986). Each part is characterized by a specific mineral assemblage, temperature, initial solution and reaction step that produce the final solution. The diagenetic mineral Zone II was divided into two regions in this model.

The initial solution is the chemical analysis of the starting solution from a well, soil or previous zone. Included in the solution input are chemical analyses of major ions $\left(\mathrm{Na}^{+}, \mathrm{K}^{+}, \mathrm{Ca}^{2+}, \mathrm{Mg}^{2+}, \mathrm{HCO}_{3}^{-}, \mathrm{SO}_{4}^{2-}, \mathrm{SiO}_{2}, \mathrm{Cl}^{-}\right)$in $\mathrm{mg} / \mathrm{l}$, and $\mathrm{pH}$, pe and temperature. In the data from Yucca Mountain wells (Benson and McKinley, 1985), no aluminum values are reported. Because aluminum is an important cation for aluminosilicate reactions, such as those involving zeolites and smectites, an $\mathrm{Al}^{3+}$ value of $0.047 \mathrm{mg} / \mathrm{l}$ was set for the Yucca Mountain well initial solutions. This value is derived from previous $\mathrm{Al}^{3+}$ analyses of wells $\mathrm{J}-11$ and J-12, reported by Moore (1961). The aluminum values used in the modeled 
tuffaceous flow path come entirely from the dissolution of the aluminosilicaterich volcanic glass.

The reaction step is an ion suite or phase that was reacted with the solution and subsequent mineral phases. This phase is either the most chemically reactive phase present, such as a volcanic glass, or else composed the largest volume percentage of the rock unit, as in the case of the zeolites. In the first part of the flow path model, the reaction step is the complete dissolution of a volcanic glass, whereas in subsequent parts the reaction step is an ion exchange within zeolites and consists of ions $\left(\mathrm{Na}^{+}, \mathrm{K}^{+}, \mathrm{Ca}^{2+}\right)$ that are released into solution. The resultant solution formed from reactions and mineral dissolutions and precipitations in each part is used as the starting solution in the next region.

Temperature is increased with each subsequent zone, based on the assumption of increasing temperature with depth. In the inital part of the model, temperature is $25^{\circ} \mathrm{C}$, and increases to $40^{\circ} \mathrm{C}$ by Part V.

The mineral assemblages used in each section are those defined by the diagenetic mineral zones of Broxton et al. (1986), and consists of zeolites, smectites, feldspars and quartz polymorphs. Because of limitations of the thermodynamic data base, the zeolites and smectites used are end-members, such as $\mathrm{Na-montmorillonite,} \mathrm{rather} \mathrm{than} \mathrm{mixed-cation} \mathrm{minerals} \mathrm{(i.e.} \mathrm{Na-K),} \mathrm{which} \mathrm{would}$ be more representative of minerals present. This results in differences between the flow path model and the actual tuffaceous system. Unfortunately, there are no mixed-cation thermodynamic data to resolve this problem and determine the amount of differences these end-members may make in the model. No sources or sinks for the anions $\mathrm{Cl}^{-}$or $\mathrm{SO}_{4}^{2-}$ were included in the flow path model because the necessary mineral phases were either not identified in the formations or were not discussed in the literature. 
In each part of the model PHREEQE, calculations are run until the first mineral in the given list reaches equilibrium. The minerals which are assumed to be at equilibrium are various polymorphs of quartz because WATEQDR analysis showed these minerals to be ubiquitous and near equilibrium in most of the Yucca Mountain wells. Formulas and thermodynamic properties of the mineral phases used by PHREEQE in the model are listed in Table 5. These data were taken from an uncritical summary published by Woods and Garrels (1987), and selected for their similarity to thermodynamic data used in WATEQ, as published by Truesdell and Jones (1974).

\section{Geochemical Flow Path Model}

The following hypothetical flow path was assumed to be the most representative model of ground-water flow through the volcanic tuffs of Yucca Mountain. Table 6 lists the properties of each modeled zone.

Part I: This domain coincides with the diagenetic mineral Zone I, as described by Broxton et al. (1986). This is the uppermost zone, entirely above the water table, and thus is modeled as an open system, with $\mathrm{CO}_{2}$ exchanging freely with the atmosphere. The initial solution, considered to be from recharging soil water, is an analysis of a sample collected by Henne (1982) with a suction lysimeter on Rainier Mesa, and is considered similar to recharge at Yucca Mountain. The initial solution is sodium/calcium-rich. This solution reacts with the dissolution of volcanic glass, as described by Broxton et al. (1986), and the minerals cristobalite, Na-montmorillonite and heulandite. The model runs until cristobalite reaches equilibrium. At this point, Na-montmorillonite is dissolving into solution and heulandite is precipitating. 


\begin{tabular}{|c|c|c|c|c|}
\hline \multicolumn{5}{|c|}{$\begin{array}{c}\text { TABLE } 6 \\
\text { TUFFACEOUS WATER CHEMISTRY ZONES MODELED IN PHREEQE }\end{array}$} \\
\hline Part & Reaction & Phases & Molality & $\mathrm{pH} ; \log \mathrm{P}_{\mathrm{CO}_{2} ;} \mathrm{T}$ \\
\hline $\begin{array}{c}\text { Initial } \\
\text { Solution }\end{array}$ & Soil & Soil & $\begin{array}{l}\mathrm{Ca}=1.84 \times 10^{-1} \\
\mathrm{Mg}=8.88 \times 10^{-6} \\
\mathrm{Na}=1.37 \times 10^{-3} \\
\mathrm{~K}=8.03 \times 10^{-5} \\
\mathrm{C}=1.72 \times 10^{-3} \\
\mathrm{Si}=3.99 \times 10^{-1}\end{array}$ & $\begin{array}{l}\mathrm{pH}: \mathrm{i.2} \\
\log \mathrm{P}_{\mathrm{CO}_{2}}: \\
-2.17 \\
\mathrm{~T}: 25^{\circ} \mathrm{C}\end{array}$ \\
\hline I & $\begin{array}{l}\text { Dissolution } \\
\text { of } \\
\text { Volcanic } \\
\text { Glass }\end{array}$ & $\begin{array}{l}\text { cristobalite } \\
\text { Na-montmorillonite } \\
\text { heulandite } \\
\log \mathrm{P}_{\mathrm{CO}_{2}}\end{array}$ & $\begin{array}{l}\mathrm{Ca}=2.17 \times 10^{-5} \\
\mathrm{Mg}=8.88 \times 10^{-5} \\
\mathrm{Na}=1.47 \times 10^{-3} \\
\mathrm{~K}=8.03 \times 10^{-6} \\
\mathrm{C}=3.57 \times 10^{-2} \\
\mathrm{Si}=2.05 \times 10^{-4}\end{array}$ & $\begin{array}{l}\mathrm{pH}: 5.0 \\
\log \mathrm{P}_{\mathrm{CO}_{2}}: \\
0.00 \\
\mathrm{~T}: 25^{\circ} \mathrm{C}\end{array}$ \\
\hline II & $\begin{array}{c}\text { Clinoptilolite } \\
\text { Ion } \\
\text { Exchange } \\
2 \mathrm{Na}: 2 \mathrm{~K}: 1 \mathrm{Ca} \\
\text { (moles) }\end{array}$ & $\begin{array}{l}\text { cristobalite } \\
\text { Na-montmorillonite } \\
\text { adularia }\end{array}$ & $\begin{array}{l}\mathrm{Ca}=5.29 \times 10^{-3} \\
\mathrm{Mg}=8.88 \times 10^{-5} \\
\mathrm{Na}=1.20 \times 10^{-2} \\
\mathrm{~K}=1.06 \times 10^{-2} \\
\mathrm{C}=3.57 \times 10^{-2} \\
\mathrm{Si}=2.38 \times 10^{-4}\end{array}$ & $\begin{array}{l}\text { pH: } 7.3 \\
\log \mathrm{P}_{\mathrm{CO}_{2}}: \\
-1.04 \\
\mathrm{~T}: 30^{\circ} \mathrm{C}\end{array}$ \\
\hline III & $\begin{array}{l}\text { Mordenite } \\
\text { Ion } \\
\text { Exchange } \\
2 \mathrm{Na:2K} \\
\text { (moles) }\end{array}$ & $\begin{array}{l}\text { cristobalite } \\
\text { Na-montmorillonite } \\
\text { K-montmorillonite } \\
\text { adularia }\end{array}$ & $\begin{array}{l}\mathrm{Ca}=5.28 \times 10^{-3} \\
\mathrm{Mg}=8.88 \times 10^{-6} \\
\mathrm{Na}=2.97 \times 10^{-2} \\
\mathrm{~K}=5.43 \times 10^{-4} \\
\mathrm{C}=3.57 \times 10^{-2} \\
\mathrm{Si}=2.90 \times 10^{-4}\end{array}$ & $\begin{array}{l}\mathrm{pH}: 8.9 \\
\log \mathrm{P}_{\mathrm{CO}_{2}}: \\
-2.16 \\
\mathrm{~T}: 32 \cdot \mathrm{C}\end{array}$ \\
\hline IV & $\begin{array}{l}\text { Analcime } \\
\text { Ion } \\
\text { Exchange } \\
6 \mathrm{Na:2 \textrm {K }} \\
\text { (moles) }\end{array}$ & $\begin{array}{l}\text { quartz } \\
\text { Na-montmorillonite } \\
\text { K-montmorillonite } \\
\text { Ca-montmorillonite }\end{array}$ & $\begin{array}{l}\mathrm{Ca}=3.35 \times 10^{-2} \\
\mathrm{Mg}=8.88 \times 10^{-6} \\
\mathrm{Na}=1.51 \times 10^{-6} \\
\mathrm{~K}=2.86 \times 10^{-7} \\
\mathrm{C}=3.57 \times 10^{-2} \\
\mathrm{Si}=5.62 \times 10^{-4}\end{array}$ & $\begin{array}{l}\mathrm{pH}: 10.1 \\
\log \mathrm{P}_{\mathrm{CO}_{2}}: \\
-4.56 \\
\mathrm{~T}: 35 \cdot \mathrm{C}\end{array}$ \\
\hline $\mathbf{V}$ & $\begin{array}{c}\text { No } \\
\text { Reaction } \\
\text { Step }\end{array}$ & $\begin{array}{l}\text { chalcedony } \\
\text { illite } \\
\text { chlorite } \\
\text { adularia } \\
\text { albite } \\
\text { calcite } \\
\end{array}$ & $\begin{array}{l}\mathrm{Ca}=1.57 \times 10^{-6} \\
\mathrm{Mg}=8.53 \times 10^{-8} \\
\mathrm{Na}=3.46 \times 10^{-3} \\
\mathrm{~K}=1.37 \times 10^{-6} \\
\mathrm{C}=2.23 \times 10^{-3} \\
\mathrm{Si}=8.28 \times 10^{-4}\end{array}$ & $\begin{array}{l}\mathrm{pH}: 9.5 \\
\log \mathrm{P}_{\mathrm{CO}_{2}}: \\
-4.39 \\
\mathrm{~T}: 40^{\circ} \mathrm{C}\end{array}$ \\
\hline $\mathrm{UE}-25 \mathrm{p \# 1}$ & $\begin{array}{c}\text { Lower } \\
\text { Carbonate } \\
\text { Aquifer }\end{array}$ & $\begin{array}{l}\text { dolomite } \\
\text { calcite } \\
\text { chalcedony } \\
\text { iron oxides }\end{array}$ & $\begin{array}{l}\mathrm{Ca}=2.48 \times 10^{-3} \\
\mathrm{Mg}=1.61 \times 10^{-3} \\
\mathrm{Na}=6.32 \times 10^{-3} \\
\mathrm{~K}=3.07 \times 10^{-4} \\
\mathrm{C}=9.36 \times 10^{-3} \\
\mathrm{Si}=6.84 \times 10^{-4}\end{array}$ & $\begin{array}{l}\mathrm{pH}: 6.6 \\
\log \mathrm{P}_{\mathrm{CO}_{2}}: \\
-0.62 \\
\mathrm{~T}: 56^{\circ} \mathrm{C}\end{array}$ \\
\hline
\end{tabular}

* UE-25 p\#1 data from Benson and McKinley, 1985. 
This results in the removal of calcium from the solution, and addition of sodium. Because the system is modeled as open, the subsequent addition of $\mathrm{CO}_{2}$ and carbonic acid lowers the $\mathrm{pH}$ from 7.2 to 5.0. Temperature is held constant at $25^{\circ} \mathrm{C}$.

Part II: The upper region of the diagenetic mineral Zone II is modeled as Part II of the flow path model. This zone is found both above and below the water table, therefore very little volcanic glass is present. The system is modeled as closed to atmospheric $\mathrm{CO}_{2}$ addition, as suggested by White and Chuma (1987), because of the several hundred meter depth to the water table. The resultant solution of Part I interacts with clinoptilolite as an ion-exchange which releases one mole $\mathrm{Ca}^{2+}$ and two moles each $\mathrm{Na}^{+}$and $\mathrm{K}^{+}$. The reaction proceeds until equilibrium with cristobalite, Na-montmorillonite and adularia is attained, and the temperature reaches $30^{\circ} \mathrm{C}$. After reacting with these minerals, the resulting solution is enriched in $\mathrm{Na}^{+}$and $\mathrm{K}^{+}$, which are released from the clinoptilolite. Molality of $\mathrm{Ca}^{2+}$ increases from the previous zone, but the solution chemistry is still dominated by the monovalent cations. Adularia is dissolving at approximately twice the rate that Na-montmorillonite is precipitating. Because carbonic acid is decreasing, the $\mathrm{pH}$ increased to 7.3.

Part III: The lower portion of diagentic mineral Zone II is modeled as Part III and lies entirely below the water table in all wells on Yucca Mountain. Mordenite reacts as an ion exchange by releasing two moles of $\mathrm{Na}^{+}$and $\mathrm{K}^{+}$. Other minerals present are cristobalite, Na-montmorillonite, Kmortmo:illonite and adularia. Temperature is increased to $32^{\circ} \mathrm{C}$. The reaction proceeds until cristobalite equilibrium is reached, at which point Na-montmorillonite is dissolving (releasing $\mathrm{Na}^{+}$) at about the same rate 
that $\mathrm{K}$-montmorillonite is precipitating (removing $\mathrm{K}^{+}$). This apparent end-member dissolution and precipitation is probably a simple ion exchange of $\mathrm{K}^{+}$for $\mathrm{Na}^{+}$, rather than complete mineral formation. The resultant solution is greatly enriched in $\mathrm{Na}^{+}$and $\mathrm{Ca}^{2+}$, and depleted in $\mathrm{K}^{+}$. The $\mathrm{pH}$ increases to $\mathbf{8 . 9}$.

Part IV: This part contains quartz, analcime and the $(\mathrm{Na}, \mathrm{Ca}, \mathrm{K})$ end-member montmorillonites found in the diagenetic mineral Zone III. Analcime releases six moles $\mathrm{Na}^{+}$and two moles $\mathrm{K}^{+}$into the final solution from Part III. $\mathrm{Ca}$ is exchanging for $\mathrm{Na}$ in montmorillonite in subequal quantities: subsequently, the resulting solution becomes $\mathrm{Ca}^{2+}{ }_{-}$-rich, and depleted in $\mathrm{Na}^{+}$ and $\mathrm{K}^{+}$. The $\mathrm{pH}$ increases to 10.1 .

Part V: The solution in this part reacts equally with all minerals present, because the diagenetic mineral Zone IV as described by Broxton et al. (1986) has few zeolites, compared to other minerals. The final section is modeled instead with no specific reaction step, such as ion exchange, occurring. The original volcanic mineralogy of Zone IV has been replaced by secondary chalcedony, illite, chlorite, adularia, albite and calcite. After interaction with this mineral suite, the temperature increases to $40^{\circ} \mathrm{C}$, the resulting solution becomes $\mathrm{Na}^{+}$-rich, with $\mathrm{K}^{+}$and $\mathrm{Ca}^{2+}$ subequal, and depleted in $\mathrm{Mg}^{2+}$. Chalcedony, illite and calcite are precipitating, and chlorite and the feldspars are dissolving. The $\mathrm{pH}$ decreases to 9.5 , and the partial pressure of $\mathrm{CO}_{2}$ is -4.4 . 


\section{Geochemical Modeling Results}

The objective of the geochemical modeling is to construct a theoretical flow path that will describe the chemical changes in a ground water solution as it traveled through a tuffaceous aquifer.

The initial soil water input into the model is an $\mathrm{Na}^{+}-\mathrm{Ca}^{2+}$-rich solution with a $\mathrm{pH}$ of 7.2. Along the flow path, the solution reacted with the dissolution of volcanic glass, and ion exchange of $\mathrm{Na}^{+}-\mathrm{K}^{+}-\mathrm{Ca}^{2+}$ with zeolites and smectites. Because of the great depth to the water table, except for the first zone, the system is modeled as closed to atmospheric exchange; subsequently, the $\mathrm{P}_{\mathrm{CO}_{2}}$ decreases and $\mathrm{pH}$ increases along the flow path. In the final zone, Part $\mathrm{V}$, the reaction with calcite adds a minor amount of $\mathrm{CO}_{2}$ to the system. The most reactive minerals are the smectites, zeolites and feldspars, and the solution becomes alternately either $\mathrm{Na}^{+}-$or $\mathrm{Ca}^{2+}$-rich, dependent upon the mineral stabilities. By the final zone, Part $\mathrm{V}$, the solution is $\mathrm{Na}^{+}$-rich, with subequal amounts of $\mathrm{Ca}^{2+}-\mathrm{K}^{+}$, and is depleted in $\mathrm{Mg}^{2+}$. Chalcedony, illite and calcite are precipitating, and chlorite and feldspars are dissolving.

Graphical analyses of the data show the differences between the modeled zones and the samples from the Yucca Mountain wells (Figures 16 and 17). The initial input, from the Rainer Mesa soil (Henne, 1982) is very similar in chemical composition to the Yucca Mountain wells. In the next four zones, the ionic concentration increases in the solution, especially $\mathrm{Ca}^{2+}$, are the greatest difference between the model and Yucca Mountain well samples. The large amount of mineral reactions, coupled with no reaction step, removes the majority of the ions from the solution in Part V. The concentration of the ions in solution decreases from nearly 40 equivalents per million (EPM) to less than 6 EPM, which is similar to the Yucca Mountain samples (Figures 16 and 17). 


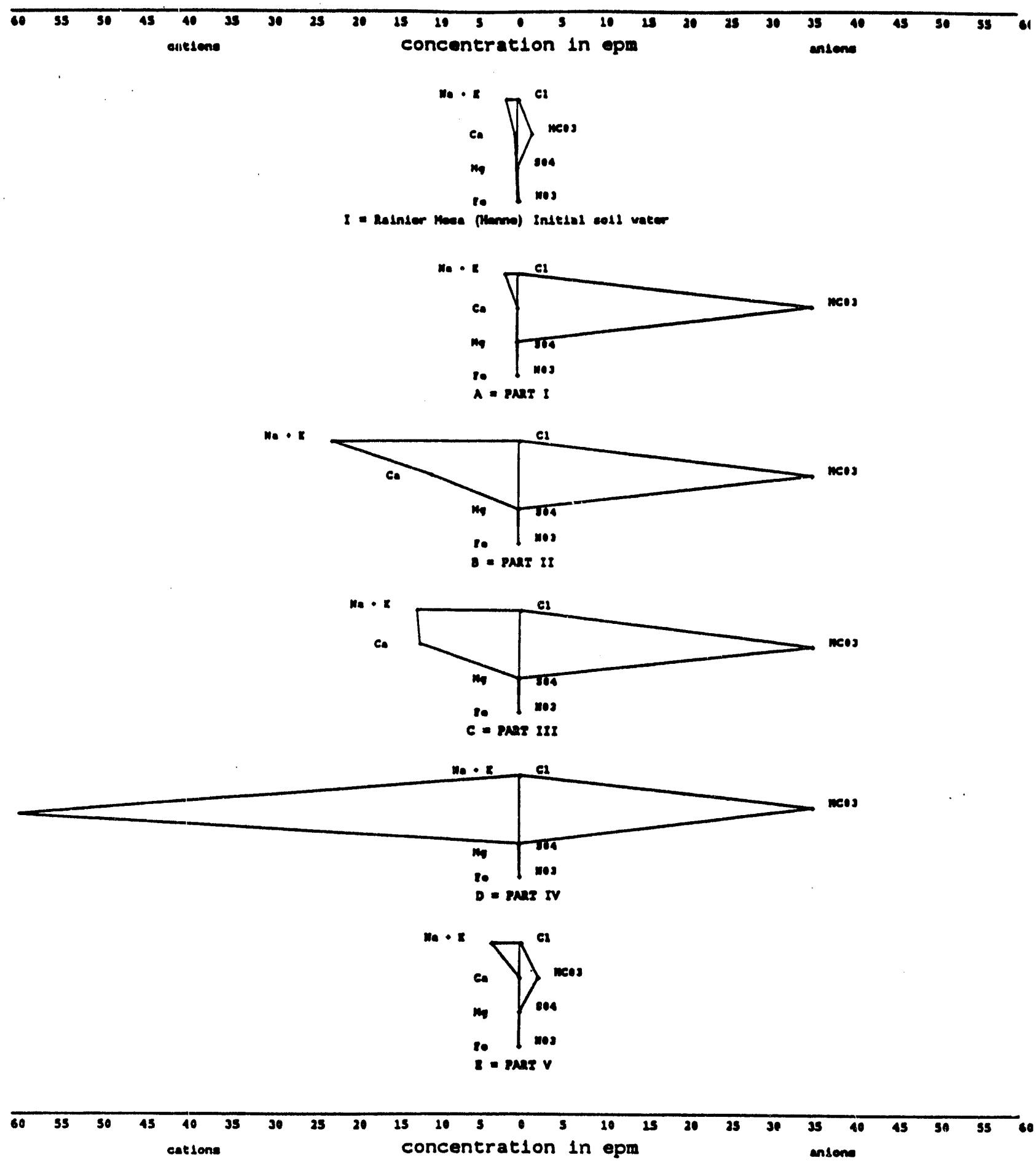

Figure 16: Chemical analyses of geochemical flow path modeled zones in volcanic aquifers at Yucca Mountain, Nevada. Scale is to 60 EPM. 


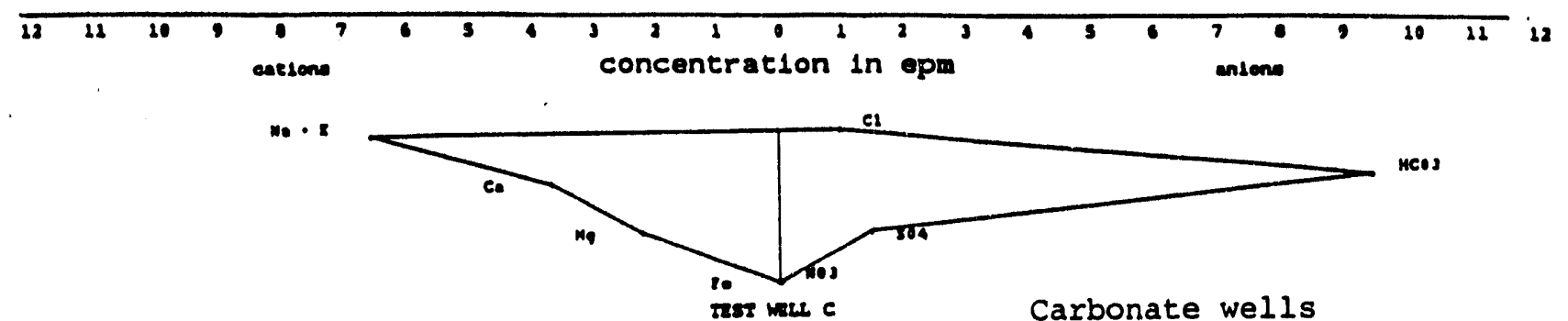

...

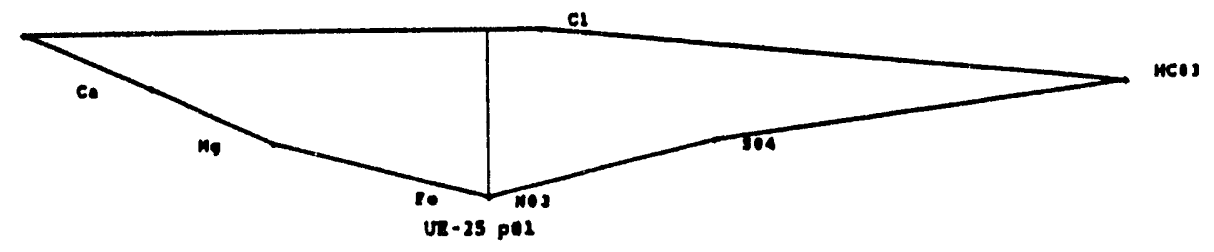

ma. $\cdot \mathbf{a}$

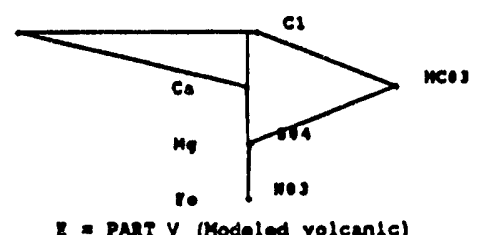

I - past v (Modeled volcanle)

m. $x$

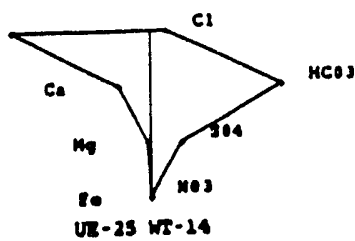

告

- $x$

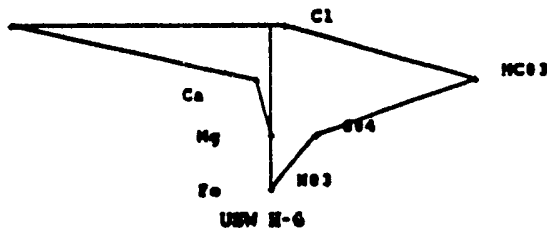

m.

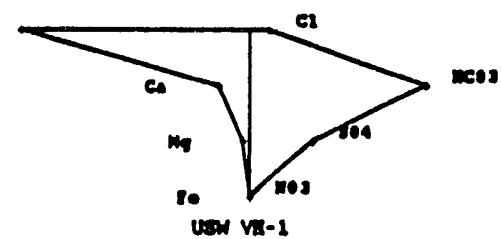

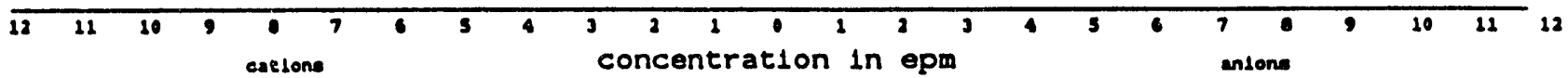

Figure 17: Chemical analyses of Yucca Mountain wells, Part V modeled zone and carbonate wells surrounding Yucca Mountain, Nevada. Scale is to 12 EPM. 
The STIFF diagrams of Figure 17 show differences between the Yucca Mountain wells and some of the carbonate wells of the NTS. The carbonate wells show a distinct pattern of $\mathrm{Ca}^{2+}+\mathrm{Mg}^{2+}>\mathrm{Na}^{+}+\mathrm{K}^{+}$. The opposite is true of the Yucca Mountain wells; Part V of the modeled zone follows the latter pattern. Because of this pattern, and low ionic concentration, Part V was selected as the most representative of a a volcanic water at Yucca Mountain.

When the results of the modeled Part II - Part V are plotted on mineral stability diagrams (points 2-5, Figures 18 and 19), the increase in the cation concentration along the modeled flow path is again visible. The large input of calcium and subsequent decrease in sodium concentration in Part IV is the result of $\mathrm{Na}^{+}$ions substituting into the montmorillonite molecule for $\mathrm{Ca}^{2+}$ ions. This release of extra $\mathrm{Ca}^{2+}$ ions makes the solution very calcium rich, and the data for Part IV plot off the scale in Figure 19. With no ion-exchange cation input occurring in Part V, the resultant mineral reactions tend to remove the excess $\mathrm{Ca}^{2+}$ and bring the cation concentrations to a more reasonable level. Overall, the solution modeled in Part V is most similar to well USW H-3 (point $\mathrm{H}$, Figures 18 and 19). Part $\mathrm{V}$ is also similar to another high $\mathrm{pH}$ well, USW WT-10, with respect to $\mathrm{pH}$ and saturation indices of minerals (Table 7).

When $\mathrm{pH}$, constituent molalities, ionic log activity and saturation indices of minerals from the five zones are compared, Part $\mathrm{V}$ again is most similar to Yucca mountain samples (Tables 6 and 8). While the other modeled zones may be similar to the Yucca Mountain wells in one parameter (i.e., pH or SI of a mineral phase), differences arise when all the parameters are compared. The greatest difference appears to be in $\mathrm{pH}$ and calcite saturation. Most of the Yucca Mountain well analyses are lower in $\mathrm{pH}$ and calcite saturation than what the modeled zones predict. This is a problem with the proposed flow path model which is probably caused by the way the ion-exchanged elements, $\mathrm{CO}_{2}$, and 


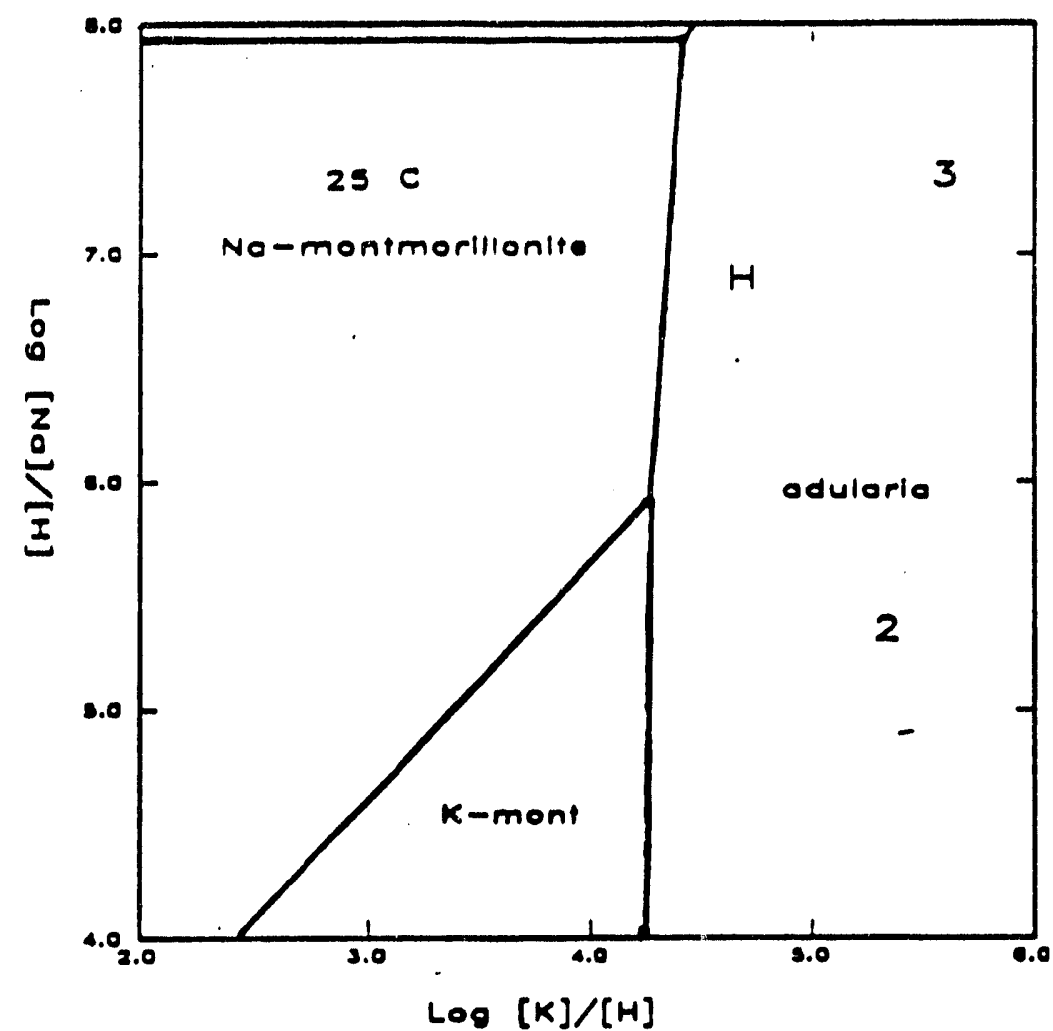

Well Somples and Models

$H=$ USW $\mathrm{H}-3$

0 = Modoled $\mathrm{H}-3$

$P$ = UE-2S PHI

$x=$ Modeled $p \# 1$

PHREEQE MOdeled Zones

+2 = Port 11

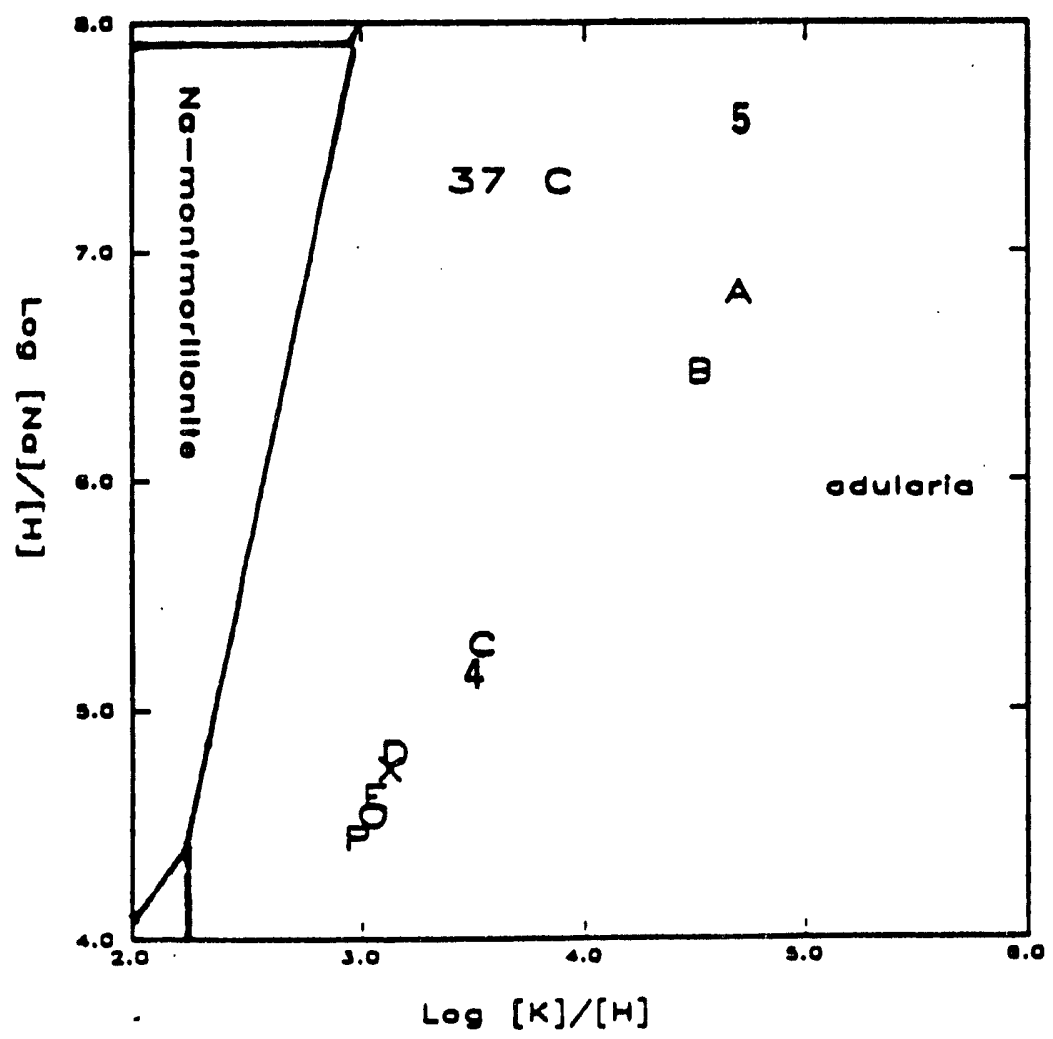

3 a Port III

4 = Port IV

5 - port $V$

Modoled Mixture Ratios (Part V/Corbonate)
$A=95 / 5$
$\theta=90 / 10$
$c=80 / 20$
D $=70 / 30$
$E=60 / 40$

Figure 18: Sodium-potassium mineral stability relationships of flow path model compared to Yucca Mountain, Nevada, wells at 1 bar pressure and $25^{\circ} \mathrm{C}$ and $37^{\circ} \mathrm{C}$. 


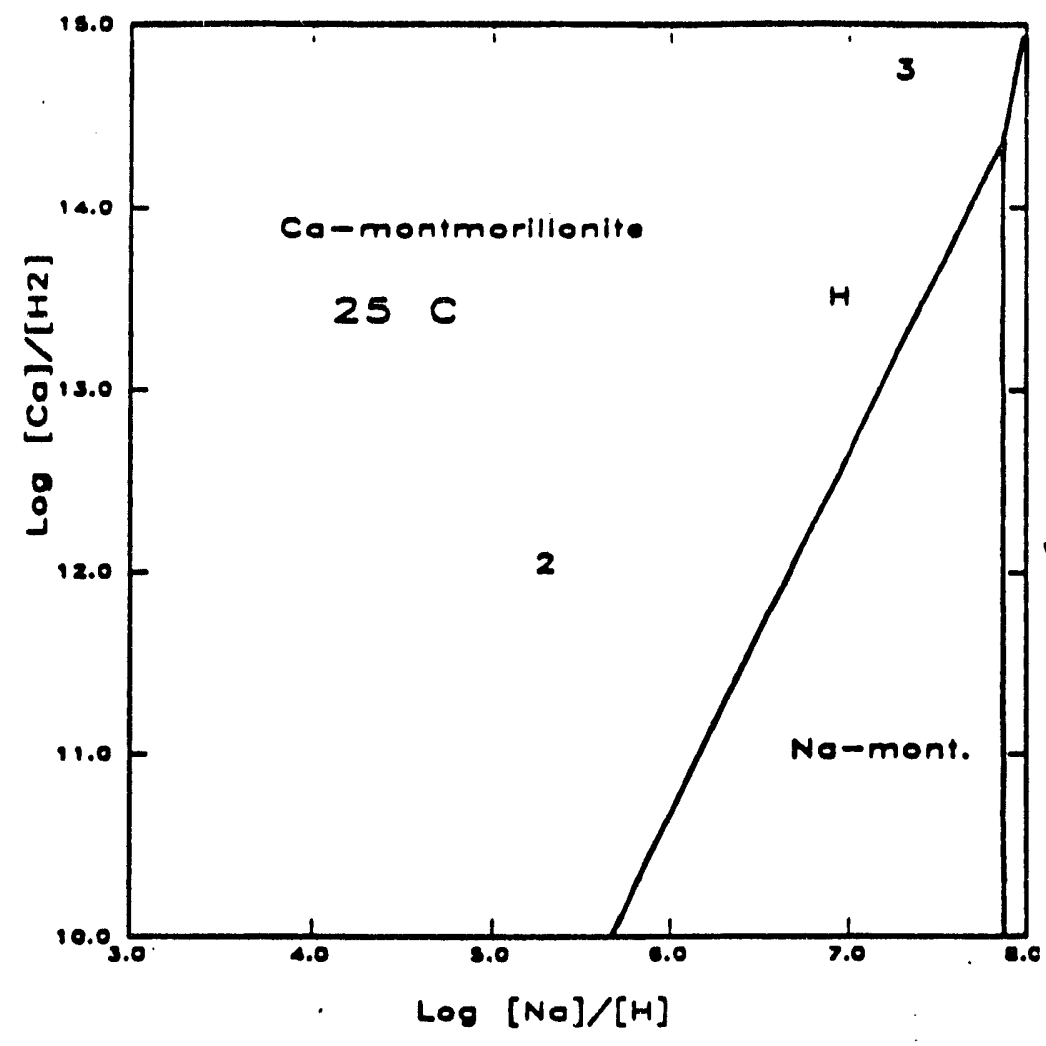

Well Samples and Models

$H=U S W H-3$

O = Modeled $\mathrm{H}-3$

$P=U E-2 S$ PH

$x=$ Modoled P\#I

PHREEQE MOdoled Zones

2 = Port 11

3 = Part III

4 = Part IV

5 - Part $V$

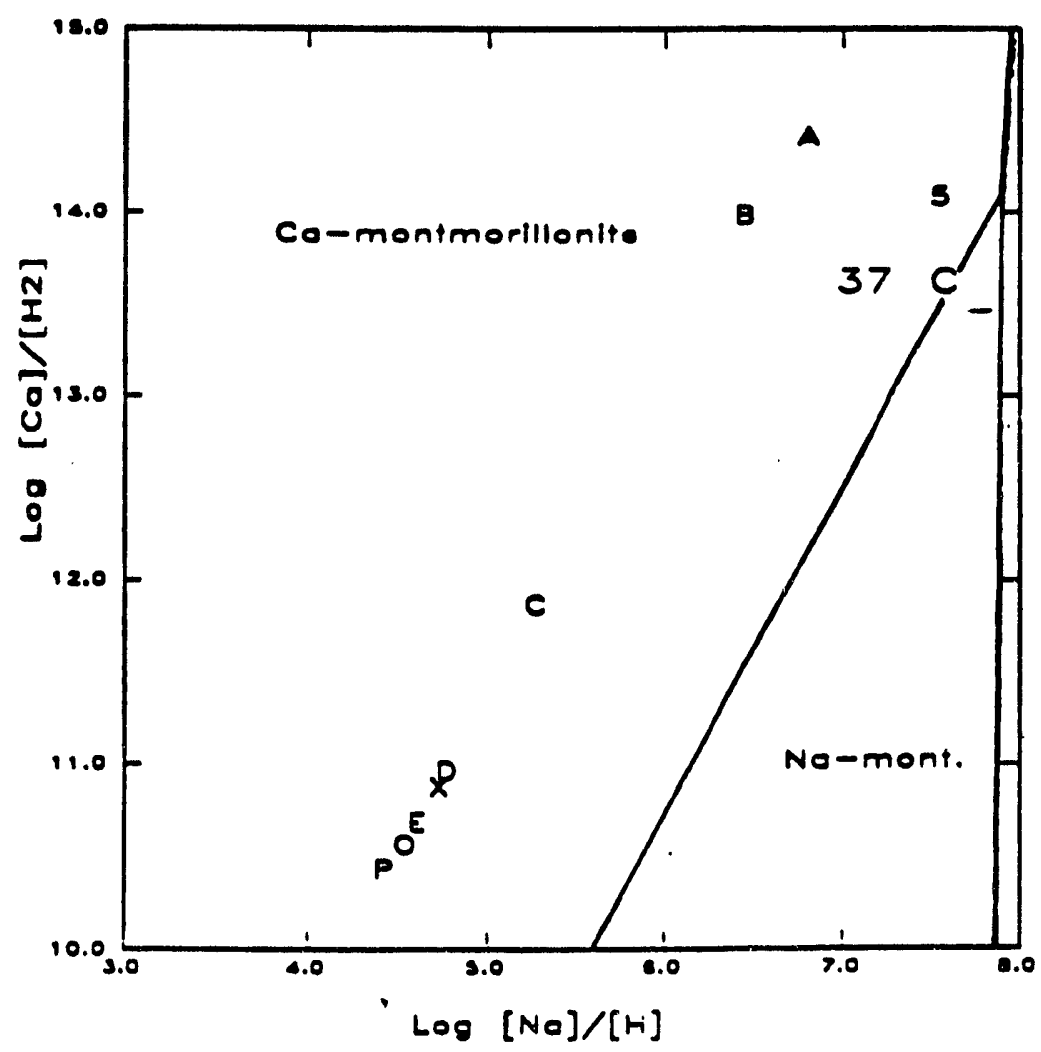

-Modeled Mixture Raflos (Port V/Carbonate)
$A=93 / 5$
$B=90 / 10$
$c=80 / 20$
$D=70 / 30$
$E=60 / 40$

Figure 19: Calcium-sodium mineral stability relationships of flow path model compared to Yucca Mountain, Nevada, wells at 1 bar pressure and $25^{\circ} \mathrm{C}$ and $37^{\circ} \mathrm{C}$. Part $\Gamma$ (symbol 4) plots off scale at $\log \mathrm{Ca} / \mathrm{H}^{2}=22.2$ and $\log$ $\mathrm{Na} / \mathrm{H}=5.17$. 


\section{TABLE 7}

ANALYSES OF WATER TABIE WELLS ON YUCCA MOU:TAIN, NEVADA

USW WT-7 USW WT-10 UE25 WT-12 UE25 WT-14 UE25 WT-15

\begin{tabular}{|l|c|c|c|c|c|}
\hline \hline $\mathrm{pH}$ & & & & 7.6 & 7.5 \\
$\mathrm{~T}\left({ }^{\circ} \mathrm{C}\right)$ & 8.7 & 8.4 & 34 & 31 & 28 \\
(mclality) & 34 & 40 & & & \\
$\mathrm{Ca}$ & $6.5 \times 10^{-5}$ & $6.8 \times 10^{-5}$ & $3.5 \times 10^{-7}$ & $3.5 \times 10^{-1}$ & $2.9 \times 10^{-4}$ \\
$\mathrm{Mg}$ & $7.4 \times 10^{-6}$ & $2.9 \times 10^{-6}$ & $1.6 \times 10^{-6}$ & $3.2 \times 10^{-5}$ & $7.0 \times 10^{-6}$ \\
$\mathrm{Na}$ & $4.2 \times 10^{-3}$ & $4.1 \times 10^{-3}$ & $2.8 \times 10^{-3}$ & $1.8 \times 10^{-3}$ & $2.9 \times 10^{-3}$ \\
$\mathrm{~K}$ & $5.3 \times 10^{-5}$ & $2.9 \times 10^{-5}$ & $5.9 \times 10^{-5}$ & $1.4 \times 10^{-1}$ & $1.2 \times 10^{-4}$ \\
& & & & & \\
$\mathrm{Log} \mathrm{P}_{\mathrm{CO}_{2}}$ & -3.27 & -3.01 & -2.31 & -2.18 & -2.08 \\
SI calcite & 0.15 & -0.13 & -0.31 & -0.77 & -0.41 \\
SI quartz & 0.35 & 0.66 & 0.39 & 0.89 & 0.89 \\
SI Na mont. & -0.46 & 3.15 & 1.78 & 4.32 & 4.19 \\
SI analcime & -3.30 & -1.78 & -3.41 & -2.58 & -2.38 \\
\hline
\end{tabular}

\section{TABLE 8}

COMPARISON OF YUCCA MOUNTAIN WELL ANALYSES TO PHREEQE FLOW PATH MODEL: HYDR.OCHEMICAL

\section{PART V ANALYSIS}

Part $\mathrm{V}$ USW H-3 USW H-3* USW H-1 USW H-4 UE-25 b"1

\begin{tabular}{|c|c|c|c|c|c|c|}
\hline $\begin{array}{l}\mathrm{pH} \\
\mathrm{T}\left({ }^{\circ} \mathrm{C}\right) \\
\text { (molality) } \\
\mathrm{Ca} \\
\mathrm{Mg} \\
\mathrm{Na} \\
\mathrm{K}\end{array}$ & $\begin{array}{c}9.5 \\
40 \\
1.5 \times 10^{-5} \\
8.0 \times 10^{-8} \\
3.4 \times 10^{-5} \\
1.4 \times 10^{-6}\end{array}$ & $\begin{array}{c}9.2 \\
26 \\
1.9 \times 10^{-6} \\
- \\
5.2 \times 10^{-3} \\
2.8 \times 10^{-6}\end{array}$ & $\begin{array}{c}7.1 \\
45 \\
7.9 \times 10^{-1} \\
5.1 \times 10^{-1} \\
4.4 \times 10^{-3} \\
1.1 \times 10^{-1}\end{array}$ & $\begin{array}{c}7.7 \\
33 \\
1.1 \times 10^{-1} \\
4.1 \times 10^{-6} \\
6.6 \times 10^{-3} \\
1.7 \times 10^{-6}\end{array}$ & $\begin{array}{c}7.4 \\
35 \\
4.2 \times 10^{-1} \\
1.2 \times 10^{-5} \\
3.2 \times 10^{-3} \\
6.6 \times 10^{-6}\end{array}$ & $\begin{array}{c}7.1 \\
37 \\
4.5 \times 10^{-1} \\
2.9 \times 10^{-6} \\
2.0 \times 10^{-3} \\
7.2 \times 10^{-6}\end{array}$ \\
\hline $\begin{array}{l}\mathrm{Log} \mathrm{P}_{\mathrm{CO}_{2}} \\
\text { SI calcite } \\
\text { SI quartz } \\
\text { SI Na mont. } \\
\text { SI analcime }\end{array}$ & $\begin{array}{r}-4.60 \\
-0.14 \\
0.43 \\
1.49 \\
-1.67\end{array}$ & $\begin{array}{r}-3.85 \\
-0.08 \\
0.75 \\
1.50 \\
-1.94\end{array}$ & $\begin{array}{r}-1.49 \\
-0.19 \\
0.61 \\
6.32 \\
-1.48\end{array}$ & $\begin{array}{r}-0.89 \\
-2.59 \\
0.77 \\
4.08 \\
-1.89\end{array}$ & $\begin{array}{r}-2.10 \\
-0.42 \\
0.74 \\
4.25 \\
-2.32\end{array}$ & $\begin{array}{r}-1.87 \\
-0.73 \\
0.75 \\
4.65 \\
-2.52\end{array}$ \\
\hline
\end{tabular}

* Modeled USW H-3 as suggested in BALANCE: $51 \%$ Part V and $49 \%$ carbonate aquifer.

Yucca Mountain well data from Benson and Mchinley, 1985. 
mineral suites were interacting. Further modifications on these zones would be necessary to overcome these problems. The solution modeled in Part V appears most similar to wells with high $\mathrm{pH}$, and is most similar in terms of molality to Yucca Mountain well analyses than are the other zones. Therefore, the solution modeled in Part $\mathrm{V}$ is used as the representative solution of tuffaceous water when mixing carbonate water with the tuffaceous water. 


\section{MIXING MODELED VOLCANIC AND CARBONATE WATERS}

After the geochemical evolution of the water along the hypothetical flow path through the tuffaceous aquifer has been established, the resultant solution is computationally mixed with water from the 1297 to 1805 -meter interval of well UE-25 $\mathrm{p}^{\#} 1$, which is assumed to be representative of water from the Paleozoic carbonate aquifer in the Yucca Mountain area. This is to determine if the Yucca Mountain wells could be a mixture of tuffaceous and carbonate waters. The mixing problem is approached through two methods: 1) modeling specific Yucca Mountain wells using both BALANCE and PHREEQE; and 2) a general comparison of all Yucca Mountain wells to solutions modeled in PHREEQE from the mixing of the hypothetical tuffaceous water together with the carbonate aquifer water in set ratios.

\section{Modeling Specific Wells}

Ten Yucca Mountain wells were chosen for more intensive studies to determine the possibility of mixing between the carbonate and tuffaceous aquifers.

To find approximate mixing ratios between the hypothetical volcanic water and the carbonate water needed to produce a solution similar to an actual well on Yučca Mountain, the waters are first mixed using the computer program BALANCE. In this program, a sample analysis from a Yucca Mountain well is entered along with the analyses of carbonate water, a solution from one of the modeled zones and a mineral suite which is expected to be present. From these 
analyses, BALANCE suggests a mixing ratio between the carbonate and modeled volcanic water necessary to produce the given well sample analysis and saturation indices of the minerals present. During this BALANCE modeling, a potential problem arose which affected the outcome of the BALANCE model. Because several different mineral phases could be used as sources or sinks for ions, the specific mineral suite used made a great difference in the final mixing ratio between the two input waters. When the mineral suite used is similar to the diagenetic minerals present around the screened interval of the well, the resultant mixed solution is similar to the well sample. However, when the specified mineral suite used was composed of minerals found in a different zone than that near the screened interval, BALANCE would suggest a mixing ratio that did not match the actual well sample. Therefore, care had to be taken during the literature review of the published well logs to determine the minerals most likely to be present.

Because BALANCE runs through a mass balance of molalities, and thus might suggest solutions which are thermodynamically impossible, the modeled volcanic zone solution and carbonate water are next mixed together using PHREEQE. Using the ratios suggested by BALANCE, the hypothetical tuffaceous and carbonate aquifer waters are titrated together and the resulting solution solved by PHREEQE for mineral equilibria and molality. The actual sample from the well is also solved in PHREEQE for mineral equilibria, and compared to the results of the mixing model.

\section{Modeling Specific Wells Results}

The Yucca Mountain wells listed below were chosen for individual modeling attempts. They are the water table (WT) wells sampled during this study, and the wells in which previous studies have indicated an upward flow gradient. 


\begin{tabular}{|c|c|c|c|}
\hline$U E-25 p^{\# 1}$ & $\mathrm{UE}-25 \mathrm{~b}^{\# 1} 1$ & USW WT-10 & UE-25 WT-15 \\
\hline USW H-3 & USW $\mathrm{H}-4$ & UE-25 WT-12 & \\
\hline ISW H-1 & USW WT-7 & UE-25 WT-14 & \\
\hline
\end{tabular}

\section{Results from Well UE-25 $p \# 1$}

For the first modeling effort, the well UE-25 $p^{\#} 1$ was chosen because the upward gradient in this well has been documented hydrologically and geochemically by previous authors (Craig and Robison, 1984). To find the approximate mixing ratios between the carbonate aquifer and hypothetical tuffaceous waters, volcanic aquifer and carbonate aquifer sample analyses from well UE-25 $\mathrm{p}^{\# 1}$ (Benson and McKinley, 1985) were entered into a BALANCE program along with the analysis of Part $\mathrm{V}$ water, and a mineral suite consisting of albite, adularia, illite, quartz and calcite. Through a mass balance of these analyses, BALANCE suggested that the volcanic water sample from UE-25 $\mathrm{p}^{\#} 1$ was a mixture of $68 \% \mathrm{Part} \mathrm{V}$ water and $32 \%$ water from the carbonate aquifer. This agrees fairly closely to the $28.6 \%$ carbonate water influence suggested by Craig and Robison (1984, p.49) from a borehole flow study.

The next step was to mix the hypothetical tuffaceous water and the carbonate aquifer water to determine if the ratio suggested in BALANCE was thermodynamically correct with respect to the actual volcanic water sample from UE-25 $\mathrm{p}^{\# 1}$. The two water types were titrated together using PHREEQE, and the resulting solution, $68 \% \mathrm{Part} \mathrm{V}$ and $32 \%$ carbonate aquifer water, solved for mineral equilibria. This modeled mixed solution was compared to the volcanic sample from UE-25 $\mathrm{p}^{\#} 1$, and the results given in Table 9.

The modeled UE-25 $\mathrm{p}^{\# 1}$ volcanic water and the actual UE-25 $\mathrm{p}^{\# 1}$ volcanic waters were similar in $\mathrm{pH}, \mathrm{P}_{\mathrm{CO}_{2}}$, molalities of their elements and saturation indices. The waters were both supersaturated with respect to montmorillonites, heulandite and illite, and undersaturated with respect to 


\begin{tabular}{|c|c|c|c|c|c|}
\hline $\mathrm{CO}$ & $\begin{array}{l}\text { RISON O } \\
\text { M FLOW }\end{array}$ & $\begin{array}{l}\text { TAB } \\
\text { Q-25 p"1 SA } \\
\text { TH MLIIN }\end{array}$ & $\begin{array}{l}9 \\
\text { PLE ANA } \\
\text { MODEL U }\end{array}$ & $\begin{array}{l}\text { SIS TO UE- } \\
\text { NG PHREEG }\end{array}$ & \\
\hline Mineral & $\begin{array}{r}\text { UE-25 } \mathrm{p}^{\#} 1 \\
\text { (modeled) } \\
\text { Log Satu }\end{array}$ & $\begin{array}{l}\text { UE-25 } p^{\# 1} \\
\text { (sampled) }^{2} \\
\text { on Index }\end{array}$ & Element & $\begin{array}{r}\mathrm{UE}-25 \mathrm{p}^{\# 1} 1 \\
(\text { modeled })^{1} \\
\mathrm{Mo}\end{array}$ & $\begin{array}{l}\mathrm{UE}-25 \mathrm{p}^{\#_{1}} \\
\text { (sampled) } \\
\text { ity }\end{array}$ \\
\hline calcite & -0.191 & -0.381 & $\mathrm{pH}$ & 7.1 & 6.8 \\
\hline $\log \mathrm{P}_{\mathrm{CO}_{2}}$ & -1.490 & -1.218 & $\mathrm{~T}^{\circ} \mathrm{C}$ & 45.1 & 44.3 \\
\hline chalcedony & 0.202 & 0.229 & $\mathrm{Ca}$ & $7.99 \times 10^{-4}$ & $9.23 \times 10^{-1}$ \\
\hline cristobalite & 0.325 & 0.353 & $\mathrm{Mg}$ & $5.11 \times 10^{-1}$ & $4.12 \times 10^{-1}$ \\
\hline quartz & 0.611 & 0.640 & $\mathrm{Na}$ & $4.37 \times 10^{-3}$ & $4.00 \times 10^{-3}$ \\
\hline chlorite & 0.322 & -5.114 & $\mathrm{~K}$ & $1.07 \times 10^{-4}$ & $1.43 \times 10^{-1}$ \\
\hline illite & 4.293 & 1.563 & $\mathrm{Fe}$ & $5.66 \times 10^{-0}$ & $1.74 \times 10^{-0}$ \\
\hline Na-mont. & 6.322 & 3.703 & $\mathrm{Al}$ & $2.24 \times 10^{-5}$ & - \\
\hline $\mathrm{K}$-mont. & 6.307 & 3.745 & $\mathrm{Si}$ & $7.83 \times 10^{-4}$ & $8.16 \times 10^{-4}$ \\
\hline Ca-mont. & 5.300 & 2.707 & $\mathrm{Cl}$ & $3.47 \times 10^{-1}$ & $3.67 \times 10^{-1}$ \\
\hline analcime & -1.458 & -2.846 & $\mathrm{C}$ & $5.11 \times 10^{-3}$ & $4.62 \times 10^{-3}$ \\
\hline heulandite & 11.906 & 9.379 & $\mathrm{~S}$ & $5.42 \times 10^{-1}$ & $3.96 \times 10^{-4}$ \\
\hline adularia & 1.108 & -0.072 & $F$ & $7.87 \times 10^{-6}$ & $1.79 \times 10^{-6}$ \\
\hline albite & 0.379 & -0.976 & $\mathrm{Li}$ & $2.71 \times 10^{-5}$ & $3.31 \times 10^{-6}$ \\
\hline
\end{tabular}

${ }^{1} \mathrm{UE}-25 \mathrm{p}^{*} 1$ modeled: $68 \%$ Part $\mathrm{V}$ solution and $32 \%$ carbonate aquifer water.

${ }^{2} \mathrm{UE}-25 \mathrm{p}^{\# 1}$ sample: From Benson and McKinley, 1985. 
analcime, calcite and $\mathrm{CO}_{2}$. There was a difference between the two analyses in the saturation indices of chlorite and the feldspars, which was probably a function of $\mathrm{Mg}^{2+}$ concentration, and the manner in which the minerals were equilibrated in PHREEQE. When plotted on mineral stability diagrams (Figures 18 and 19), the modeled volcanic UE-25 $\mathrm{p}^{\#} 1(\mathrm{X})$ plotted very close to the actual UE-25 $\mathrm{p}^{\# 1}$ volcanic sample (P). Therefore, this modeled volcanic UE-25 $\mathrm{p}^{\# 1}$ solution may be considered fairly representative of processes occurring in the well $\mathrm{UE}-25 \mathrm{p}^{\#} 1$.

\section{Results From Wells USW H-3 and USW H-4}

The next modeling attempts were with two other wells in which temperature and isotopic data have indicated upward flow gradients. The anomalously enriched $\delta^{13} \mathrm{C}$ values of $-4.9 \%$ (Benson and McKinley, 1985) from well USW H-3 indicated the possibility of upward flow from the carbonate aquifer. The problem in BALANCE of using the correct mineral suite, discussed previously, appeared in this model. When the mineral suite was from diagenetic mineral Zone IV, (feldspars, illite, quartz and calcite), the suggested ratio of Part $\mathrm{V}$ to carbonate water necessary to produce the USW H-3 water sample was 51 . $\%$ to $49 \%$, respectively. However, when this ratio was mixed using PHREEQE, the resulting solution was very dissimilar to the USW H-3 sample (Table 8). In Figures 18 and 19 it may be seen that the $\log$ activity ratios of the $51 / 49$ mixture flow model $(\mathrm{O})$ lies far from the log activity of USW H-3 (H). In both Figures, the actual data from USW H-3 has greater log activities of $\mathrm{Na}^{+}, \mathrm{K}^{+}$ and $\mathrm{Ca}^{2+}$ than the $51 / 49$ mix model did. As stated previously, in terms of $\mathrm{pH}$, molalities and saturation indices of mineral phases, USW H-3 more resembled the Part V solution. 
Well USW $\mathrm{H}-4$, when modeled in BALANCE with a suite of minerals from Lone $\mathrm{IV}$, indicated a possibility of being $3.4 \%$ water from the carbonate aquifer, and $96.6 \%$ from modeled Part V. However, when this mixture was equilibrated with PHREEQE, the $\mathrm{pH}$, molalities and SI of the minerals did not match those for the USW H-4 well water sample. The low percentage of carbonate water is within the range of standard deviation error of the BALANCE computations, and may not actually show a carbonate water component.

\section{Mixing Tuffaceous and Carbonate Waters in Set Ratios}

The next approach to the mixing problem is to titrate a set percentage of carbonate aquifer water into the hypothetical tuffaceous water from one of the modeled zones, using PHREEQE, and solve the resulting solution for mineral equilibria and solution composition.

The geochemical solution modeled in Part V, was chosen as being most representative of ground water found in a tuffaceous environment. This water is mixed with carbonate aquifer water from well UE-25 $\mathrm{p}^{\# 1}$ in the following ratios: $100-0 ; 95-5 ; 90-10 ; 80-20 ; 70-30$; and $60-40$ percent modeled tuffaceous to percent carbonate water, respectively.

The results from these mixtures were compared to the Yucca Mountain wells through comparison of molalities and saturation indices calculated by PHREEQE (Tables 7, 8, and 10). In addition, the log activity of major cations were plotted on mineral stability diagrams using WQPLOT for graphical comparisons in Figures 18 and 19. 


\section{TABLE 10}

PHREEQE ANALYSES OF MIXING PART V TUFFACEOUS SOLU'TION WITH CARBONATE AQUIFER WATER

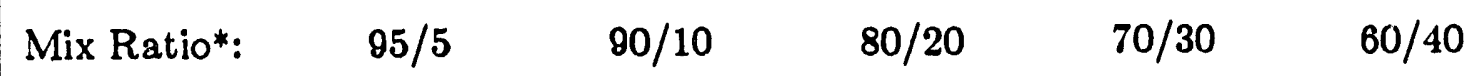

\begin{tabular}{|l|c|c|c|c|c|}
\hline \hline $\mathrm{pH}$ & 9.2 & 8.8 & 7.6 & 7.1 & 6.9 \\
$\mathrm{~T}\left({ }^{\circ} \mathrm{C}\right)$ & 40 & 41 & 43 & 45 & 46 \\
(molality) & & & & & \\
$\mathrm{Ca}$ & $1.4 \times 10^{-4}$ & $2.6 \times 10^{-4}$ & $5.1 \times 10^{-4}$ & $7.5 \times 10^{-4}$ & $1.0 \times 10^{-3}$ \\
$\mathrm{Mg}$ & $8.0 \times 10^{-5}$ & $1.6 \times 10^{-4}$ & $3.2 \times 10^{-4}$ & $4.8 \times 10^{-4}$ & $6.4 \times 10^{-4}$ \\
$\mathrm{Na}$ & $3.6 \times 10^{-3}$ & $3.8 \times 10^{-3}$ & $4.0 \times 10^{-3}$ & $4.3 \times 10^{-3}$ & $4.6 \times 10^{-3}$ \\
$\mathrm{~K}$ & $2.8 \times 10^{-5}$ & $4.3 \times 10^{-5}$ & $7.2 \times 10^{-5}$ & $1.0 \times 10^{-4}$ & $1.3 \times 10^{-4}$ \\
& & & & & \\
$\mathrm{Log} \mathrm{P}_{\mathrm{CO}_{2}}$ & -4.08 & -3.57 & -2.17 & -1.55 & -1.28 \\
SI calcite & 0.71 & 0.79 & 0.09 & -0.18 & -0.18 \\
SI quartz & 0.53 & 0.60 & 0.64 & 0.61 & 0.59 \\
SI Na mont. & 2.42 & 3.27 & 5.61 & 6.30 & 6.25 \\
SI analcime & -1.46 & -1.35 & -1.32 & -1.43 & -1.58 \\
& & & & & \\
\hline
\end{tabular}

* Mixing Ratio: Part V/Carbonate

\section{Mixing In Set Ratio Results}

The remaining Yucca Mountain wells which were compared to the theoretical flow path and mixing model were generally near-neutral $\mathrm{pH}$ wells. In this respect they did not resemble the higher $\mathrm{pH}$ modeled Part V water (Tables 7 and 8$)$. However, when comparing the models of mixed carbonate/tuffaceous waters to these Yucca Mountain wells, there was a similarity (A-E, Figures 18 and 19), especially with the mixing ratios from $80 / 20$ to $60 / 40$ (C,D,E). This would seem to indicate either:

1) a great volume of upward flow from the carbonate aquifer into the volcanic tuffs; 
or that

2) the geochemical model is not representative of the all the volcanic wells on Yucca Mountain, thus giving erroneous results. This is an inheirent problem of taking a relatively complex system such as that found at Yucca Mountain and over-simplifying it in the geochemical model.

Based upon the literature, the WATEQDR analyses discussed previously, and isotope analyses in the next section, it is believed that the similarity of volcanic/carbonate water mixtures to the Yucca Mountain well analyses is due to the initial Part $\mathrm{V}$ water not being representative of all the wells completed in volcanic terrain on Yucca Mountain. When these mixing models were analyzed for element molalities and saturation index of calcite, it was seen that they were higher in calcium and magnesium than the actual well samples, and supersaturated with calcite (Table 10), which was not likely to occur in the Yucca Mountain wells. Based upon the WATEQDR results, which show definite differences in montmorillonite saturation with increasing $\mathrm{P}_{\mathrm{CO}_{2}}$ between carbonate and volcanic wells (Figure 15 ), and $\delta^{13} \mathrm{C}$ isotope analyses in the following section, (p. 91 and Figure 22) which indicate no marine carbonate influence, it appears unlikely that large volumes of carbonate-type ground water are entering the tuffaceous zones. The mixed zones may resemble the Yucca Mountain wells, especially those with nearly neutral $\mathrm{pH}$, because the initial Part $\mathrm{V}$ solution may have too high a $\mathrm{pH}$ to accurately represent the ground water in the volcanic rocks. The solution from $\mathrm{Part} \mathrm{V}$ does appear to model higher $\mathrm{pH}$ wells, such as USW H-3 and USW WT-10. Therefore, rather than assume that the wells are greatly influenced by the carbonate aquifer, it would be desirable to further refine the modeled flow path through the tuffaceous aquifer to represent lower pH wells. 


\section{ENVIRONMENTAL ISOTOPES}

Environmental isotopes are a means of fingerprinting and tracing waters in the hydrologic cycle. Some of their uses include determining the origin (location, age, recharge process) and history (mixing, discharge process) of the water. The environmental isotopes collected in this study were the isotopes of oxygen, hydrogen and carbon.

Environmental isotope values are expressed in $\delta$ as units "per mil" $(\%)$ units. The $\delta$ value is a ratio of the isotope value to the international Standard Mean Ocean Water (SMOW) and is found by the formula:

$$
\delta=\left(\frac{\mathrm{R}_{\mathrm{x}}-\mathrm{R}_{\text {std }}}{\mathrm{R}_{\mathrm{std}}}\right) \times 10^{3}
$$

where $\mathrm{R}_{\mathrm{x}}=$ isotope ratios of heavy over light;

and $\mathrm{R}_{\text {std }}=$ corresponding ratio in the standard (SMOW)

(Fritz and Fontes, 1980).

\section{Deuterium and ${ }^{18}$ Oxygen}

The three stable isotopes of oxygen $\left({ }^{16} \mathrm{O},{ }^{17} \mathrm{O},{ }^{18} \mathrm{O}\right)$ were discovered in 1929 by Giaugue and Johnson (Gat, 1980); ${ }^{18} \mathrm{O}$ makes up $0.1 \%$ of these (Fritz and Fontes, 1980). Deuterium (D), a stable isotope of hydrogen, was discovered by Urey in 1932 (Gat, 1980) and composes just $0.015 \%$ of the hydrogen isotopes $\left({ }^{1} \mathrm{H}, \mathrm{D},{ }^{3} \mathrm{H}\right)$ (Fritz and Fontes, 1980$)$.

The initial source of water vapor is the ocean, where $\delta^{18} \mathrm{O}$ and $\delta \mathrm{D}$ values are, by definition, $0.0 \%$. As the water vapor is transported away from the 
ocean source, the $\delta$ value of the isotopes is controlled by fractionation, a temperature dependent process whereby either lighter or heavier isotopes are selectively removed from a liquid or vapor. This process occurs through equilibrium fractionation (Rayleigh distillation), and nonequilibrium fractionation through molecular kinetic processes (the 'raindrop effect') during phase changes such as evaporation and condensation.

Once below the evaporation zone, recharging ground waters generally do not undergo phase changes. Therefore, oxygen and hydrogen isotopes do not experience further fractionation and may be considered to be conservative in the flow system. Exceptions to this may occur during diagenetic mineral formation or within limestone aquifers where exchange with calcite may cause a shift towards heavier $\delta^{18} \mathrm{O}$ values (Clayton et al., 1966). During alteration of volcanic rocks to smectites, feldspars and zeolites, mineral precipitation may remove the heavier isotopes of oxygen, causing a slight depletion of $\delta^{18} \mathrm{O}$ values (Lawrence and Taylor, 1971; Lawrence et al., 1979). A significant $\delta^{18} \mathrm{O}$ depletion requires very slow ground-water movement and a low water/rock ratio (Drever, 1982), a condition which is not found in most aquifers. However, due to the thick unsaturated zone present at Yucca Mountain, very slow matrix flow may provide these conditions. Because of a lack of data on this subject at Yucca Mountain, the quality of conservativeness of the isotopes was assumed. It is a combination of this conservativeness and the relative scarceness of these isotopes that makes them so useful as ground-water tracers.

Previous authors have discussed the deuterium and oxygen isotopic compositions of the waters surrounding Yucca Mountain. Claassen (1985) found the $\delta \mathrm{D}$ and $\delta^{18} \mathrm{O}$ values of Amargosa Desert grourd water to be depleted compared to Yucca Mountain; this he attributed to colder climate conditions 
during recharge 10,000 to 15,000 years B.P. Using environmental isotopes, White and Chuma (1987) concluded that Oasis Valley ground water is a mixture of underflow from Pahute Mesa and recharge in the nearby Bullfrog Hills.

Ingraham et al. (1989) studied five years of precipitation and spring $\delta^{18} \mathrm{O}$ and $\delta \mathrm{D}$ data from the NTS and suggested that the local meteoric water line was $\delta \mathrm{D}=6.87 \delta^{18} \mathrm{O}-6.5$, which was slightly $\delta^{18} \mathrm{O}$ enriched from the Craig (1961) global meteoric water line. From this study, they suggested that White Rock and Cane Springs, two NTS springs which issue from perched water in volcanic rock, had recharge travel paths of less than one year. Summer recharge from high intensity thundershowers was hypothesized to be the fastest recharge, occurring along fractures. Winter precipitation was thought to contribute a larger, more steady recharge by both fracture and matrix flow. An enrichment of $\delta^{18} \mathrm{O}$ isotopes in the spring samples was thought to have been caused through fractionation brought about by evaporation.

In Figure 20, the $\delta^{18} \mathrm{O}$ and $\delta \mathrm{D}$ analyses from the water table (WT) wells sampled for this study are plotted along with Yucca Mountain samples (McKinley and Benson, 1985). Kerrisk (1987) and Matuska (1989) found that Yucca Mountain well waters (except for USW H-3) were slightly $\delta$ D depleted from the proposed local meteoric water line (Ingraham et al., 1989), and the Craig (1961) global meteoric water line, which is indicative of closed basins (Drever, 1982). Kerrisk also found that water samples in Forty Mile Wash (J-12, $J-13, U E-29 a^{\# 2}$ ) were slightly more enriched in terms of $\delta^{18} O$ and $\delta D$, which he proposed were waters originating as precipitation at higher temperatures or lower elevations. Most of the Forty Mile Wash wells lie on or very near to the proposed local meteoric water line (Ingraham et al., 1989), and at a more enriched position than the other Yucca Mountain wells, which might suggest relatively recent recharge which has undergone evaporation, similar to the 


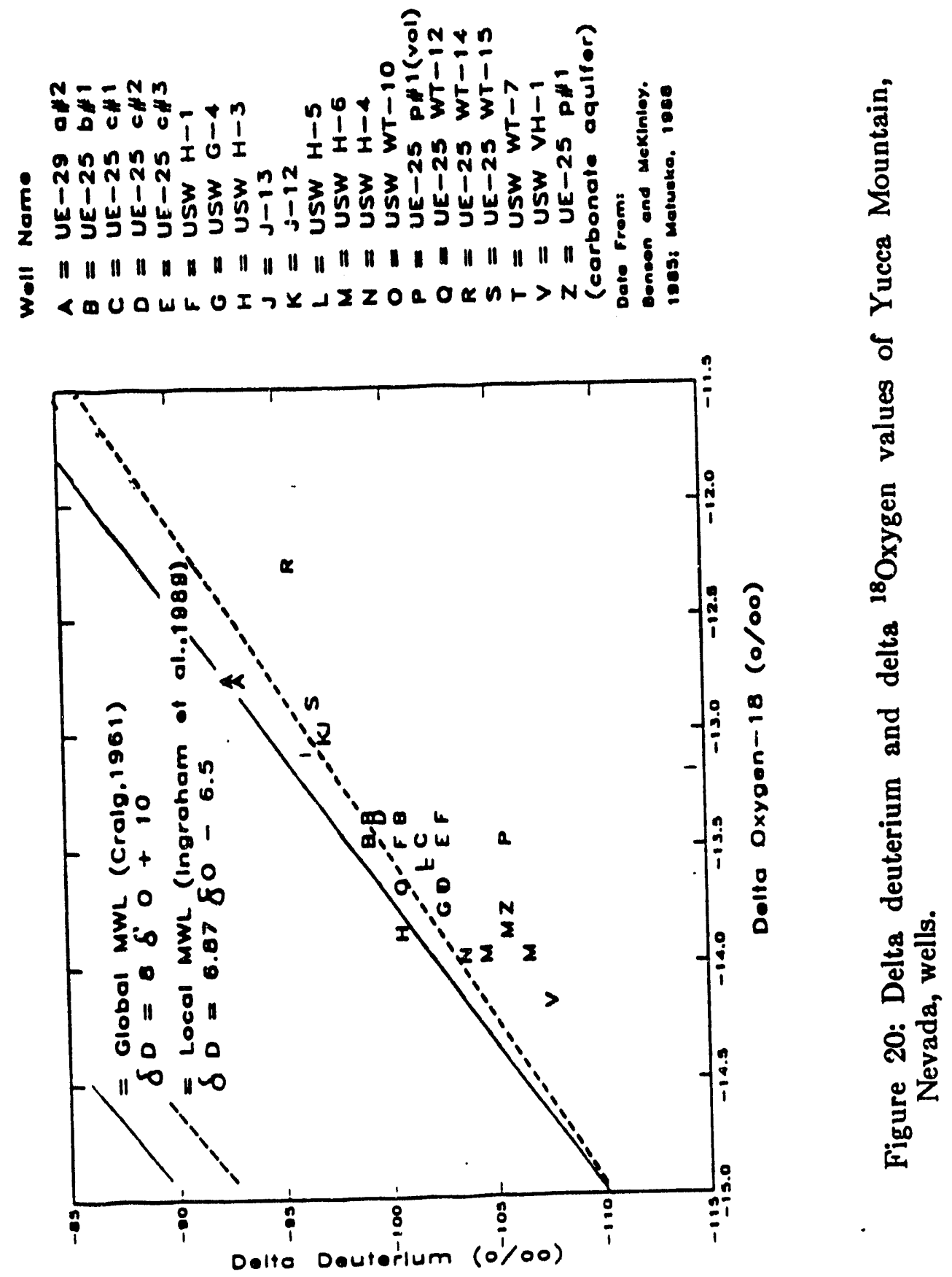



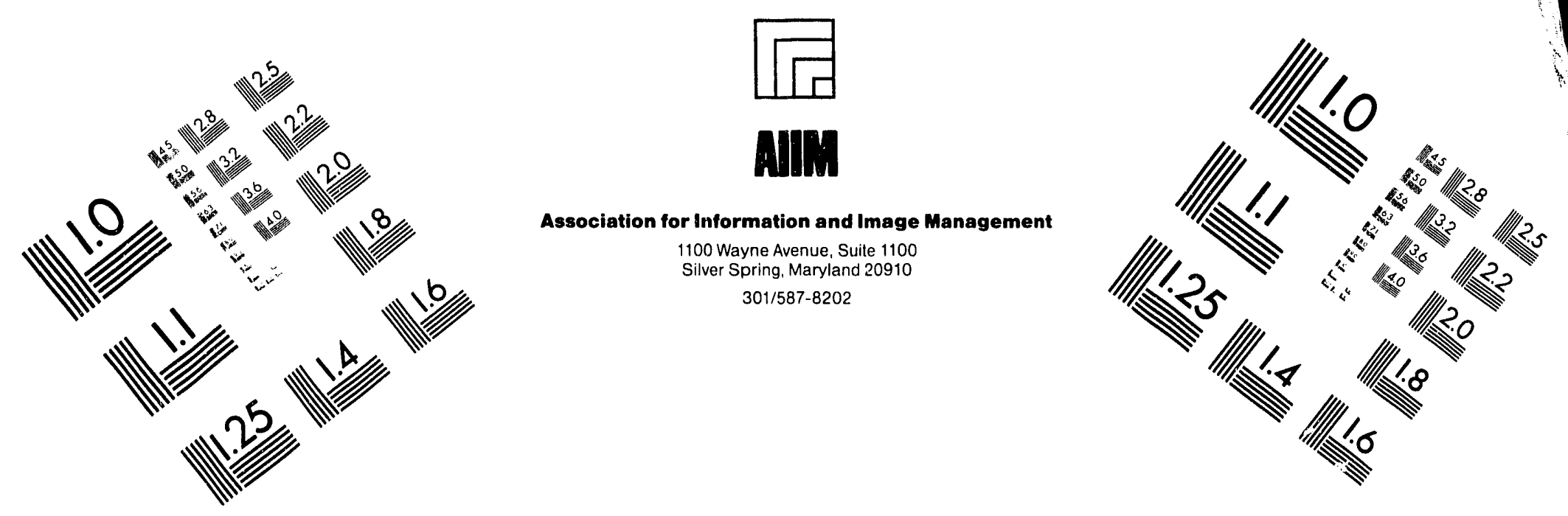

\section{Centimeter}

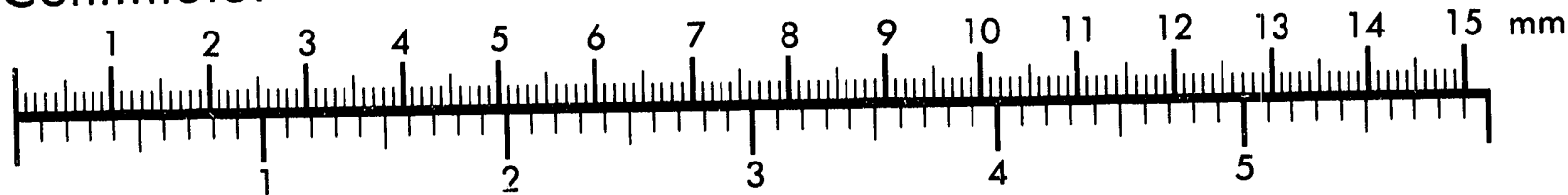
Inches
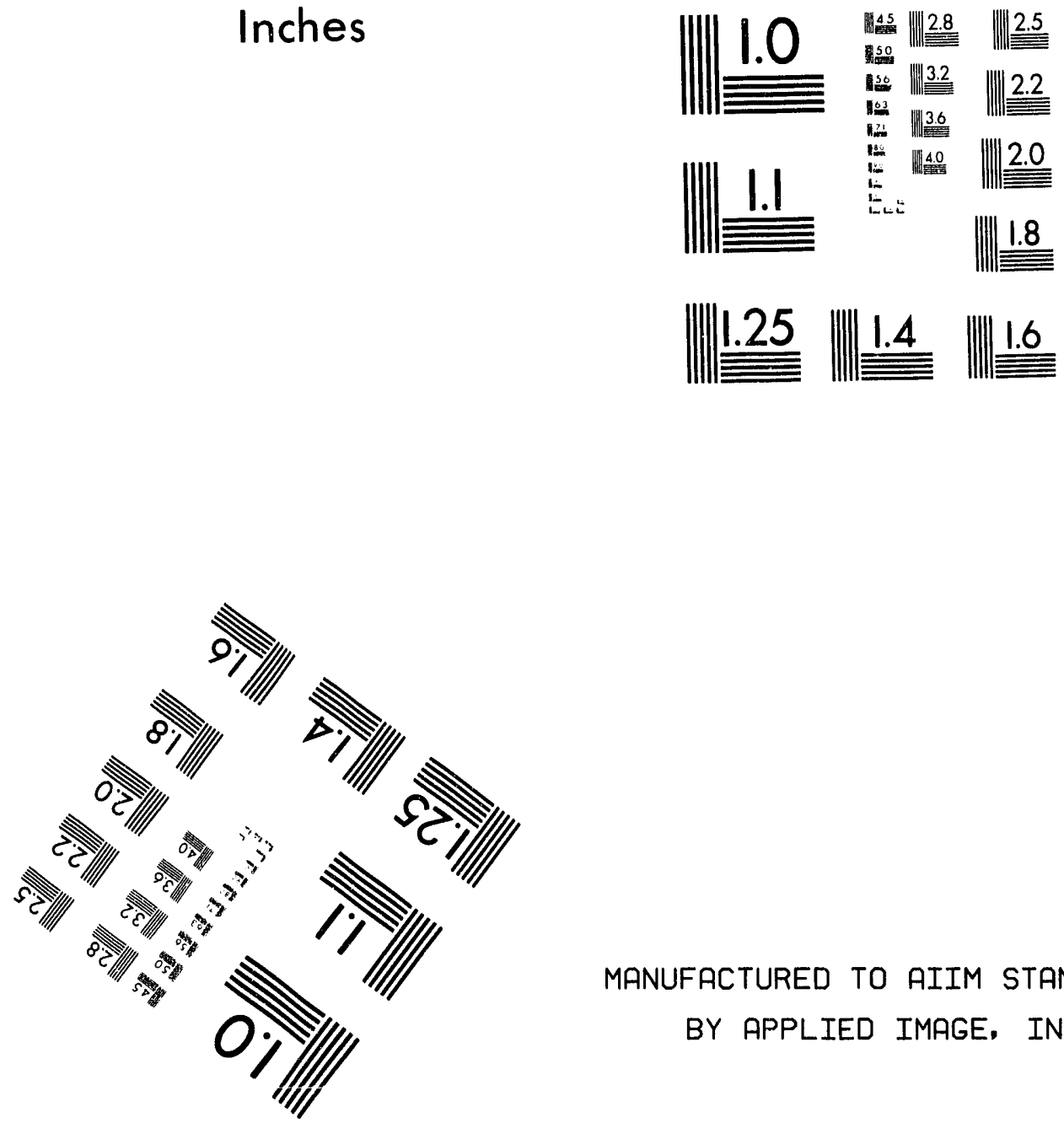

MANUFACTURED TO AIIM STANDARDS

BY APPLIED IMAGE, INC.

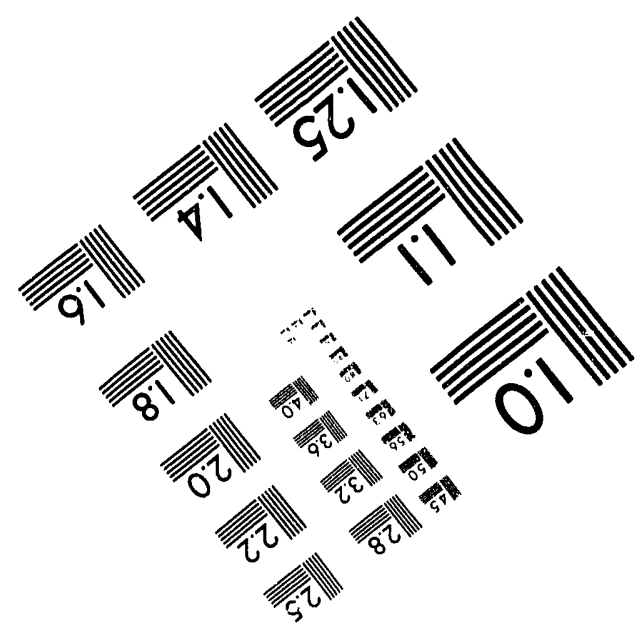



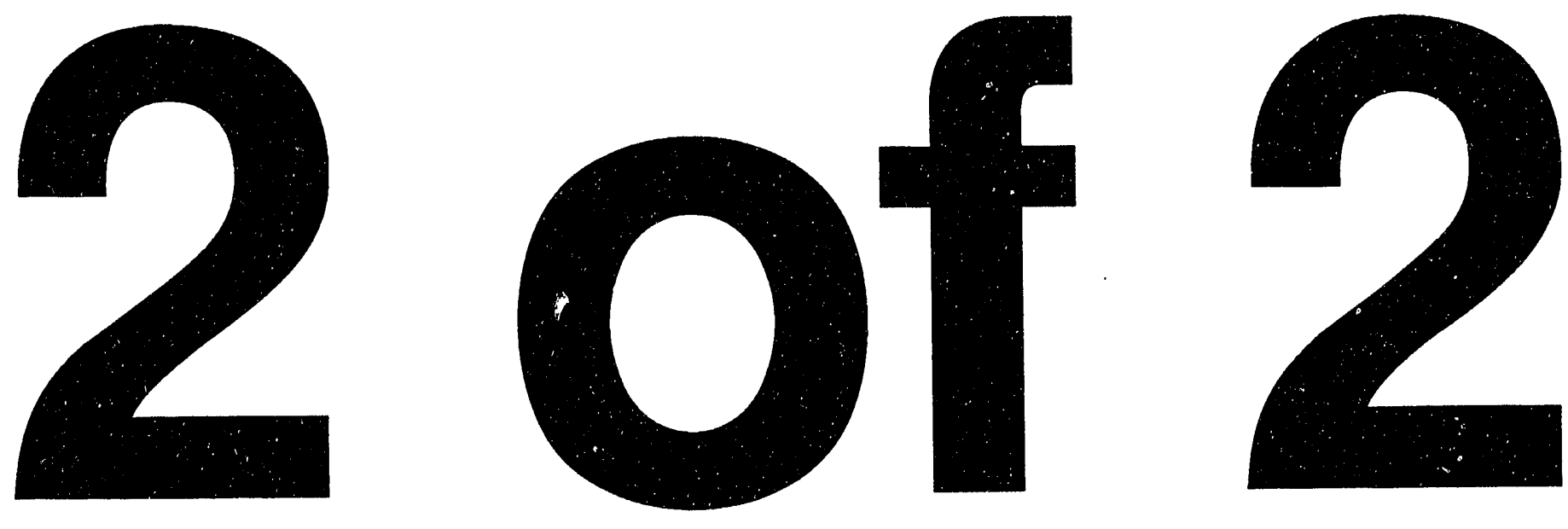
scenario they proposed for White Rock and Cane Springs.

Water table wells UE-25 WT-14 and UE-25 WT-15, located a few kilometers to the west of Forty Mile Wash, show isotopic signatures similar to Forty Mile Wash wells. UE-25 WT-15 appears almost identical in terms of $\delta^{18} \mathrm{O}$ and $\delta \mathrm{D}$, to $\mathrm{J}-12$ and $\mathrm{J}-13$, while UE-25 WT-14 shows an even greater $\delta^{18} \mathrm{O}$ enrichment. Wells UE-25 $b^{\# 1}$ and USW H-3 also show slight enrichment, suggesting different recharge sources than the other Yucca Mountain wells. The isotope enrichment may be due to $\delta^{18} \mathrm{O}$ and $\delta \mathrm{D}$ shifts in precipitation, as Kerrisk suggests, or evaporation, as Ingraham et al. suggest, or perhaps the isotopic signature of the ground water is being affected through exchange with $\mathrm{CaCO}_{3}$ of the caliche layers as suggested by Clayton et al. (1966). During the length of time required for $\mathrm{CaCO}_{3}$ exchange to significantly change $\delta^{18} \mathrm{O}$, it appears the soil water would be removed through evapotranspiration rather than recharging the ground water. Another possibility is water is recharged quickly to the subsurface along fractures, as suggested by Waddell et al. (1984), and encounters calcite coatings on the fracture walls or caliche layers in the thick vadose zone.

\section{Carbon Isotopes}

The stable carbon isotope, ${ }^{13} \mathrm{C}$, is useful in ground-water studies as an indicator of the path of the carbon cycle. Carbon-13 makes up about $1.11 \%$ of carbon isotopes, and the varying $\delta^{13} \mathrm{C}$ values reflect changes $\mathrm{CO}_{2}$ undergoes along the flow path. Each $\mathrm{CO}_{2}$ source has a distinctive $\delta^{13} \mathrm{C}$ value, from vegetation $\delta^{13} \mathrm{C}$ being most depleted, to marine limestone $\delta^{13} \mathrm{C}$ being most enriched (Table 11). Sources of $\delta^{13} \mathrm{C}$ in ground water are (Salomons and Mook, 1980; Drever, 1982): 
TABLE 11

$\delta^{13} \mathrm{C}$ SIGNATURES OF $\mathrm{CO}_{2}$ SOURCES

$\mathrm{CO}_{2}$ Source $^{1}$

$\delta^{13} \mathrm{C}(\%)$

Carbonate Rock

-2 to +2

Caliche $^{2}$

-7.9 to -4.6

Atmosphere $\mathrm{CO}_{2}$

-9 to -7

Soil Water ${ }^{3}$

-13.1 to -11.1

CAM vegetation ${ }^{4}$

-25 to -14

${ }^{1} \delta^{13} \mathrm{C}$ values from Fritz and Fontes, 1980.

${ }^{2}$ Nevada Test Site caliche values from Boughton, 1986.

3 Oasis Valley soil water from White and Chuma, 1987.

${ }^{4}$ Crassulaceae Acid Metabolism vegetation; i.e., drought resistant plants, see note 1.

1) introduction of $\mathrm{CO}_{2}$ gas from the atmosphere ( $\delta^{13} \mathrm{C}$ light).

2) dissolution of carbonates by action of $\mathrm{CO}_{2}\left(\delta^{13} \mathrm{C}\right.$ heavy);

3) dissolution of organic matter $\left(\delta^{13} \mathrm{C}\right.$ light $)$;

4) weathering of silicate minerals $\left(\delta^{13} \mathrm{C}\right.$ light $)$;

Carbon-14, the radioactive isotope of carbon, has a half-life of 5,730 years and is used in age-dating ground waters. Percent modern carbon (PMC) is a measure of the ${ }^{14} \mathrm{C}$ content expressed as a percentage of the standard ${ }^{14} \mathrm{C}$ from an 1390 wood grown in an environment free of fossil fuel $\mathrm{CO}_{2}$ (Fritz and Fontes, 1980) and can be used to determine apparent relative ages of ground waters. Carbon, which is in equilibrium with the atmosphere, will have PMC values of $100 \%$ (or greater, due to contamination by atomic testing); carbon, which is 
isolated from the atmosphere for long periods of time, will have PMC values near zero (Fritz and Fontes, 1980).

Recently recharged ground water will have relatively depleted $\delta^{13} \mathrm{C}$ values due to the input from the atmosphere, soil water, vegetation and caliche. Correspondingly, the PMC of these waters should be high. Water that has had contact with a limestone formation will show enrichment of $\delta^{13} \mathrm{C}$ values along a flow path, and may have either high or low values of PMC, depending upon the length of the flow path. Water from the regional carbonate aquifer underlying the Yucca Mountain study area should generally show enriched $\delta^{13} \mathrm{C}$ values and very low PMC.

Figures 21 and 22 show the relationship of PMC to $\delta^{13} \mathrm{C}$ values for the study area and Yucca Mountain, repectively. In Figure 21, Pahute Mesa (P) wells (Boughton, 1986; White and Chuma, 1987) show low values of PMC combined with very light $\delta^{13} \mathrm{C}$ values, similar to CAM vegetation values. This could indicate either mixing of older ground water with more recent recharge, or simply be a ground water that has been removed from the atmosphere for a long time. There is no isotopic evidence for influence from carbonate aquifer waters at Pahute Mesa.

Oasis Valley (O) ground waters (White and Chuma, 1987) show a wide range of PMC values, from less than $10 \%$ to fully modern, and $\delta^{13} \mathrm{C}$ are values very close to atmospheric. This indicates a system open to $\mathrm{CO}_{2}$ exchange with the atmosphere, in which older ground waters are mixing with more recent recharge. Based upon ${ }^{13} \mathrm{C}$ values, Amargosa Desert (A) ground waters (Claassen, 1985) are probably open to atmospheric $\mathrm{CO}_{2}$, however, they generally appear to be older (PMC < 30\%) than the Oasis Valley waters. Both Oasis Valley and Amargosa Desert waters show a trend of increasing $\delta^{13} \mathrm{C}$ with decreasing PMC, indicating the influence of older water, most likely from the 


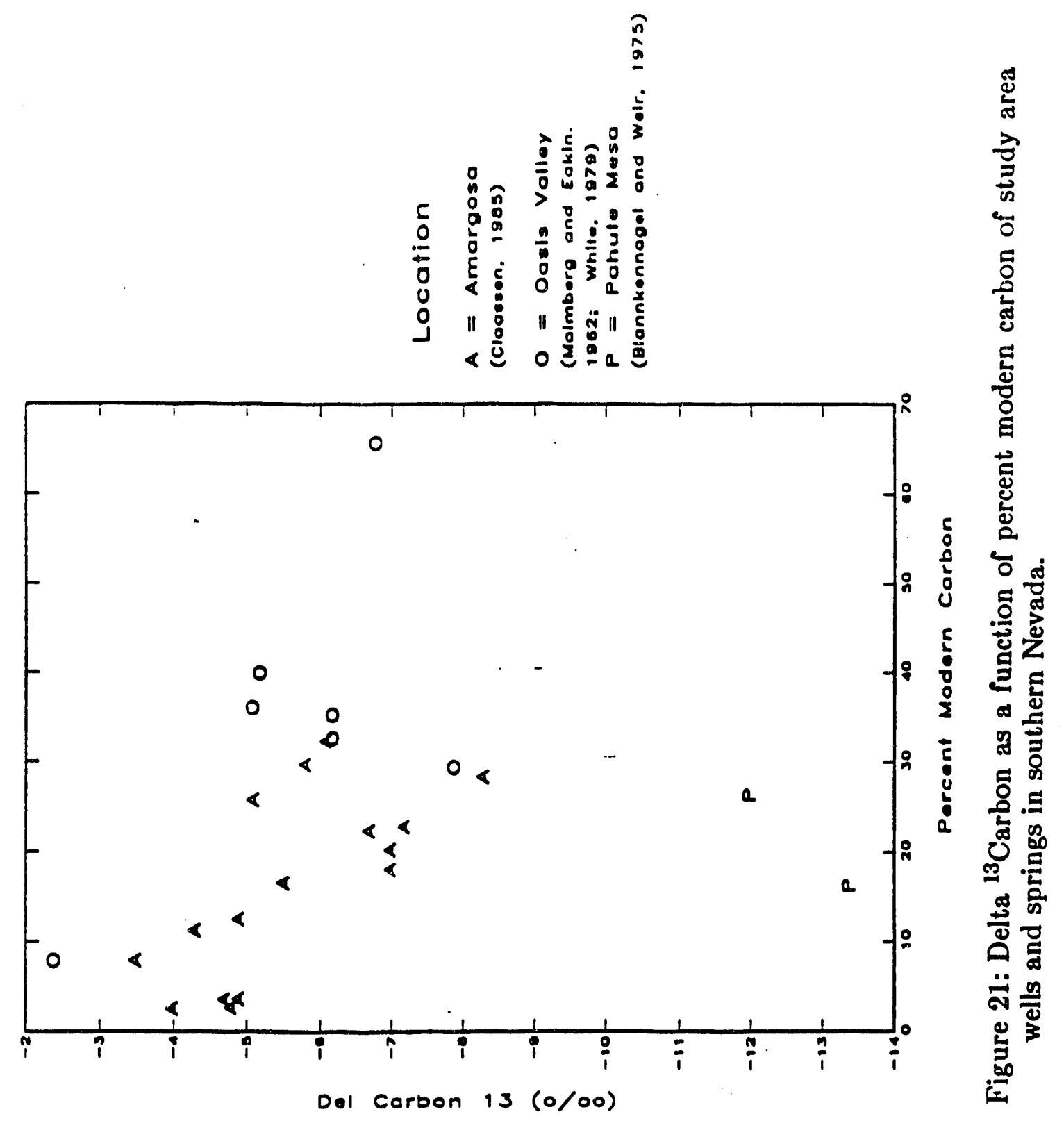


regional carbonate aquifer.

In Figure 22, the Yucca Mountain wells (Benson and McKinley, 1985) show two trends in PMC relationships: a flow path with high PMC, present in Forty Mile Wash; and a flow path with lower PMC, found in the other Yucca Mountain wells. Wells in Forty Mile Wash (J-12, J-13, UE-29 $\mathrm{a}^{\#} 2$ ) have higher PMC values and depleted $\delta^{13} \mathrm{C}$, which correlates well with $\delta^{18} \mathrm{O}$ and $\delta \mathrm{D}$ data which indicated a more recent recharge (Kerrisk, 1987). However, wells UE-25 WT-14 and UE-25 WT-15, which were similar in $\delta^{18} \mathrm{O}$ and $\delta \mathrm{D}$ to J-12, $\mathrm{J}-13$ and UE-29 $\mathrm{a}^{\#} 2$, show much lower PMC values, which indicates an older ground water than in Forty Mile Wash.

Along a flow path based upon hydraulic gradients (Robison, 1984), there is a general trend for increasing $\delta^{13} \mathrm{C}$ with decreasing PMC. This could be due to mixing of older waters with more recent recharge. USW H-6, which is upgradient of the majority of the Yucca Mountain wells shows a low PMC value and $\delta^{13} \mathrm{C}$ values close to atmospheric values. This could indicate mixing between older water and more recent waters, perhaps along the Solitario Canyon fault. The relatively depleted $\delta^{13} \mathrm{C}$ values of wells $\mathrm{UE}-25 \mathrm{WT}-14, \mathrm{UE}-25 \mathrm{WT}-15$, USW $H-1$ and, to a lesser extent, UE-25 $b^{\#} 1$ and USW H-5, which place the data outside the general trend of the flow path, fall within the $\delta^{13} \mathrm{C}$ range of soil water and CAM vegetation given in Table 11. Of these five wells, three are proximate to major faults: UE-25 $b^{\#} 1$ and USW H-1 along Drill Hole Wash fault; and UE-25 WT-14 near Paintbrush Canyon Fault (Figure 2). This indicates that these faults may be conduits for recharge, which agrees with Waddell et al. (1984) suggestion of pulse recharge through open fractures. This also agrees with the $\delta^{18} \mathrm{O}$ and $\delta \mathrm{D}$ analyses.

Three samples (USW H-3, UE-25 $\mathrm{p}^{\# 1} 1$ volcanic and carbonate), show $\delta^{13} \mathrm{C}$ signatures similar to carbonate waters $\left(\delta^{13} \mathrm{C}\right.$ near $\left.-2^{\circ} / \infty\right)$. An upward gradient 


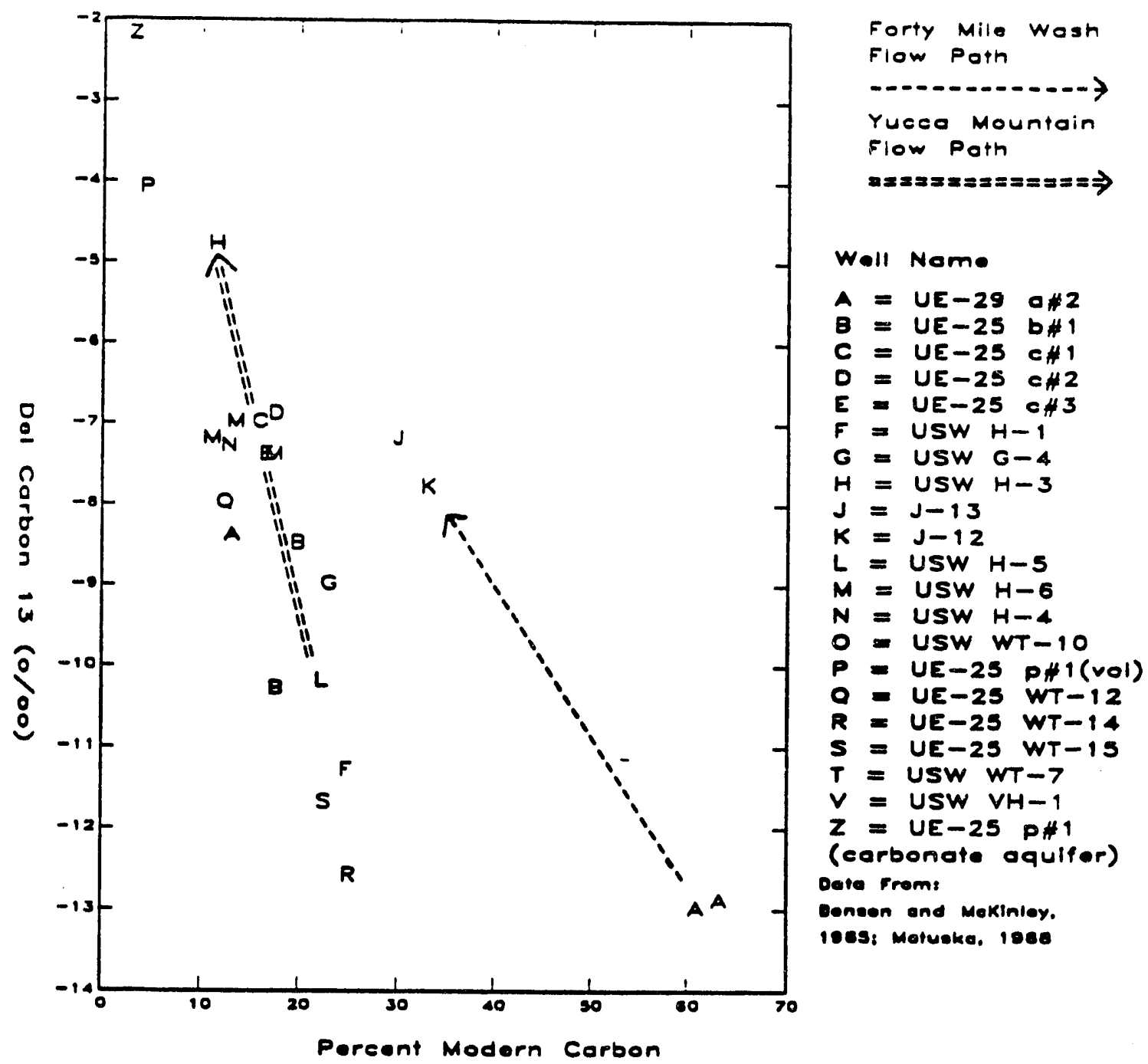

Figure 22: Delta ${ }^{13}$ Carbon as a function of percent modern carbon of Yucca Mountain, Nevada, wells. Flow paths from potentiometric data of Robison, 1985. 
from the carbonate aquifer to the tuffaceous aquifers has been documented hydrologically in well UE-25 $\mathrm{p}^{\#} 1$, therefore enriched $\delta^{13} \mathrm{C}$ values might be expected. However, USW H-3, a well completed in the tuffs on the crest of Yucca Mountain, is anomalously enriched compared to the other Yucca Mountain wells. From these data it may appear that there is some influence of carbonate ground water in this well. However, geochemical analysis of this well, discussed in the previous geochemical modeling sections, shows no influence from the carbonate aquifer. This anomalous $\delta^{13} \mathrm{C}$ value could be caused by more recent recharge waters, perhaps along fractures, which have passed through an enriched $\delta^{13} \mathrm{C}$ caliche zone. In studies of caliche zones in soil on the NTS, Boughton (1986) found that waters had heavier $\delta^{13} \mathrm{C}$ than the soil-gas samples, indicating the influence of another factor such as caliche. In addition, well USW H-3 has $\delta^{18} \mathrm{O}$ and $\delta \mathrm{D}$ values which are very similar to modern precipitation (Figure 20), a further indication of more recent recharge. 


\section{SUMMARY AND CONCLUSIONS}

The purpose of this study was to further define the possibility of upward flow from the regional carbonate aquifer into the overlying Tertiary volcanic tuff aquifer, using a variety of isotopes and geochemical modeling techniques.

\section{Conclusions From WATEQDR Analysis}

Initial computer modeling of the study area wells was conducted using WATEQDR to construct mineral stability diagrams of $\mathrm{Na}-\mathrm{K}$ and $\mathrm{Ca}-\mathrm{Na}$ minerals at $25^{\circ} \mathrm{C}$ and $37^{\circ} \mathrm{C}$. Data from the wells lie within smectite stability fields at lower temperatures, while those at higher temperatures lie within the K-feldspar fields. A flow path from Pahute Mesa to Oasis Valley to Amargosa Desert, as first suggested by Winograd and Thordarson (1975), shows an increase of $\mathrm{K}$-montmorillonite, $\mathrm{K}$-feldspar and $\mathrm{Ca}$-montmorillonite precipitation along the flow pat?. This could be caused by either the thermodynamics of the system being most conducive for $\mathrm{K}^{+}$and $\mathrm{Ca}^{2+}$ ion exchange within the montmorillonites, or an increase in $\mathrm{Ca}^{2+}$ to the system through weathering of carbonate detritus or inflow from a carbonate aquifer. For the area of Oasis Valley and Amargosa Desert, both of these are likely to be factors in controlling the dominance of $\mathrm{K}$ and $\mathrm{Ca}$ minerals.

Yucca Mountain well chemistries appear to be supersaturated with respect to montmorillonites, illites, feldspars and quartz polymorphs, and undersaturated with respect to analcime, based on mineral stability cliagrams. 
There is a tendency for $\mathrm{Ca}^{2+}$ and $\mathrm{K}^{+}$mineral stability to increase along a flow path. Wells in Forty Mile Wash are less evolved with respect to feldspar development than are Yucca Mountain wells. This suggests that Forty Mile Wash may be acting as a local recharge area. The resulting dominance of $\mathrm{Na}^{+}$ in solution is probably from the selective removal of $\mathrm{K}^{+}$and $\mathrm{Ca}^{2+}$ by mineral precipitation. This agrees with White et al. (1980) findings for Rainier Mesa.

\section{Conclusions From PHREEQE Model}

\section{Summary of Results}

A hypothetical flow path through a tuffaceous aquifer was modeled using PHREEQE, based upon formation lithologies presented in previous literature. The geochemical model was divided into five parts based upon diagenetic mineral zones, and water/rock interactions within each zone were controlled by reactions with diagenetic smectite, zeolites and feldspars. Part V, the final reaction zone, appears to be the most analogous in terms of $\mathrm{pH}$, molality, log activity of ions and saturation indices of minerals, to a high $\mathrm{pH}$ tuffaceuos water.

The flow system, except for Part I, was modeled as one which is closed to $\mathrm{CO}_{2}$ input from the atmosphere for two reasons: studies by White and Chuma (1987) suggested that deep ground-water systems were closed, and, in addition, when this system is modeled with $\mathrm{P}_{\mathrm{CO}_{2}}$ at equilibrium, the $\mathrm{pH}$ of the water quickly decreased to less than 4.00; and, the partial pressure of $\mathrm{CO}_{2}$ generally decreases from Part I to Part V, indicating that the system is closed, rather than open, as Kerrisk (1987) suggests.

When these modeled zones were compared to Yucca Mountain well samples, the solution of Part V was most similar to tuffaceous waters with high $\mathrm{pH}$, such as USW H-3, or USW WT-10. Wells displaying water with lower $\mathrm{pH}$ did not 
appear to be well represented by this flow model.

The attempts to model well UE-25 $\mathrm{p}^{\# 1} 1$ were successful; BALANCE models predicted a mixture of $68 \%$ volcanic water (from Part V) to $32 \%$ carbonate aquifer water. When these ratios were mixed using PHREEQE, the resultant solution was similar to the volcanic water analysis from well UE-25 $\mathrm{p}^{\# 1}$. These ratios also corresponded well with mixing values of $28.6 \%$ carbonate water reported by Craig and Robison (1984).

Similar attempts were made to model waters from other Yucca Mountain wells, with less success. Because water from most of these wells has lower $\mathrm{pH}$ than the tuffaceous water modeled in Part V, they superfically resemble mixtures of volcanic water (Part V) to carbonate water, in ratios of 80:20 through 60:40. This would indicate a great influx of carbonate waters to these wells. However, from the WATEQDR and $\delta^{13} \mathrm{C}$ analyses, this doas not appear likely. The initial resemblance may be more a factor of the Part V solution not being truly representative of lower $\mathrm{pH}$ tuffaceous waters, rather than any influence from the carbonate water.

\section{Discussion of Errors in Modeling}

Problems with geochemical modeling arise when the extremely complicated system present at Yucca Mountain is simplified.

The greatest source of error in the PHREEQE flow path model is ignoring the kinetics of the system, such as the rate and path of ground-water flow. The actual pathway of a ground water through the interlayered Tertiary volcanic aquifers and aquitards is probably tortuous, rather than the steady, smooth flow path assumed in the model. Ground-water flow is likely to be rapid through the fractured welded tuff zones, and slower through zones of bedded tuff moving as 
matrix flow. Therefore, it is likely that water samples from the fractured welded tuffs might have different chemistries than those from the bedded tuff zones, as was found in Rainier Mesa by White et al. (1980).

Time is a factor which is also ignored by PHREEQE. This may cause problems in mineral equilibrium, because PHREEQE assumes all mineral reactions go to equilibrium. There are no data to support this assumption at Yucca Mountain. The kinetics involved in reaching equilibrium are dependent upon the flow path, rate of ground-water velocity, nature of mineral surfaces and the amount of impurities within the mineral. The diagenetic minerals employed in the model may be coated with silicates, calcite, and aluminum and iron oxides; therefore, mineral precipitation, dissolution, or ion exchange may not be approaching equilibrium.

The use of end-member zeolites and smectites may also influence the results. The limitations imposed upon the model by the lack of mixed-cation thermodymanic data resulted in the model being set up with end-member minerals which are not representative of the true mineralogy that is controlling ion-exchange and mineral equilibria. A topic for further research would be to determine the thermodynamic properties of these minerals, which would allow the PHREEQE model to become more site specific.

Mixing the modeled tuffaceous zone water with the carbonate water relied on one analysis of carbonate water in the vicinity of Yucca Mountain, a sample from well UE-25 $\mathrm{p}^{\# 1}$. This may be a factor in the success in modeling the mix of Part V water with carbonate water to form the volcanic water of UE-25 $\mathrm{p}^{\# 1}$. The carbonate sample from UE-25 $\mathrm{p}^{\# 1}$ may not be representative of all the carbonate ground water beneath Yucca Mountain, which could be a cause of the misleading results of the mixed model attempts. 
Other sources of error in the model may arise from using incorrect assumptions concerning temperature, $\mathrm{Al}^{3+}$ concentrations, mineralogy and $\mathrm{P}_{\mathrm{CO}_{2}}$. Further refinements of these assumptions may improve the geochemical model.

\section{Conclusions From Isotope Analyses}

Environmental isotopes used in this study were $\delta^{18} \mathrm{O}, \delta \mathrm{D}, \delta^{13} \mathrm{C}$ and ${ }^{14} \mathrm{C}$. Yucca Mountain ground water has a deuterium depletion from the meteoric water line, which suggests recharge during conditions different than those at present. Wells in and near Forty Mile Wash are more enriched in terms of $\delta^{18} \mathrm{O}$ than the other Yucca Mountain wells and lie within or near the local meteoric water line, suggesting $\delta^{18} \mathrm{O}$ enrichment. This indicates recharge from lower elevations and/or warmer temperatures than the other Yucca Mountain wells, and that Foriy Mile Wash is acting as a local recharge zone.

Carbon isotope data show a general trend of increasing ${ }^{13} \mathrm{C}$ with increasing age of the ground water along a flow path. Two flow paths are apparent: one with high percent modern carbon in Forty Mile Wash, and a flow path(s) with low percent modern carbon indicated by Yucca Mountain WT wells. The $\delta^{13} \mathrm{C}$ data from Forty Mile Wash wells correlate well with the $\delta^{18} \mathrm{O} / \delta \mathrm{D}$ data; i.e., more recent recharge. Three wells with very depleted $\delta^{13} \mathrm{C}$ values, which are similar to $\delta^{13} \mathrm{C}$ fractionation by desert vegetation, are close to two faults in the area. This suggests that Drill Hole Wash and Paintbrush Canyon faults serve as conduits for more recent recharge in the areas near US-25 WT-14, UE-25 $b^{\#} 1$ and USW $\mathrm{H}-1$.

Two well analyses show relatively enriched $\delta^{13} \mathrm{C}$ values, indicating carbonate rock influence. In well $U E-25 \mathrm{p}^{\#} 1$, this might be expected, since an upward gradient has been previously documented; however, well USW H-3, completed in 
the tuffaceous aquifer, is anomalously enriched compared to other tuffaceous wells. Delta ${ }^{18} \mathrm{O}$ and $\delta \mathrm{D}$ data from this well indicate recharge similar to present day. The enriched $\delta^{13} \mathrm{C}$ values, therefore, may be a result of more recent recharge passing through a caliche zone, which would enrich the $\delta^{13} \mathrm{C}$, rather than any influence from the carbonate aquifer.

\section{Summary}

From the geochemical and isotopic modeling analyses of this study, the influx of ground water from the lower carbonate aquifer into the tuffaceous aquifers appears to be minimal. The upward flow gradient present in UE-25 $\mathrm{p}^{\# 1}$. may be a local phenomenon caused by a confining layer between the two aquifers. There appears to be more recent recharge to several wells which are proximal to major faults, thus supporting the pulse-recharge hypothesis. The enriched $\delta^{13} \mathrm{C}$ values from USW H-3 appear to be from caliche, rather than the tuffaceous aquifer, also suggesting more recent recharge. Forty Mile Wash appears to be a region of local recharge, extending as far as UE-25 WT-15. The geochemical model shows decreasing $\mathrm{P}_{\mathrm{CO}_{2}}$ condi-ions, suggesting that the system is closed to $\mathrm{P}_{\mathrm{CO}_{2}}$ input. The summary of the modeling attempts suggested the model was partially successful in terms of modeling high $\mathrm{pH}$ well waters and the mixed waters of UE-25 $\mathrm{p}^{\#} 1$, and was not as successful in modeling wells with near-neutral pH. Further refinement of the geochemical flow path model is desirable to increase confidence in the model of ground-water flow for Yucca Mountain. However, the results of the model may prove to be a useful start for future studies. 


\section{Additional Studies}

Additional modeling of the geochemical flow path through the tuffaceous aquifers at Yucca Mountain is currently under investigation at the Desert Research Institute, Water Resources Center, in Las Vegas. The flow path is being refined for more control over the $\mathrm{pH}$ of the solution, better ion-exchange within each zone and a more realistic value of $\log \mathrm{P}_{\mathrm{CO}_{2}}=-2.5$ in the uppermost zones. In addition, the initial input soil water was changed from the analysis of Rainier Mesa data (Henne, 1986) to an analysis of data from Shoshone Mountain (Spencer, 1989), which was thought to be more representative of the conditions found at Yucca Mountain. The preliminary results are being compared to the other carbonate aquifer wells on the NTS, in addition to Yucca Mountain well UE-25 $\mathrm{p}^{\#} 1$.

These modifications to the flow path model should help to remove many of the errors of the model as it now exists. The results of this additional work are beyond the scope of this report and will be published under a separate report. 


\section{BIBLIOGRAPHY}

Benson, L.V. and McKinley, P. W., 1985, Chemical composition of ground water in the Yucca Mountain area, Nevada, 1971-84: U.S. Geological Survey Open-File Report 85-484, 10 p.

Benson, L. V., Robison, J. H., Blankennagel, R. K., and Ogard, A. E., 1983, Chemical composition of ground water and the locations of permeable zones in the Yucca Mountain area, Nevada: U.S. Geological Survey Open-File Report 83-854, 19 p.

Bish, D. L., 1988, Smectite dehydration and stability: applications to radioactive waste isolation at Yucca Mountain, Nevada: Los Alamos National Laboratory Report LA-11023-MS, $31 \mathrm{p}$.

Bish, D. L. and Vaniman D. T., 1985, Mineralogic summary of Yucca Mountain, Nevada: Los Alamos National Laboratory Report LA-10543-MS, 56 p.

Bish, D. L., 1984, Effects of exchangeable cation composition on the thermal expansion/contraction of clinoptilolite: Clay and Clay Minerals, v. 32, n. 6, p. 444-452.

Bish, D. L., Vaniman, D. T., Byers, F. M. Jr., and Broxton, D. E., 1982, Summary of the mineralogy - petrology of tuffs of Yucca Mountain and the secondary phase thermal stability in tuffs: Los Alamos National Laboratory Report LA-9321-MS, 47 p.

Blankennagel, R. K. and Weir, J. E. Jr., 1973, Geohydrology of the eastern part of Pahute Mesa Nevada Test Site, Nye County, Nevada: U.S. Geological Survey Professional Paper 712-B, 35 p.

Bohm, B., and Jacobson, R.L., 1981, WATEQDR an updated version of WATEQF - a computerized model of natural waters [masters thesis]: University of Nevada - Reno, Desert Research Institute, 79 p.

Boughton, C.J., 1986, Integrated geochemical and hydraulic analysis of Nevada Test Site ground water system [masters thesis]: University of Nevada-Reno, 
Desel't Research Institute, 135 p.

Brown, E., Skougstad, M.W., and Fishman, M.J., 1970, Methods for collection and analysis of water samples for dissolved minerals and gases: U.S. Geological Survey Techniques of Water Resources Investigations, Book 5, Chapter A-1, 160 p.

Broxton, D.E., Bish, D. L., and Warren, R. G., 1987, Distribution and chemistry of diagenetic minerals at Yucca Mountain, Nye County, Nevada: Clays and Clay Minerals, v. 35, no. 2, p. 89-110.

Broxton, D.E., Warren, R. G., Hagan, R. C. and Luedemann, G., 1986, Chemistry of diagenetically altered tuffs at a potential nuclear waste repository, Yucca Mountain, Nye County, Nevada: Los Alamos National Laboratory Report LA-10802-MS, 160 p.

Carlos, B. A., 1985, Minerals in fractures of the unsaturated zone from drill core USW G-4, Yucca Mountain, Nye County, Nevada: Los Alamos National Laboratory Report LA-10415-MS, 55 p.

Carr, W.J., Waddell, S. J., Vick, G. S., Stock, J. M., Monsen, S. A., Harris, A. G., Cork, B. W., and Byers, F. M. Jr., 1986, Geology of drill hole UE25p\#1: a test hole into pre-Tertiary rocks near Yucca Mountain, southern Nevada: U.S. Geological Survey Open-File Report 86-175, 87 p.

Carr, W. J., 1984, Regional structural setting of Yucca Mountain, southwestern Nevada, and Late Cenozoic rates of Tectonic activity in part of the southwestern Great Basin, Nevada and California: U.S. Geological Survey Open-File Report 84-854, 109 p.

Claassen, H.C., 1985, Sources and mechanisms of recharge for ground water in the west-central Amargosa Desert, Nevada - a geochemical interpretation: U.S. Geological Survey Professional Paper 712-F, $31 \mathrm{p}$.

Claassen, H.C. and White, A.F., 1979, Application of geochemical kinetic data to ground-water systems: a tuffaceous rock system in southern Nevada: in American Chemical Society Symposium Series 93, ed. Jenne E.A., p. 771783.

Claassen, H.C., 1973, Water quality and physical characteristics of Nevada Test Site water-supply wells: U.S. Geological Survey Report 474-158, 141 p. 
Clayton, R.N., Friedman, I., Graf, D.L., Mayeda, T.K., Meents, W.F., and Shimp, N.F., 1966, The origin of saline formation waters: I. Isotopic composition: Journal of Geophysical Research, v. 71, p. 3869-3882.

Craig, H., 1961, Isotopic variations of meteoric waters: Science, v. 133, p. 17021703.

Craig, R.W. and Robison, J.H., 1984, Geohydrology of rocks penetrated by test well UE-25p\#I: U.S. Geological Survey Water Resources Investigations Report 84-4248, $57 \mathrm{p}$.

Drever, J.I., 1982, The geochemistry of natural waters: Englewood Cliffs, New Jersey, Prentice-Hall, Inc., 388 p.

D.O.E. (U.S. Department of Energy), 1986, Environmental Assessment, Yucca Mountain Site, Nevada Research and Development Area, Nevada: DOE/RW-0073, v. 2, 902 p.

DRI (Desert Research Institute), 1988, Technical procedures for ground-water sampling and hydrogeologic data acquisition - Draft 3: Nuclear Waste Project Office DTP-03.5, Yucca Mountain Project, Reno, Nevada.

Feeney, T. M., 1987, A deuterium-calibrated groundwater flow model of western Nevada Test Site and vicinity [masters thesis]: University of Nevada-Reno, Desert Research Institute, 56 p.

French, R.H., 1988, Personal communication, Desert Research Institute, Las Vegas.

French, R. H., 1983, A preliminary analysis of precipitation in southern Nevada: Desert Research Institute Report DOE/NV/10162-10, 39 p.

French, R. H., Elzeftawy, A., Bird, J., and Elliott, B., 1984, Hydrology and water resources overview for the Nevada Nuclear Waste Storage Investigations, Nevada Test Site, Nye County, Nevada: U.S. Department of Energy Report NVO-284, 114 p., annotated bibliography, 79 p.

Fritz, P. and Fontes, J.Ch., 1980, Handbook of environmental isotope chemistry, Volume 1: New York, Elsevier Scientific Publishing Company, 545 p.

Garber, M.S. and Thordarson, W., 1962, Ground water test well C, Nevada Test Site, Nye County, Nevada: U.S. Geological Survey TEI-818, 79 p. 
Gat, J., 1980, The isotopes of hydrogen and oxygen in precipitation: in Handbook of Environmental Isotope Geochemistry, Volume I, Fritz, P. and Fontes, J.Ch, (eds), New York, Elsevier Scientific Publishing Company, pp. 21-48.

Helgeson, H.C., Delany, J.M., Nesbitt, W.H., and Bird, D.K., 1978, Summary and critique of the thermodynamic properties of rock forming minerals: American Journal of Science, 278-A, 229 p.

Helgeson, H.C., 1969, Thermodynamics of hydrothermal systems at elevated temperatures and pressures: American Journal of Science, v. 267, p. 729804.

Henne, M.S., 1982, The dissolution of Rainier Mesa volcanic tufis, and its application to the analysis of the groundwater environment [masters thesis]: University of Nevada - Reno, Desert Research Institute, 113 p.

Houghton, J. G., Sakamoto, C. M. and Gifford, R.O., 1975, Nevada weather and climate: Nevada Bureau of Mines Special Publication no. 2, 78 p.

Hurlbut, C. S. Jr., and Klein, C., 1977, Manual of Mineralogy (19 th edition): New York, John Wiley \& Sons, 532 p.

Iijima, A., 1980, Geology of natural zeolites and zeolitic rocks: in Proceedings of the Fifth International Conference on Zeolites, ed. Rees, L. V., p. 103-118.

Ingraham, N.L., Lyles, B.F., Jacobson, R.L., and Hess, J.W., 1989, Stable isotope study of precipitation and spring discharge on the Nevada Test Site (in press): Desert Research Institute, Las Vegas, Nevada, 31 pp.

Karpov, I.K., Kiselev, A.I., and Letnikov, F.A., 1976, Chemical thermodynamics in petrology and geochemistry: Akademia Nauka, Irkutsk, 385 p.

Kerrisk, -.F., 1987, Groundwater chemistry at Yucca Mountain, Nevada, and vicinity: Los Alamos National Laboratory Report LA-10929-MS, 118 p.

Kerrisk, J.F., 1983, Reaction-path calculations of groundwater chemistry and mineral formation at Rainier Mesa, Nevada: Los Alamos National Laboratory Report LA-9912-MS, 41 p.

Lawrence, J.R., Drever, J.I., Anderson, T.F. and Brueckner, H.K., 1979, Importance of alteration of volcanic materials in the sediments of Deep Sea Drilling Site 323: chemistry, ${ }^{18} \mathrm{O} /{ }^{16} \mathrm{O},{ }^{87} \mathrm{Sr} /{ }^{86} \mathrm{Sr}$ : Geochimica et 
Cosmochimica Acta, v. 43, pp. 573-588.

Lawrence, J.R. and Taylor, H.P., 1971, Deuterium and oxygen-18 correlation: clay minerals and hydroxides in Quaternary soils compared to meteoric waters: Geochimica et Cosmochimica Acta., v 35, pp. 993-1003.

Lipman, P.W., Christiansen, R.L., and O'Connor, J. T., 1066, A compositionally zoned ash-flow sheet in in southern Nevada: U.S. Geological Survey Professional Paper 524-F, $47 \mathrm{p}$.

Lyles, B.F., Jacobson, R.L. and Hess, J.W., 1987, Reconnaissance of Groundwater quality in southern Nevada: Desert Research Institute Water Resources Center 41101, 83 p.

Malmberg, G.T. and Eakin, T. E., 1962, Ground-water appraisal of Sarcobatus Flat and Oasis Valley, Nye and Esmeralda Counties, Nevada: U.S. Geological Survey Ground-Water Resources - Reconnaisance Series Report $10,39 \mathrm{p}$.

Matuska, N.A., 1988, Ground-water sampling of the NNWSI water table test wells surrounding Yucca Mountain, Nevada, NWPO-TR-010-89, Reno, Nevada, 18 p.

Miller, G. A., 1977, Appraisal of the water resources of Death Valley, California - Nevada: U.S. Geological Survey Open-File Report 77-728, 68 p.

Moncure, G. K., Surdam, R. C., and McKague, H. L., 1981, Zeolite diagenesis below Pahute Mesa, Nevada Test Site: Clay and Clay Minerals, v.29, n.5, p. 385-396.

Montazer, P., and Wilson, W.E., 1984, Conceptual hydrologic model of flow in the unsaturated zone, Yucca Mountain, Nevada: U.S. Geological Survey Water Resources Investigations Report 84-4345, 55 p.

Moore, J.E., 1961, Records of wells, test holes and springs in the Nevada Test Site and surrounding area: U.S. Geological Survey TEI-781, 21 p.

Naff, R. L., Maxey, G. B., and Kaufmann, R.F., 1974, Interbasin ground-water flow in southern Nevada: Nevada Bureau of Mines and Geology Report 20, $28 \mathrm{p}$.

Naumov, G.B., Ryzhenko, B.H., and Khodakovsky, I.L., 1974, Handbook of thermodynamic data: National Technical Information Service, U.S. 
Department of Commerce, $\mathrm{Pb}-226,722 / 7 \mathrm{GA}, 328 \mathrm{p}$.

Ogard, A.E. and Kerrisk J. F., 1984, Groundwater chemistry along flow paths between a proposed repository site and the accessible environment: Los Alamos National Laboratory Report LA-10188-MS, 48 p.

Parkhurst, D.L., Plummer, L.N., and Thorstenson, D.C., 1982, BALANCE - a con puter program for calculating mass transfer for geochemical reactions in ground water: U.S. Geological Survey Water-Resources Investigations Report 82-060, 29 p.

Parkhurst, D.L., Thorstenson, D.C., and Plummer, L.N., 1980, PHREEQE - a computer program for geochemical calculations: U.S. Geological Survey Water-Resources Investigations Paper 80-96, 21 p.

Plummer, L.N., Parkhurst, D.L. and Kosiur, D.R., 1976, MIX2: a computer program for modeling chemical reactions in natural waters: U.S. Geological Survey Water-Resources Investigations Report 75-61, 68 p.

Robie, R.A. and Waldbaum, D.R., 1968, Thermodynamic properties of minerals and related substances at $298.15^{\circ} \mathrm{K}\left(25.0^{\circ} \mathrm{C}\right)$ and one atmosphere $(1.013$ bars) pressure and at higher temperatures: U.S. Geological Survey Bulletin 1259,256 p.

Robinson, G.D., 1985, Structure of pre-Cenozoic rocks in the vicinity of Yucca Mountain, Nye County, Nevada - A potential nuclear waste disposal site: U.S. Geological Survey Bulletin 1647, 22 p.

Robinson, B.P. and Beetem, W.A., 1975, Quality of water in the aquifers of the Amargosa Desert and vicinity, Nevada: U.S. Geological Survey Report 474215,64 p.

Robison, J.H., 1984, Ground-water level data and preliminary potentiometricsurface maps, Yucca ilountain and vicinity, Nye County, Nevada: U.S. Geological Survey Water-Resources Investigations Report 84-4197, 8 p.

Rush, F. Eugene, 1970, Regional ground-water systems in the Nevada Test Site atea, Nye, Lincoln and Clark Counties, Nevada: U.S. Geological Survey Water-Resources - Reconnaissance Series Report 54, 25 p.

Salomons, W. and Mook, W.G., 1986, Isotope geochemistry of carbonates in the weathering zone: in Handbook of Environmental Isotope Geochemistry, Volume 2, Fritz, P. and Fontes, J.Ch. (eds), New York, Elsevier, pp. 239- 
270.

Schoff, S.L. and Moore, J.E., 1964, Chemistry and Movement of ground water, Nevada Test Site: U.S. Geological Survey TEI-838, 178 p.

Scott, R.B. and Bonk, Jerry, 1984, Preliminary geologic map of Yucca Mountain, Nye County, Nevada, with geologic sections: U.S. Geological Survey Open-File Report 84-494, 8 p.

Sinnock, S., 1982, Geology of the Nevada Test Site and nearby areas: Sandia National Laboratory Report SAND82-2207 57 p.

Sinton, P. O., 1987, Three-dimensional, steady state finite-difference model of the ground-water flow in the Death Valley Ground-Water Basin, NevadaCalifornia [masters thesis]: Colorado School of Mines, $143 \mathrm{p}$.

Spaulding, W. G., 1985, Vegetation and climates of the last 45,000 years in the vicinity of the Nevada Test Site, south-central Nevada: U.S. Geological Survey Professional Paper 1329, 55 p.

Thordarson, W., Garber, M.S. and Walker, G.E., 1962, Ground water Test Well D, Nevada Test Site, Nye County, Nevada: U.S. Geological Survey TEI-80,

Truesdell, A.H. and Jones, B.F., 1974, WATEQ, a computer program for calculating chemical equilibria of natural waters: Journal of Research of the U.S. Geological Survey, v. 2, n. 2, p. 233-248.

U.S. Geological Survey, 1984, A summary of geologic studies through January 1 1983, of a potential high-level radioactive waste repository site at Yucca Mountain, southern Nye County, Nevada: U.S. Geological Survey Open-File Report 84-792, 103 p.

Vaniman, D., Bish, D., Broxton, D., Byers, F., Heiken, G., Carlos, B., Semarge,E., Caporuscio, F. and Gooley, R., 1984, Variations in authigenic mineralogy and sorptive zeolite abundance at Yucca Mountain, Nevada, based on studies of drill cores USW GU-3 and G-3: Los Alamos National Laboratory Report LA-9707-MS, $71 \mathrm{p}$.

Waddell, R.K, Robison, J. H., and Blankennagel, R.K., 1984, Hydrology of Yucca Mountain and vicinity, Nevada-California investigative results through mid-1983: U.S. Geological Survey Water-Resources Investigation 84-4267, 72 p. 
Waddell, R.K., 1982, Two-dimensional, steady-state mociel of ground-water flow, Nevadá Test Site and vicinity, Neyada- California: U.S. Geological Survey Water-Resources Investigations Report 82- 4085, 72 p.

Weaver, C.S. and Hill D.T., 1979, Earthquake swarms and local crustal spreading along major strike-slip faults in California: Pure and Applied Geophysics, v. 117 , p. $51-64$.

Wells, S.G., Mcradden, L.D. and Renault, C., 1988, A geomorphic assessment of Q1laternary volcanism in the Yucca Mountain area, Nevada Test Site, southern Nevada: Geological Society of America Abstracts with Programs, v. 20 , no. 3 , p. 242

White, A.F. and Chuma, N.J., 1987, Carbon and isotope mass balance models of Oasis Valley - Fortymile Canyon groundwater basin, southern Nevada: Water Resources Research, v.23, no.4, p. 571-582.

White, A.F., 1981, Controls on isotopic compositions of groundwater in southern Nevada (abstract): EOS Trans. AGU, v. 62, p. 286.

White, A.F., Claassen, H.C., and Benson, L.V., 1980, The effect of dissolution of volcanic glass on the water chemistry in a volcanic aquifer, Rainier Mesa, Nevada: U.S. Geological Survey Water- Supply paper 1535-Q, 56 p.

White, A.F., 1979, Geochemi. ry of ground water associated with tuffaceous rocks, Oasis Valley, Nevaaa: U.S. Geological Survey Professional Paper 712-E, 25 p.

Winograd, I.J. and Pearson, F.J. Jr., 1976, Major carbon 14 anomaly in a regional carbonate aquifer: possible evidence for megascale channeling, South Central Great Basin: Water Resources Research, v. 12, no. 6, p. 1125-1143.

Winograd, I.J. and Thordarson, William, 1975, Hydrological and hydrochemical framework, south-central Great Basin, Nevada-California, with special reference to the Nevada Test Site: U.S. Geological Survey Professional Paper 712-C, 126 p.

Wood, W.W., 1976, Guidelines for collection and field analysis of ground-water samples for selected unstable constituents: U.S. Geological Survey Techniques of Water Resources Investigations, Book 1, Chapter D2, 24 p. 
Woods, T.L. and Garrels, R.M., 1987, Thermodynamic values at low temperature for natural inorganic materials, an uncritical summary: New York, Oxford University Press, 242 pp. 
APPENDLX A

DATA BASE OF WELLS AND SPRINGS SURROUNDING YUCCA MOUNTAIN

Table I: Lithology and Hydrology

Table II: Water Chemistry Analyses

Table III: Isotopic Analyses 


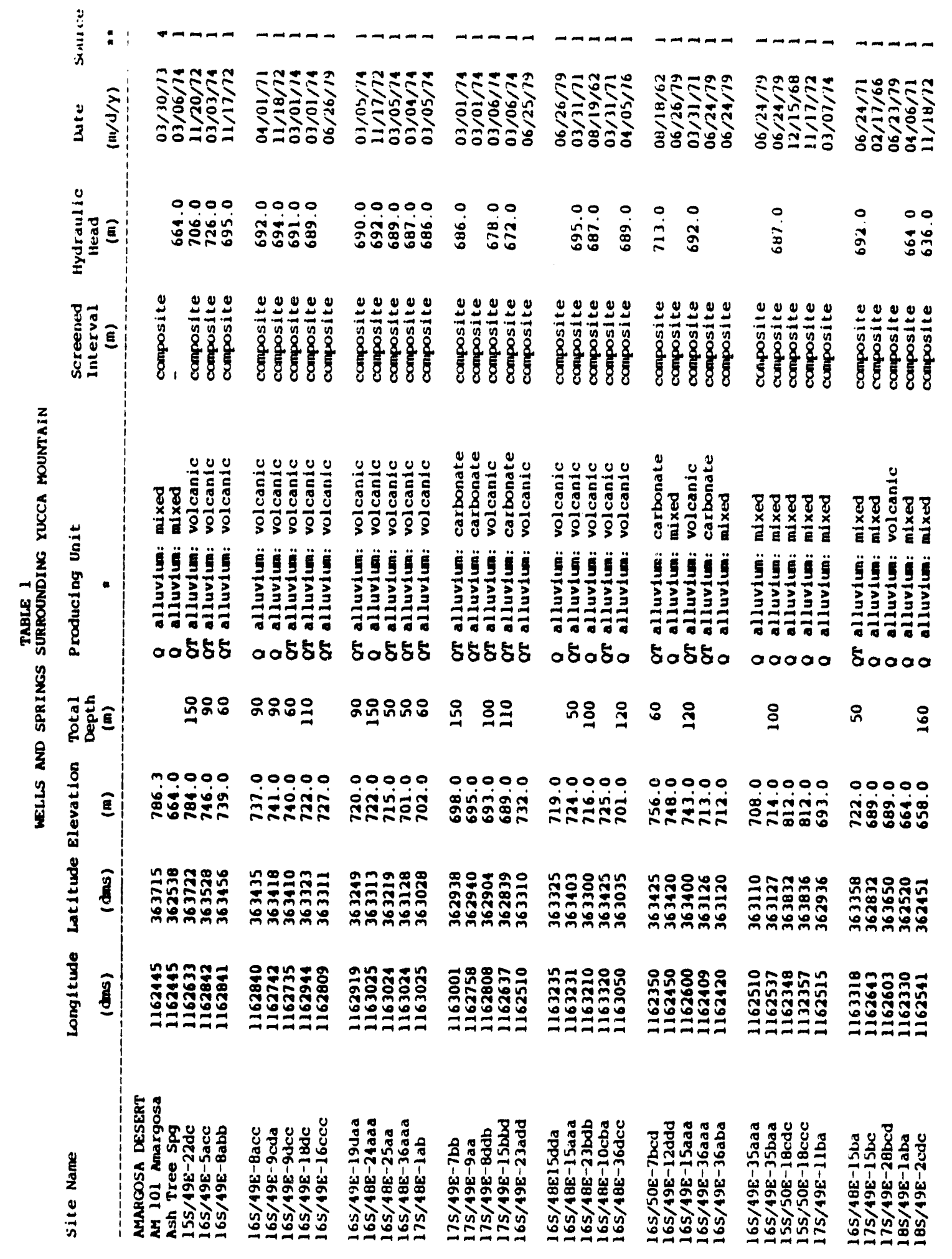




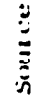

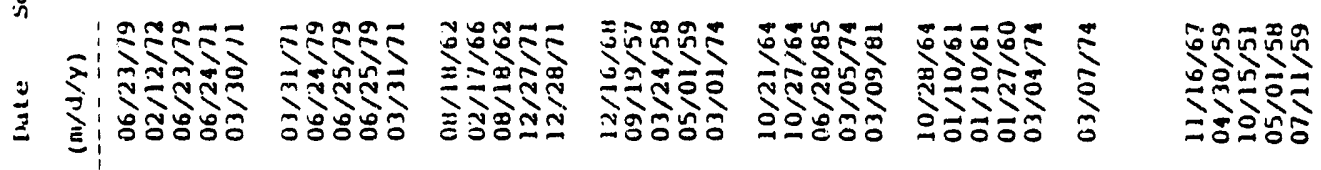

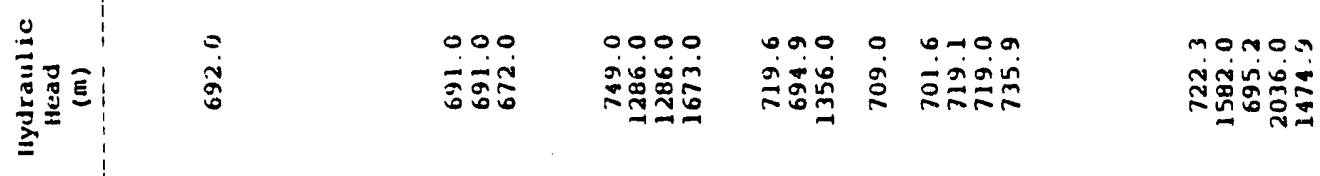

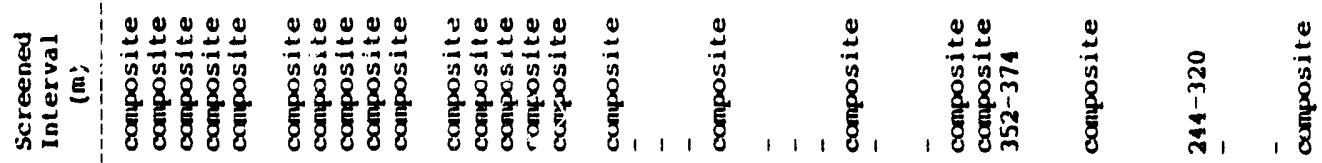

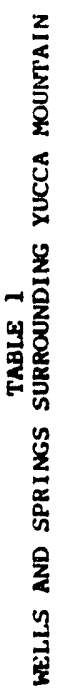

.

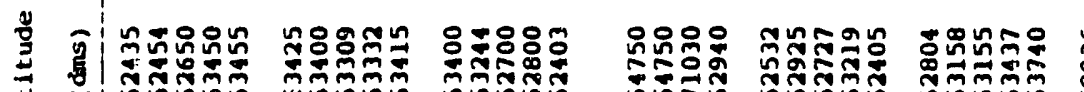

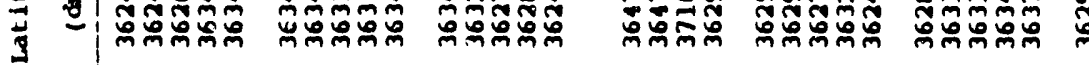

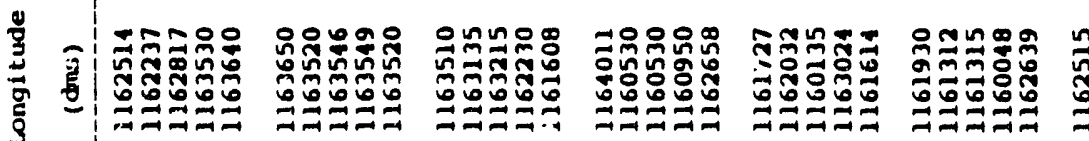

$\cong$ 品

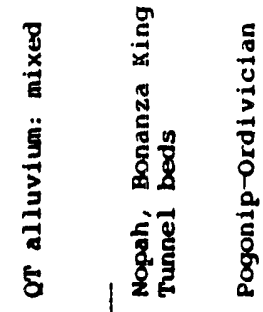

एँ

$0 \quad 00000$ 00000 00000 00000 00000 00000

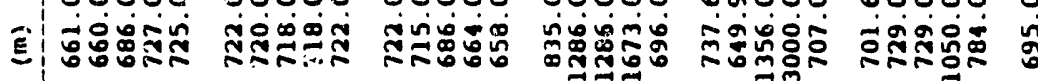

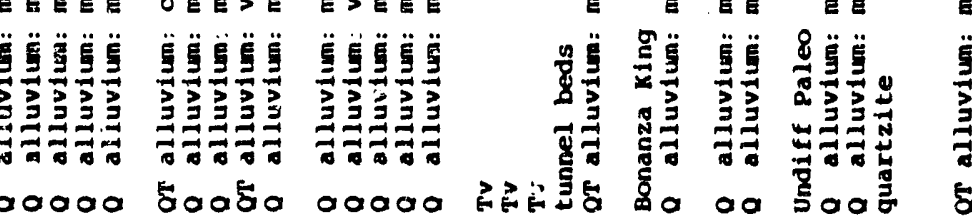
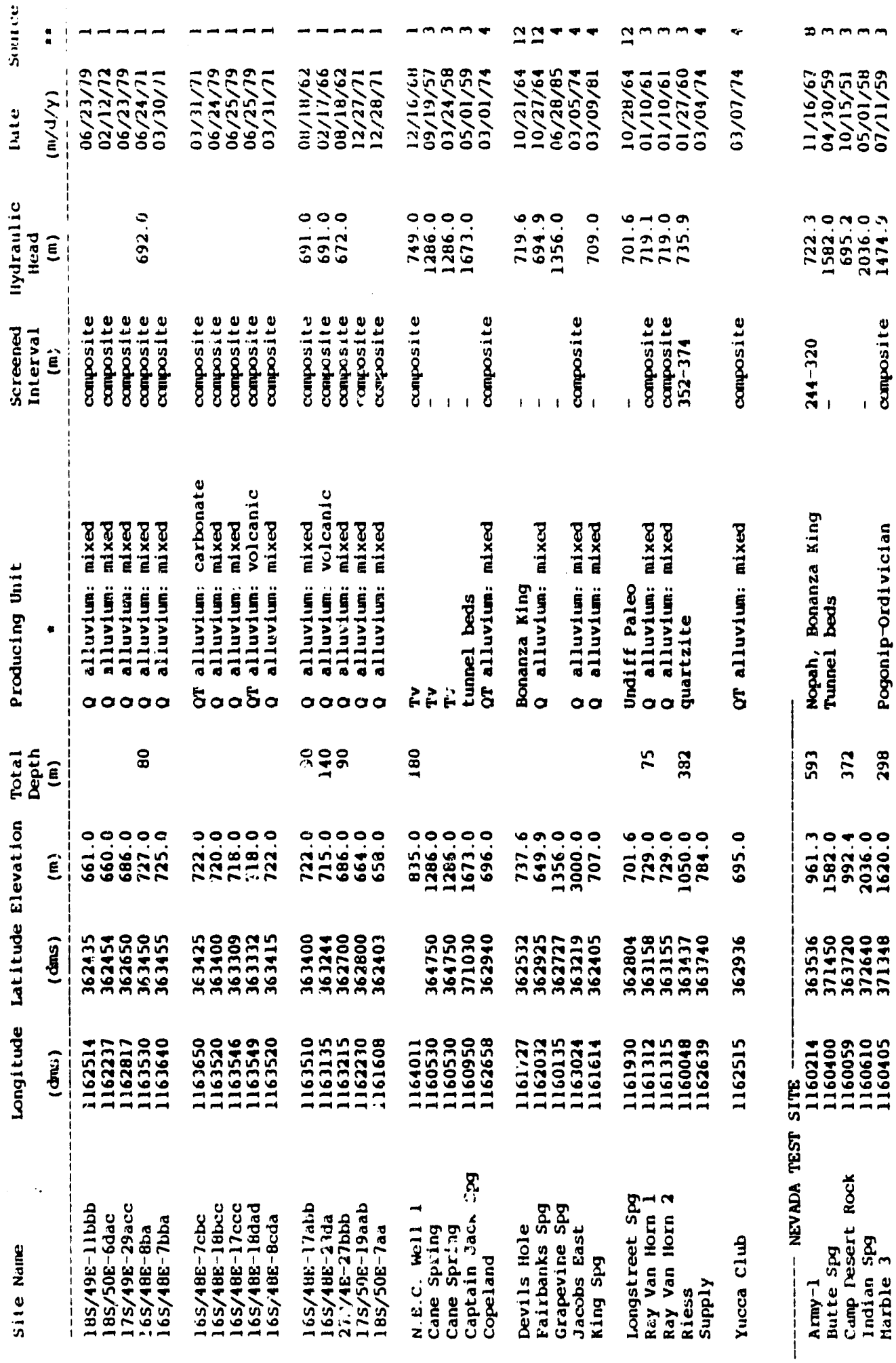


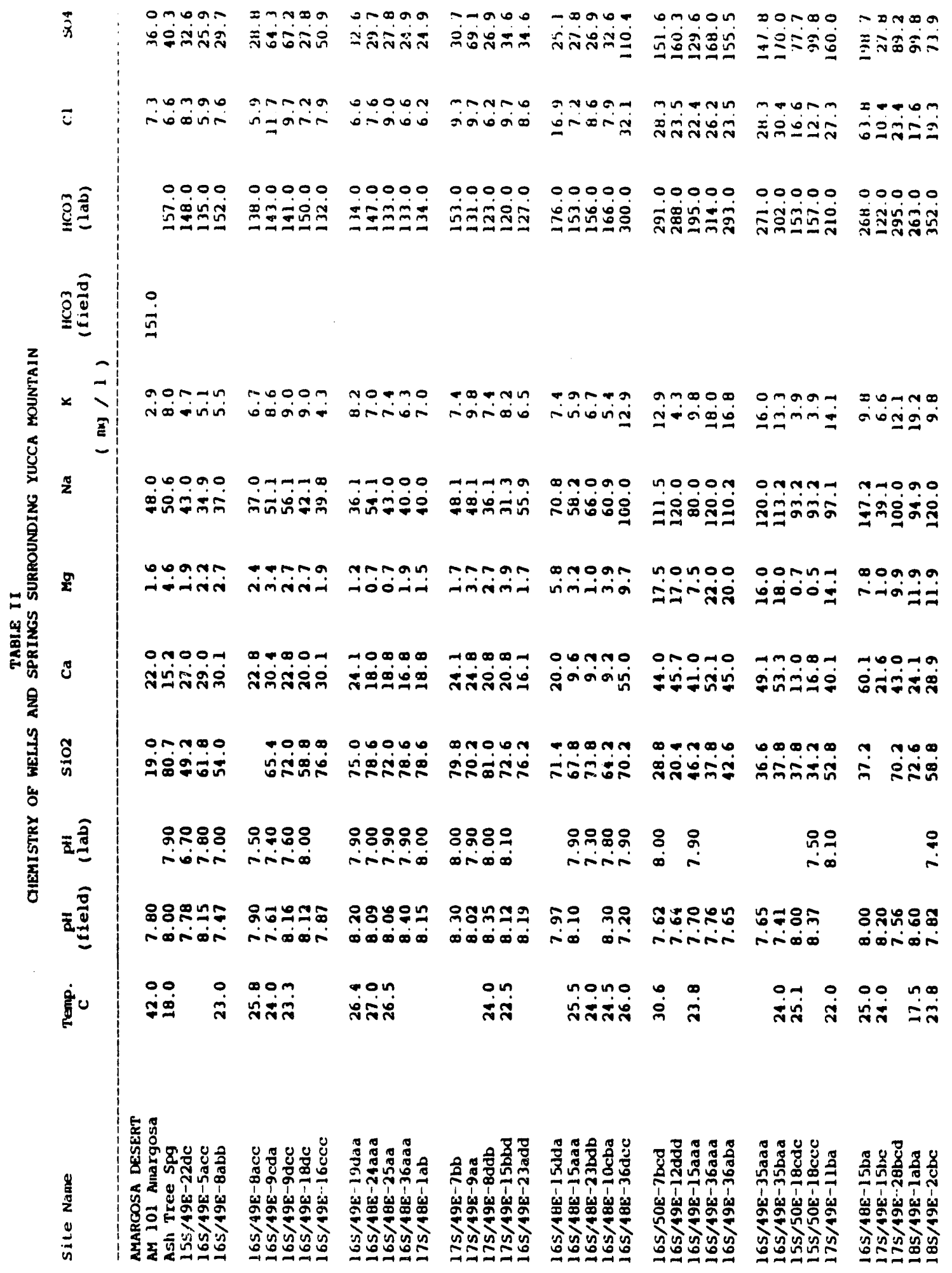




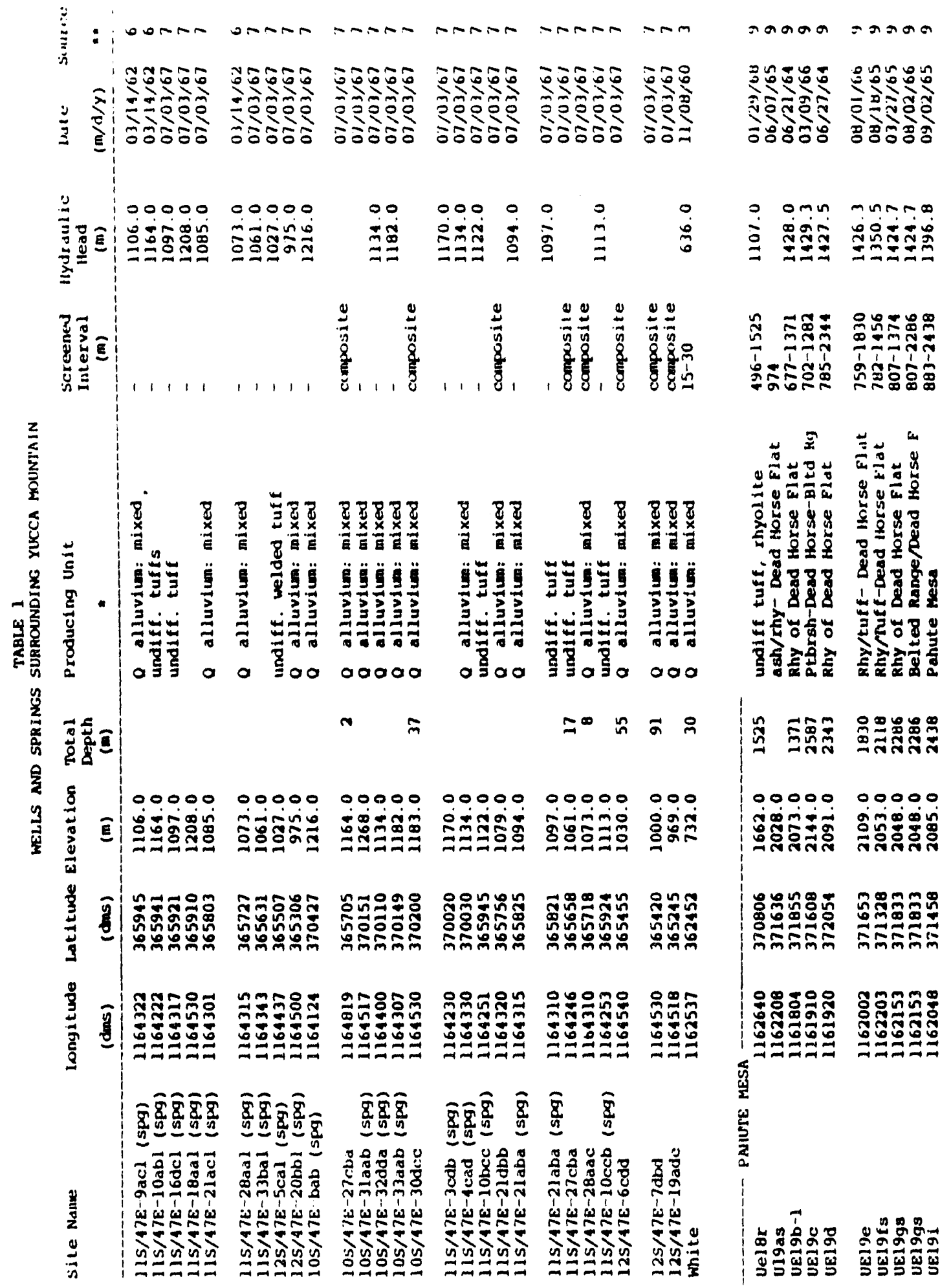


$\vdots$

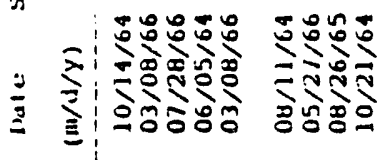
ב

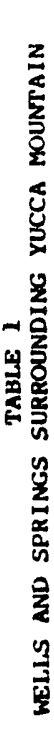

资

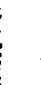

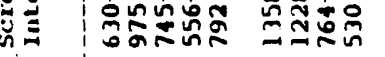

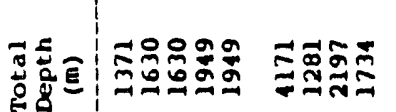

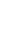

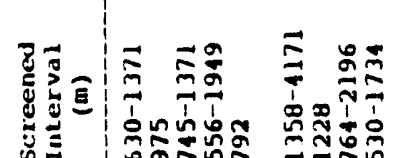

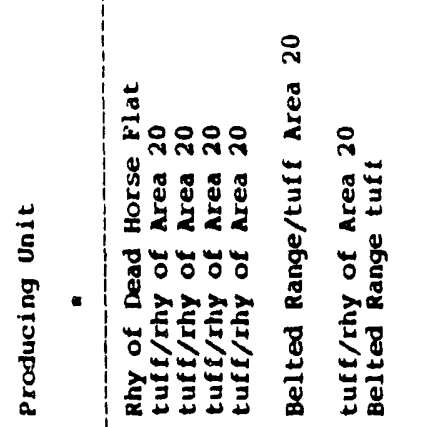

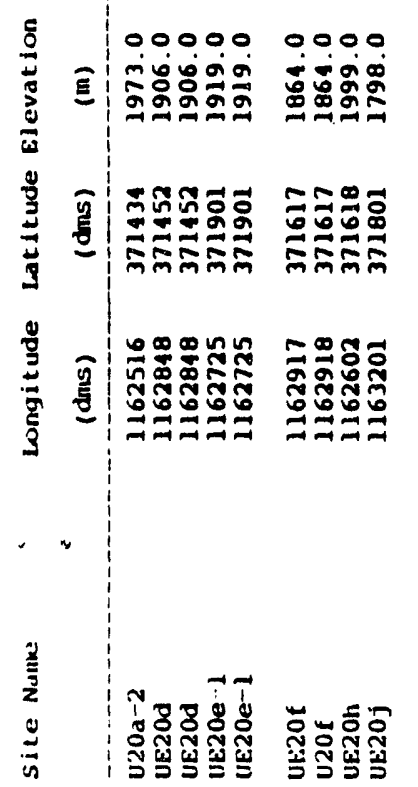

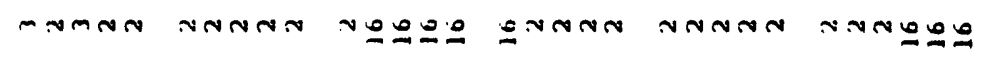

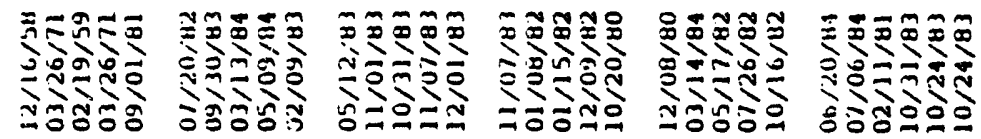

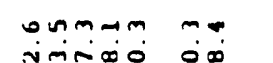

ำลำลำำ

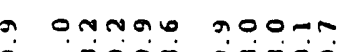

Trutico

ovmnan 政

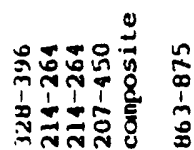

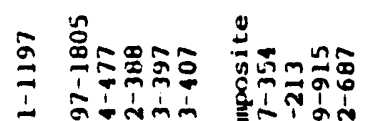

สิจัปิ

กํํํํํำ

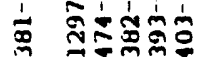

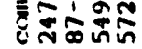

$\overrightarrow{3}=-\frac{5}{\mathbf{z}}$

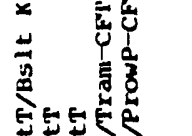

Es:

sisen

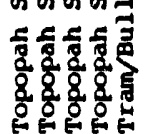

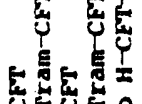

$8 \% 85$

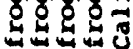

$\sum$

คํํํํํํำ

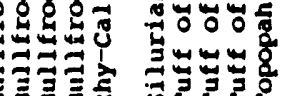

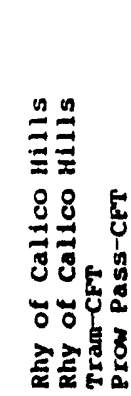

焉

ค용 동

on

onnmo

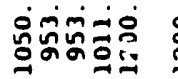

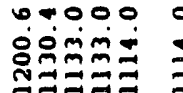

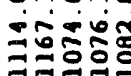

กทุดั

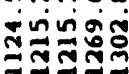

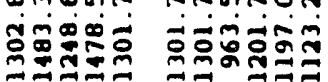

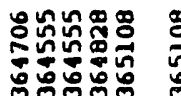

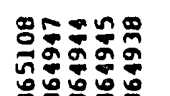

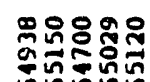

สำํำำง

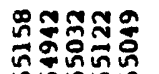

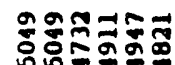

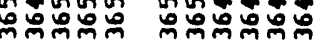

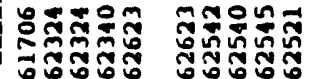 \\ $z \stackrel{0}{2}$ \\ 클}

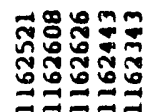

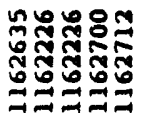

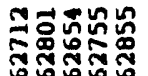

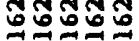

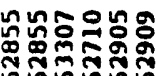

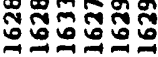

密

乌્ّ

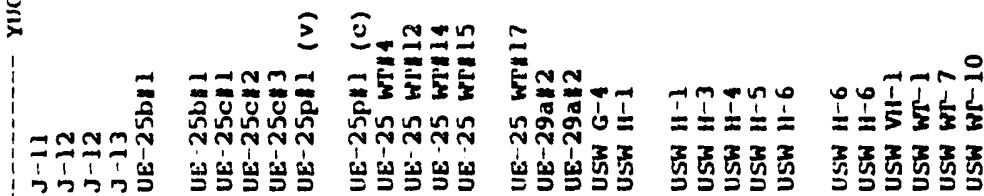


Footnotes:

* Stratigraphic Units of Wells: Table 1, and Winograd and Thordarson, 1975, p. 10-11.

** Sources 1-18, see list on page 128 . 


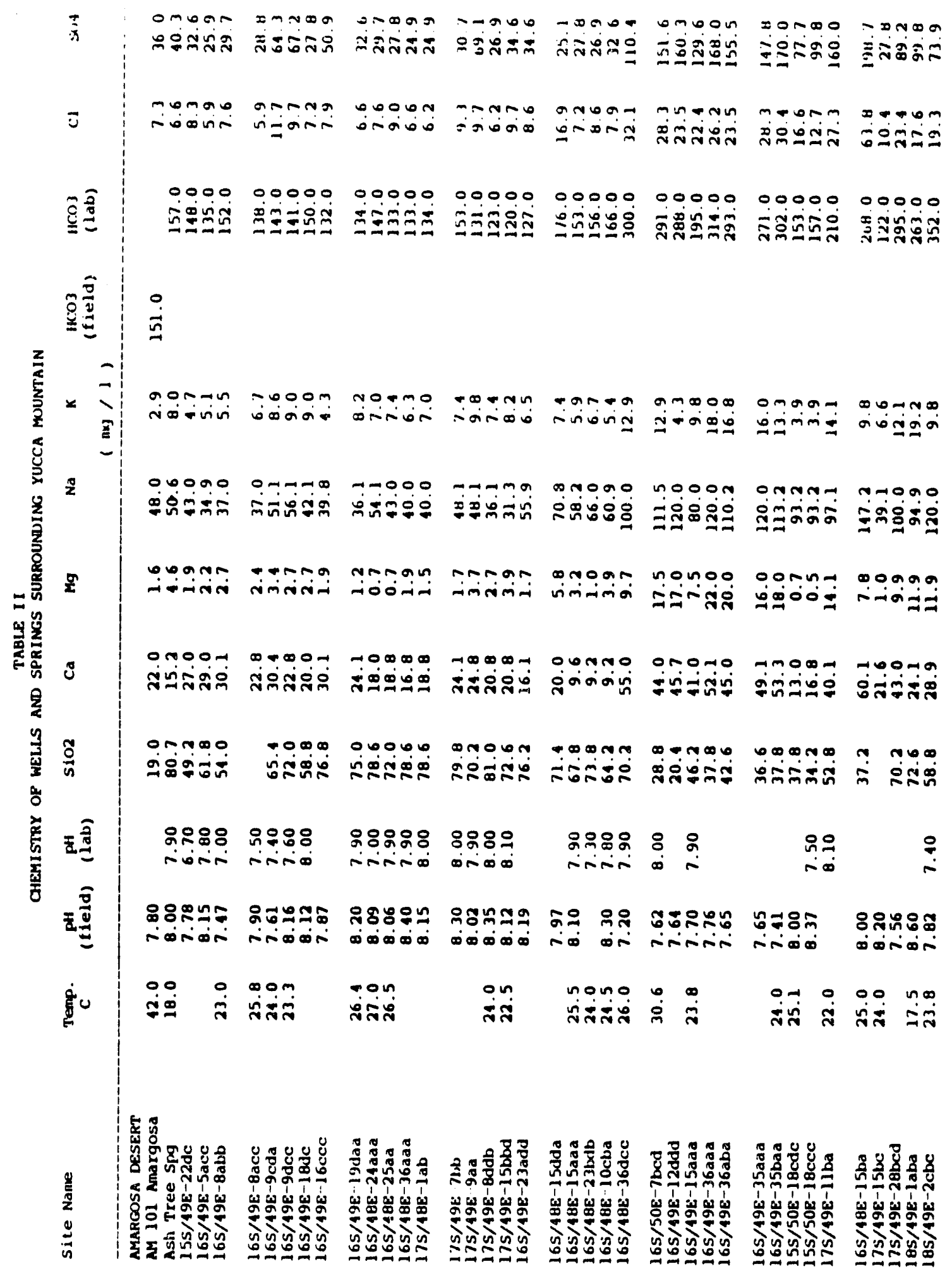




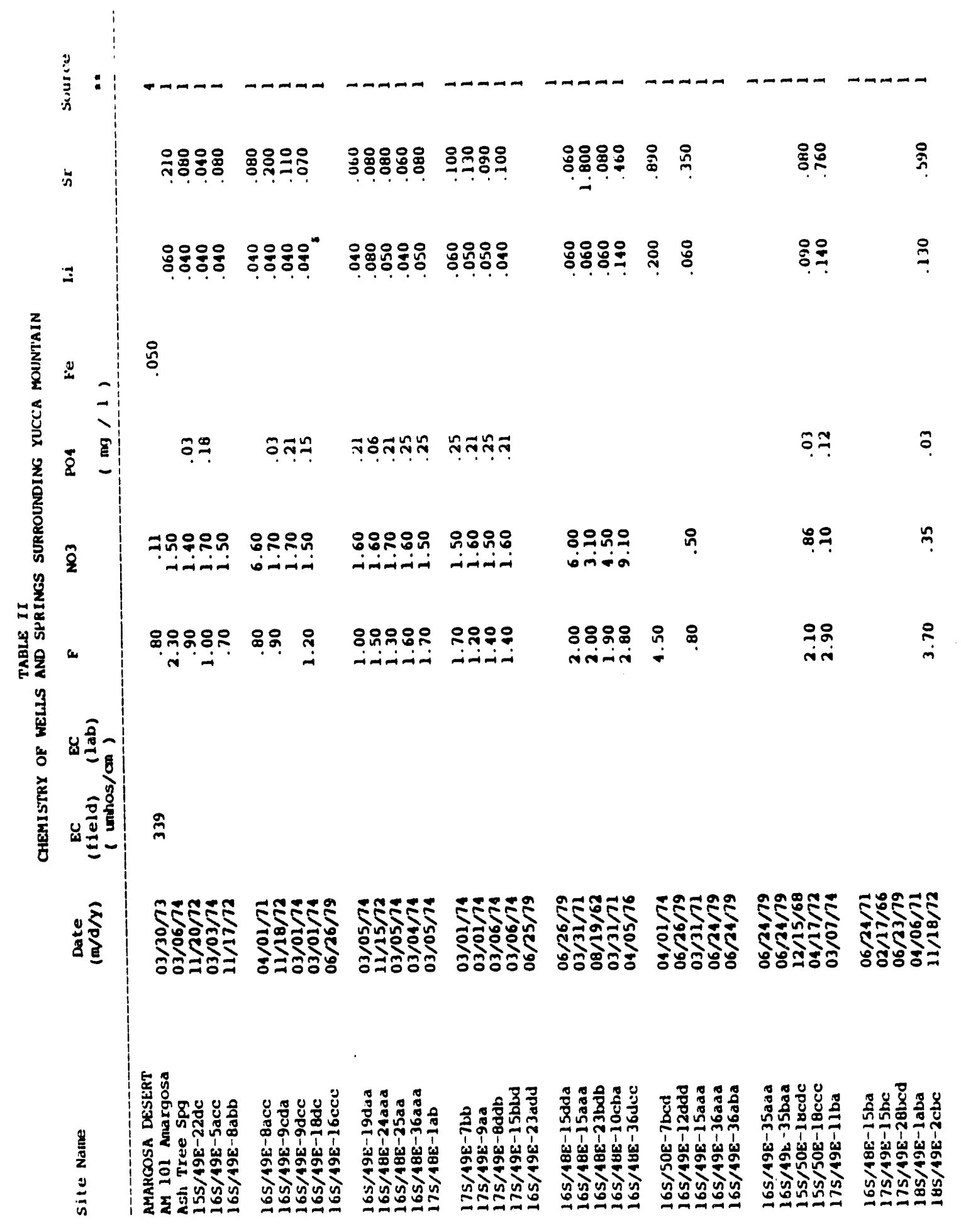




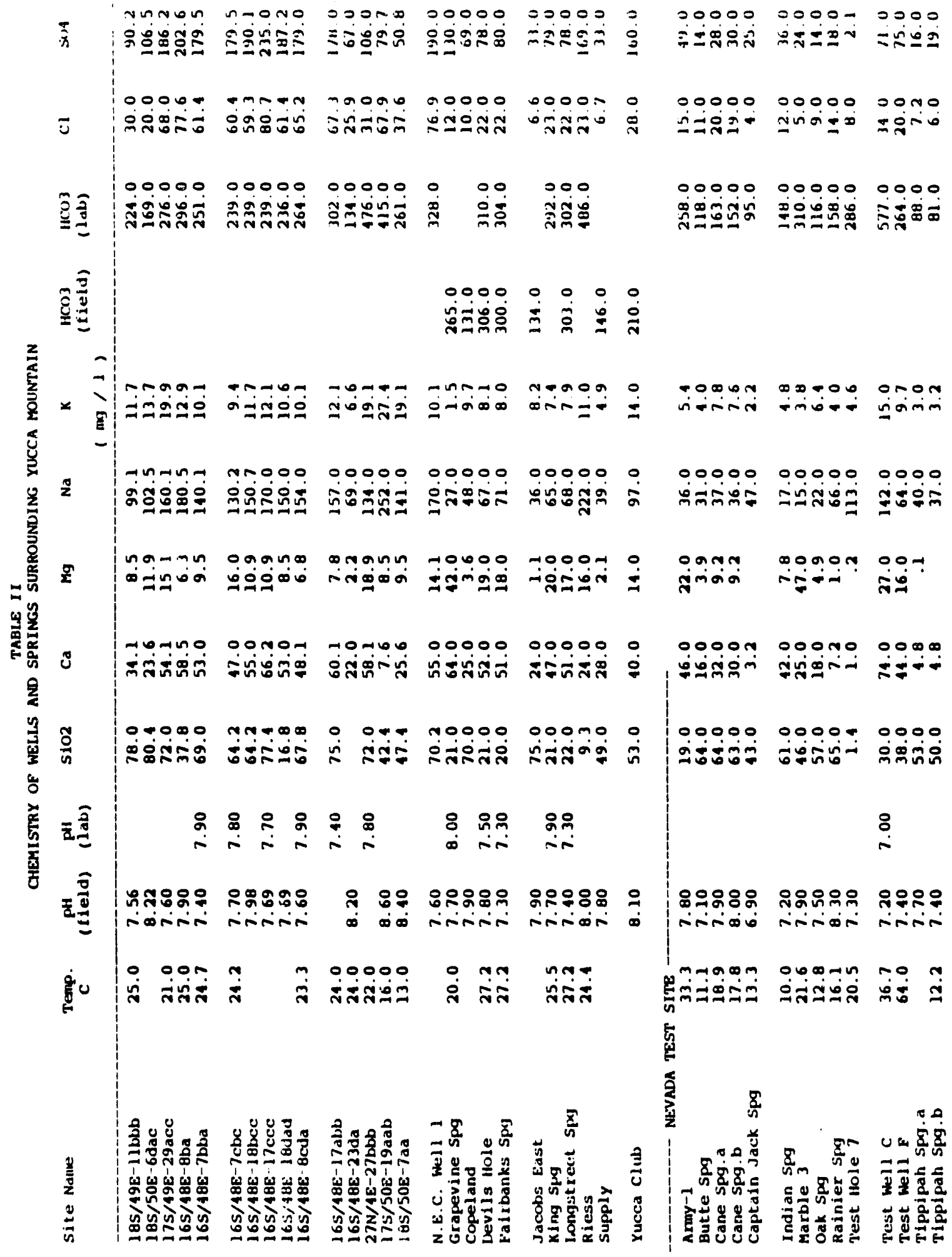




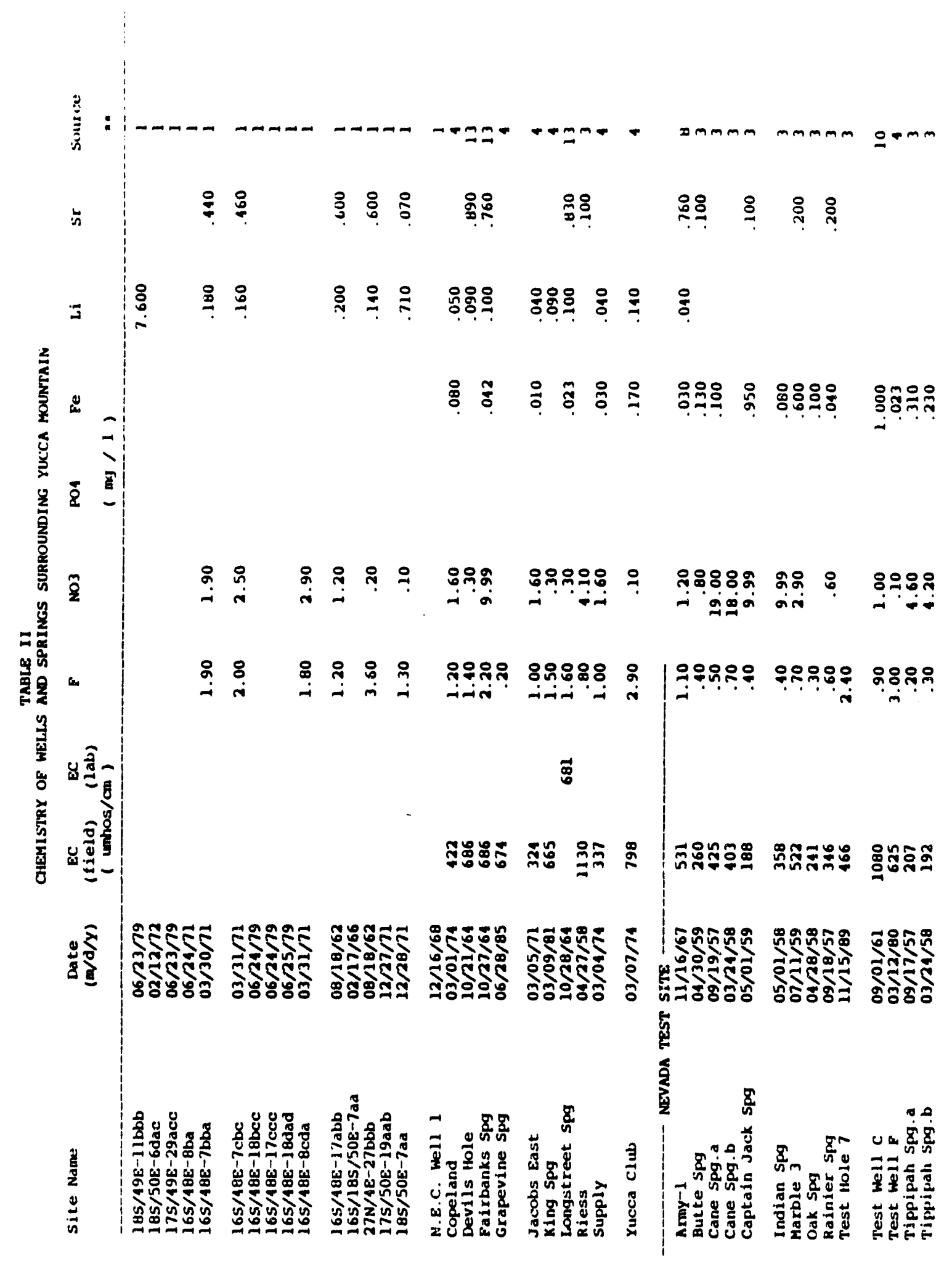




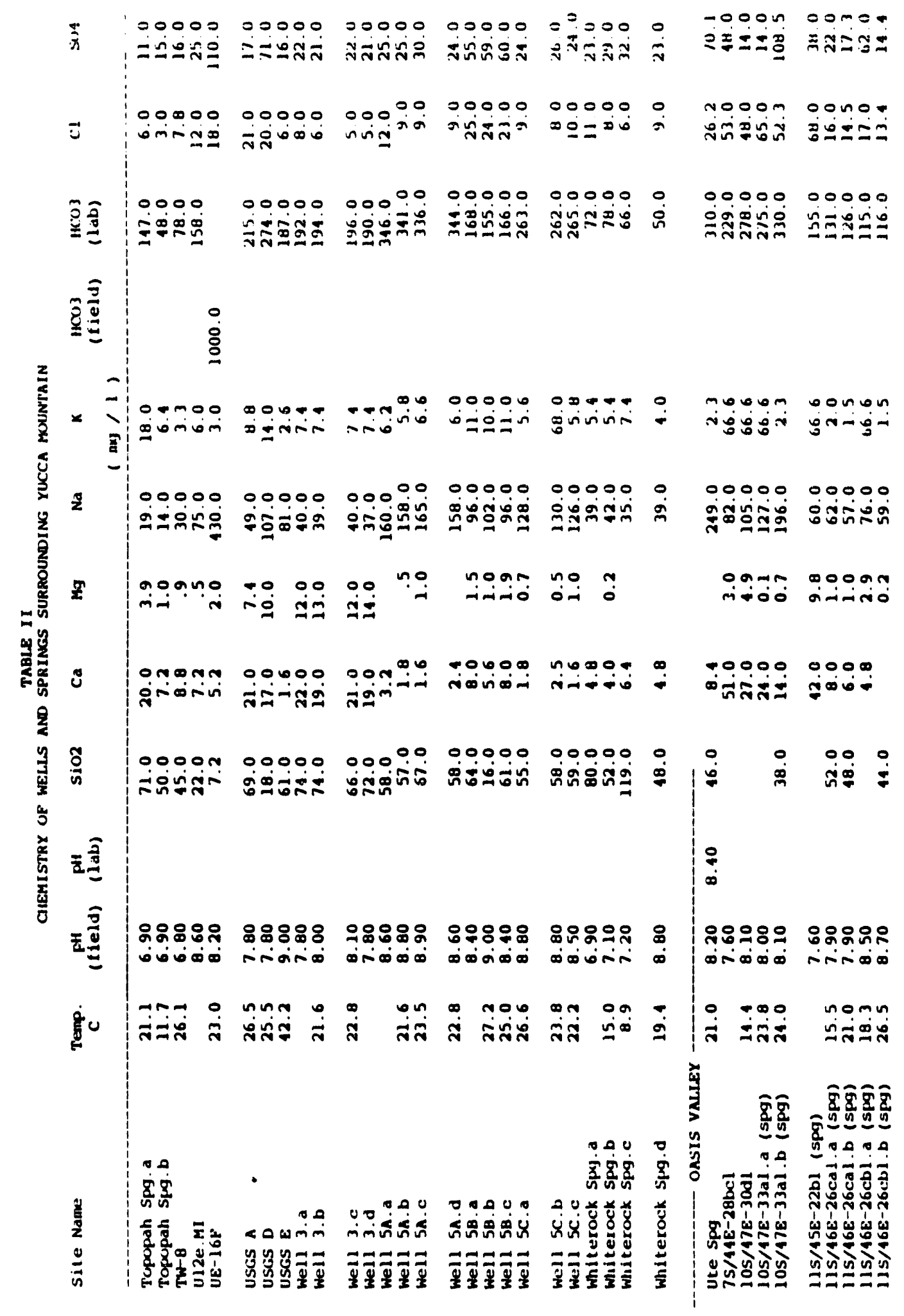




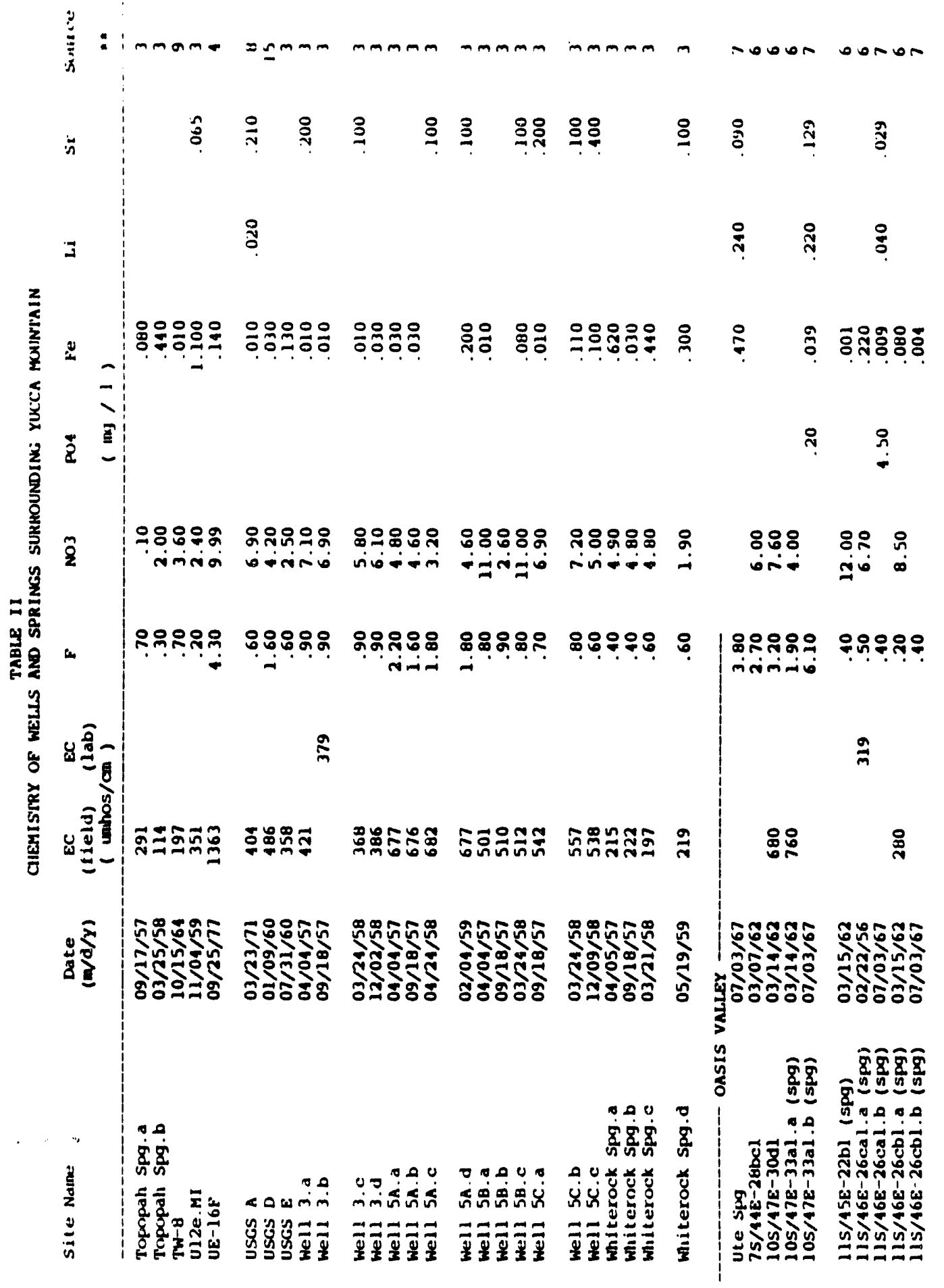




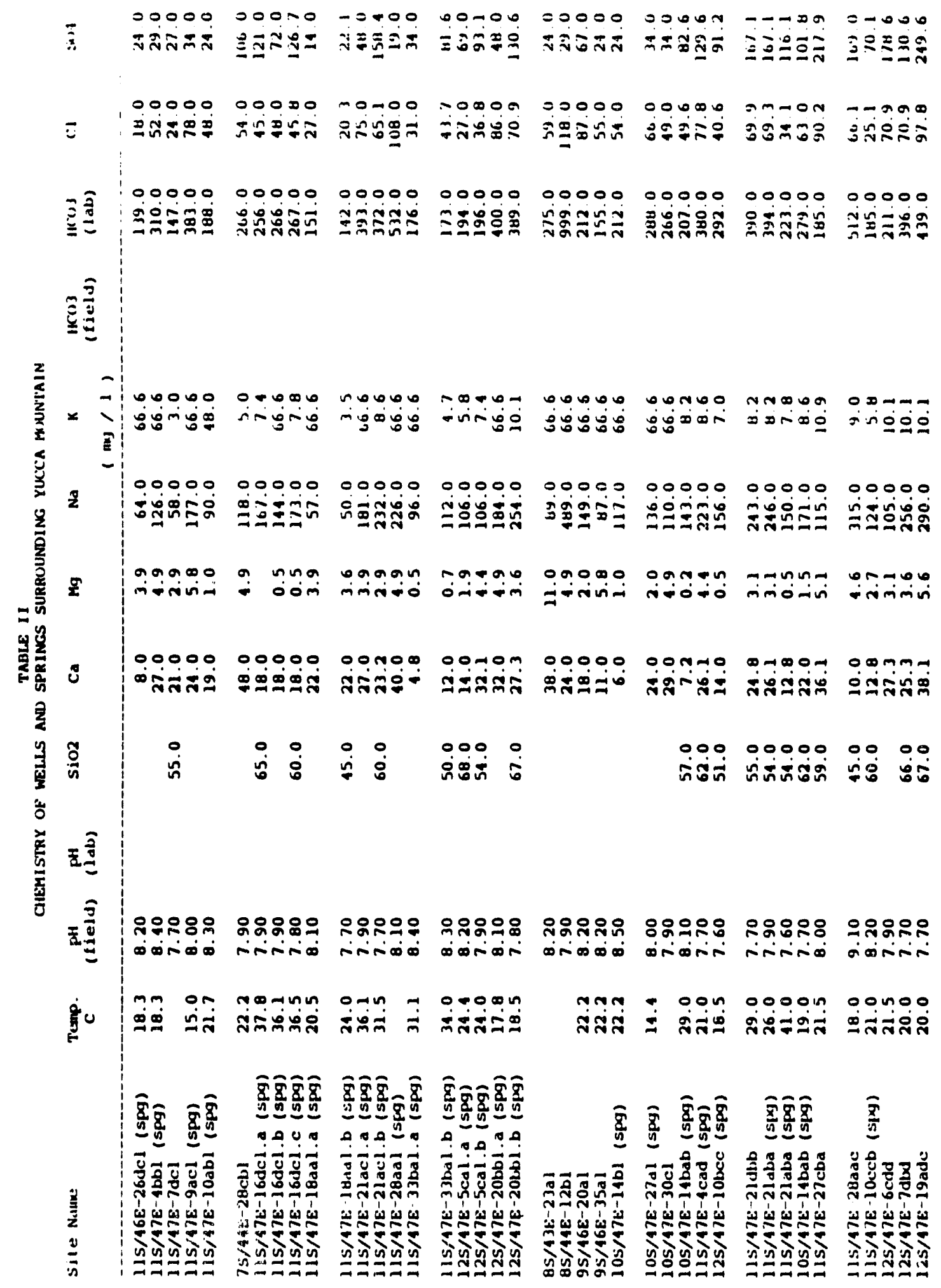




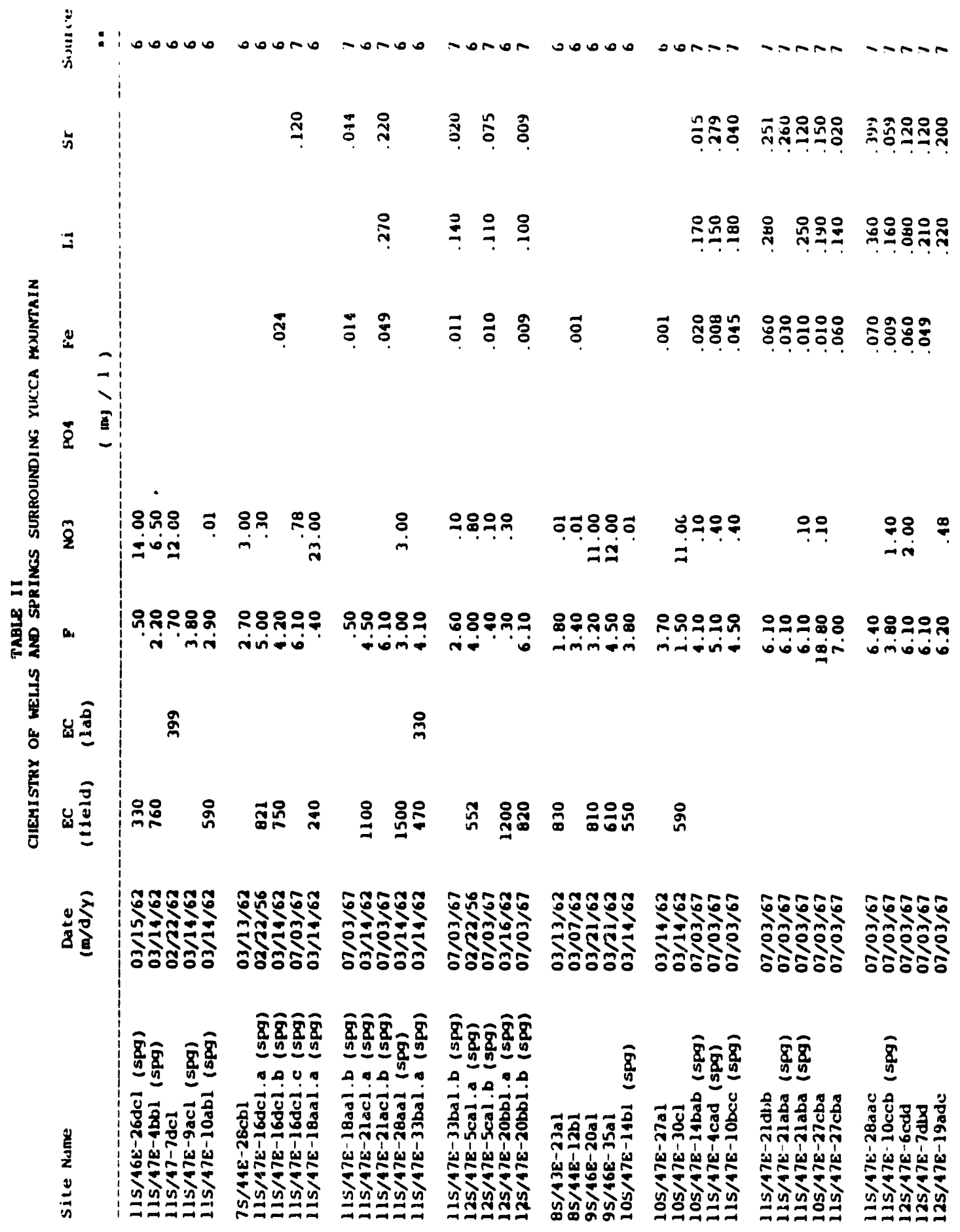




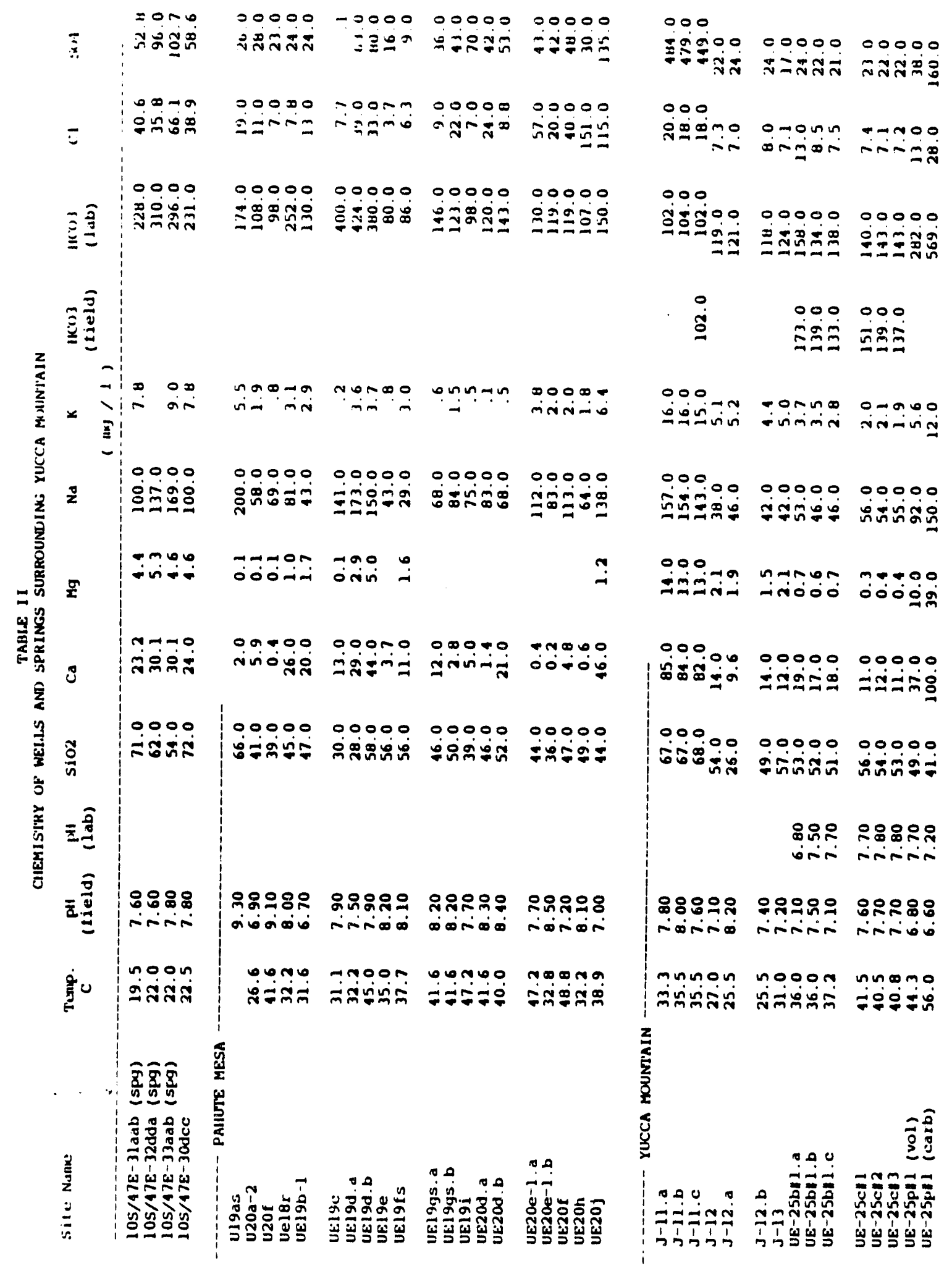




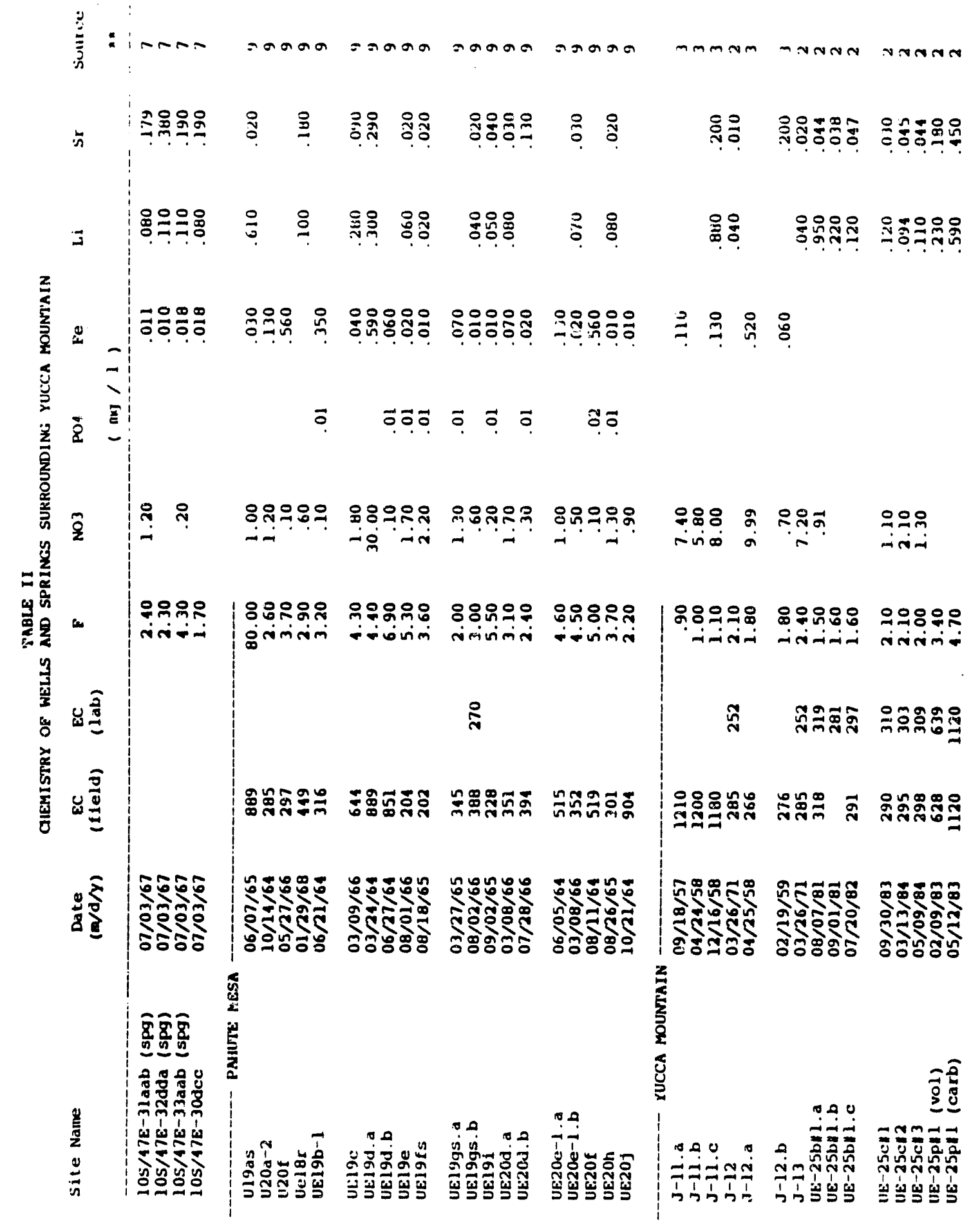




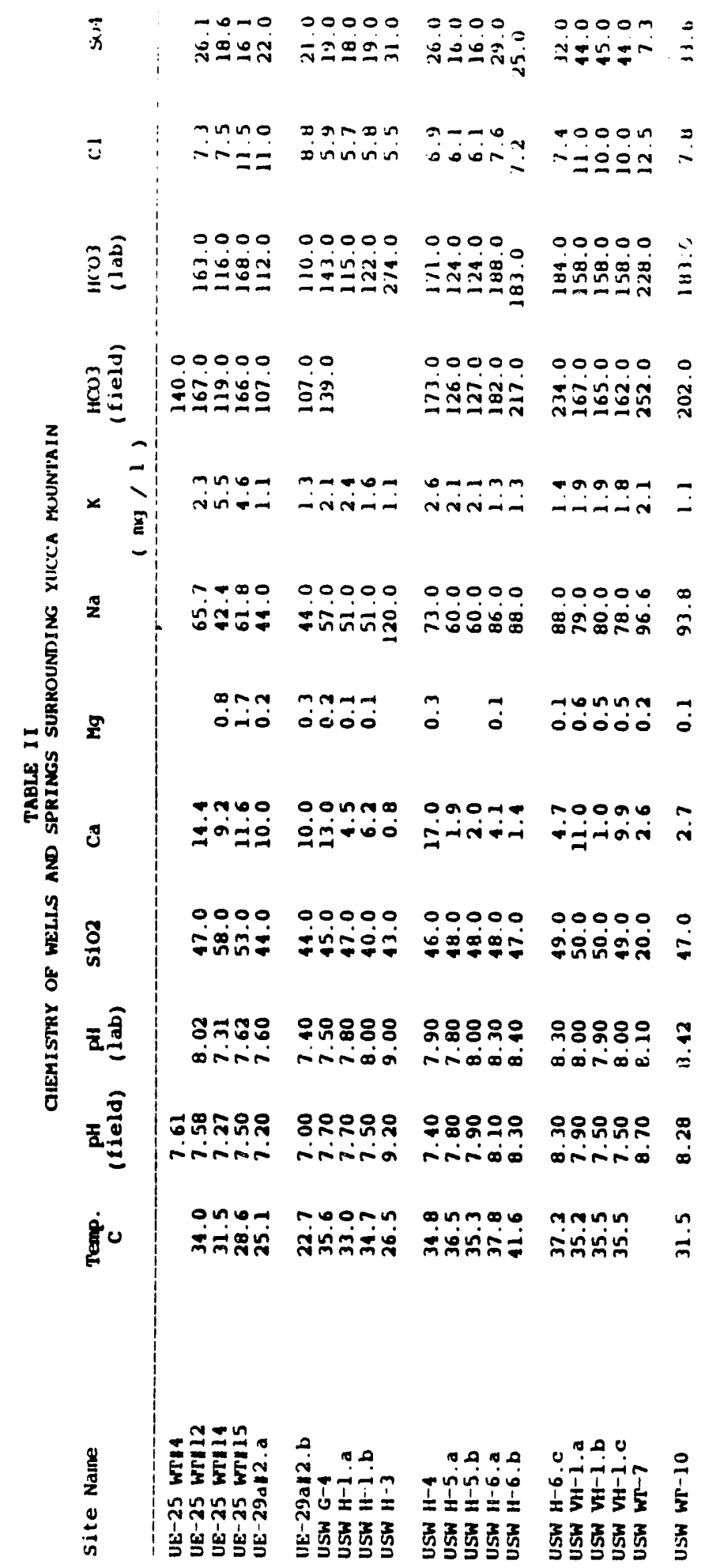




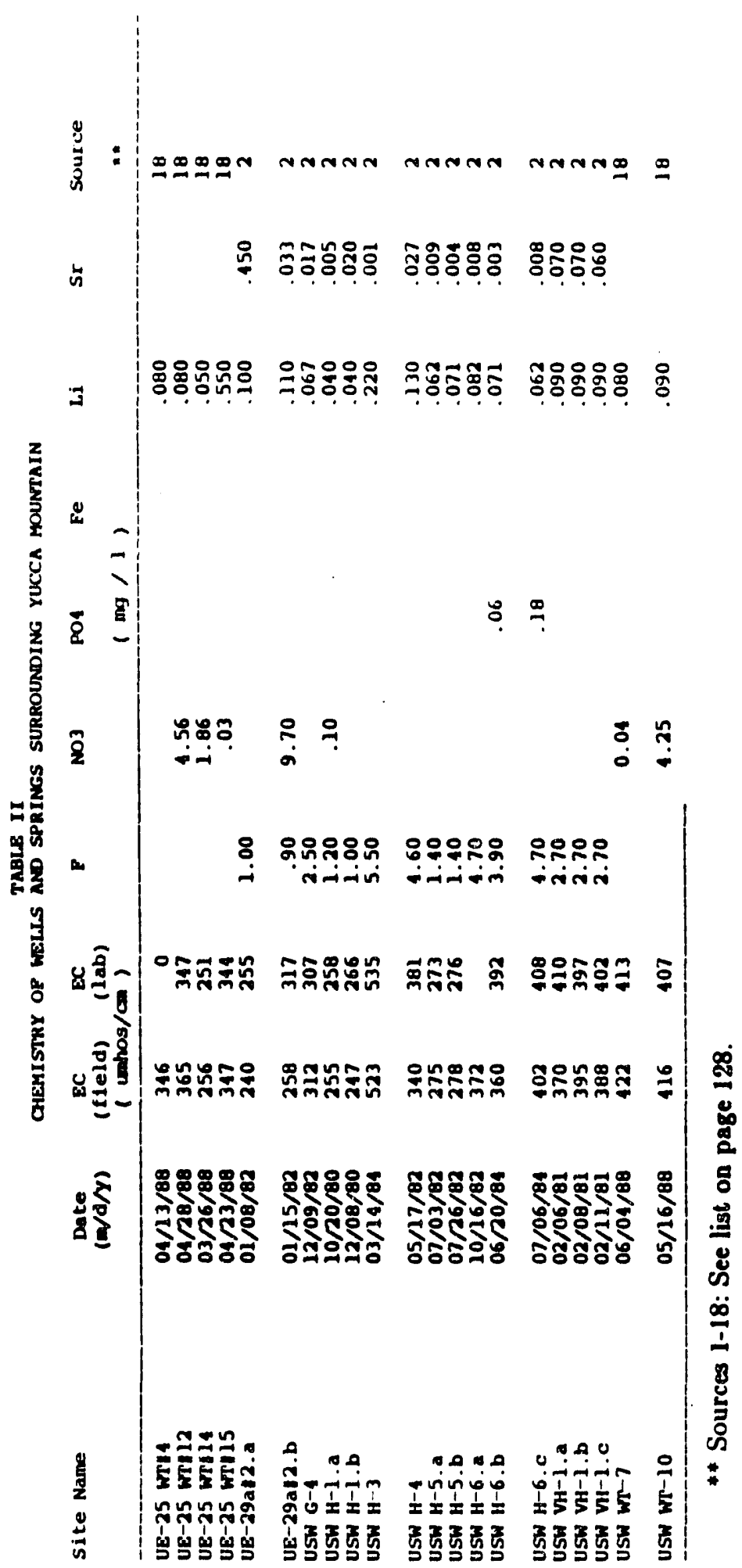




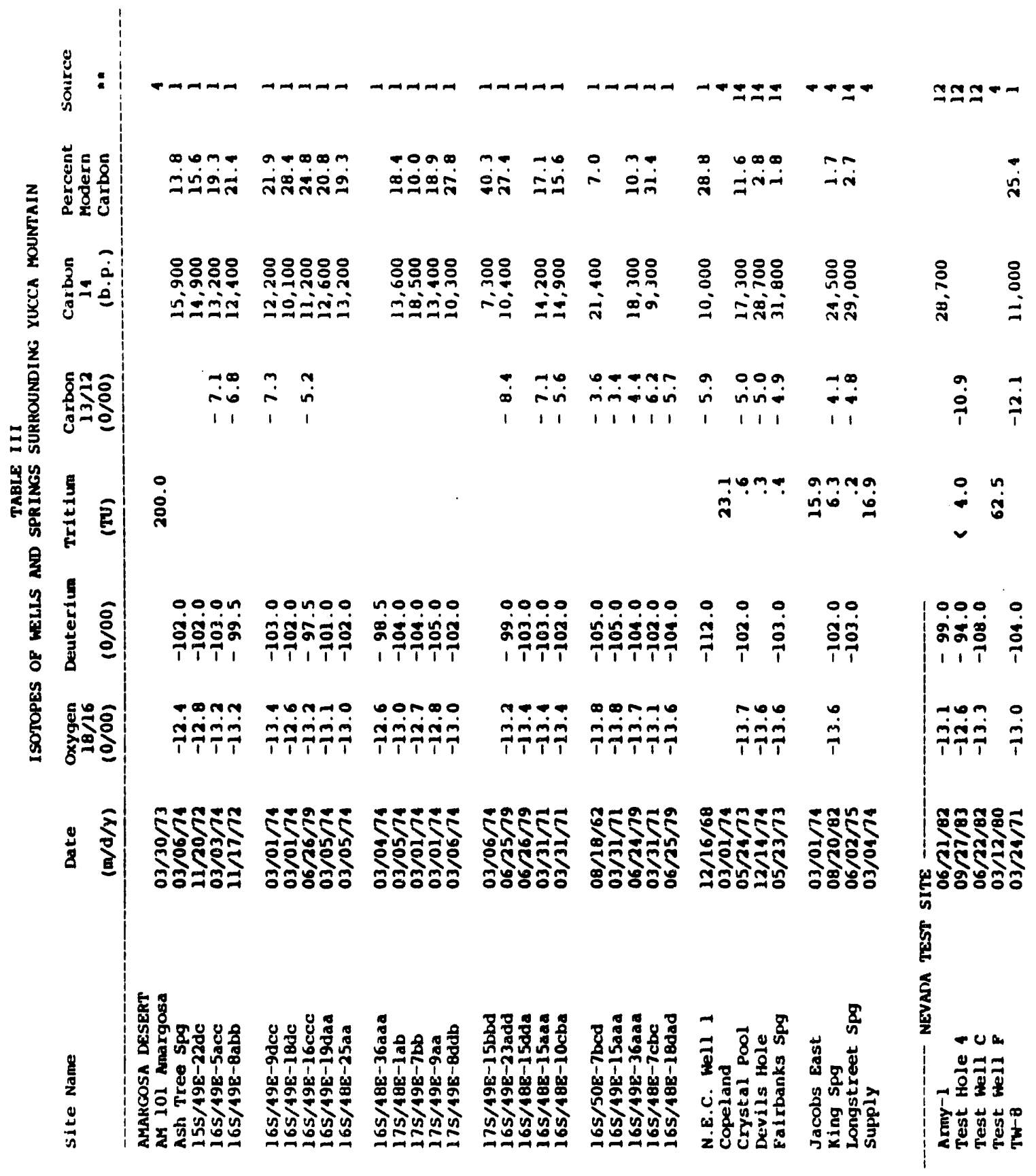




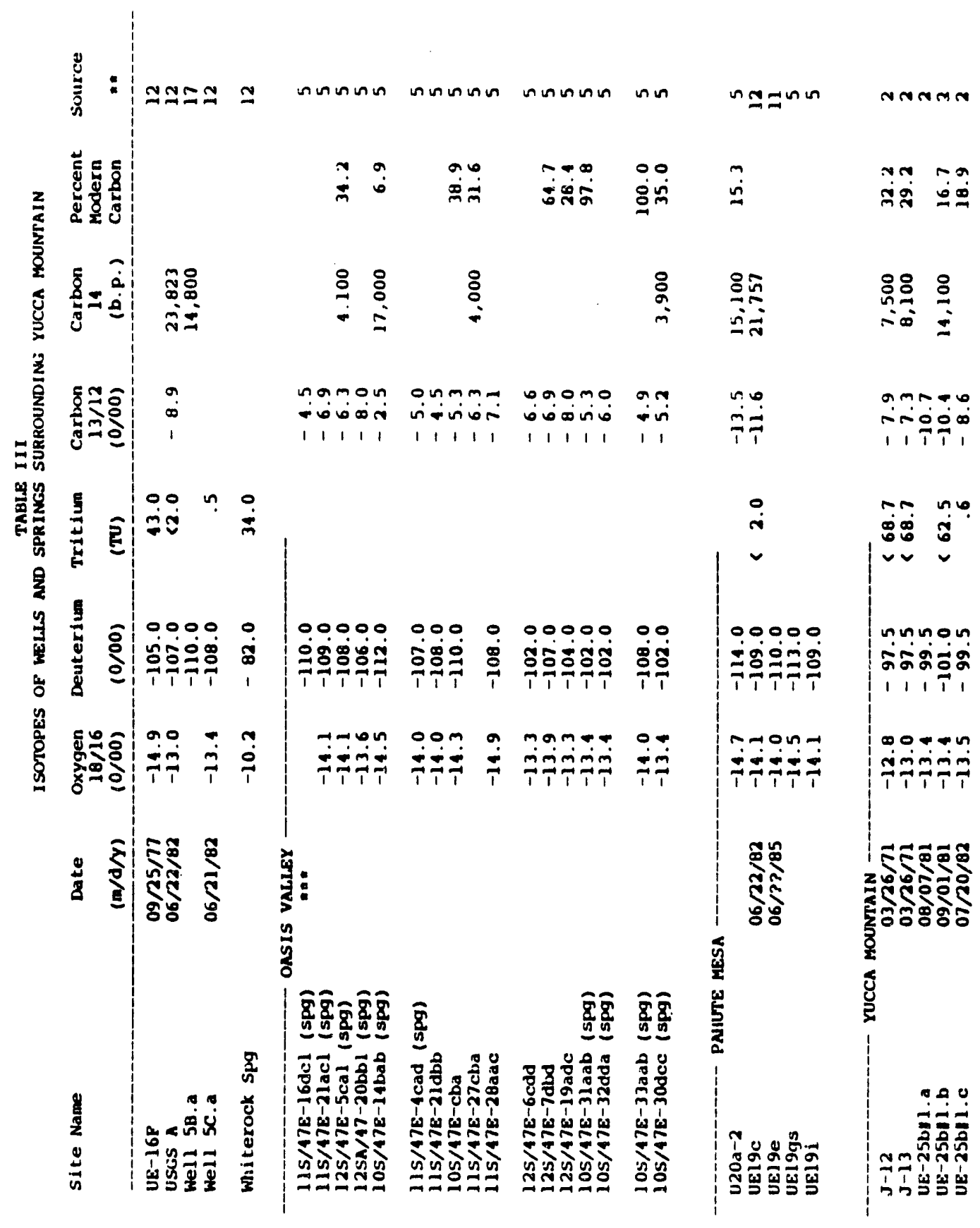




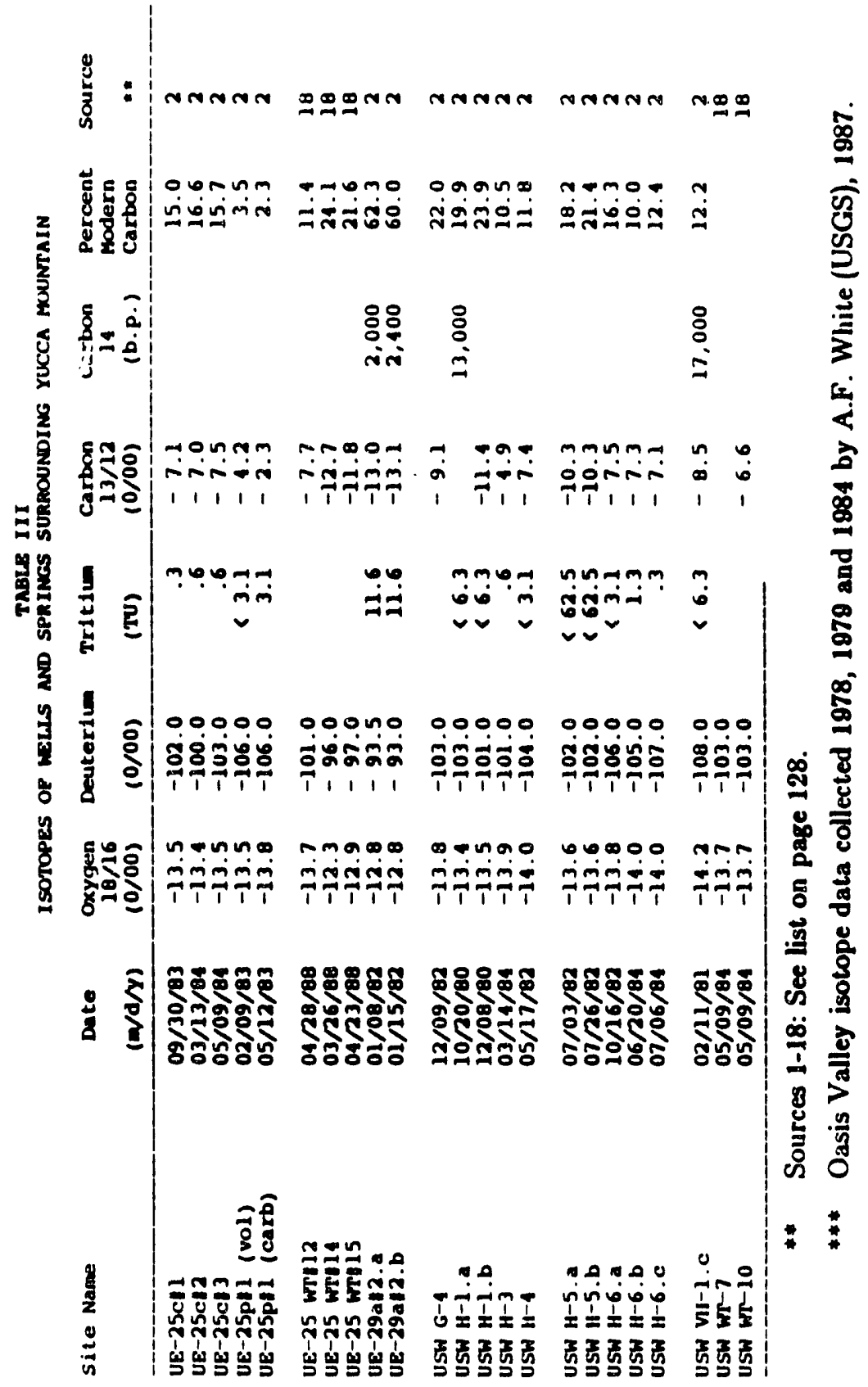




\section{DATA BASE REFERENCES}

1) Claassen, H.C., 1985.

2) Benson, L.V. and McKinley, P.W., 1985.

3) Moore. J.E., 1961.

4) Lyles, B.F., Jacobson, R.L. and Hess, J.W., 1987.

5) White, A.F. and Chuma, N.J., 1987.

6) Malmberg, G.T. and Eakin, T.E., 1962.

7) White, A.F., 1979.

8) Claassen, H.C., 1973.

9) Blankennagel, R.K. and Weir, J.E., 1973.

10) Garber, M.S. and Thordarson, W., 1962.

11) Feeney, T.A., 1987.

12) Boughton, C.J., 1986.

13) Robinson, B.P. and Beetem, W.A., 1975.

14) Winograd, I.J. and Pearson, F.J. Jr., 1976.

15) Thordarson, W., Garber, M.S. and Walker, G.E., 1962.

16) Robison, J.H., 1984.

17) Waddell, R.K., Robison, J.H. and Blankennagel, R.K., 1984.

18) Matuska, N.A., 1988 (this study). 


\section{APPENDIX B}

COMPUTER LISTING OF PHREEQE FLOW PATH AND MIXING MODELS

1: PHREEQE Input

2: Thermodynamic Data

.3: Sample PHREEQE Output 
$\underset{\sim}{\stackrel{6}{\sim}}$

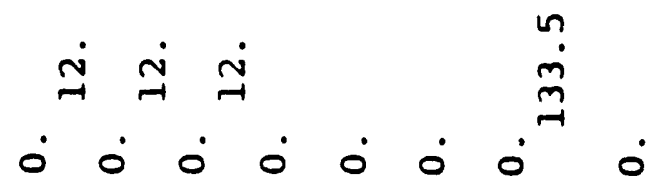

告造

令

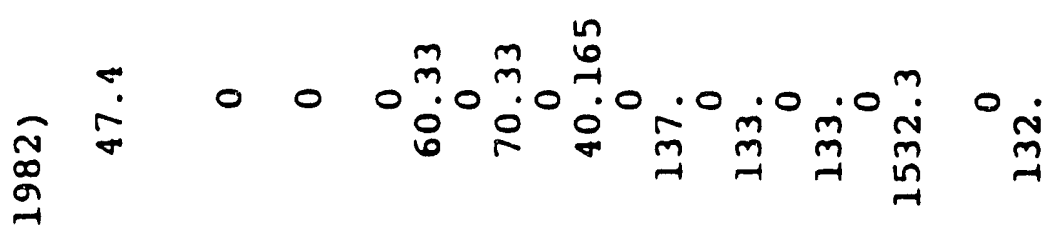

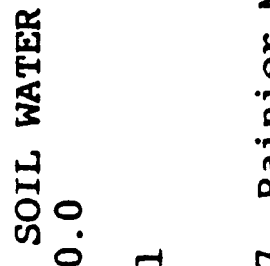

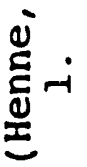

\% ก ?

$\stackrel{\infty}{\stackrel{0}{0}}$

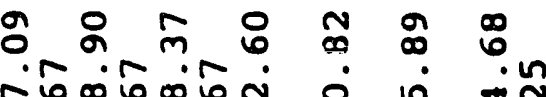
in 0 .

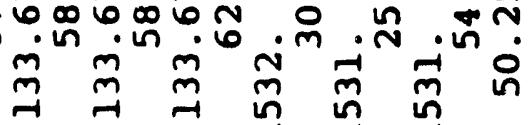
$\sum$ in $\sim 20$

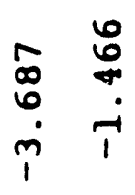

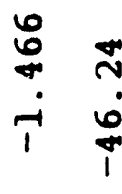

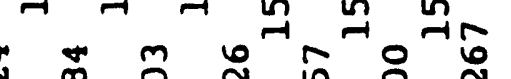

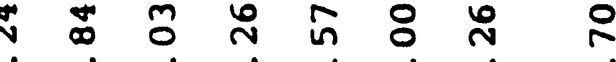

$\dot{1}$

$\stackrel{0}{i} \stackrel{1}{1}$

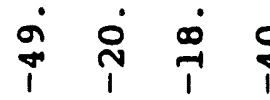

ָี

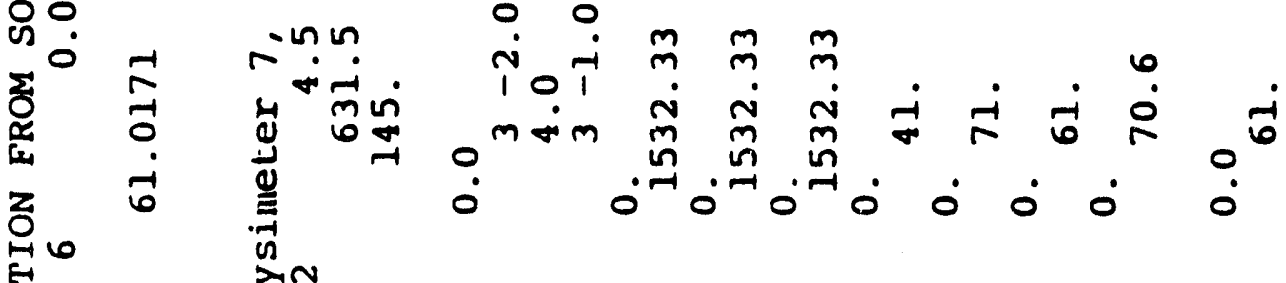

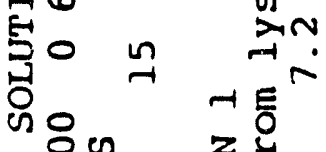

州望

Z乐

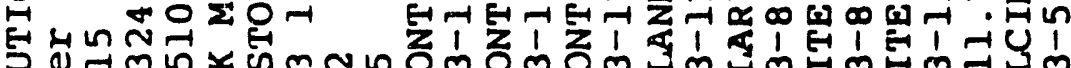

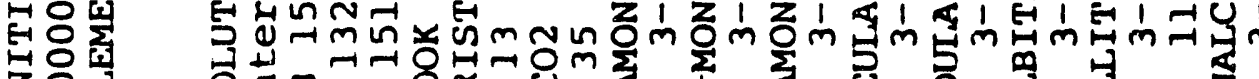

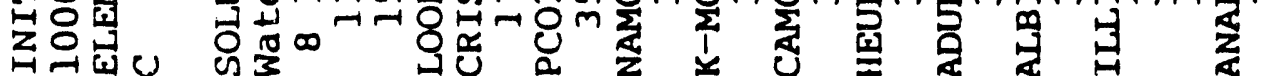




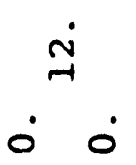

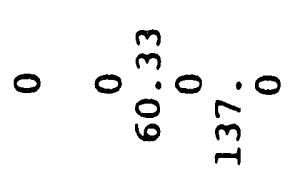

$\stackrel{0}{\infty}$

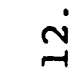

$\circ \dot{0}$

$\dot{0}$

$\stackrel{1}{0}$

- $0 \stackrel{m}{\dot{m}} 0 \stackrel{m}{m}$

$\stackrel{N}{N}$

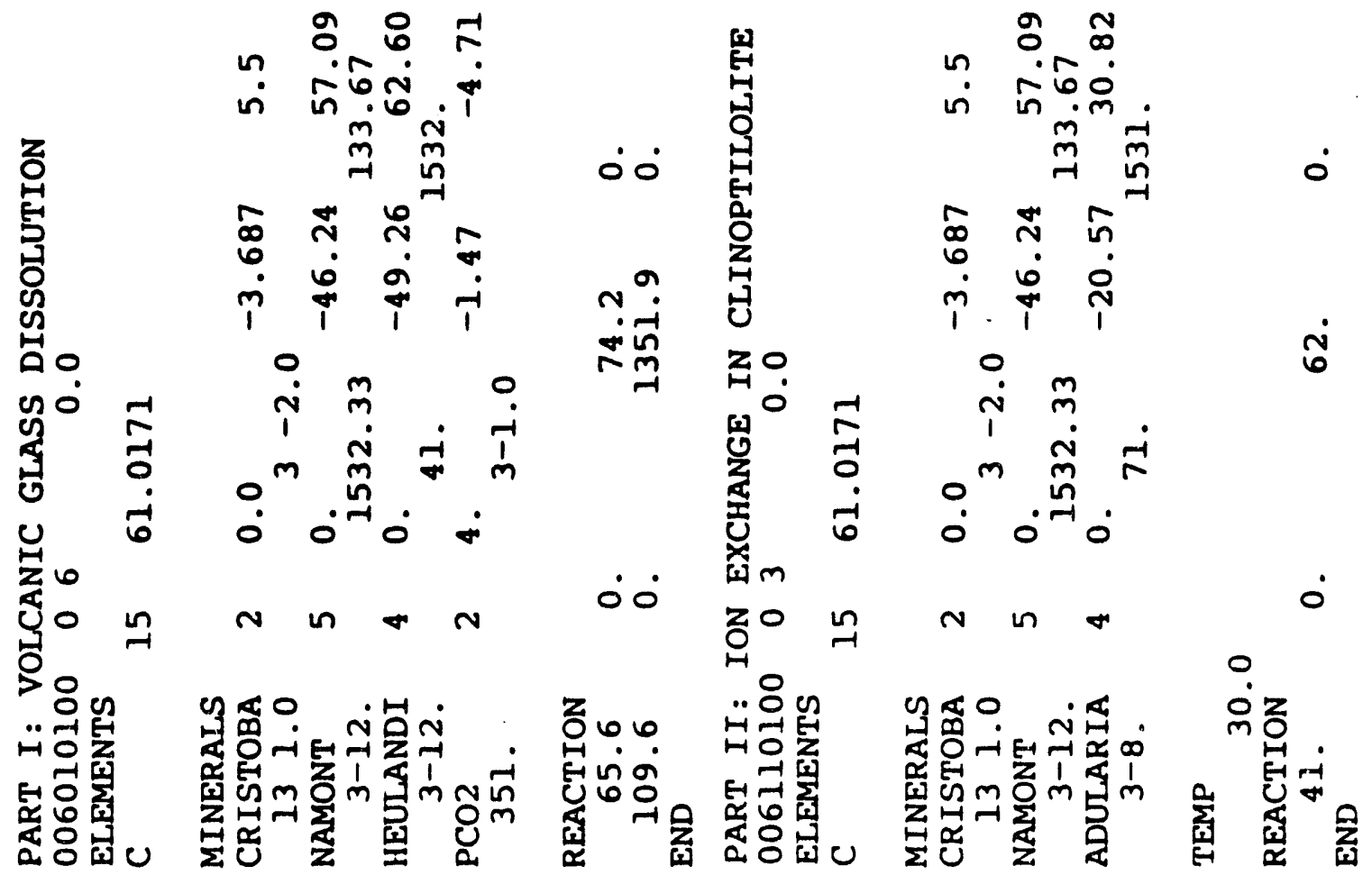




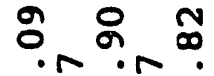

資

Zo

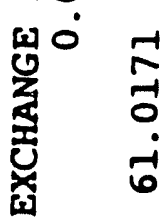

$z^{m}$

임

$\ddot{ت} \circ$ 용

범에

억

터을

囱ㅇㅇㅇ본
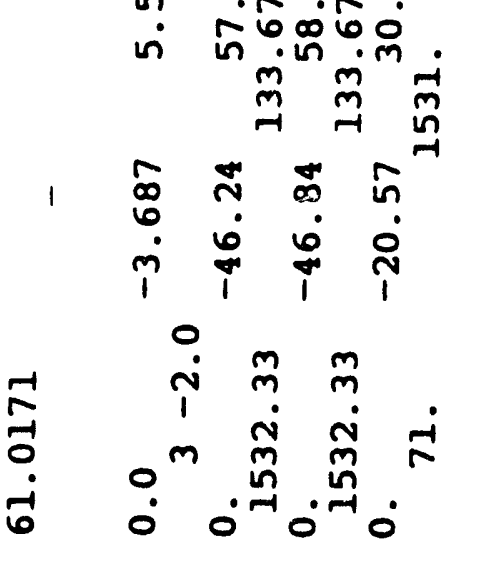

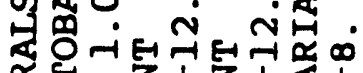

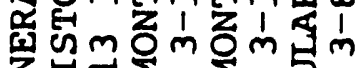

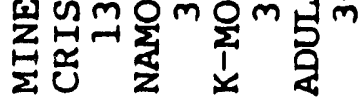

$$
\begin{aligned}
& \stackrel{\sim}{\sim} \stackrel{-}{\sim} \\
& \dot{0} \dot{0} 0
\end{aligned}
$$

- $0 \stackrel{m}{m} \cdot \stackrel{m}{m}: 0 \underset{m}{m}$

i

$\stackrel{i}{n}$

ம்

$$
\begin{aligned}
& \stackrel{\sim}{\stackrel{-1}{\sim}} \underset{\sim}{\sim} \\
& \dot{0} 0 \dot{0}
\end{aligned}
$$

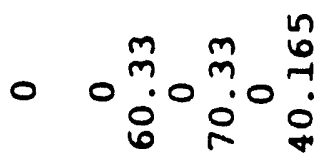

嵒

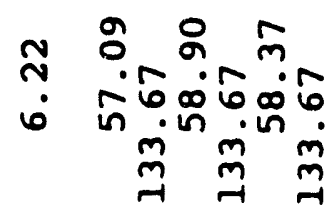

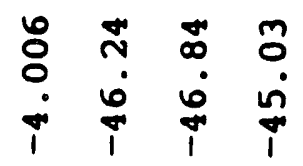

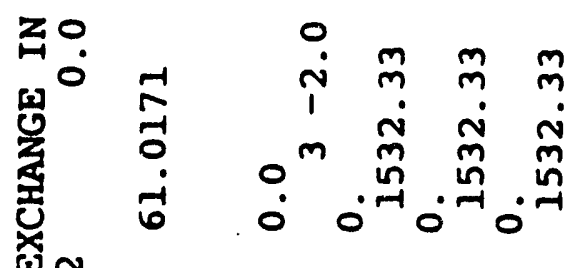

-

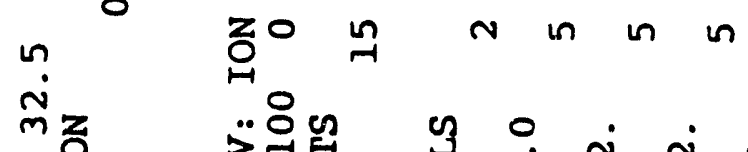

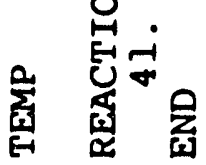

용요룔

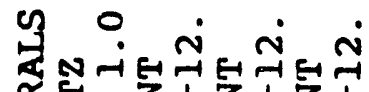

터들 왹

텀대욕

造品

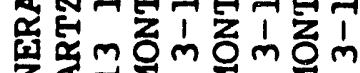

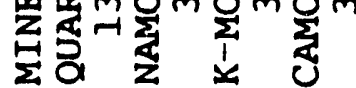




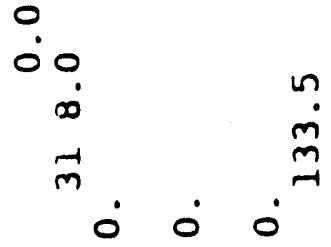

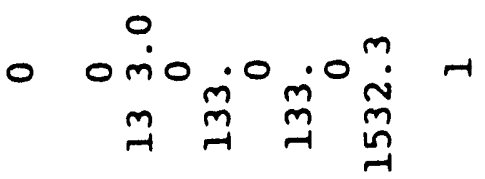

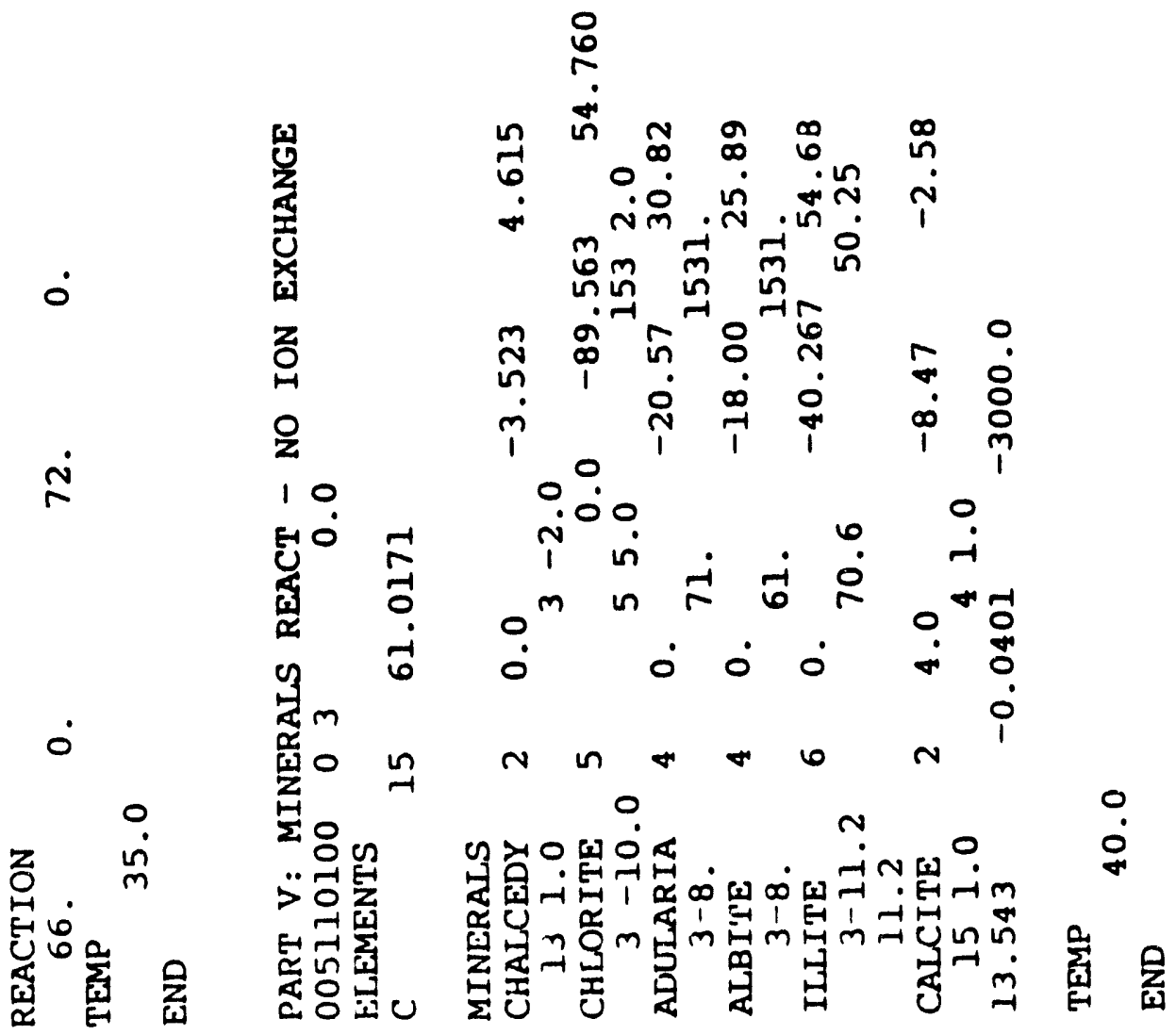




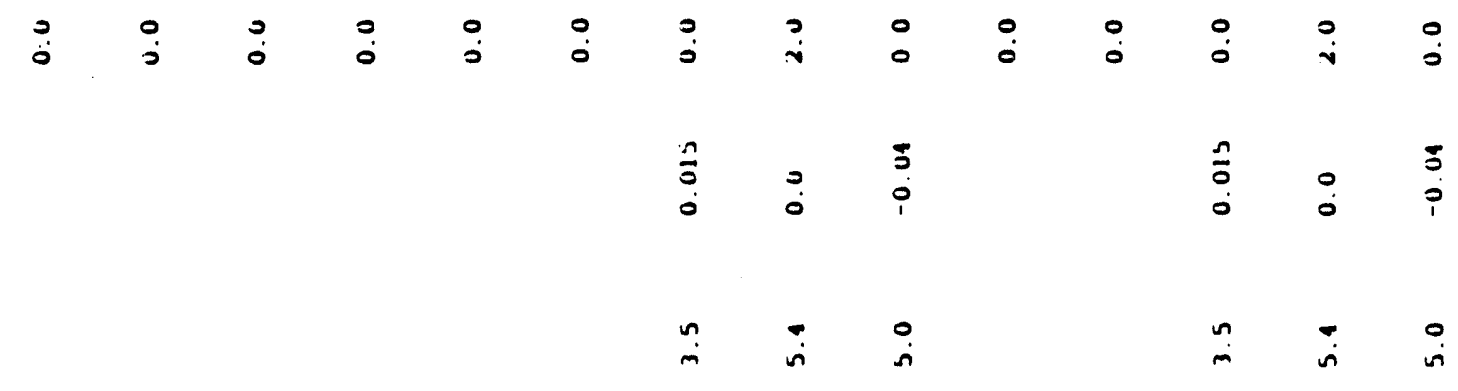

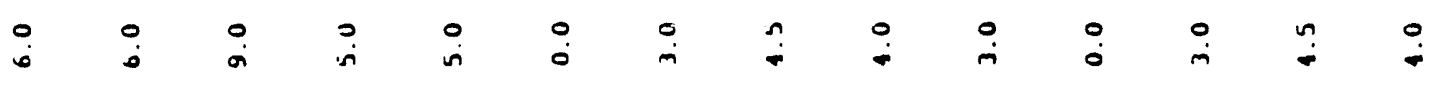

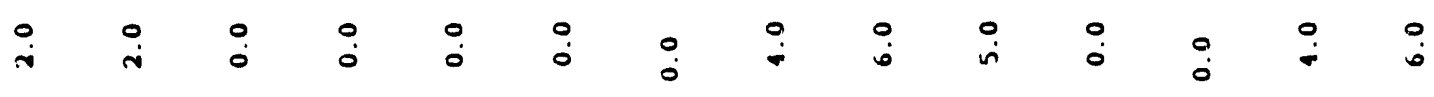

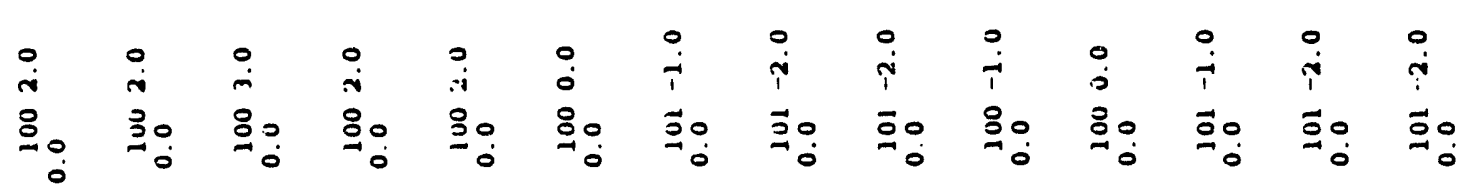

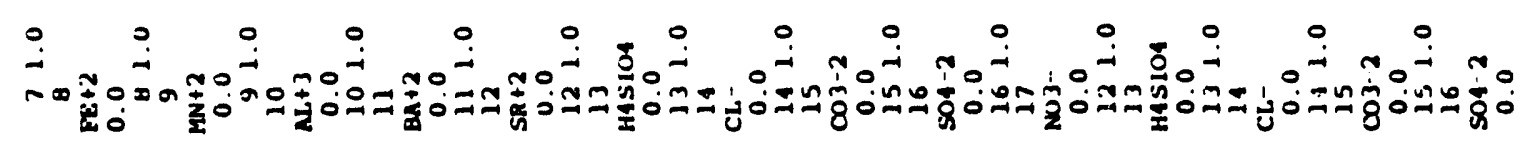
$\therefore: \div:: 0$ 产

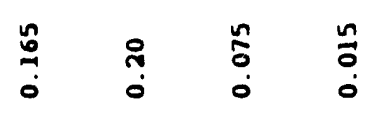
然 $\stackrel{n}{i}:$ $\therefore:: \div: \div$

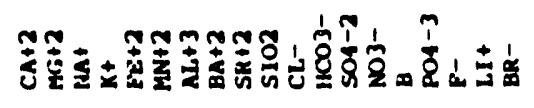
$\begin{array}{lllllll}0 & 0 & 0 & 0 & 0 & 0 & 0 \\ 0 & 0 & 0 & 0 & 0 & 0 & 0\end{array}$

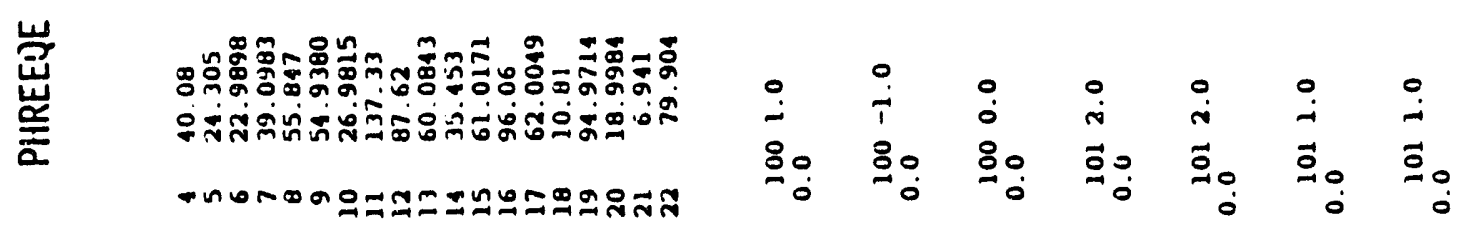

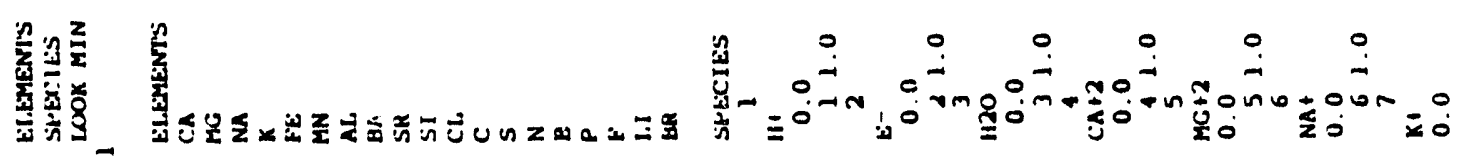




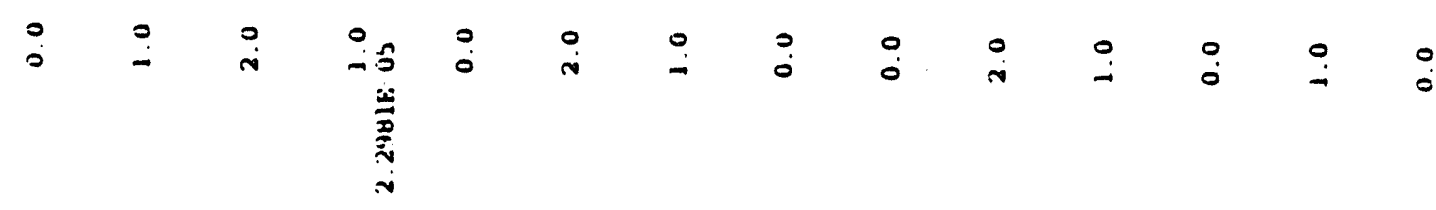

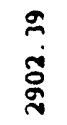

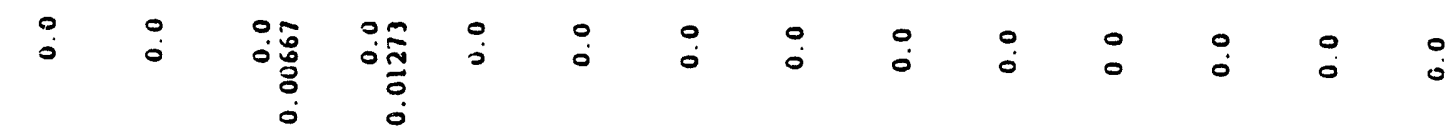

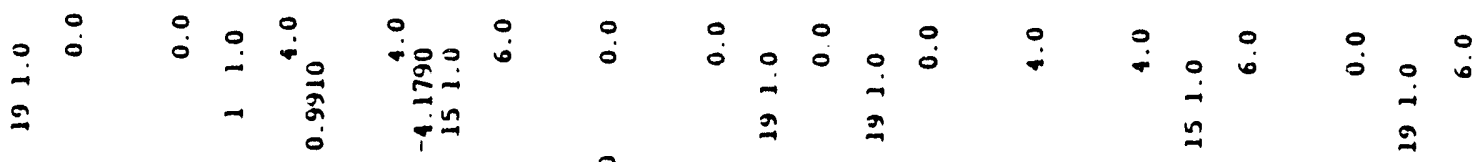

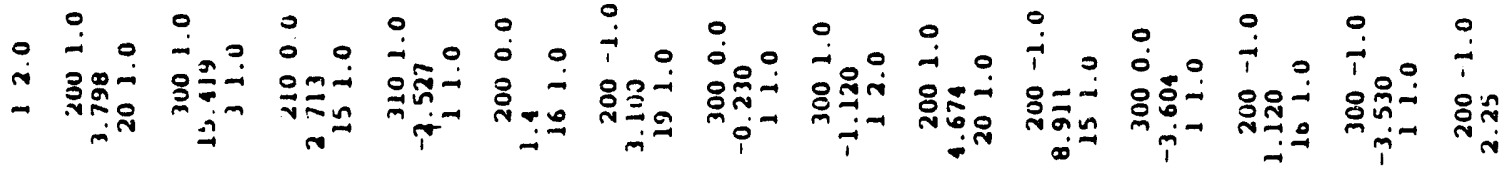

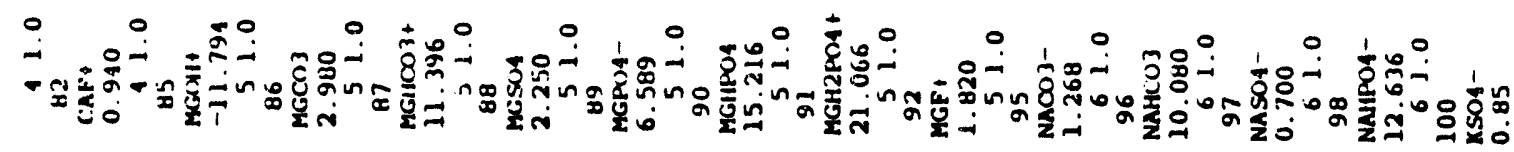

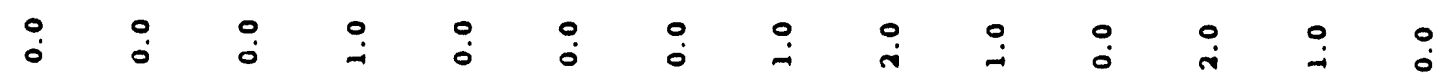

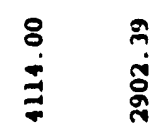

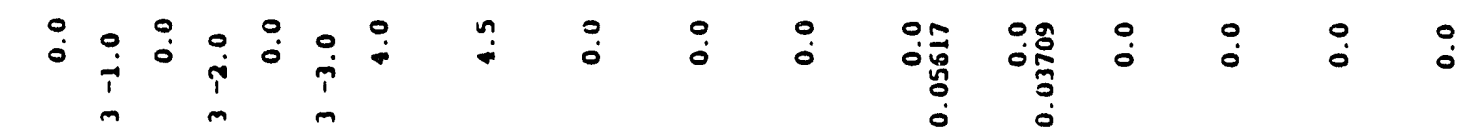

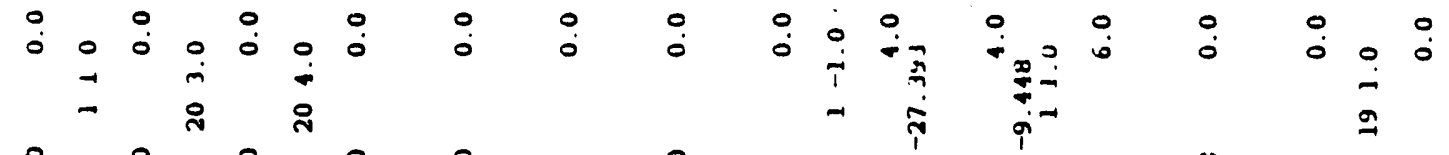

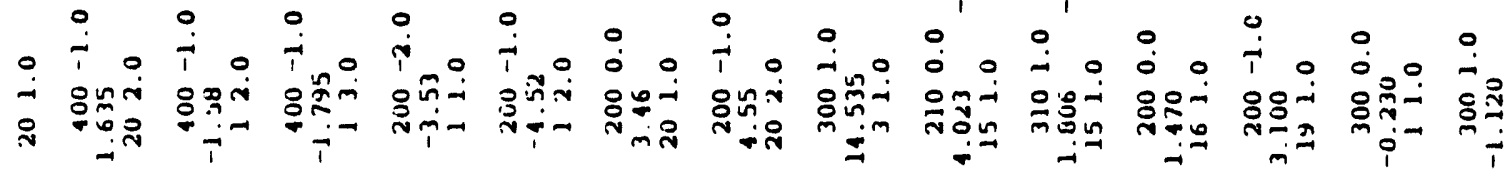

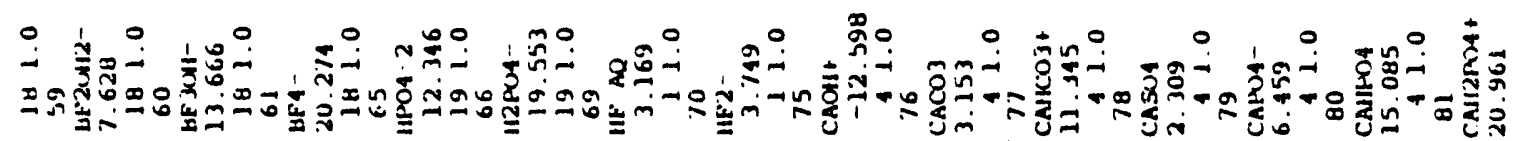




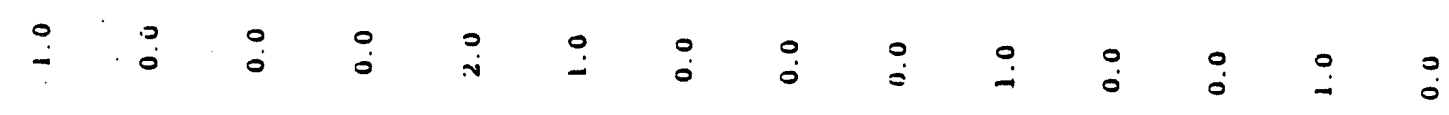

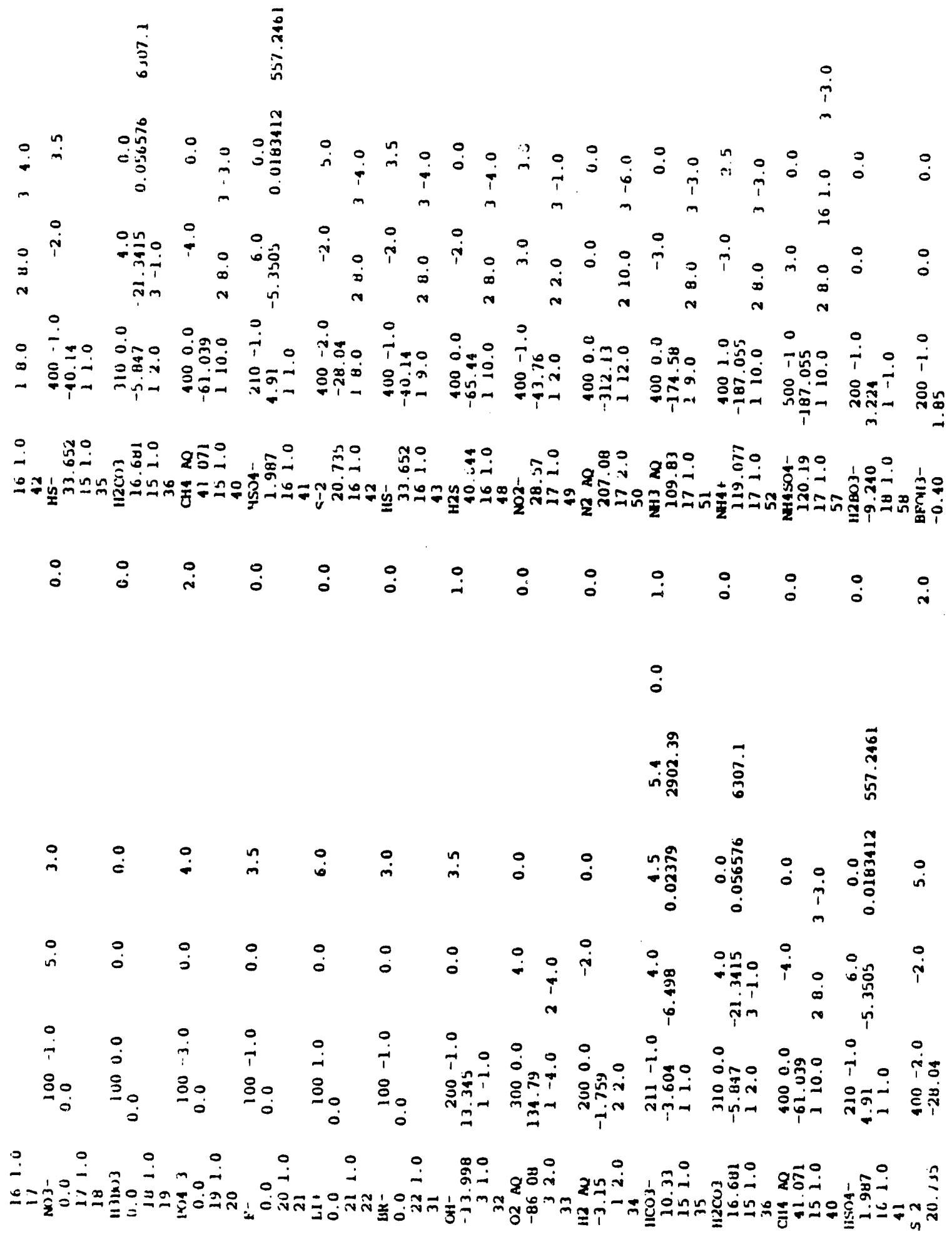


$\begin{array}{llllllllllllll}\dot{j} & 0 & 0 & 0 & 0 & 0 & 0 & 0 & 0 & 0 & 0 & 0 & 0 & 0\end{array}$

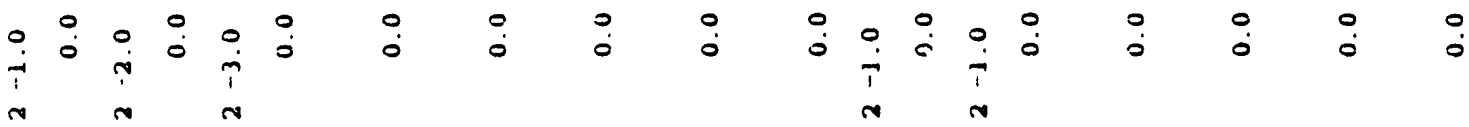

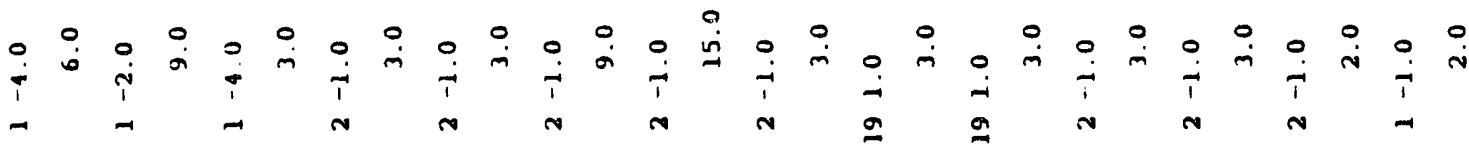

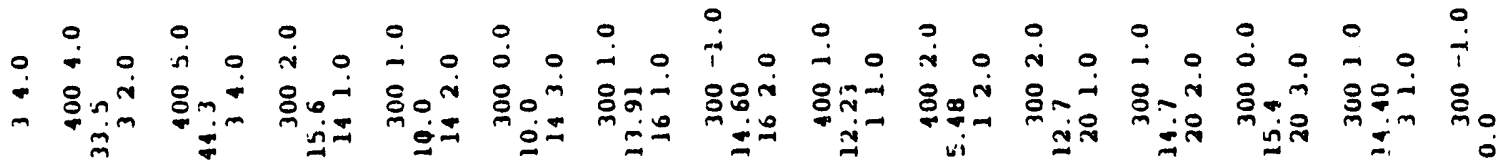

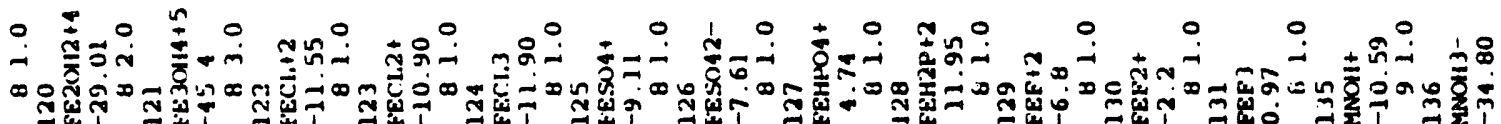

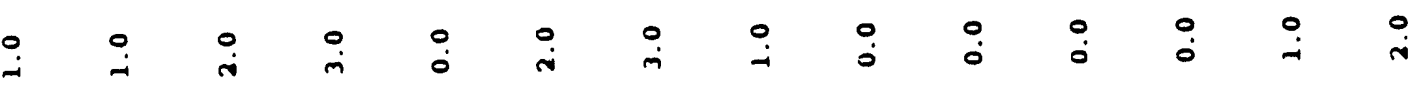

$$
\stackrel{0}{i} \quad \stackrel{0}{i}
$$

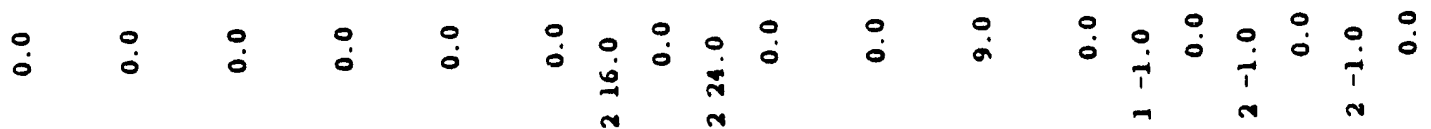

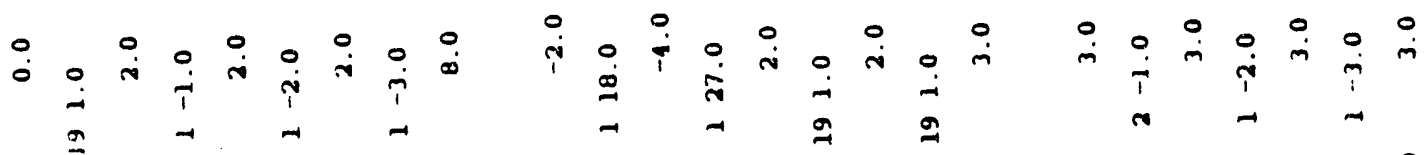

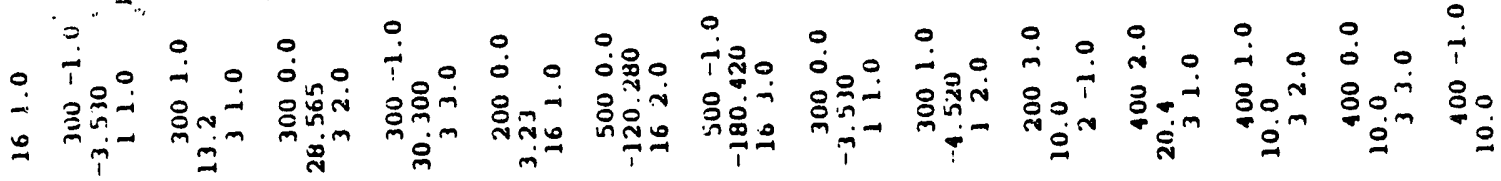

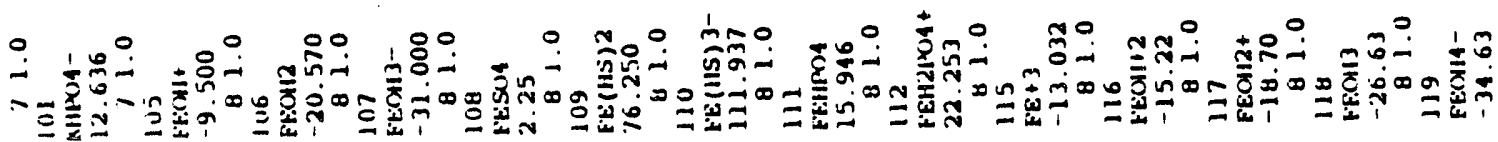




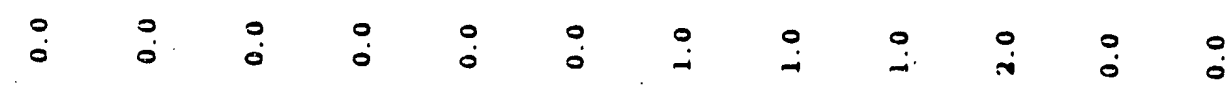

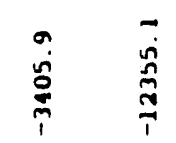

$\rightarrow 0$

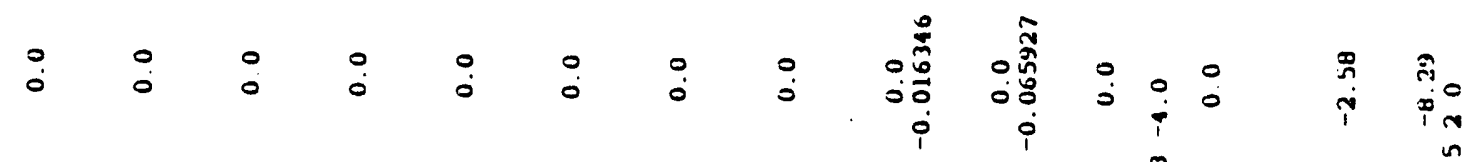

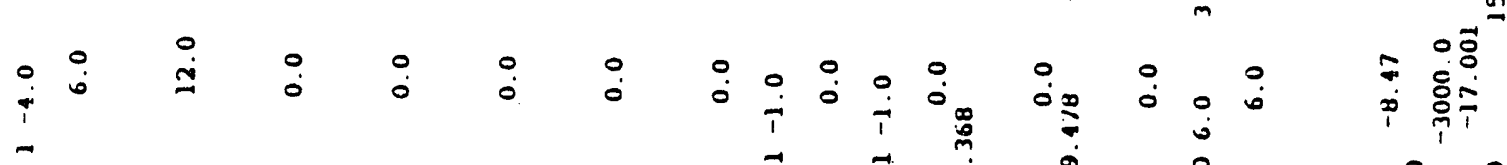

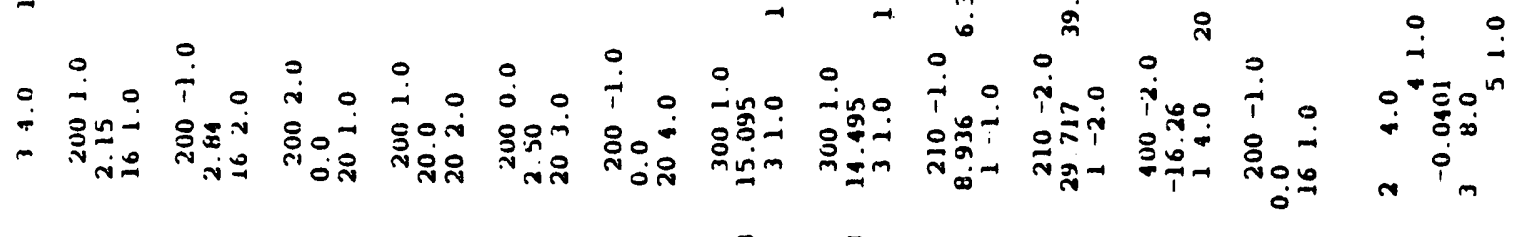

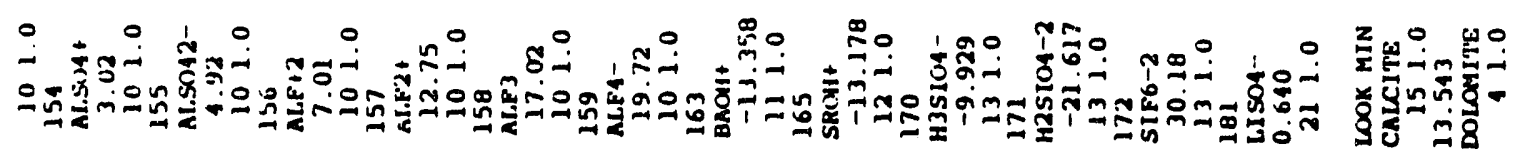

$\begin{array}{llllllllllllll}0 & 0 & 0 & 0 & 0 & 0 & 0 & 0 & 0 & 0 & 0 & 0 & 0 & 0 \\ 0 & 0 & 0 & -i & 0 & 0 & 0 & 0 & 0 & 0 & 0 & 0 & \dot{1} & i\end{array}$

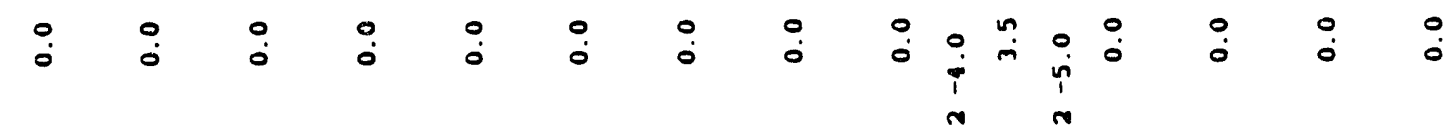

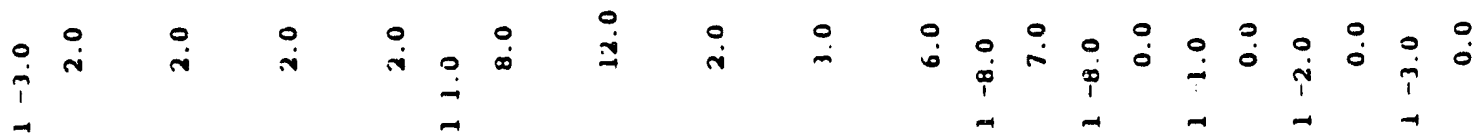

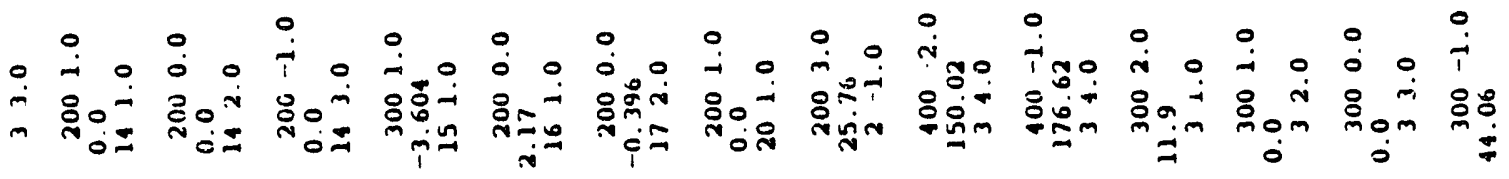

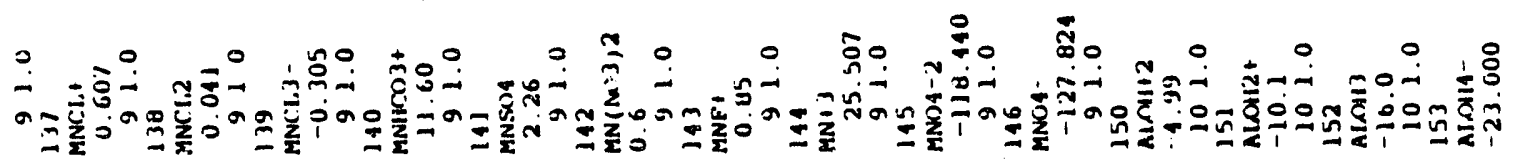




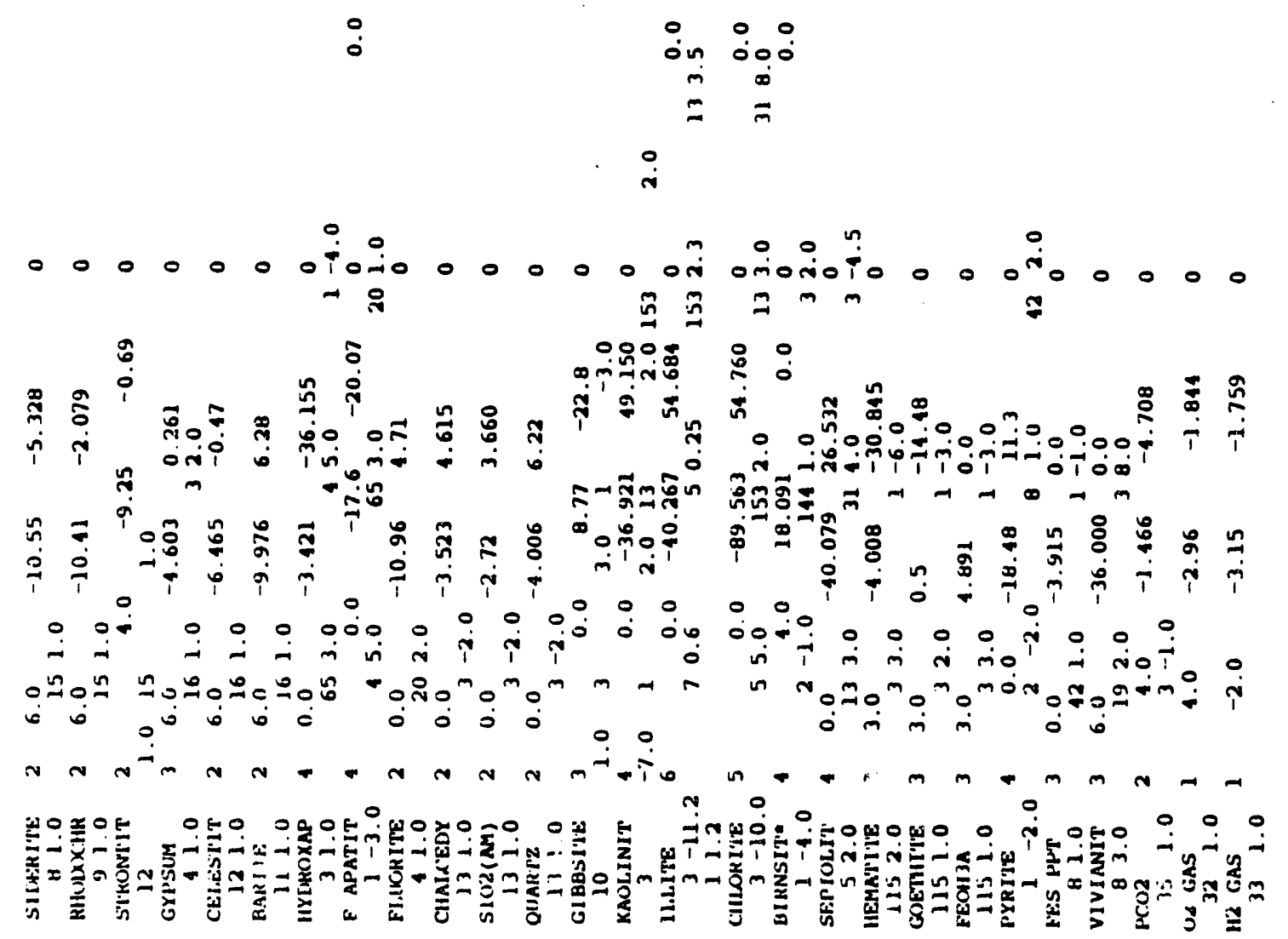




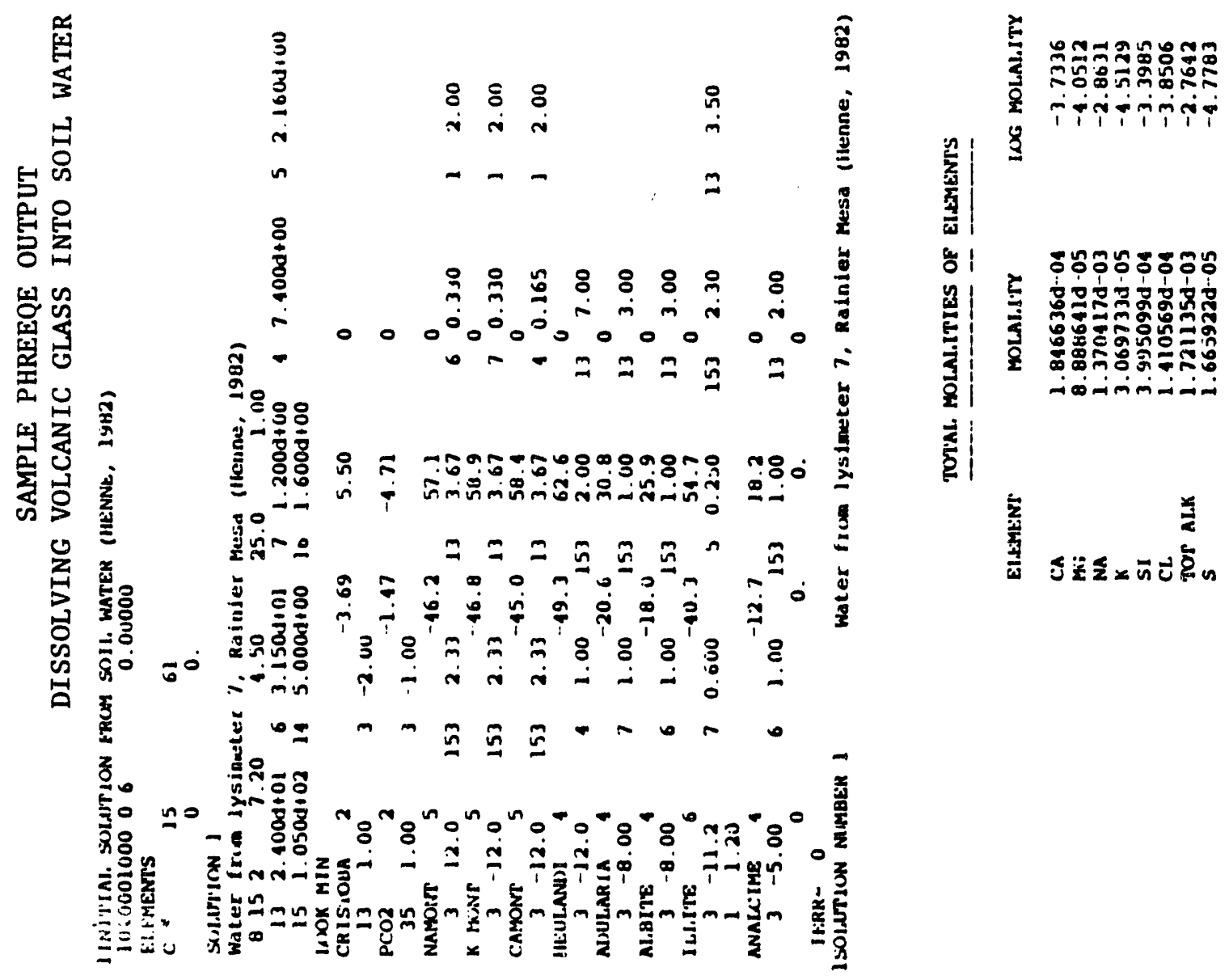


농ํํㅇ

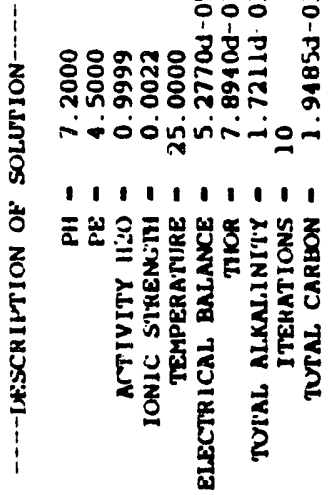

ริำ 3

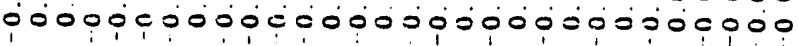

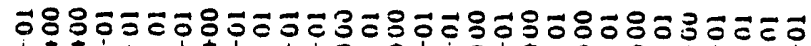

究

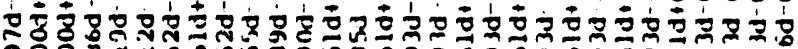

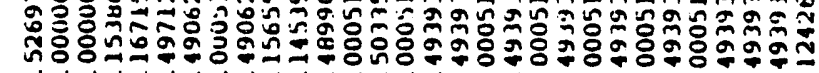
वं-

है $\S$

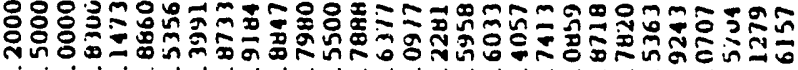

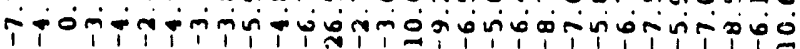

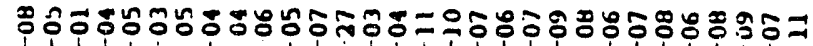

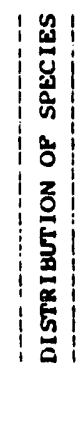

$$
\text { }
$$

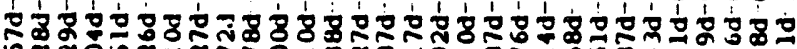

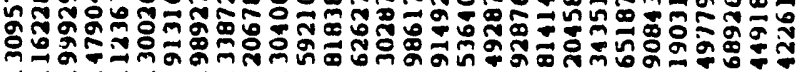

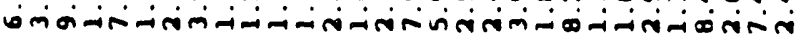

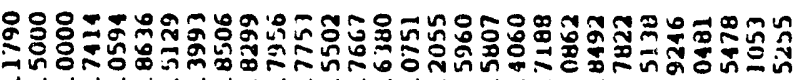

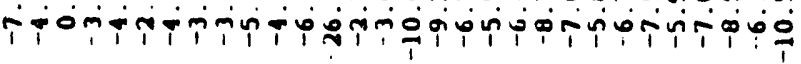

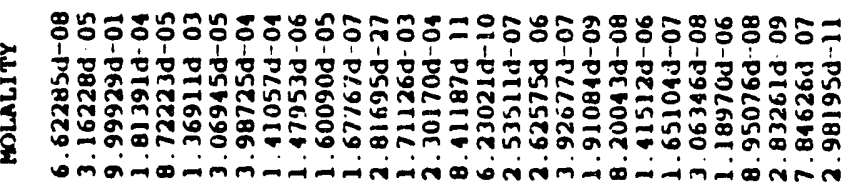

w 000000000000000000000000000000

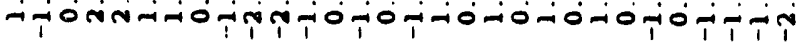
嵌

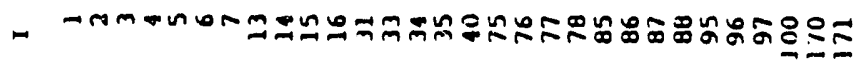



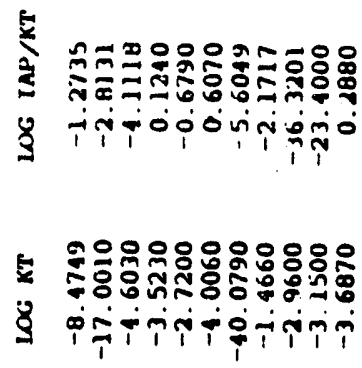

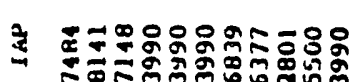

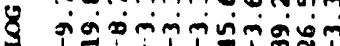

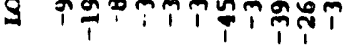

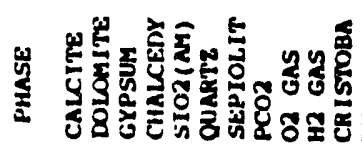

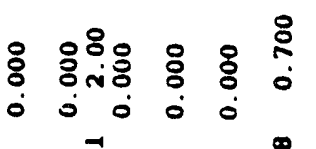

-

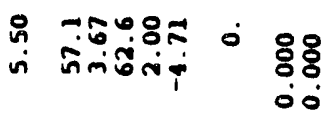

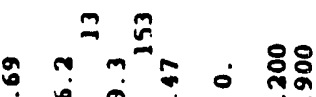

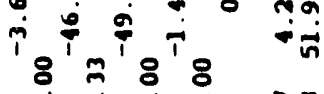
$6^{\circ}$ i $i \dot{i} \mathrm{rm}$

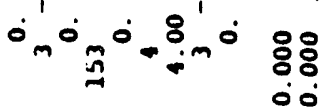

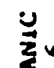
گo no

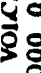

8

:

8

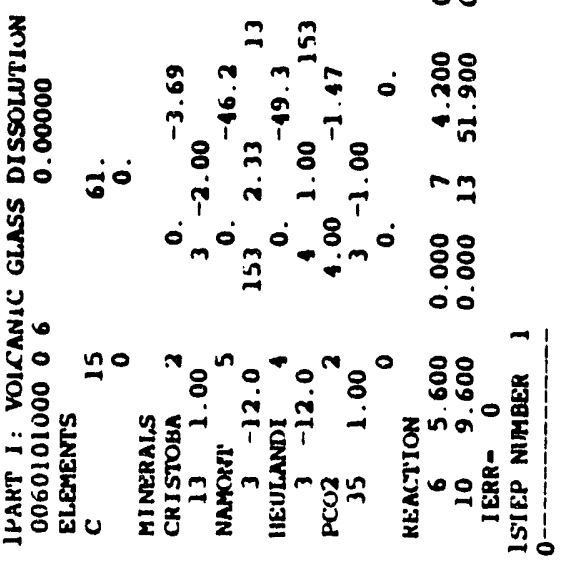

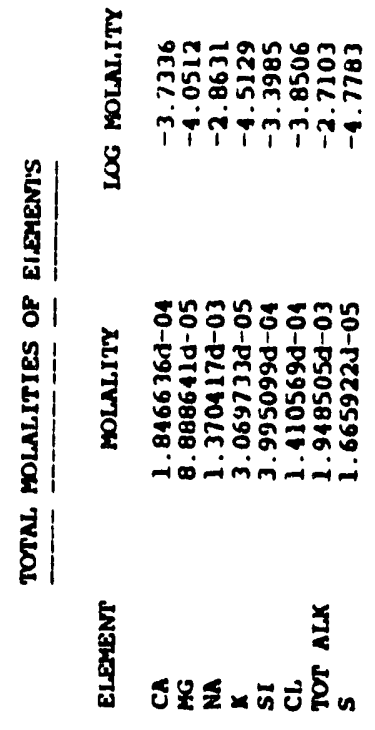




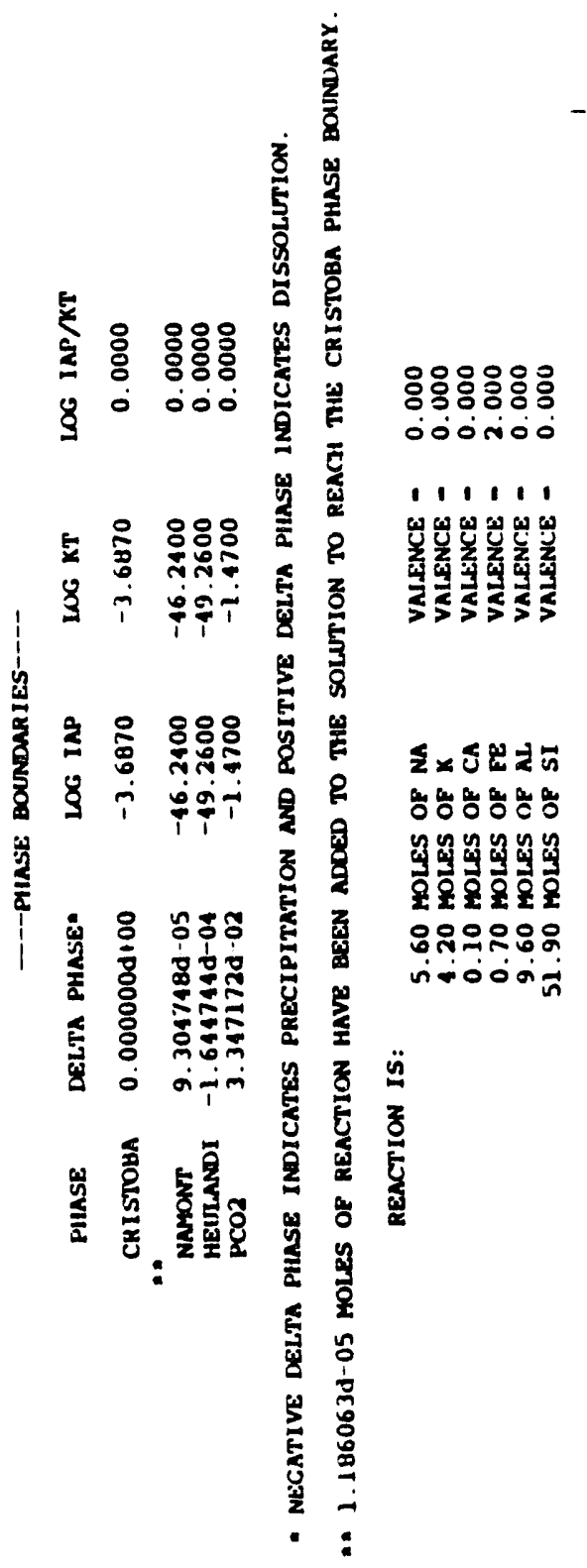

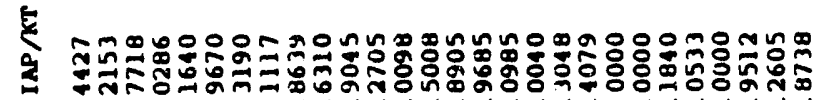

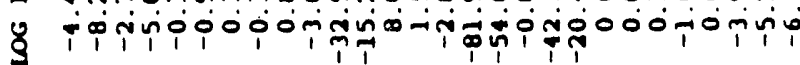

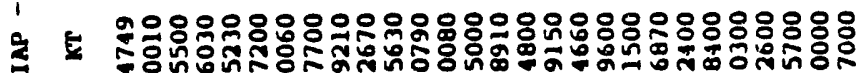

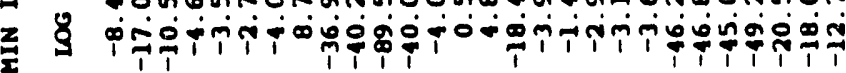

安

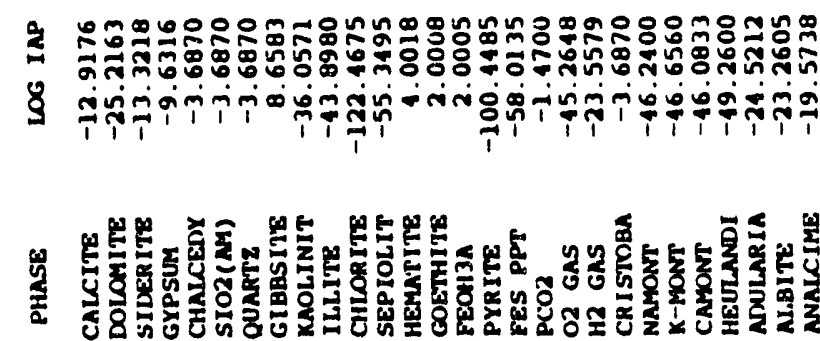



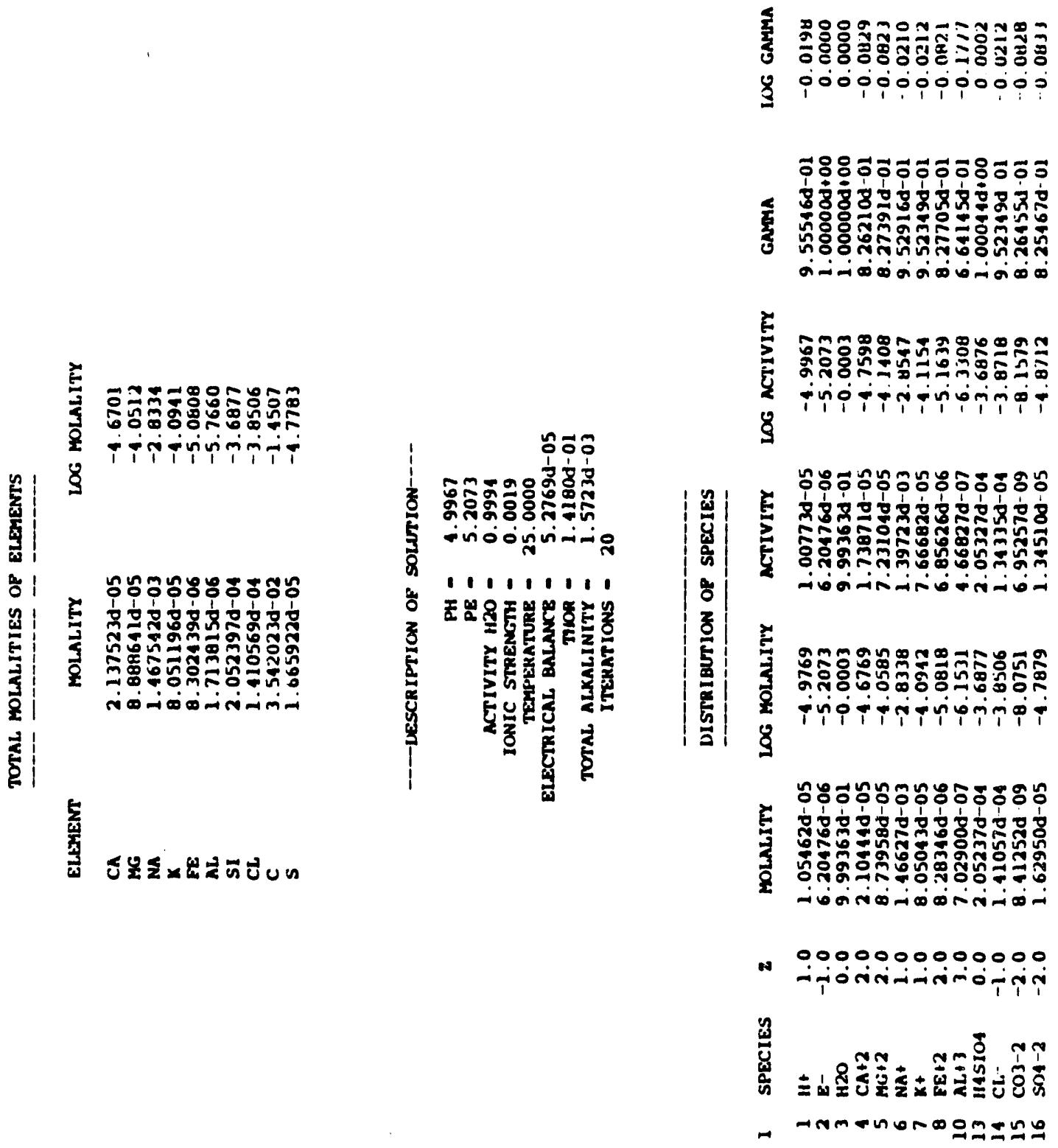


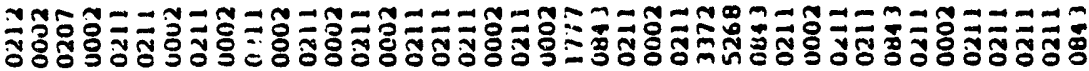
jopopio

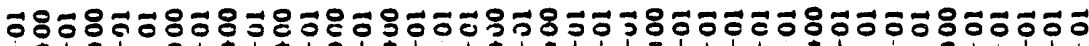

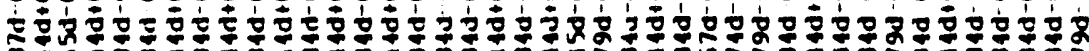

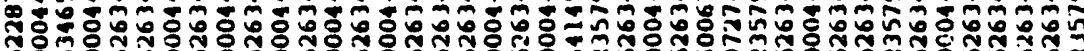

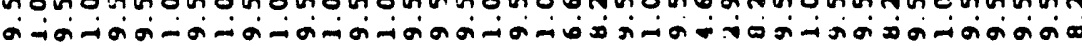

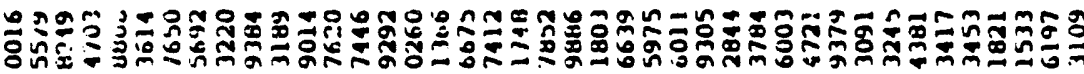

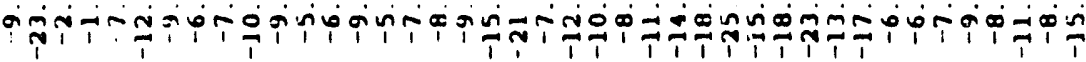

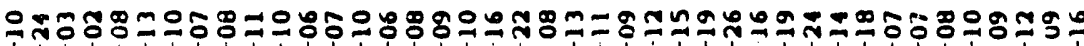

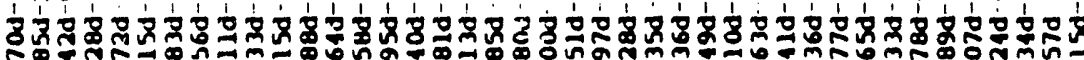

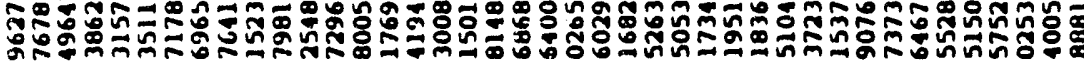

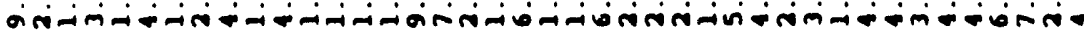

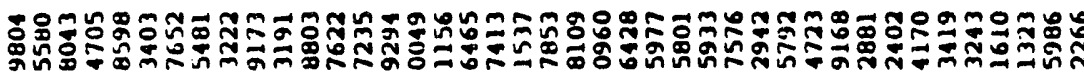

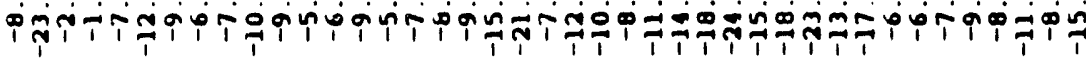

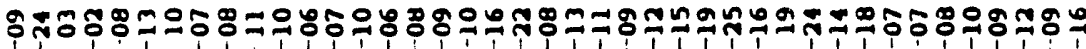

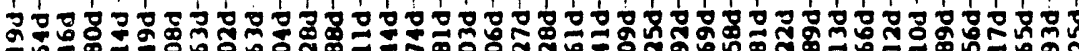

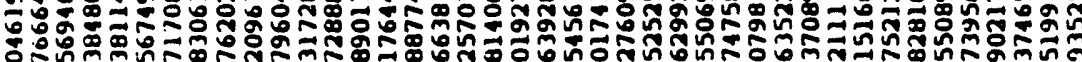
-

00000000000000000000000000000000000000000

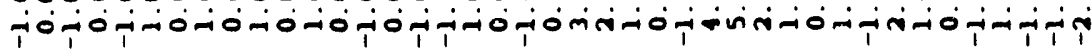

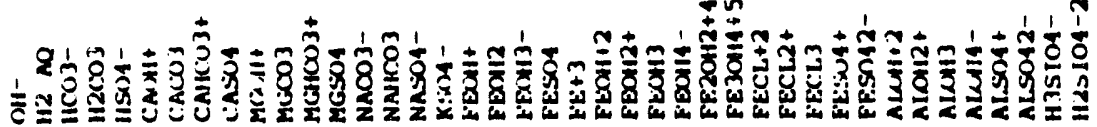

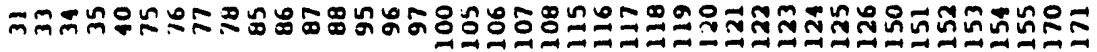



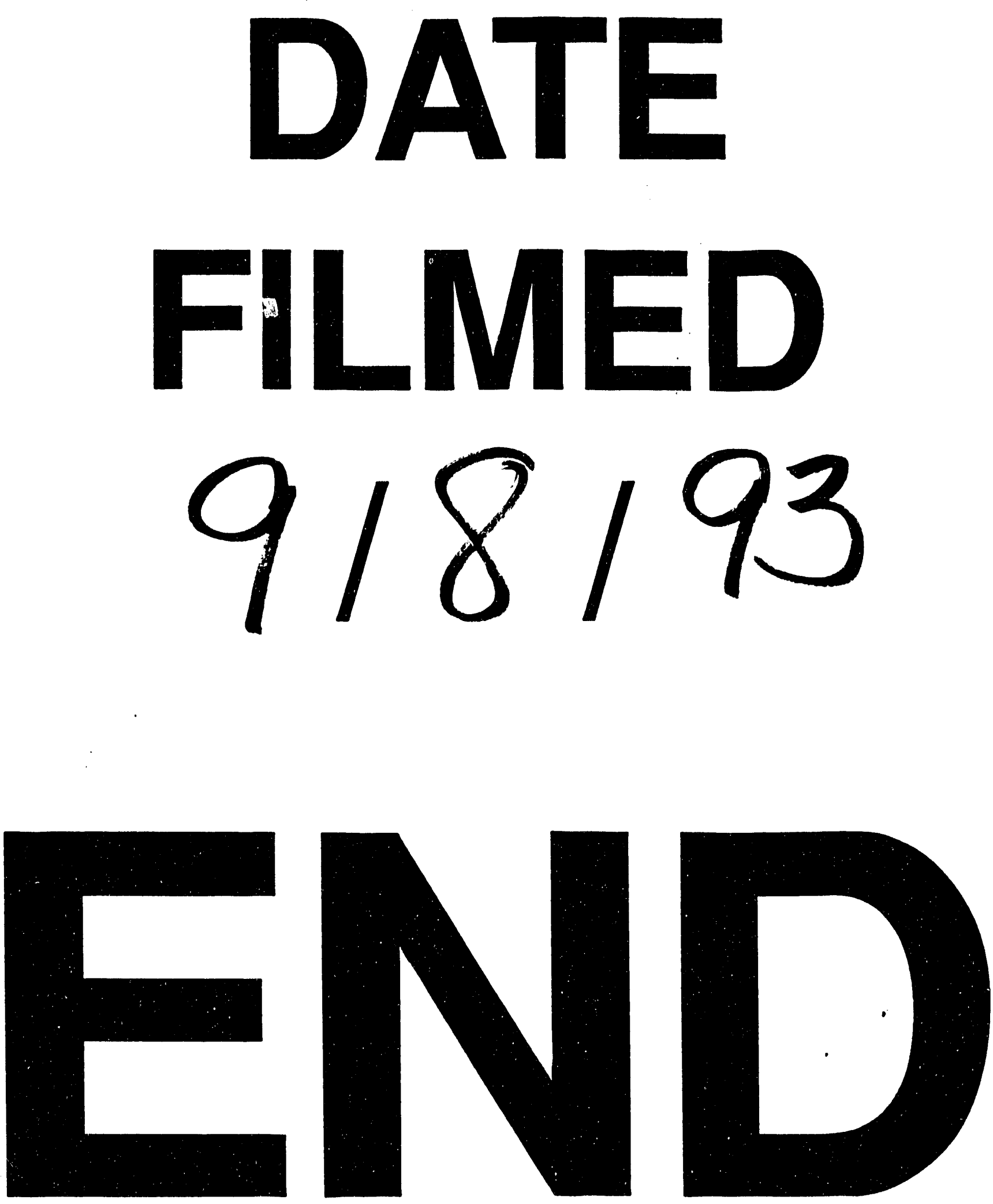
